\title{
Synthesis of Triarylmethanes via Palladium-Catalyzed Suzuki-Miyaura Reactions of Diarylmethyl Esters
}

Amira H. Dardir, ${ }^{\mathrm{a}}$ Irene Casademont-Reig, ${ }^{\mathrm{b}, \mathrm{c}, \mathrm{d}}$ David Balcells, ${ }^{\mathrm{b}, *}$ Jonathan D. Ellefsen, ${ }^{\mathrm{a}}$ Matthew R. Espinosa, ${ }^{a}$ Nilay Hazari, ${ }^{\text {a,* }}$ Nicholas E. Smith ${ }^{\mathrm{a}}$

a'Department of Chemistry, Yale University, P. O. Box 208107, New Haven, Connecticut, 06520,

USA. E-mail: nilay.hazari@yale.edu.

${ }^{b}$ Hylleraas Centre for Quantum Molecular Sciences, Department of Chemistry, University of

Oslo, P.O. Box 1033, Blindern, N-0315 Oslo, Norway. E-mail: david.balcells@ kjemi.uio.no.

'Donostia International Physics Center (DIPC), 20018 Donostia, Euskadi, Spain.

${ }^{\mathrm{d}}$ Kimika Fakultatea, Euskal Herriko Unibertsitatea (UPV/EHU), Donostia, Euskadi, Spain.

\section{Table of Contents}

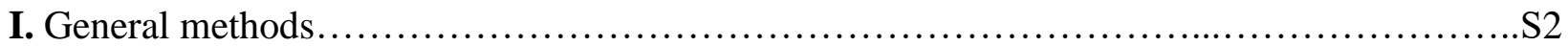

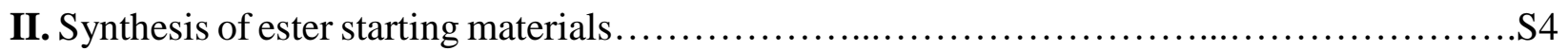

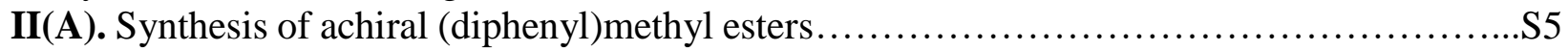

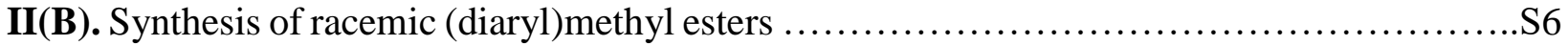

II(C). Synthesis of chiral (diaryl)methyl pentafluorobenzoates.............................. 10

II(D). Synthesis of phenyl benzoate derivatives.......................................... 12

III. Comparison of phenyl and benzyl benzoate in Pd-catalyzed Suzuki-Miyaura reactions......S13

IV. Comparison of (diphenyl)methyl- acetate, benzoate, pentafluorobenzoate, chloride, and

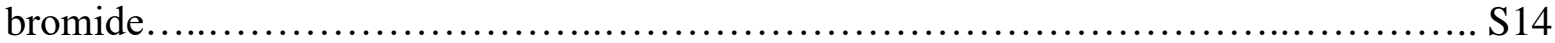

V. Optimization of Pd-catalyzed Suzuki-Miyaura reaction of (diphenyl)methyl pentafluorobenzoate with 4-methoxyphenylboronic acid......................................... 15

VI(A). Substrate scope for Pd-catalyzed Suzuki-Miyaura reactions of (diaryl)methyl pentafluorobenzoate and phenyl boronic acid............................................. 17

VI(B). Substrate scope for stereoselective Pd-catalyzed Suzuki-Miyaura reactions of chiral (diaryl)methyl pentafluorobenzoate and aryl boronic acids.......................S20

VI(C). Substrate scope for Pd-catalyzed Suzuki-Miyaura reactions of (diphenyl)methyl

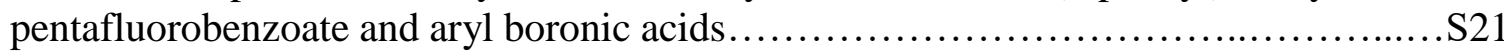

VI(D). Procedure for determination of NMR yields in substrate scopes .................... S25

VI(E). Boronic acids that were not compatible with our reaction.........................S26

VII. Synthesis of oxidative addition complexes from (IPr)Pd(styrene) ${ }_{2}$ and esters.............S27

VIII. Comparing rates of oxidative addition of diphenylmethyl- and (2methylphenyl)(phenyl)methyl-2,3,4,5,6-pentafluorobenzoate...............................S29

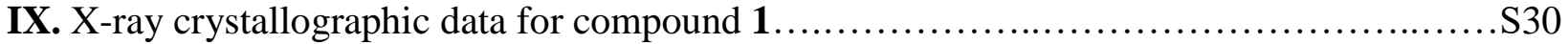

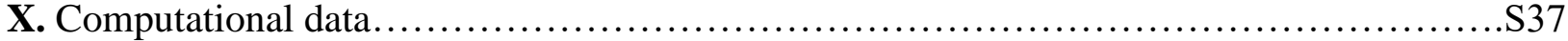

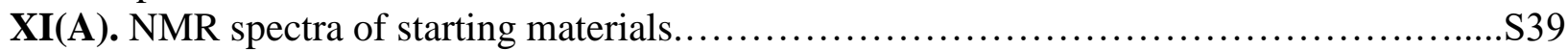

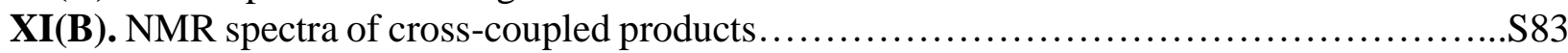

XI(C). NMR spectra of palladium complexes............................................ 118

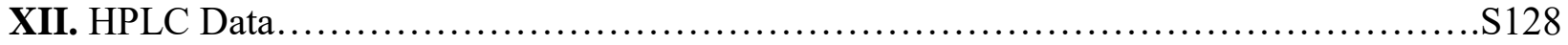

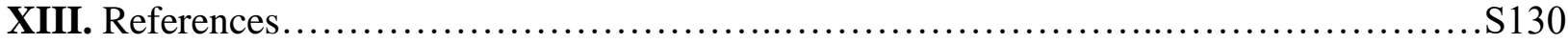




\section{General methods}

General experimental details. Experiments were performed under a dinitrogen atmosphere in an M-Braun glovebox or using standard Schlenk techniques unless otherwise stated. Under standard glovebox conditions purging was not performed between uses of diethyl ether, pentane, benzene, toluene and THF; thus, when any of these solvents were used, traces of all these solvents were in the atmosphere and could be found intermixed in the solvent bottles. Toluene, THF, and 1,4dioxane were dried by passage through a column of activated alumina followed by storage under dinitrogen. $\mathrm{H}_{2} \mathrm{O}, \mathrm{MeOH}, \mathrm{EtOH}$, and ${ }^{\mathrm{i}} \mathrm{PrOH}$ were sparged with dinitrogen for 1 hour and stored under dinitrogen. Room temperature is considered $20-23{ }^{\circ} \mathrm{C}$. All commercial chemicals were used as received except where noted. Ethyl acetate and hexanes were purchased from Fisher Scientific. SIPr, IPr*OMe, and IMes were purchased from Strem Chemicals, Inc. SIPr was stored in a $-35{ }^{\circ} \mathrm{C}$ refrigerator in a dinitrogen-filled glovebox. IPr was synthesized according to a literature procedure. ${ }^{1}$ XPhos and $\mathrm{PCy}_{3}$ were purchased from Sigma-Aldrich and stored in a dinitrogen-filled glovebox. Cesium carbonate $(99+\%)$ was purchased from Strem Chemicals, Inc. Potassium carbonate and sodium carbonate were purchased from Mallinckrodt and finely ground with a mortar and pestle prior to use. Potassium phosphate was purchased from Acros Organics. Bases were oven dried prior to use. Palladium precatalysts, $\left(\eta^{3}-1-{ }^{t} \mathrm{Bu}\right.$-indenyl $) \mathrm{Pd}(\mathrm{L}) \mathrm{Cl}, \quad\left(\eta^{3}-\right.$ cinnamyl) $\mathrm{Pd}(\mathrm{IPr}) \mathrm{Cl}$, and PEPPSI-IPr, were synthesized using previously reported procedures. ${ }^{2}$ Racemic alcohols were synthesized using a modified literature procedure. ${ }^{3}$ Chiral alcohols were synthesized according to a literature procedure. ${ }^{4}$ Diarylmethyl esters and phenyl esters were synthesized according to a literature procedure. ${ }^{5}$

NMR spectra were recorded on Agilent- 400, 500 and $600 \mathrm{MHz}$ spectrometers at ambient probe temperatures unless otherwise stated. NMR solvents were purchased from Cambridge Isotope Laboratories and used without further purification. Chemical shifts are reported with respect to residual internal protio solvent for ${ }^{1} \mathrm{H}$ and ${ }^{13} \mathrm{C}$ NMR spectra. Chemical shifts for other nuclei are referenced through the gyromagnetic ratio method. ${ }^{6}$ Spectral data are reported as follows: chemical shift (multiplicity [singlet (s), broad singlet (br s), doublet (d), triplet (t), quartet (q), multiplet (m), doublet of doublets (dd), etc.], coupling constant, integration). Gas chromatography (GC) analyses were performed on a Shimadzu GC-2010 Plus apparatus equipped with a flame ionization detector and a Shimadzu SHRXI-5MS column ( $30 \mathrm{~m}, 250 \mu \mathrm{m}$ inner diameter, film: $0.25 \mu \mathrm{m})$. The following conditions were utilized for GC analyses: flow rate $1.23 \mathrm{~mL} / \mathrm{min}$ constant flow, column temperature $50{ }^{\circ} \mathrm{C}$ (held for $5 \mathrm{~min}$ ), $20^{\circ} \mathrm{C} / \mathrm{min}$ increase to $300{ }^{\circ} \mathrm{C}$ (held for $5 \mathrm{~min}$ ), total time 22.5 min. High performance liquid chromatography (HPLC) analysis was performed on an Agilent 1100 series instrument equipped with a diode array detector $(\lambda=265 \mathrm{~nm})$ and a chiral column from Daicel Chemical Industries under ambient temperature. High resolution mass spectrometry (HRMS) was performed on a high-resolution Q-tof MS/Acquity UPLC instrument equipped with a BEH C18 column $(1.7 \mu \mathrm{m}$ particle size, $2.1 \times 50 \mathrm{~mm})$ and a photodiode array detector. Optical rotations were recorded on a Rudolph Research Analytical Autopol VI Automatic Polarimeter at the sodium D line (50.0 mm path length) at $20{ }^{\circ} \mathrm{C}$ in $\mathrm{CHCl}_{3}$ with concentration $(c)$ given in $\mathrm{g} / 100$ $\mathrm{mL}$. Infrared (IR) spectra were recorded on a Nicolet 6700 ATR/FT-IR spectrometer with a diamond tip.

Low-temperature diffraction data ( $\omega$-scans) were collected on a Rigaku MicroMax-007HF diffractometer coupled to a Dectris Pilatus3R detector with Mo $\mathrm{K} \alpha(\lambda=0.71073 \AA)$ for the 
structure of $\mathbf{1}$. The diffraction images were processed and scaled using Rigaku Oxford Diffraction software (CrysAlisPro; Rigaku OD: The Woodlands, TX, 2015). The structure was solved with SHELXT and was refined against F2 on all data by full-matrix least squares with SHELXL (Sheldrick, G. M. Acta Cryst. 2008, A64, 112-122). All non-hydrogen atoms were refined anisotropically. Hydrogen atoms were included in the model at geometrically calculated positions and refined using a riding model. The isotropic displacement parameters of all hydrogen atoms were fixed to 1.2 times the $\mathrm{U}$ value of the atoms to which they are linked (1.5 times for methyl groups). Residual electron density due to solvent of crystallization (pentane) could not be adequately refined using a disordered atom site model and as a result the electron density was modelled using the SQUEEZE function. The full numbering scheme of compound $\mathbf{1}$ can be found in the full details of the X-ray structure determination (CIF), which is included as Supporting Information. CCDC number 2045209 (compound 1) contains the supplementary crystallographic data for this paper. These data can be obtained free of charge from The Cambridge Crystallographic Data Center via www.ccdc.cam.ac.uk/data_request/cif. 


\section{Synthesis of ester starting materials}

The following general procedure (A) was used to synthesize esters unless otherwise stated: Carboxylic acid (1 equiv.), alcohol (1 equiv.), $N$-(3-Dimethylaminopropyl)- $N$ '-ethylcarbodiimide hydrochloride $(\mathrm{EDC} \cdot \mathrm{HCl})$ (1.1 equiv.), 4-dimethylaminopyridine (DMAP) (0.25 equiv.), and DCM were added to a 100 or $250 \mathrm{~mL}$ round bottom flask equipped with a magnetic stir bar. The solution was sparged with dinitrogen and stirred at room temperature for $18 \mathrm{~h}$. After the reaction was complete, the reaction was quenched with aqueous sodium bicarbonate in a separatory funnel. The aqueous layer was extracted three times with DCM $(10 \mathrm{~mL})$ and the combined organic layers were washed with concentrated aqueous ammonium chloride $(15 \mathrm{~mL})$ followed by concentrated aqueous sodium chloride $(15 \mathrm{~mL})$. The organic layer was dried over sodium sulfate or magnesium sulfate, filtered, and concentrated. Purification was performed using normal-phase column chromatography to provide the pure products in the reported yields.

The following general procedure (B) was used to synthesize esters unless otherwise stated: Acyl chloride (1 equiv.), alcohol (1 equiv.), DMAP (0.05 equiv.), trimethylamine (1.2 equiv.), and DCM were added to a 100 or $250 \mathrm{~mL}$ round bottom flask equipped with a magnetic stir bar. The solution was sparged with dinitrogen and stirred at room temperature for $18 \mathrm{~h}$. After the reaction was complete, the reaction was quenched with aqueous sodium bicarbonate in a separatory funnel. The aqueous layer was extracted three times with DCM $(10 \mathrm{~mL})$ and the combined organic layers were washed with concentrated aqueous ammonium chloride $(15 \mathrm{~mL})$ followed by concentrated aqueous sodium chloride $(15 \mathrm{~mL})$. The organic layer was dried over sodium sulfate or magnesium sulfate, filtered, and concentrated. Purification was performed using normal-phase column chromatography to provide the pure products in the reported yields. 


\section{II(A). Synthesis of achiral (diphenyl)methyl esters}<smiles>O=C(OC(c1ccccc1)c1ccccc1)c1c(F)c(F)c(F)c(F)c1F</smiles>

(Diphenyl)methyl 2,3,4,5,6-pentafluorobenzoate. Following general procedure (A), a mixture of 2,3,4,5,6-pentafluorobenzoic acid (5.00 g, $0.0236 \mathrm{~mol})$, diphenylmethanol $(4.350 \mathrm{~g}, 0.02360 \mathrm{~mol}), \mathrm{EDC} \cdot \mathrm{HCl}$ (4.970 g, $0.02590 \mathrm{~mol})$, and DMAP $(0.720 \mathrm{~g}, 0.00589 \mathrm{~mol})$ in DCM $(50 \mathrm{~mL})$ were stirred at room temperature for $18 \mathrm{~h}$. Purification was performed using silica column chromatography with a 1\% EtOAc/99\% petroleum ether (PE) solvent mixture to provide a white solid. Following purification, a $42 \%$ yield (3.76 g) was obtained. ${ }^{1} \mathrm{H}$ and ${ }^{13} \mathrm{C}$ NMR data were consistent with that published in the literature. ${ }^{7}$<smiles>O=C(OC(c1ccccc1)c1ccccc1)c1ccccc1</smiles>

(Diphenyl)methyl benzoate. Following general procedure (A), a mixture of benzoic acid $(0.489 \mathrm{~g}, 0.00814 \mathrm{~mol})$, diphenylmethanol $(1.500 \mathrm{~g}$, $0.008140 \mathrm{~mol}), \mathrm{EDC} \cdot \mathrm{HCl}(1.720 \mathrm{~g}, 0.008950 \mathrm{~mol})$, and DMAP $(0.249 \mathrm{~g}$, $0.00204 \mathrm{~mol})$ in DCM $(15 \mathrm{~mL})$ were stirred at room temperature for $18 \mathrm{~h}$. Purification was performed using silica column chromatography with a gradient of $100 \%$ hexanes to $10 \%$ EtOAc/90\% hexanes solvent mixture to provide a white solid. Following purification, a $48 \%$ yield $(0.887 \mathrm{~g})$ was obtained. ${ }^{1} \mathrm{H}$ and ${ }^{13} \mathrm{C}$ NMR data were consistent with that published in the literature. ${ }^{8}$<smiles>CC(=O)OC(c1ccccc1)c1ccccc1</smiles>

(Diphenyl)methyl acetate. Following general procedure (A), a mixture of acetic acid $(238 \mu \mathrm{L}, 4.16 \mathrm{mmol})$, diphenylmethanol $(0.767 \mathrm{~g}, 4.16 \mathrm{mmol})$, $\mathrm{EDC} \cdot \mathrm{HCl}(0.878 \mathrm{~g}, 4.580 \mathrm{mmol})$, and DMAP $(0.127 \mathrm{~g}, 1.04 \mathrm{mmol})$ in DCM $(10 \mathrm{~mL})$ were stirred at room temperature for $18 \mathrm{~h}$. Purification was performed using silica column chromatography with a 10\% EtOAc/90\% PE solvent mixture to provide a colorless solid. Following purification, a $20 \%$ yield $(0.190$

g) was obtained. ${ }^{1} \mathrm{H}$ and ${ }^{13} \mathrm{C}$ NMR data were consistent with that published in the literature. ${ }^{9}$ 


\section{II(B). Synthesis of racemic (diaryl)methyl esters pentafluorobenzoates}

General Note: C-F coupling makes the assignment of ${ }^{13} \mathrm{C}\left\{{ }^{1} \mathrm{H}\right\}$ spectra containing the pentafluorophenyl group challenging. We have reported all of the peaks that are observed in the spectra, even though some of them are caused by C-F coupling and are associated with the same carbon atom.

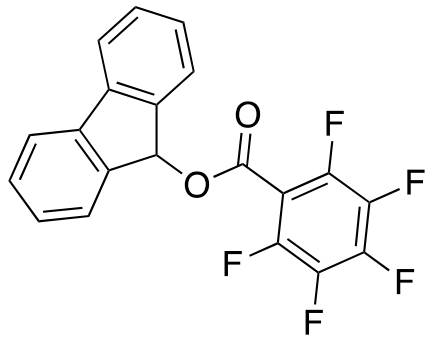

$\mathrm{Hz}, 2 \mathrm{H}), 7.64(\mathrm{~d}, J=7.49 \mathrm{~Hz}, 2 \mathrm{H}), 7.45(\mathrm{t}, J=8.46 \mathrm{~Hz}, 2 \mathrm{H}), 7.34(\mathrm{t}, J=6.47 \mathrm{~Hz}, 2 \mathrm{H}), 7.02 \mathrm{ppm}$ (s, $1 \mathrm{H}) .{ }^{13} \mathrm{C}\left\{{ }^{1} \mathrm{H}\right\}$ NMR $\left(\mathrm{CDCl}_{3}, 151 \mathrm{MHz}\right): 160.17,146.28,144.53,144.29,142.57,141.32$, $140.89,138.66,136.98,130.15,128.25,126.16,120.35,108.37,77.67$ ppm. ${ }^{19} \mathrm{~F} \mathrm{NMR}\left(\mathrm{CDCl}_{3}\right.$, $376 \mathrm{MHz}):-137.84(\mathrm{~m}, 2 \mathrm{~F}),-148.18(\mathrm{t}, J=20.88 \mathrm{~Hz}, 1 \mathrm{~F}),-160.12 \mathrm{ppm}(\mathrm{m}, 2 \mathrm{~F})$. HRMS $\left(\mathrm{ESI}^{+}\right)$: $376.0519[\mathrm{M}]^{+}$. Calcd for $\left[\mathrm{C}_{20} \mathrm{H}_{9} \mathrm{~F}_{5} \mathrm{O}_{2}\right]: 376.0523$.<smiles>COc1ccc(C(OC(=O)c2c(F)c(F)c(F)c(F)c2F)c2ccccc2)cc1</smiles>

(4-methoxyphenyl)(phenyl)methyl

$2,3,4,5,6-$ pentafluorobenzoate. Following general procedure (A), a mixture of 2,3,4,5,6-pentafluorobenzoic acid $(0.500 \mathrm{~g}, 2.36$ mmol), (4-methoxyphenyl)(phenyl)methanol $(0.505 \mathrm{~g}, 2.36$ $\mathrm{mmol}), \mathrm{EDC} \cdot \mathrm{HCl}(0.497 \mathrm{~g}, 2.59 \mathrm{mmol})$, and DMAP $(0.072 \mathrm{~g}$, $0.59 \mathrm{mmol})$ in DCM $(10 \mathrm{~mL})$ were stirred at room temperature for $18 \mathrm{~h}$. Purification was performed using silica column chromatography with a $10 \%$ EtOAc/90\% hexanes solvent mixture to provide a white solid. Following purification, a $33 \%$ yield $(0.315 \mathrm{~g})$ was obtained. ${ }^{1} \mathrm{H}$ and ${ }^{13} \mathrm{C}$ NMR data were consistent with that published in the literature. ${ }^{10}$<smiles>O=C(OC(c1ccccc1)c1ccc(C(F)(F)F)cc1)c1c(F)c(F)c(F)c(F)c1F</smiles>

(4-trifluoromethylphenyl)(phenyl)methyl

$2,3,4,5,6-$ pentafluorobenzoate. Following general procedure (A), a mixture of 2,3,4,5,6-pentafluorobenzoic acid $(0.500 \mathrm{~g}, 2.36$ mmol), (4-trifluoromethylphenyl)(phenyl)methanol (0.595 g, $2.36 \mathrm{mmol}), \mathrm{EDC} \cdot \mathrm{HCl}(0.497 \mathrm{~g}, 2.59 \mathrm{mmol})$, and DMAP $(0.072$ $\mathrm{g}, 0.59 \mathrm{mmol})$ in DCM $(10 \mathrm{~mL})$ were stirred at room temperature for $18 \mathrm{~h}$. Purification was performed using silica column chromatography with a 5\% EtOAc/95\% hexanes solvent mixture to provide a colorless oil. Following purification, a $61 \%$ yield $(0.642 \mathrm{~g})$ was obtained. ${ }^{1} \mathrm{H}$ NMR $\left(\mathrm{CDCl}_{3}, 600 \mathrm{MHz}\right): 7.65$ (d, $J=8.22 \mathrm{~Hz}, 2 \mathrm{H}), 7.56(\mathrm{~d}, J=8.21 \mathrm{~Hz}, 2 \mathrm{H}), 7.41-7.35(\mathrm{~m}, 5 \mathrm{H}), 7.14 \mathrm{ppm}(\mathrm{s}, 1 \mathrm{H}) .{ }^{13} \mathrm{C}\left\{{ }^{1} \mathrm{H}\right\} \mathrm{NMR}$ $\left(\mathrm{CDCl}_{3}, 151 \mathrm{MHz}\right): 158.16,143.03,138.32,130.67\left(\mathrm{q}, \mathrm{J}_{\mathrm{C}-\mathrm{F}}=33.2 \mathrm{~Hz}\right), 129.05,128.95,127.44$, 127.34, 126.77, 125.89, 124.93, 122.86, 79.08 ppm. $\left.{ }^{19} \mathrm{~F} \mathrm{NMR} \mathrm{(CDCl} 3,376 \mathrm{MHz}\right):-62.74$ (s, 3F), $-137.32(\mathrm{~m}, 2 \mathrm{~F}),-147.39(\mathrm{t}, J=20.60 \mathrm{~Hz}, 1 \mathrm{~F}),-159.93 \mathrm{ppm}(\mathrm{m}, 2 \mathrm{~F})$. This compound did not ionize well enough to acquire HRMS data. 
<smiles>N#Cc1ccc(C(OC(=O)c2c(F)c(F)c(F)c(F)c2F)c2ccc(C#N)cc2)cc1</smiles>

Bis(4-cyanophenyl)methyl

2,3,4,5,6-pentafluorobenzoate.

Following general procedure (A), a mixture of 2,3,4,5,6pentafluorobenzoic acid $(0.500 \mathrm{~g}, 2.36 \mathrm{mmol})$, bis(4cyanophenyl)methanol (0.552 g, $2.36 \mathrm{mmol}), \mathrm{EDC} \cdot \mathrm{HCl}(0.497$ $\mathrm{mg}, 2.59 \mathrm{mmol})$, and DMAP (0.072 g, $0.59 \mathrm{mmol})$ in DCM (10 $\mathrm{mL})$ were stirred at room temperature for $18 \mathrm{~h}$. Purification was performed using silica column chromatography with a $30 \%$ EtOAc/70\% PE solvent mixture to provide a white solid. Following purification, a $40 \%$ yield $(0.399 \mathrm{~g})$ was obtained. ${ }^{1} \mathrm{H}$ NMR $\left(\mathrm{CDCl}_{3}, 600 \mathrm{MHz}\right): 7.70(\mathrm{~d}, J=8.31 \mathrm{~Hz}, 4 \mathrm{H}), 7.53(\mathrm{~d}, J=8.16 \mathrm{~Hz}, 4 \mathrm{H}), 7.11 \mathrm{ppm}(\mathrm{s}, 1 \mathrm{H})$. ${ }^{13} \mathrm{C}\left\{{ }^{1} \mathrm{H}\right\} \mathrm{NMR}\left(\mathrm{CDCl}_{3}, 151 \mathrm{MHz}\right): 157.90,142.84,133.01,127.85,118.18,113.17,77.81 .{ }^{19} \mathrm{~F}$ NMR (CDCl 3 , $376 \mathrm{MHz})$ : -136.98 (m, 2F), -145.98 (t, $J=20.91 \mathrm{~Hz}, 1 \mathrm{~F}),-159.30$ ppm (m, 2F). This compound did not ionize well enough to acquire HRMS data.<smiles>Cc1ccccc1C(OC(=O)c1c(F)c(F)c(F)c(F)c1F)c1ccccc1</smiles>
(2-methylphenyl)(phenyl)methyl

2,3,4,5,6-pentafluorobenzoate. Following general procedure (A), a mixture of 2,3,4,5,6pentafluorobenzoic acid $(0.450 \quad \mathrm{~g}, \quad 2.12 \quad \mathrm{mmol}), \quad$ (2methylphenyl)(phenyl)methanol $(0.420 \mathrm{~g}, 2.12 \mathrm{mmol}), \mathrm{EDC} \cdot \mathrm{HCl}$ (0.449 mg, $2.34 \mathrm{mmol})$, and DMAP (0.065 g, $0.53 \mathrm{mmol})$ in DCM (10 $\mathrm{mL})$ were stirred at room temperature for $18 \mathrm{~h}$. Purification was performed using silica column chromatography with a $5 \%$ EtOAc/95\% hexane solvent mixture to provide a colorless oil. Following purification, a $55 \%$ yield $(0.461 \mathrm{~g})$ was obtained. ${ }^{1} \mathrm{H} \mathrm{NMR}\left(\mathrm{CDCl}_{3}, 600 \mathrm{MHz}\right)$ : 7.46-7.45 (m, 1H), 7.34-7.30 (m, 4H), 7.28-7.26 (m obstructed by solvent, $1 \mathrm{H}), 7.22-7.20(\mathrm{~m}, 2 \mathrm{H}), 7.15-5.14(\mathrm{~m}, 1 \mathrm{H}), 2.31 \mathrm{ppm}(\mathrm{s}, 3 \mathrm{H}) .{ }^{13} \mathrm{C}\left\{{ }^{1} \mathrm{H}\right\}$ NMR ( $\left.\mathrm{CDCl}_{3}, 151 \mathrm{MHz}\right): 158.32,146.61,144.93,144.31,142.59,138.72,138.27,137.03,135.83$, 130.90, 128.77, 128.32, 127.77, 127.09, 126.45, 77.25 ppm. ${ }^{19} \mathrm{~F} \mathrm{NMR}\left(\mathrm{CDCl}_{3}, 376 \mathrm{MHz}\right):-137.55$ $(\mathrm{m}, 2 \mathrm{~F}),-148.17(\mathrm{t}, J=20.94 \mathrm{~Hz}, 1 \mathrm{~F}),-160.20 \mathrm{ppm}(\mathrm{m}, 2 \mathrm{~F})$. This compound did not ionize well enough to acquire HRMS data.<smiles>O=C(OC(c1ccccc1)c1cccc2ccccc12)c1c(F)c(F)c(F)c(F)c1F</smiles>

(1-naphthyl)(phenyl)methyl 2,3,4,5,6-pentafluorobenzoate.

Phenylmagnesium bromide (3 M in diethyl ether, $2.60 \mathrm{~mL}, 7.68 \mathrm{mmol}$ ) was added to a solution of 1-naphthyl aldehyde $(1.000 \mathrm{~g}, 6.400 \mathrm{mmol})$ in THF $(50 \mathrm{~mL})$ at $0{ }^{\circ} \mathrm{C}$ in a $100 \mathrm{~mL}$ Schlenk flask under a dinitrogen atmosphere. The reaction was warmed to room temperature and stirred for $18 \mathrm{~h}$. At this time, the reaction was quenched with aqueous ammonium chloride $(15 \mathrm{~mL})$. The aqueous layer was extracted three times with EtOAc $(10 \mathrm{~mL})$ and the combined organic layers were washed with concentrated aqueous sodium chloride $(15 \mathrm{~mL})$. The organic layer was dried over sodium sulfate, filtered, and concentrated to provide (1-naphthyl)(phenyl)methanol, which was used as is for the synthesis of (1-naphthyl)(phenyl)methyl 2,3,4,5,6-pentafluorobenzoate. Following general procedure $(\mathbf{B})$, a mixture of $2,3,4,5,6$-pentafluorobenzoyl chloride $(313 \mu \mathrm{L}$, $2.17 \mathrm{mmol}$ ), (1-naphthyl)(phenyl)methanol (0.508 g, $2.17 \mathrm{mmol}$ ), DMAP (13.2 mg, $0.108 \mathrm{mmol}$ ), and trimethylamine $(363 \mu \mathrm{L}, 2.60 \mathrm{mmol})$ in DCM $(10 \mathrm{~mL})$ were stirred at room temperature for $18 \mathrm{~h}$. Purification was performed using silica column chromatography with a $20 \%$ EtOAc/80\% hexanes solvent mixture to provide a white solid. Following purification, a $36 \%$ yield (0.337 g) 
was obtained. ${ }^{1} \mathrm{H}$ NMR $\left(\mathrm{CDCl}_{3}, 600 \mathrm{MHz}\right)$ : 8.03-8.01 (m, 1H), 7.89-7.87 (m, 3H), $7.69(\mathrm{~d}, J=$ $7.12 \mathrm{HZ}, 1 \mathrm{H}), 7.52-7.48(\mathrm{~m}, 3 \mathrm{H}), 7.46(\mathrm{~d}, J=7.49 \mathrm{~Hz}, 2 \mathrm{H}), 7.37-7.31(\mathrm{~m}, 3 \mathrm{H}) .{ }^{13} \mathrm{C}\left\{{ }^{1} \mathrm{H}\right\} \mathrm{NMR}$ $\left(\mathrm{CDCl}_{3}, 151 \mathrm{MHz}\right): 158.41,138.58,134.07,130.59,129.54,129.05,128.83,128.62,127.66$, 126.76, 126.05, 125.94, 125.36, 123.75, 77.50. ${ }^{19} \mathrm{~F} \mathrm{NMR}\left(\mathrm{CDCl}_{3}, 376 \mathrm{MHz}\right):-137.38$ (m, 2F), -

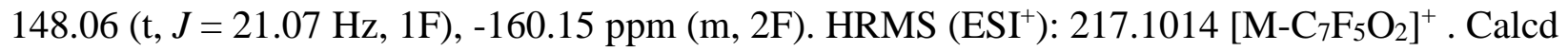
for $\left[\mathrm{C}_{17} \mathrm{H}_{13}\right]: 217.1012$.<smiles>O=C(OC(c1ccccc1)c1ccc2ccccc2c1)c1c(F)c(F)c(F)c(F)c1F</smiles>

(2-naphthyl)(phenyl)methyl 2,3,4,5,6-pentafluorobenzoate.

Phenylmagnesium bromide (3M in diethyl ether, $2.60 \mathrm{~mL}, 7.68$ mmol) was added to a solution of 2-naphthyl aldehyde (1.000 g, $6.400 \mathrm{mmol})$ in THF $(50 \mathrm{~mL})$ at $0{ }^{\circ} \mathrm{C}$ in a $100 \mathrm{~mL}$ Schlenk flask under a dinitrogen atmosphere. The reaction was warmed to room temperature and stirred for $18 \mathrm{~h}$. At this time, the reaction was quenched with aqueous ammonium chloride $(15 \mathrm{~mL})$. The aqueous layer was extracted three times with EtOAc $(10 \mathrm{~mL})$ and the combined organic layers were washed with concentrated aqueous sodium chloride $(15 \mathrm{~mL})$. The organic layer was dried over sodium sulfate, filtered, concentrated to provide (2-naphthyl)(phenyl)methanol, which was used as is for the synthesis of (2-naphthyl)(phenyl)methyl 2,3,4,5,6-pentafluorobenzoate. Following general procedure (B), a mixture of 2,3,4,5,6-pentafluorobenzoyl chloride $(313 \mu \mathrm{L}$, $2.17 \mathrm{mmol})$, (2-naphthyl)(phenyl)methanol (0.508 g, $2.17 \mathrm{mmol})$, DMAP (0.013 g, $0.11 \mathrm{mmol})$, and trimethylamine $(363 \mu \mathrm{L}, 2.60 \mathrm{mmol})$ in DCM $(10 \mathrm{~mL})$ were stirred at room temperature for 18 h. Purification was performed using silica column chromatography with a $20 \%$ EtOAc/80\% hexanes solvent mixture to provide a white solid. Following purification, a 23\% yield (0.210 g) was obtained. ${ }^{1} \mathrm{H} \mathrm{NMR}\left(\mathrm{CDCl}_{3}, 400 \mathrm{MHz}\right)$ : 7.92 (br. s, $\left.1 \mathrm{H}\right), 7.86-7.81(\mathrm{~m}, 3 \mathrm{H}), 7.51-7.46(\mathrm{~m}, 5 \mathrm{H})$, 7.40-7.33 (m, 3H) $7.29 \mathrm{ppm}(\mathrm{s}, 1 \mathrm{H}) .{ }^{13} \mathrm{C}\left\{{ }^{1} \mathrm{H}\right\} \mathrm{NMR}\left(\mathrm{CDCl}_{3}, 101 \mathrm{MHz}\right): 139.00,136.39,133.19$, 128.86, 128.80, 128.57, 128.36, 127.85, 127.36, 126.68, 126.63, 126.52, 124.83, 80.00 ppm. ${ }^{19} \mathrm{~F}$ $\mathrm{NMR}\left(\mathrm{CDCl}_{3}, 376 \mathrm{MHz}\right):-137.39$ (m 2F), -147.98 (t, $\left.J=21.13 \mathrm{~Hz}, 1 \mathrm{~F}\right),-160.15 \mathrm{ppm}(\mathrm{m}, 2 \mathrm{~F})$. HRMS (ESI $\left.{ }^{+}\right): 217.1012\left[\mathrm{M}-\mathrm{C}_{7} \mathrm{~F}_{5} \mathrm{O}_{2}\right]^{+}$. Calcd for $\left[\mathrm{C}_{17} \mathrm{H}_{13}\right]: 217.1012$.<smiles>O=C(OC(c1ccccc1)c1ccccn1)c1c(F)c(F)c(F)c(F)c1F</smiles>

(phenyl)(2-pyridyl) methyl 2,3,4,5,6-pentafluorobenzoate. Following general procedure (A), a mixture of 2,3,4,5,6-pentafluorobenzoic acid (0.250 g, $1.18 \mathrm{mmol})$, (2-pyridyl)(phenyl)methanol (0.218 g, 1.18 $\mathrm{mmol}), \mathrm{EDC} \cdot \mathrm{HCl}(0.248 \mathrm{~g}, 1.30 \mathrm{mmol})$, and DMAP $(0.036 \mathrm{~g}, 0.30$ $\mathrm{mmol})$ in DCM $(5 \mathrm{~mL})$ were stirred at room temperature for $18 \mathrm{~h}$. Purification was performed using silica column chromatography with a $20 \%$ EtOAc/ $80 \%$ hexanes solvent mixture to provide a white solid. Following purification, a $61 \%$ yield $(0.271 \mathrm{~g})$ was obtained. ${ }^{1} \mathrm{H} \mathrm{NMR}\left(\mathrm{CDCl}_{3}, 400 \mathrm{MHz}\right): 8.59$ (br. d, $J=4.04 \mathrm{~Hz}, 1 \mathrm{H}), 7.72(\mathrm{t}, J=7.78 \mathrm{~Hz}, 1 \mathrm{H}), 7.50(\mathrm{t}, J=8.63 \mathrm{~Hz}, 3 \mathrm{H}), 7.39-7.30(\mathrm{~m}, 3 \mathrm{H})$, $7.22(\mathrm{~m}, 1 \mathrm{H}), 7.12 \mathrm{ppm}(\mathrm{s}, 1 \mathrm{H}) .{ }^{13} \mathrm{C}\left\{{ }^{1} \mathrm{H}\right\} \mathrm{NMR}\left(\mathrm{CDCl}_{3}, 151 \mathrm{MHz}\right): 158.23,149.75,138.03$, 137.16, 128.90, 128.79, 127.58, 123.17, 120.93, 80.58 ppm. $\left.{ }^{19} \mathrm{~F} \mathrm{NMR}_{(\mathrm{CDCl}}, 376 \mathrm{MHz}\right):-137.24$ $(\mathrm{m}, 2 \mathrm{~F}),-147.88(\mathrm{t}, J=20.70 \mathrm{~Hz}, 1 \mathrm{~F}),-160.20 \mathrm{ppm}(\mathrm{m}, 2 \mathrm{~F})$. HRMS $\left(\mathrm{ESI}^{+}\right): 380.0721[\mathrm{M}+\mathrm{H}]^{+}$. Calcd for $\left[\mathrm{C}_{19} \mathrm{H}_{10} \mathrm{~F}_{5} \mathrm{NO}_{2}\right]: 379.0632$. 
<smiles>O=C(OC(c1cccc2ccccc12)c1cccc2ccccc12)c1c(F)c(F)c(F)c(F)c1F</smiles>

Bis(1-naphthyl)methyl 2,3,4,5,6-pentafluorobenzoate. Following general procedure (A), a mixture of 2,3,4,5,6-pentafluorobenzoic acid (0.500 g, $2.36 \mathrm{mmol})$, bis(1-naphthyl)methanol $(0.671 \mathrm{~g}, 2.36 \mathrm{mmol})$, $\mathrm{EDC} \cdot \mathrm{HCl}(0.497 \mathrm{~g}, 2.60 \mathrm{mmol})$, and DMAP $(0.065 \mathrm{~g}, 0.53 \mathrm{mmol})$ in DCM $(10 \mathrm{~mL})$ were stirred at room temperature for $18 \mathrm{~h}$. Purification was performed using silica column chromatography with $100 \%$ hexanes to provide a white solid. Following purification, a 19\% yield $(0.214 \mathrm{~g})$ was obtained. ${ }^{1} \mathrm{H} \mathrm{NMR}\left(\mathrm{CDCl}_{3}, 400 \mathrm{MHz}\right): 8.69(\mathrm{~s}, 1 \mathrm{H})$, 8.03-8.01 (m, 2H), 7.94-7.88 (m, 4H), 7.55-7.49 (m, 6H), 7.44 ppm (t, $J=7.95 \mathrm{~Hz}, 2 \mathrm{H}) .{ }^{13} \mathrm{C}\left\{{ }^{1} \mathrm{H}\right\}$ NMR ( $\left.\mathrm{CDCl}_{3}, 126 \mathrm{MHz}\right)$ : 134.02, 133.68, 131.03, 129.72, 129.17, 127.11, 126.28, 126.21, 125.44, 123.23, 73.97 ppm. ${ }^{19} \mathrm{~F} \mathrm{NMR}\left(\mathrm{CDCl}_{3}, 376 \mathrm{MHz}\right):-137.62(\mathrm{~m}, 2 \mathrm{~F}),-148.43(\mathrm{t}, J=20.88,4.43 \mathrm{~Hz}$, $1 \mathrm{~F}),-160.09 \mathrm{ppm}(\mathrm{m}, 2 \mathrm{~F})$. HRMS (ESI $\left.{ }^{+}\right): 267.117\left[\mathrm{M}-\mathrm{C}_{7} \mathrm{~F}_{5} \mathrm{O}_{2}\right]^{+}$. Calcd for $\left[\mathrm{C}_{21} \mathrm{H}_{15}\right]: 267.11683$.<smiles>O=C(OC(c1ccccc1)c1ccc(Cl)cc1)c1c(F)c(F)c(F)c(F)c1F</smiles>

(4-chlorophenyl)(phenyl)methyl 2,3,4,5,6-pentafluorobenzoate. Following general procedure (A), a mixture of 2,3,4,5,6pentafluorobenzoic acid $(0.500 \mathrm{~g}, 2.36 \mathrm{mmol}), \quad$ (4chlorophenyl)(phenyl)methanol $(0.516 \mathrm{mg}, 2.36 \mathrm{mmol}), \mathrm{EDC} \cdot \mathrm{HCl}$ $(0.497 \mathrm{~g}, 2.60 \mathrm{mmol})$, and DMAP $(0.065 \mathrm{~g}, 0.53 \mathrm{mmol})$ in DCM $(10 \mathrm{~mL})$ were stirred at room temperature for $18 \mathrm{~h}$. Purification was performed using silica column chromatography with a 5\% EtOAc/95\% hexanes solvent mixture to provide a white solid. Following purification, a 52\% yield $(0.509 \mathrm{~g})$ was obtained. ${ }^{1} \mathrm{H} \mathrm{NMR}\left(\mathrm{CDCl}_{3}, 500 \mathrm{MHz}\right): 7.39-7.35(\mathrm{~m}, 9 \mathrm{H}), 7.08 \mathrm{ppm}(\mathrm{s}, 1 \mathrm{H})$. ${ }^{13} \mathrm{C}\left\{{ }^{1} \mathrm{H}\right\} \mathrm{NMR}\left(\mathrm{CDCl}_{3}, 151 \mathrm{MHz}\right): 158.20,146.71,145.04,144.66,143.06,138.75,138.64$, $137.68,137.26,134.48,129.06,128.94,128.73,128.70,127.19,79.11 \mathrm{ppm} .{ }^{19} \mathrm{~F} \mathrm{NMR}\left(\mathrm{CDCl}_{3}\right.$, $376 \mathrm{MHz}):-137.41(\mathrm{~m}, 2 \mathrm{H}),-147.68(\mathrm{t}, J=15.67,5.35 \mathrm{~Hz}, 1 \mathrm{H}), 160.02 \mathrm{ppm}(\mathrm{m}, 2 \mathrm{H})$. HRMS $\left(\mathrm{ESI}^{+}\right): 201.0464\left[\mathrm{M}_{-} \mathrm{C}_{7} \mathrm{~F}_{5} \mathrm{O}_{2}\right]^{+}$. Calcd for $\left[\mathrm{C}_{13} \mathrm{H}_{10} \mathrm{Cl}\right]: 201.0466$.<smiles>Cc1ccc(C(OC(=O)c2c(F)c(F)c(F)c(F)c2F)c2ccccc2)cc1</smiles>

4-methylphenyl)(phenyl)methyl pentafluorobenzoate. Following general procedure (A), a mixture of 2,3,4,5,6-pentafluorobenzoic acid (0.343 g, $1.61 \mathrm{mmol})$, rac-(4-methylphenyl)(phenyl)methanol $(0.320 \mathrm{~g}$, $1.61 \mathrm{mmol}), \mathrm{EDC} \cdot \mathrm{HCl}(0.340 \mathrm{~g}, 1.78 \mathrm{mmol})$, and DMAP $(0.049 \mathrm{~g}, 0.40$ $\mathrm{mmol})$ in DCM $(10 \mathrm{~mL})$ were stirred at room temperature for $18 \mathrm{~h}$. Purification was performed using silica column chromatography with a $1 \% \mathrm{EtOAc} / 99 \%$ hexanes solvent mixture to provide a white solid at $8 \%$ yield $(0.053 \mathrm{~g})$. HPLC analysis was performed on Chiralpak AD-H chiral column under ambient temperature $(0.7 \mathrm{~mL} / \mathrm{min}, 2.5 \% \mathrm{EtOH} / \mathrm{Hexanes}) .{ }^{1} \mathrm{H}$ and ${ }^{13} \mathrm{C} \mathrm{NMR}$ data were consistent with that published in the literature. ${ }^{10}$ 


\section{II(C). Synthesis of chiral (diaryl)methyl pentafluorobenzoate}<smiles>Cc1ccc(C(OC(=O)c2c(F)c(F)c(F)c(F)c2F)c2ccccc2)cc1</smiles>

(S)-(4-methylphenyl)(phenyl)methyl pentafluorobenzoate.

To a $100 \mathrm{~mL}$ Schlenk flask containing phenylboronic acid $(0.293 \mathrm{~g}$, $2.40 \mathrm{mmol})$ and dry, degassed toluene $(4 \mathrm{~mL}), \mathrm{Et}_{2} \mathrm{Zn}(7.20 \mathrm{~mL}, 1 \mathrm{M}$ in hexanes, $7.20 \mathrm{mmol}$ ) was added dropwise under a flow of dinitrogen and stirred at $60{ }^{\circ} \mathrm{C}$ for $16 \mathrm{~h}$. The reaction was cooled to room temperature, and a solution of $(S)$-(1-methyl-2-pyrrolidinyl) diphenylmethanol $(0.027 \mathrm{mg}, 0.10 \mathrm{mmol})$ in toluene $(2 \mathrm{~mL})$ was added and stirred at room temperature for $15 \mathrm{~min}$. 4-methylbenzaldehyde (118 $\mu \mathrm{L}, 1.019 \mathrm{~g} / \mathrm{mL}, 0.120 \mathrm{~g}, 1.00 \mathrm{mmol}$ ) was then added under a flow of dinitrogen and the reaction mixture stirred at room temperature for $16 \mathrm{~h}$. After the reaction was complete, it was quenched with water $(10 \mathrm{~mL})$, and the aqueous layer was extracted three times with DCM $(10 \mathrm{~mL})$ and the combined organic layers were dried over sodium sulfate or magnesium sulfate, filtered, and concentrated to provide (S)-(4-methylphenyl)(phenyl)methano, which was used as is for the synthesis of $(S)$-(4-methylphenyl)(phenyl)methyl pentafluorobenzoate.

Following general procedure (A), a mixture of 2,3,4,5,6-pentafluorobenzoic acid $(0.343 \mathrm{~g}, 1.61$ $\mathrm{mmol}),(S)$-(4-methylphenyl)(phenyl)methanol $(0.320 \mathrm{~g}, 1.61 \mathrm{mmol})$, EDC $\cdot \mathrm{HCl}(0.340 \mathrm{~g}, 1.78$ $\mathrm{mmol})$, and DMAP $(0.049 \mathrm{~g}, 0.40 \mathrm{mmol})$ in DCM $(10 \mathrm{~mL})$ were stirred at room temperature for $18 \mathrm{~h}$. Purification was performed using silica column chromatography with a $1 \%$ EtOAc/99\% PE solvent mixture to provide a white solid at $43 \%$ yield $(0.272 \mathrm{~g}), 84 \%$ ee. Enantiomeric ratio was determined by HPLC analysis in comparison with a racemic sample. Chiralpak AD-H column, ambient temperature, $2.5 \% \mathrm{EtOH} / \mathrm{Hexanes}, 0.7 \mathrm{~mL} / \mathrm{min}$, major isomer: $7.730 \mathrm{~min}$, minor isomer: $7.281 \mathrm{~min} .{ }^{1} \mathrm{H} \mathrm{NMR}\left(\mathrm{CDCl}_{3}, 600 \mathrm{MHz}\right): 7.42(\mathrm{~d}, J=7.63 \mathrm{~Hz}, 2 \mathrm{H}), 7.36(\mathrm{t}, J=8.47 \mathrm{~Hz}, 2 \mathrm{H}), 7.32-$ $7.29(\mathrm{~m}, 3 \mathrm{H}), 7.18(\mathrm{~d}, J=7.62 \mathrm{~Hz}, 2 \mathrm{H}), 7.09(\mathrm{~s}, 1 \mathrm{H}), 2.34 \mathrm{ppm}(2,3 \mathrm{H}) .{ }^{13} \mathrm{C}\left\{{ }^{1} \mathrm{H}\right\} \mathrm{NMR}\left(\mathrm{CDCl}_{3}\right.$, $151 \mathrm{MHz}): 158.29,139.29,138.41,136.22,129.50,128.79,128.39,127.34,127.16,79.87,21.31$ ppm. ${ }^{19} \mathrm{~F}$ NMR $\left(\mathrm{CDCl}_{3}, 376 \mathrm{MHz}\right)$ : -137.52 (m, 2F), -148.23 (t, $\left.J=21.13 \mathrm{~Hz}, 1 \mathrm{~F}\right),-160.31 \mathrm{ppm}$ (m, 2F). ${ }^{1} \mathrm{H}$ and ${ }^{13} \mathrm{C}$ NMR data were consistent with that published in the literature for the racemic compound. ${ }^{10}[\alpha]^{20}{ }_{\mathrm{D}}-7.91\left(\mathrm{c} 0.867, \mathrm{CHCl}_{3}\right)$. HRMS $\left(\mathrm{ESI}^{+}\right)$: $392.2865[\mathrm{M}+\mathrm{H}]^{+}$. Calcd for $\left[\mathrm{C}_{21} \mathrm{H}_{13} \mathrm{~F}_{5} \mathrm{O}_{2}\right] 392.0836$.<smiles>O=C(O[C@H](c1ccccc1)c1ccc2ccccc2c1)c1c(F)c(F)c(F)c(F)c1F</smiles>

\section{(S)-(2-naphthyl)(phenyl)methyl pentafluorobenzoate.}

To a $100 \mathrm{~mL}$ Schlenk flask containing phenylboronic acid $(0.293 \mathrm{~g}$, $2.40 \mathrm{mmol})$ and dry, degassed toluene $(4 \mathrm{~mL}), \mathrm{Et}_{2} \mathrm{Zn}(7.20 \mathrm{~mL}, 1 \mathrm{M}$ in hexanes, $7.20 \mathrm{mmol}$ ) was added dropwise under a flow of dinitrogen and stirred at $60{ }^{\circ} \mathrm{C}$ for $16 \mathrm{~h}$. The reaction was cooled to room temperature, and a solution of $(S)$-(1-methyl-2-pyrrolidinyl) diphenylmethanol $(0.027 \mathrm{mg}, 0.10 \mathrm{mmol})$ in toluene $(2 \mathrm{~mL})$ was added and stirred at room temperature for $15 \mathrm{~min}$. 2-naphthylaldehyde (118 $\mu \mathrm{L}, 1.019 \mathrm{~g} / \mathrm{mL}, 0.120 \mathrm{~g}, 1.00 \mathrm{mmol}$ ) was then added under a flow of dinitrogen and the reaction mixture stirred at room temperature for $16 \mathrm{~h}$. After the reaction was complete, it was quenched with water $(10 \mathrm{~mL})$, and the aqueous layer was extracted three times with DCM $(10 \mathrm{~mL})$ and the combined organic layers were dried over sodium sulfate or magnesium sulfate, filtered, and concentrated. Purification was performed using silica column chromatography with a $20 \%$ EtOAc/80\% hexanes solvent mixture to provide (S)-(2naphthyl)(phenyl)methanol as a white solid in $88 \%$ yield $(0.206 \mathrm{mg}) .{ }^{1} \mathrm{H}$ NMR data was consistent 
with that published in the literature. ${ }^{3}$ Following general procedure $(\mathbf{B})$, a mixture of $2,3,4,5,6$ pentafluorobenzoyl chloride $(313 \mu \mathrm{L}, 2.17 \mathrm{mmol})$, (S)-(2-naphthyl)(phenyl)methanol $(0.192 \mathrm{~g}$, $0.821 \mathrm{mmol})$, DMAP $(0.005 \mathrm{~g}, 0.04 \mathrm{mmol})$, and trimethylamine $(137 \mu \mathrm{L}, 0.985 \mathrm{mmol})$ in DCM $(10 \mathrm{~mL})$ were stirred at room temperature for $18 \mathrm{~h}$. Purification was performed using silica column chromatography with a $20 \%$ EtOAc/ $80 \%$ hexanes solvent mixture to provide a white solid at $36 \%$ yield $(0.337 \mathrm{~g}), 86 \%$ ee. Enantiomeric ratio was determined by HPLC analysis in comparison with a racemic sample (following the same procedure) using Chiralpak OD-H column, ambient temperature, $5 \%{ }^{\mathrm{i}} \mathrm{PrOH} / \mathrm{Hexanes}, 1.5 \mathrm{~mL} / \mathrm{min}$, major isomer: $4.216 \mathrm{~min}$, minor isomer: $3.862 \mathrm{~min}$. ${ }^{1} \mathrm{H} \mathrm{NMR}\left(\mathrm{CDCl}_{3}, 600 \mathrm{MHz}\right): 7.92(\mathrm{~s}, 1 \mathrm{H}), 7.86-7.82(\mathrm{~m}, 3 \mathrm{H}), 7.51-7.46(\mathrm{~m}, 5 \mathrm{H}), 7.38(\mathrm{t}, J=7.33$ $\mathrm{Hz}, 2 \mathrm{H}), 7.33(\mathrm{t}, J=7.17 \mathrm{~Hz}, 1 \mathrm{H}), 7.29(\mathrm{~s}, 1 \mathrm{H}) .{ }^{13} \mathrm{C}\left\{{ }^{1} \mathrm{H}\right\} \mathrm{NMR}\left(\mathrm{CDCl}_{3}, 151 \mathrm{MHz}\right): 158.32,139.01$, 136.40, 133.24, 133.20, 128.86, 128.80, 128.57, 128.37, 127.85, 127.37, 126.68, 126.63, 126.53, 124.83, 80.00 ppm. ${ }^{19} \mathrm{~F}$ NMR $\left(\mathrm{CDCl}_{3}, 376 \mathrm{MHz}\right)$ : -137.46 (m, 2F), -147.97 (m, 1F), -160.16 ppm $(\mathrm{m}, 2 \mathrm{~F})$. This compound did not ionize well enough to acquire HRMS data. $[\alpha]^{20} \mathrm{D}+11.76$ (c 0.73 , $\mathrm{CHCl}_{3}$ ). 


\section{II(D). Synthesis of phenyl benzoate derivatives}<smiles>O=C(Oc1ccccc1)c1c(F)c(F)c(F)c(F)c1F</smiles>

Phenyl 2,3,4,5,6-pentafluorobenzoate. Following general procedure (A), a mixture of 2,3,4,5,6-pentafluorobenzoic acid $(0.500 \mathrm{~g}, 2.36$ $\mathrm{mmol})$, phenol $(0.222 \mathrm{~g}, 2.36 \mathrm{mmol}), \mathrm{EDC} \cdot \mathrm{HCl}(0.497 \mathrm{~g}, 2.59 \mathrm{mmol})$, and DMAP $(0.072 \mathrm{~g}, 0.59 \mathrm{mmol})$ in DCM $(10 \mathrm{~mL})$ were stirred at room temperature for $18 \mathrm{~h}$. Purification was performed using silica column chromatography using a gradient of $100 \%$ hexanes to $20 \%$ EtOAc/80\% hexanes solvent mixture to provide a white solid. Following purification, a $42 \%$ yield $(0.285 \mathrm{~g})$ was obtained. ${ }^{1} \mathrm{H} \mathrm{NMR}\left(\mathrm{CDCl}_{3}, 400 \mathrm{MHz}\right): 7.46(\mathrm{t}, J=8.00 \mathrm{~Hz}, 2 \mathrm{H}), 7.32(\mathrm{t}, J=7.26 \mathrm{~Hz}, 1 \mathrm{H})$, 7.24 (d obstructed by solvent, $2 \mathrm{H}) \mathrm{ppm} .{ }^{13} \mathrm{C}\left\{{ }^{1} \mathrm{H}\right\} \mathrm{NMR}\left(\mathrm{CDCl}_{3}, 101 \mathrm{MHz}\right): 157.65,150.16$, $147.15,144.77,142.50,139.25,136.69,129.88,126.92,121.40 \mathrm{ppm} .{ }^{19} \mathrm{~F} \mathrm{NMR}\left(\mathrm{CDCl}_{3}, 376\right.$ MHz): $-137.29(\mathrm{~m}, 2 \mathrm{~F}),-147.32(\mathrm{t}, J=26.37,10.42,1 \mathrm{~F}),-159.88 \mathrm{ppm}(\mathrm{m}, 2 \mathrm{~F})$. HRMS $\left(\mathrm{ESI}^{+}\right)$: $289.0269[\mathrm{M}+\mathrm{H}]^{+}$. Calcd for $\left[\mathrm{C}_{13} \mathrm{H}_{6} \mathrm{~F}_{5} \mathrm{O}_{2}\right] 289.0288$.<smiles>O=C(Oc1ccccc1)c1ccccc1P</smiles>

Phenyl 2-(diphenylphosphino)benzoate. Following general procedure (A), a mixture of 2-(diphenylphosphino)benzoic acid (0.500 g, $1.63 \mathrm{mmol})$, phenol $(0.154 \mathrm{~g}, 1.63 \mathrm{mmol}), \mathrm{EDC} \cdot \mathrm{HCl}(0.344 \mathrm{~g}, 1.80 \mathrm{mmol})$, and DMAP $(0.050 \mathrm{~g}, 0.41 \mathrm{mmol})$ in DCM $(10 \mathrm{~mL})$ were stirred at room temperature for $18 \mathrm{~h}$. Purification was performed using silica column chromatography using 5\% EtOAc/95\% hexanes solvent mixture to provide a white solid. Following purification, a 23\% yield $(0.113 \mathrm{~g})$ was obtained. ${ }^{1} \mathrm{H}$ and ${ }^{13} \mathrm{C}$ NMR data were consistent with that published in the literature. ${ }^{11}$ 


\section{Comparison of phenyl and benzyl benzoate in Pd-catalyzed Suzuki-Miyaura reactions}

(Figure 4).

Ester (0.0500 mmol), (4-fluorophenyl)boronic acid (10.5 mg, $0.0750 \mathrm{mmol})$, and $\mathrm{K}_{2} \mathrm{CO}_{3}(13.8 \mathrm{mg}$, $0.100 \mathrm{mmol})$ were added to a 1 dram vial equipped with a magnetic stir bar. $\left(\eta^{3}-1-^{\mathrm{t}} \mathrm{Bu}-\right.$ indenyl) $\mathrm{Pd}(\mathrm{IPr})(\mathrm{Cl})(0.35 \mathrm{mg}, 0.00050 \mathrm{mmol})$ (added as a stock solution in THF), THF $(0.4 \mathrm{~mL})$ and water $(0.1 \mathrm{~mL})$ were added in a glovebox. The vial was stirred at $40{ }^{\circ} \mathrm{C}$ for $16 \mathrm{~h}$ in a metal heating block on a hot plate fitted with a thermocouple. At this time, the vial was opened to air and the mixture was filtered through a silica plug with EtOAc and the conversion was analyzed using GC-FID. The data is shown in Figure 4. 
IV. Comparison of (diphenyl)methyl- acetate, benzoate, pentafluorobenzoate, chloride, and bromide (Figure 5).

(diphenyl)methyl-X (0.0500 mmol), (4-methoxyphenyl)boronic acid (11.4 $\mathrm{mg}, 0.0750 \mathrm{mmol})$, and $\mathrm{K}_{2} \mathrm{CO}_{3}(13.8 \mathrm{mg}, 0.100 \mathrm{mmol})$ were added to a 1 dram vial equipped with a magnetic stir bar. $\left(\eta^{3}-\right.$ 1- ${ }^{\mathrm{B} u}$-indenyl) $\mathrm{Pd}(\mathrm{IPr})(\mathrm{Cl})(0.0005 \mathrm{mmol})$ (added as a stock solution in toluene), toluene $(0.4 \mathrm{~mL})$ and ethanol $(0.1 \mathrm{~mL})$ were added in a glovebox. The vial was stirred at room temperature for $6 \mathrm{~h}$. At this time, the vial was opened to air and the mixture was filtered through a silica plug with EtOAc and the yield of product, as well as the yields of the side-products were analyzed using GCFID. The data is shown in Figure 5. 


\section{Optimization of Pd-catalyzed Suzuki-Miyaura reaction of (diphenyl)methyl pentafluorobenzoate with 4-methoxyphenylboronic acid (Table 1 and S1).}

The following general procedure was used for reaction optimization of Pd-catalyzed SuzukiMiyaura reactions of (diphenyl)methyl pentafluorobenzoate with 4-methoxyphenylboronic acid:

(Diphenyl)methyl pentafluorobenzoate $(0.0500 \mathrm{mmol})$, (4-methoxyphenyl)boronic acid $(0.0750$ $\mathrm{mmol})$, and base $(0.100 \mathrm{mmol})$ were added to a 1 dram vial equipped with a magnetic stir bar. Precatalyst $(0.0005 \mathrm{mmol})$ (added as a stock solution in the given solvent) and solvent $(0.5 \mathrm{~mL})$ were added in a glovebox. The vial was stirred at the given temperature and time. At this time, the vial was opened to air and the mixture was filtered through a silica plug with EtOAc and the conversion was analyzed using GC-FID. The results are provided in Tables 1 and S1. 
Table S1. Optimization table for Pd-catalyzed Suzuki-Miyaura reaction of diarylmethyl 2,3,4,5,6pentafluorobenzoate with 4-methoxyphenylboronic acid.

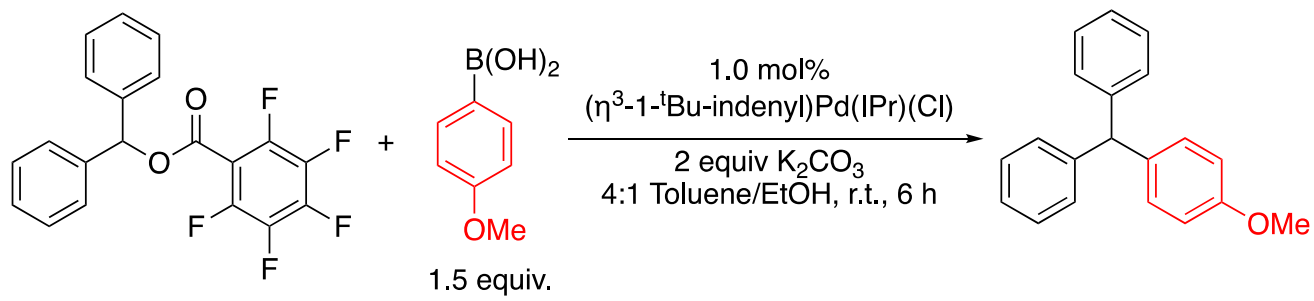

\begin{tabular}{|c|c|c|}
\hline Entry & Deviation from optimized condition & Conversion $^{\mathrm{a}}$ \\
\hline 1 & No change & $85 \%$ \\
\hline 2 & No precatalyst & $0 \%^{\mathrm{b}}$ \\
\hline 3 & $24 \mathrm{~h}$ instead of $6 \mathrm{~h}$ & $>99 \%$ \\
\hline 4 & $8 \mathrm{~h}$ instead of $6 \mathrm{~h}$ & $85 \%$ \\
\hline 5 & $40{ }^{\circ} \mathrm{C}$ instead of r.t. and $2 \mathrm{~h}$ instead of $6 \mathrm{~h}$ & $94 \%$ \\
\hline 6 & $40{ }^{\circ} \mathrm{C}$ instead of r.t. and $4 \mathrm{~h}$ instead of $6 \mathrm{~h}$ & $>99 \%$ \\
\hline 7 & $\mathrm{H}_{5} \mathrm{C}_{6} \mathrm{COOCHPh}_{2}$ instead of $\mathrm{F}_{5} \mathrm{C}_{6} \mathrm{COOCHPh}_{2}$ & $35 \%$ \\
\hline 8 & $\mathrm{H}_{3} \mathrm{CCOOCHPh}_{2}$ instead of $\mathrm{F}_{5} \mathrm{C}_{6} \mathrm{COOCHPh}_{2}$ & $28 \%$ \\
\hline 9 & $\mathrm{H}_{2} \mathrm{O}$ instead of EtOH & $69 \%$ \\
\hline 10 & $\mathrm{MeOH}$ instead of EtOH & $89 \%^{c}$ \\
\hline 11 & ${ }^{\mathrm{i}} \mathrm{PrOH}$ instead of EtOH & $56 \%$ \\
\hline 12 & THF instead of toluene & $43 \%$ \\
\hline 13 & 1,4-Dioxane instead of toluene & $39 \%$ \\
\hline 14 & Toluene/EtOH (1:4) instead of $(4: 1)$ & $72 \%{ }^{\mathrm{d}}$ \\
\hline 15 & $\mathrm{~K}_{3} \mathrm{PO}_{4}$ instead of $\mathrm{K}_{2} \mathrm{CO}_{3}$ & $63 \%$ \\
\hline 16 & $\mathrm{Na}_{2} \mathrm{CO}_{3}$ instead of $\mathrm{K}_{2} \mathrm{CO}_{3}$ & $2 \%$ \\
\hline 17 & $\mathrm{Cs}_{2} \mathrm{CO}_{3}$ instead of $\mathrm{K}_{2} \mathrm{CO}_{3}$ & $27 \%$ \\
\hline 18 & $\left(\eta^{3}\right.$-cinnamyl)Pd(IPr)Cl instead of $\left(\eta^{3}-1-^{t} \mathrm{Bu}\right.$-indenyl)Pd(IPr)Cl & $73 \%$ \\
\hline 19 & PEPPSI-IPr instead of $\left(\eta^{3}-1-{ }^{t} \mathrm{Bu}\right.$-indenyl $) \mathrm{Pd}(\mathrm{IPr}) \mathrm{Cl}$ & $64 \%$ \\
\hline 20 & SIPr instead of IPr & $62 \%$ \\
\hline 21 & IMes instead of IPr & $16 \%$ \\
\hline 22 & $\mathrm{IPr}^{*} \mathrm{OMe}$ instead of IPr & $40 \%$ \\
\hline 23 & РСуз instead of IPr & $2 \%^{\mathrm{f}}$ \\
\hline 24 & XPhos instead of IPr & $3 \%$ \\
\hline 25 & SPhos instead of IPr & $46 \%{ }^{\mathrm{g}}$ \\
\hline
\end{tabular}

${ }^{\mathrm{a}}$ Conversions are an average of two runs determined using GC-FID. ${ }^{\mathrm{b}} 64 \%$ conversion to $\mathrm{F}_{5} \mathrm{C}_{6} \mathrm{COOC}_{2} \mathrm{H}_{5}, 2 \% \mathrm{ArCOOC}_{2} \mathrm{H}_{5}$, and $36 \%$ starting material remaining. ${ }^{\mathrm{c}} 9 \%$ conversion to $\mathrm{F}_{5} \mathrm{C}_{6} \mathrm{COOCH}_{3}$. ${ }^{\mathrm{d}} 21 \%$ conversion to $\mathrm{F}_{5} \mathrm{C}_{6} \mathrm{COOC}_{2} \mathrm{H}_{5}$ and $7 \% \mathrm{ArCOOC}_{2} \mathrm{H}_{5}$. ${ }^{\mathrm{e}} 36 \%$ conversion to $\mathrm{F}_{5} \mathrm{C}_{6} \mathrm{COOC}_{2} \mathrm{H}_{5}$ and $38 \% \mathrm{ArCOOC}_{2} \mathrm{H}_{5} .{ }^{\mathrm{f}} 67 \%$ conversion to $\mathrm{F}_{5} \mathrm{C}_{6} \mathrm{COOC}_{2} \mathrm{H}_{5}$. ${ }^{\mathrm{g}} 32 \%$ conversion to $\mathrm{F}_{5} \mathrm{C}_{6} \mathrm{COOC}_{2} \mathrm{H}_{5}$. 


\section{VI(A). Substrate scope for Pd-catalyzed Suzuki-Miyaura reactions of (diaryl)methyl pentafluorobenzoate and phenyl boronic acid (Figure 6)}

The following general procedure was used for reactions between (diaryl)methyl pentafluorobenzoate and phenyl boronic acids.

(Diaryl)methyl pentafluorobenzoate $(0.200 \mathrm{mmol})$, phenyl boronic acid $(0.300 \mathrm{mmol})$, and $\mathrm{K}_{2} \mathrm{CO}_{3}$ $(0.400 \mathrm{mmol})$ were added to a 1 dram vial equipped with a magnetic stir bar. $\left(\eta^{3}-1-{ }^{\mathrm{t}} \mathrm{Bu}-\right.$ indenyl) $\mathrm{Pd}(\mathrm{IPr})(\mathrm{Cl})(0.0020$ or $0.0080 \mathrm{mmol})$ (added as a stock solution in toluene), toluene (1.6 $\mathrm{mL})$ and ethanol or water $(0.4 \mathrm{~mL})$ were added in a glovebox. The vial was stirred at 40 or $80{ }^{\circ} \mathrm{C}$ for 4 or $16 \mathrm{~h}$ in a metal heating block on a hot plate fitted with a thermocouple. At this time, the vial was opened to air and the crude mixture was filtered through a silica plug and concentrated. Purification was performed using normal-phase column chromatography or preparatory TLC.<smiles>c1ccc(C(c2ccccc2)c2ccccc2)cc1</smiles>

triphenyl methane $(6 a / 8 a)$. Following the general procedure above, a mixture of (diphenyl)methyl 2,3,4,5,6-pentafluorobenzoate (75.7 $\mathrm{mg}, 0.200 \mathrm{mmol}$ ), phenyl boronic acid (36.6 mg, $0.300 \mathrm{mmol}), \mathrm{K}_{2} \mathrm{CO}_{3}(55.3 \mathrm{mg}, 0.400 \mathrm{mmol})$, and $\left(\eta^{3}-1-^{t} \mathrm{Bu}\right.$-indenyl)Pd(IPr) $(\mathrm{Cl})(1.4 \mathrm{mg}, 0.0020 \mathrm{mmol})$ in toluene $(1.6 \mathrm{~mL})$ and ethanol $(0.4 \mathrm{~mL})$ were stirred at $40{ }^{\circ} \mathrm{C}$ for $4 \mathrm{~h}$. Purification was performed using silica column chromatography with a $1 \%$ EtOAc/99\% PE solvent mixture to provide a white solid in a yield of $96 \%(47.0 \mathrm{mg}) .{ }^{1} \mathrm{H}$ and ${ }^{13} \mathrm{C}$ NMR data were consistent with that published in the literature. ${ }^{12}$

Scale up: The general procedure was performed on a $1 \mathrm{mmol}$ scale. A mixture of (diphenyl)methyl 2,3,4,5,6-pentafluorobenzoate $(378.5 \mathrm{mg}, 1 \mathrm{mmol})$, phenyl boronic acid (183.0 $\mathrm{mg}, 1.5 \mathrm{mmol}), \mathrm{K}_{2} \mathrm{CO}_{3}(276.5 \mathrm{mg}, 2 \mathrm{mmol})$, and $\left(\eta^{3}-1-^{\mathrm{t}} \mathrm{Bu}\right.$-indenyl)Pd(IPr)(Cl) (7.0 mg, $\left.0.1 \mathrm{mmol}\right)$ in toluene $(8 \mathrm{~mL})$ and ethanol $(2 \mathrm{~mL})$ were added to a 6 dram vial and stirred at $40{ }^{\circ} \mathrm{C}$ for $4 \mathrm{~h}$. Purification was performed using silica column chromatography with a $1 \%$ EtOAc/99\% PE solvent mixture to provide a white solid in a yield of $95 \%(232.6 \mathrm{mg})$.

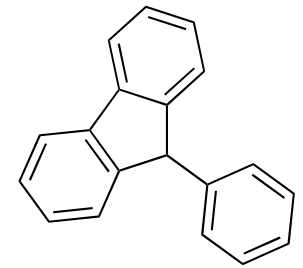

9-phenylfluorene $(\boldsymbol{6} \boldsymbol{b})$. Following the general procedure above, a mixture of 9-(2,3,4,5,6-pentafluorobenzoate)-9H-fluorene (75.3 $\mathrm{mg}, 0.200 \mathrm{mmol})$, phenyl boronic acid (36.6 mg, $0.300 \mathrm{mmol}), \mathrm{K}_{2} \mathrm{CO}_{3}(55.3 \mathrm{mg}, 0.400 \mathrm{mmol})$, and $\left(\eta^{3}-\right.$ 1 - $^{\mathrm{Bu}} \mathrm{B}$-indenyl $) \mathrm{Pd}(\mathrm{IPr})(\mathrm{Cl})(1.4 \mathrm{mg}, 0.0020 \mathrm{mmol})$ in toluene $(1.6 \mathrm{~mL})$ and ethanol $(0.4 \mathrm{~mL})$ were stirred at $40^{\circ} \mathrm{C}$ for $4 \mathrm{~h}$. Purification was performed using silica column chromatography with $100 \%$ hexanes to provide a white solid in a yield of $94 \%(45.5 \mathrm{mg}) .{ }^{1} \mathrm{H}$ and ${ }^{13} \mathrm{C}$ NMR data were consistent with that published in the literature. ${ }^{13}$<smiles>COc1ccc(C(c2ccccc2)c2ccccc2)cc1</smiles>

(4-methoxyphenyl)diphenylmethane (6c). Following the general procedure above, a mixture of (4-methoxyphenyl)(phenyl)methyl 2,3,4,5,6-pentafluorobenzoate $(81.7 \mathrm{mg}, 0.200 \mathrm{mmol})$, phenyl boronic acid (36.6 mg, $0.300 \mathrm{mmol}), \mathrm{K}_{2} \mathrm{CO}_{3}(55.3 \mathrm{mg}, 0.400 \mathrm{mmol})$, and $\left(\eta^{3}-1-\right.$ ${ }^{t} \mathrm{Bu}$-indenyl)Pd(IPr) $(\mathrm{Cl})(1.4 \mathrm{mg}, 0.0020 \mathrm{mmol})$ in toluene $(1.6 \mathrm{~mL})$ and ethanol $(0.4 \mathrm{~mL})$ were stirred at $40{ }^{\circ} \mathrm{C}$ for $4 \mathrm{~h}$. Purification was performed using silica column chromatography with $100 \%$ hexanes to $20 \%$ EtOAc/80\% hexanes solvent 
mixture to provide a yellow oil in a yield of $77 \%(42.3 \mathrm{mg}) .{ }^{1} \mathrm{H}$ and ${ }^{13} \mathrm{C}$ NMR data were consistent with that published in the literature. ${ }^{14}$

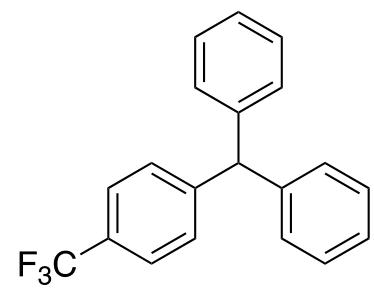

(4-trifluoromethylphenyl)diphenylmethane $(\boldsymbol{6} \boldsymbol{d})$. Following the general procedure above, a mixture of (4-trifluoromethylphenyl)(phenyl)methyl 2,3,4,5,6-pentafluorobenzoate ( $89.3 \mathrm{mg}, 0.200 \mathrm{mmol})$, phenyl boronic acid (36.6 mg, $0.300 \mathrm{mmol}), \mathrm{K}_{2} \mathrm{CO}_{3}(55.3 \mathrm{mg}, 0.400 \mathrm{mmol})$, and $\left(\eta^{3}-1-\right.$ ${ }^{\mathrm{t}} \mathrm{Bu}$-indenyl $) \mathrm{Pd}(\mathrm{IPr})(\mathrm{Cl})(1.4 \mathrm{mg}, 0.0020 \mathrm{mmol})$ in toluene $(1.6 \mathrm{~mL})$ and ethanol $(0.4 \mathrm{~mL})$ were stirred at $40{ }^{\circ} \mathrm{C}$ for $4 \mathrm{~h}$. Purification was performed using silica column chromatography with $100 \%$ hexanes to $2 \%$ EtOAc/98\% hexanes solvent mixture to provide a colorless oil in a yield of $93 \%(58.0 \mathrm{mg}) .{ }^{1} \mathrm{H}$ and ${ }^{13} \mathrm{C}$ NMR data were consistent with that published in the literature. ${ }^{14}$<smiles>N#Cc1ccc(C(c2ccccc2)c2ccc(C#N)cc2)cc1</smiles>
bis(4-cyanophenyl)phenylmethyl (6e). Following the general procedure above, a mixture of bis-(4-cyanophenyl)methyl 2,3,4,5,6pentafluorobenzoate $(85.7 \mathrm{mg}, 0.200 \mathrm{mmol})$, phenyl boronic acid (36.6 $\mathrm{mg}, 0.300 \mathrm{mmol}), \mathrm{K}_{2} \mathrm{CO}_{3}(55.3 \mathrm{mg}, 0.400 \mathrm{mmol})$, and $\left(\eta^{3}-1-{ }^{\mathrm{t}} \mathrm{Bu}-\right.$ indenyl $) \mathrm{Pd}(\mathrm{IPr})(\mathrm{Cl})(1.4 \mathrm{mg}, 0.0020 \mathrm{mmol})$ in toluene $(1.6 \mathrm{~mL})$ and ethanol $(0.4 \mathrm{~mL})$ were stirred at $40{ }^{\circ} \mathrm{C}$ for $4 \mathrm{~h}$. Purification was performed using silica column chromatography with 5\% EtOAc/95\% hexanes to $20 \%$ EtOAc/80\% hexanes solvent mixtures to provide a white solid in a yield of $86 \%(50.5 \mathrm{mg}) .{ }^{1} \mathrm{H}$ NMR $\left(\mathrm{CDCl}_{3}, 400 \mathrm{MHz}\right): 7.62(\mathrm{~d}, J=8.22 \mathrm{~Hz}, 4 \mathrm{H}), 7.36-7.31(\mathrm{~m}, 3 \mathrm{H}), 7.21$ $(\mathrm{d}, J=8.06 \mathrm{~Hz}, 4 \mathrm{H}), 7.05(\mathrm{~d}, J=6.82 \mathrm{~Hz}, 2 \mathrm{H}), 5.63 \mathrm{ppm}(\mathrm{s}, 1 \mathrm{H}) .{ }^{13} \mathrm{C}\left\{{ }^{1} \mathrm{H}\right\} \mathrm{NMR}\left(\mathrm{CDCl}_{3}, 101\right.$ MHz): 148.00, 141.09, 132.58, 130.23, 129.34, 129.11, 127.60, 118.71, 111.11, 56.86 ppm. HRMS $\left(\mathrm{ESI}^{+}\right): 295.1222[\mathrm{M}+\mathrm{H}]^{+}$. Calcd for $\left[\mathrm{C}_{21} \mathrm{H}_{15} \mathrm{~N}_{2}\right] 295.1235$.<smiles>Cc1ccccc1C(c1ccccc1)c1ccccc1</smiles>

(2-methylphenyl)diphenylmethane $(\boldsymbol{6} f)$. Following the general procedure above, a mixture of (2-methylphenyl)(phenyl)methyl 2,3,4,5,6pentafluorobenzoate $(78.5 \mathrm{mg}, 0.200 \mathrm{mmol})$, phenyl boronic acid $(36.6 \mathrm{mg}$, $0.300 \mathrm{mmol}), \quad \mathrm{K}_{2} \mathrm{CO}_{3} \quad(55.3 \mathrm{mg}, \quad 0.400 \mathrm{mmol})$, and $\left(\eta^{3}-1-^{\mathrm{t}} \mathrm{Bu}-\right.$ indenyl) $\mathrm{Pd}(\mathrm{IPr})(\mathrm{Cl})(5.6 \mathrm{mg}, 0.0080 \mathrm{mmol})$ in toluene $(1.6 \mathrm{~mL})$ and water $(0.4$ $\mathrm{mL})$ were stirred at $80{ }^{\circ} \mathrm{C}$ for $16 \mathrm{~h}$. Purification was performed using silica column chromatography with $100 \%$ hexanes to provide a white solid in a yield of $87 \%$ (44.9 $\mathrm{mg}$ ). ${ }^{1} \mathrm{H}$ and ${ }^{13} \mathrm{C}$ NMR data were consistent with that published in the literature. ${ }^{15}$<smiles>c1ccc(C(c2ccccc2)c2cccc3ccccc23)cc1</smiles>

(1-naphthyll)diphenylmethane $(\mathbf{6 g})$. Following the general procedure above, a mixture of (1-naphthyl)(phenyl)methyl 2,3,4,5,6pentafluorobenzoate $(85.7 \mathrm{mg}, 0.200 \mathrm{mmol})$, phenyl boronic acid $(36.6 \mathrm{mg}$, $0.300 \mathrm{mmol}), \quad \mathrm{K}_{2} \mathrm{CO}_{3} \quad(55.3 \mathrm{mg}, \quad 0.400 \mathrm{mmol})$, and $\left(\eta^{3}-1-^{\mathrm{t}} \mathrm{Bu}-\right.$ indenyl) $\mathrm{Pd}(\mathrm{IPr})(\mathrm{Cl})(5.6 \mathrm{mg}, 0.0080 \mathrm{mmol})$ in toluene $(1.6 \mathrm{~mL})$ and water $(0.4 \mathrm{~mL})$ were stirred at $80{ }^{\circ} \mathrm{C}$ for $16 \mathrm{~h}$. Purification was performed by recrystallization from EtOAc layered with hexanes in a $4{ }^{\circ} \mathrm{C}$ freezer. A final wash with hexanes and drying in vacuo provided an off-white solid in a yield of $77 \%(45.5 \mathrm{mg}) .{ }^{1} \mathrm{H}$ and ${ }^{13} \mathrm{C}$ NMR data were consistent with that published in the literature. ${ }^{16}$ 
<smiles>c1ccc(C(c2cccc3ccccc23)c2cccc3ccccc23)cc1</smiles>

(di-naphth-1-yl)phenylmethane $(\boldsymbol{6} \boldsymbol{h})$. Following the general procedure above, a mixture of (di-naphth-1-yl)methyl 2,3,4,5,6-pentafluorobenzoate (95.7 mg, $0.200 \mathrm{mmol}$ ), phenyl boronic acid (36.6 mg, $0.300 \mathrm{mmol}), \mathrm{K}_{2} \mathrm{CO}_{3}$ (55.3 mg, $0.400 \mathrm{mmol})$, and $\left(\eta^{3}-1-^{\mathrm{t}} \mathrm{Bu}\right.$-indenyl $) \mathrm{Pd}(\mathrm{IPr})(\mathrm{Cl})(5.6 \mathrm{mg}, 0.0080$ $\mathrm{mmol})$ in toluene $(1.6 \mathrm{~mL})$ and water $(0.4 \mathrm{~mL})$ were stirred at $80{ }^{\circ} \mathrm{C}$ for 16 h. Purification was performed by recrystallization from DCM layered with hexanes in a $4{ }^{\circ} \mathrm{C}$ freezer. A final wash with hexanes and drying in vacuo provided an off-white solid in a yield of $87 \%(59.6 \mathrm{mg}) .{ }^{1} \mathrm{H} \mathrm{NMR}\left(\mathrm{CDCl}_{3}, 500 \mathrm{MHz}\right): 7.97(\mathrm{~d}, J=8.49 \mathrm{~Hz}, 2 \mathrm{H}), 7.89(\mathrm{~d}$, $J=8.19 \mathrm{~Hz}, 2 \mathrm{H}), 7.77(\mathrm{~d}, J=8.16 \mathrm{~Hz}, 2 \mathrm{H}), 7.45(\mathrm{t}, J=6.88 \mathrm{~Hz}, 2 \mathrm{H}), 7.37(\mathrm{t}, J=7.08 \mathrm{~Hz}, 2 \mathrm{H})$, 7.33-7.22 (m obstructed by solvent, $5 \mathrm{H}), 7.17(\mathrm{~d}, J=6.99 \mathrm{~Hz}, 2 \mathrm{H}), 6.94-6.91$ (overlapping d and $\mathrm{s}, J=\mathrm{Hz}, 3 \mathrm{H}) .{ }^{13} \mathrm{C}\left\{{ }^{1} \mathrm{H}\right\} \mathrm{NMR}\left(\mathrm{CDCl}_{3}, 126 \mathrm{MHz}\right): 143.49,139.98,134.18,131.93,130.02,128.91$, $128.67,127.92,127.52,126.68,126.40,125.64,125.48,124.28,49.67 \mathrm{ppm}$. This compound did not ionize well enough to acquire HRMS data.<smiles>c1ccc(C(c2ccccc2)c2ccc3ccccc3c2)cc1</smiles>

(2-naphthyl)diphenylmethane (6i). Following the general procedure above, a mixture of (2-naphthyl)(phenyl)methyl 2,3,4,5,6pentafluorobenzoate $(85.7 \mathrm{mg}, 0.200 \mathrm{mmol})$, phenyl boronic acid (36.6 $\mathrm{mg}, 0.300 \mathrm{mmol}), \mathrm{K}_{2} \mathrm{CO}_{3}(55.3 \mathrm{mg}, 0.400 \mathrm{mmol})$, and $\left(\eta^{3}-1-{ }^{\mathrm{t}} \mathrm{Bu}-\right.$ indenyl) $\mathrm{Pd}(\mathrm{IPr})(\mathrm{Cl})(1.4 \mathrm{mg}, 0.0020 \mathrm{mmol})$ in toluene $(1.6 \mathrm{~mL})$ and ethanol $(0.4 \mathrm{~mL})$ were stirred at $40{ }^{\circ} \mathrm{C}$ for $16 \mathrm{~h}$. Purification was performed using silica preparatory TLC with $100 \%$ hexanes to provide a white solid in a yield of $81 \%$ (47.4 $\mathrm{mg}) .{ }^{1} \mathrm{H}$ and ${ }^{13} \mathrm{C}$ NMR data were consistent with that published in the literature. ${ }^{16}$<smiles>c1ccc(C(c2ccccc2)c2ccccn2)cc1</smiles>

(2-pyridyl)diphenylmethane $(6 \mathbf{j})$. Following the general procedure above, a mixture of (2-pyridyl)(phenyl)methyl 2,3,4,5,6-pentafluorobenzoate (75.9 mg, $0.200 \mathrm{mmol}$ ), phenyl boronic acid $(36.6 \mathrm{mg}, 0.300 \mathrm{mmol}), \mathrm{K}_{2} \mathrm{CO}_{3}(55.3 \mathrm{mg}$, $0.400 \mathrm{mmol})$, and $\left(\eta^{3}-1-^{\mathrm{t}} \mathrm{Bu}-\mathrm{indenyl}^{\mathrm{P}} \mathrm{Pd}(\mathrm{IPr})(\mathrm{Cl})(5.6 \mathrm{mg}, 0.0080 \mathrm{mmol})\right.$ in toluene $(1.6 \mathrm{~mL})$ and water $(0.4 \mathrm{~mL})$ were stirred at $80{ }^{\circ} \mathrm{C}$ for $16 \mathrm{~h}$. Purification was performed using silica column chromatography with a 5\% EtOAc/95\% hexanes solvent mixture to provide a yellow oil in a yield of $49 \%(24.0 \mathrm{mg}) .{ }^{1} \mathrm{H}$ and ${ }^{13} \mathrm{C}$ NMR data were consistent with that published in the literature. ${ }^{14}$ 


\section{VI(B). Substrate scope for stereoselective Pd-catalyzed Suzuki-Miyaura reactions of chiral (diaryl)methyl pentafluorobenzoate and aryl boronic acids (Figure 7)}

The following general procedure was used for reactions between chiral (diaryl)methyl pentafluorobenzoate and aryl boronic acids. Control experiments using racemic substrates utilized the same procedure.

(Diaryl)methyl pentafluorobenzoate $(0.0500 \mathrm{mmol})$, 4-methoxyphenyl boronic acid $(0.0750$ $\mathrm{mmol})$, and $\mathrm{K}_{2} \mathrm{CO}_{3}(0.100 \mathrm{mmol})$ were added to a 1 dram vial equipped with a magnetic stir bar. $\left(\eta^{3}-1{ }^{-}{ }^{\mathrm{B} u}\right.$-indenyl $) \mathrm{Pd}(\mathrm{IPr})(\mathrm{Cl})(0.00050 \mathrm{mmol})$ (added as a stock solution in toluene), toluene $(0.4$ $\mathrm{mL})$ and ethanol $(0.1 \mathrm{~mL})$ were added in a glovebox. The vial was stirred at $40{ }^{\circ} \mathrm{C}$ for $4 \mathrm{~h}$ in a metal heating block on a hot plate fitted with a thermocouple. At this time, the vial was opened to air and the crude mixture was filtered through a silica plug and concentrated. Purification was performed using normal-phase preparatory TLC.

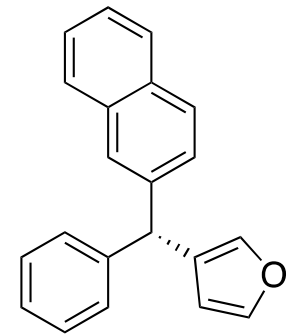

$(R)-(3-f u r y l)(2-n a p h t h y l)($ phenyl) methane (7a). Following the general procedure above, a mixture of (S)-(2-naphthyl)(phenyl)methyl 2,3,4,5,6pentafluorobenzoate $(21.4 \mathrm{mg}, 0.0500 \mathrm{mmol}), 3$-furyl boronic acid $(8.4 \mathrm{mg}$, $0.0750 \mathrm{mmol}), \quad \mathrm{K}_{2} \mathrm{CO}_{3} \quad(13.8 \mathrm{mg}, \quad 0.100 \mathrm{mmol})$, and $\left(\eta^{3}-1-^{\mathrm{t}} \mathrm{Bu}-\right.$ indenyl) $\mathrm{Pd}(\mathrm{IPr})(\mathrm{Cl})(0.35 \mathrm{mg}, 0.00050 \mathrm{mmol})$ in toluene $(0.4 \mathrm{~mL})$ and ethanol $(0.1 \mathrm{~mL})$ were stirred at $40^{\circ} \mathrm{C}$ for $16 \mathrm{~h}$. Purification was performed using silica preparatory TLC with $100 \%$ hexanes to provide a yellow solid in a yield of $97 \%$ (13.8 mg), $88 \%$ ee, 99\% es. Enantiomeric ratio was determined by HPLC analysis in comparison with a racemic sample (following the same procedure) using Chiralpak OD-H column, ambient temperature, 5\% $\mathrm{PrOH} / \mathrm{Hexanes,} 1.5 \mathrm{~mL} / \mathrm{min}$, major isomer: $3.160 \mathrm{~min}$, minor isomer: 3.466 min. $[\alpha]^{20} \mathrm{D}-23.25\left(\mathrm{c} 0.400, \mathrm{CHCl}_{3}\right) .{ }^{1} \mathrm{H}$ and ${ }^{13} \mathrm{C}$ NMR data were consistent with that published in the literature. ${ }^{3}$

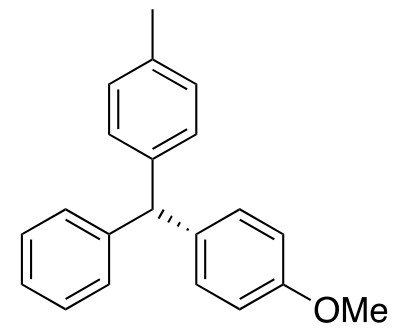

(R)-(4-methylphenyl)(4-methoxyphenyl)(phenyl) methane (7b). Following the general procedure above, a mixture of $(S)$-(4methylphenyl)(phenyl)methyl 2,3,4,5,6-pentafluorobenzoate (19.6 mg, $0.0500 \mathrm{mmol})$, 4-methoxyphenyl boronic acid (11.4 $\mathrm{mg}, 0.0750 \mathrm{mmol})$, $\mathrm{K}_{2} \mathrm{CO}_{3}$ (13.8 $\left.\mathrm{mg}, 0.100 \mathrm{mmol}\right)$, and $\left(\eta^{3}-1{ }^{\mathrm{t}} \mathrm{Bu}\right.$-indenyl) $\mathrm{Pd}(\mathrm{IPr})(\mathrm{Cl})(0.35$ $\mathrm{mg}, 0.00050 \mathrm{mmol})$ in toluene $(0.4 \mathrm{~mL})$ and ethanol $(0.1 \mathrm{~mL})$ were stirred with a $1 \%$ EtOAc/99\% PE solvent mixture to provide a white solid in a yield of $88 \%(12.6 \mathrm{mg})$, $76 \%$ ee, $90 \%$ es. Enantiomeric ratio was determined by HPLC analysis in comparison with a racemic sample (following the same procedure) using Chiralpak OD-H column, ambient temperature, $0.1 \%$ $\mathrm{PrOH} / \mathrm{Hexanes}, 0.8 \mathrm{~mL} / \mathrm{min}$, major isomer: $17.696 \mathrm{~min}$, minor isomer: 16.558 min. $[\alpha]^{20}-0.60\left(\mathrm{c} 1.000, \mathrm{CHCl}_{3}\right) .{ }^{1} \mathrm{H}$ and ${ }^{13} \mathrm{C}$ NMR data were consistent with that published in the literature. ${ }^{12}$ 


\section{VI(C). Substrate scope for Pd-catalyzed Suzuki-Miyaura reactions of (diphenyl)methyl pentafluorobenzoate and aryl boronic acids (Figure 8)}

The following general procedure was used for reactions between (diphenyl)methyl pentafluorobenzoate and aryl boronic acids.

(Diphenyl)methyl pentafluorobenzoate $(0.200 \mathrm{mmol})$, aryl boronic acid $(0.300 \mathrm{mmol})$, and $\mathrm{K}_{2} \mathrm{CO}_{3}$ (0.400 mmol) were added to a 1 dram vial equipped with a magnetic stir bar. $\left(\eta^{3}-1-\mathrm{Bu}-\right.$ indenyl) $\mathrm{Pd}(\mathrm{IPr})(\mathrm{Cl})(0.0020$ or $0.0080 \mathrm{mmol})$ (added as a stock solution in toluene), toluene (1.6 $\mathrm{mL})$ and ethanol $(0.4 \mathrm{~mL})$ were added in a glovebox. The vial was stirred at 40 or $80{ }^{\circ} \mathrm{C}$ for 4 or $16 \mathrm{~h}$ in a metal heating block on a hot plate fitted with a thermocouple. At this time, the vial was opened to air and the crude mixture was filtered through a silica plug and concentrated. Purification was performed using normal-phase column chromatography or preparatory TLC to provide the yield.

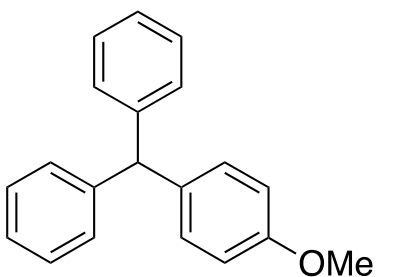

(4-methoxyphenyl)diphenylmethane $(8 \boldsymbol{b})$. Following the general procedure above, a mixture of (diphenyl)methyl 2,3,4,5,6pentafluorobenzoate $(75.7 \mathrm{mg}, 0.200 \mathrm{mmol})$, 4-methoxyphenyl boronic acid (45.6 mg, $0.300 \mathrm{mmol}), \mathrm{K}_{2} \mathrm{CO}_{3}(55.3 \mathrm{mg}, 0.400 \mathrm{mmol})$, and $\left(\eta^{3}-1-\right.$ ${ }^{\mathrm{t}} \mathrm{Bu}$-indenyl) $\mathrm{Pd}(\mathrm{IPr})(\mathrm{Cl})(1.4 \mathrm{mg}, 0.0020 \mathrm{mmol})$ in toluene $(1.6 \mathrm{~mL})$ and ethanol $(0.4 \mathrm{~mL})$ were stirred at $40{ }^{\circ} \mathrm{C}$ for $4 \mathrm{~h}$. Purification was performed using silica column chromatography with a gradient of 100\% PE to 20\% EtOAc/80\% PE solvent mixture to provide a colorless oil in a yield of $87 \%(47.5 \mathrm{mg}) .{ }^{1} \mathrm{H}$ and ${ }^{13} \mathrm{C}$ NMR data were consistent with that published in the literature. ${ }^{12}$

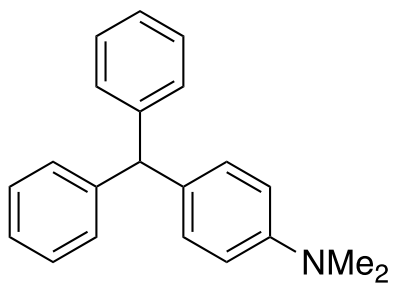

(4-dimethylaminophenyl)diphenylmethane ( $8 \mathrm{c}$ ). Following the general procedure above, a mixture of (diphenyl)methyl 2,3,4,5,6pentafluorobenzoate $(75.7 \mathrm{mg}, 0.200 \mathrm{mmol})$, 4-dimethylaminophenyl boronic acid (49.5 mg, $0.300 \mathrm{mmol}), \mathrm{K}_{2} \mathrm{CO}_{3}(55.3 \mathrm{mg}, 0.400 \mathrm{mmol})$, and $\left(\eta^{3}-1{ }^{\mathrm{t}} \mathrm{Bu}\right.$-indenyl $) \mathrm{Pd}(\mathrm{IPr})(\mathrm{Cl})(1.4 \mathrm{mg}, 0.0020 \mathrm{mmol})$ in toluene $(1.6$ $\mathrm{mL}$ ) and ethanol $(0.4 \mathrm{~mL})$ were stirred at $40{ }^{\circ} \mathrm{C}$ for $4 \mathrm{~h}$. Purification was performed using silica column chromatography with a $1 \%$ EtOAc/99\% PE solvent mixture to provide a beige solid in a yield of $96 \%(55.1 \mathrm{mg}) .{ }^{1} \mathrm{H}$ and ${ }^{13} \mathrm{C}$ NMR data were consistent with that published in the literature. ${ }^{12}$<smiles>Fc1ccc(C(c2ccccc2)c2ccccc2)cc1</smiles>

(4-fluorophenyl)diphenylmethane $(\mathbf{8 d})$. Following the general procedure above, a mixture of (diphenyl)methyl 2,3,4,5,6-pentafluorobenzoate (75.7 $\mathrm{mg}, 0.200 \mathrm{mmol})$, 4-fluorophenyl boronic acid (42.0 $\mathrm{mg}, 0.300 \mathrm{mmol})$, $\mathrm{K}_{2} \mathrm{CO}_{3}(55.3 \mathrm{mg}, 0.400 \mathrm{mmol})$, and $\left(\eta^{3}-1{ }^{-}{ }^{\mathrm{B}} \mathrm{Bu}\right.$-indenyl)Pd(IPr) $(\mathrm{Cl})(1.4 \mathrm{mg}$, $0.0020 \mathrm{mmol})$ in toluene $(1.6 \mathrm{~mL})$ and ethanol $(0.4 \mathrm{~mL})$ were stirred at 40

${ }^{\circ} \mathrm{C}$ for $4 \mathrm{~h}$. Purification was performed using silica column chromatography with $100 \%$ hexanes to provide a white solid in a yield of $94 \%(49.5 \mathrm{mg}) .{ }^{1} \mathrm{H}$ and ${ }^{13} \mathrm{C}$ NMR data were consistent with that published in the literature. ${ }^{12}$ 


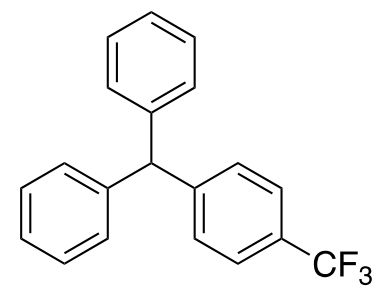

(4-trifluoromethylphenyl)diphenymethane (8e). Following the general procedure above, a mixture of (diphenyl)methyl 2,3,4,5,6pentafluorobenzoate $(75.7 \mathrm{mg}, 0.200 \mathrm{mmol})$, 4-trifluoromethylphenyl boronic acid (57.0 mg, $0.300 \mathrm{mmol}), \mathrm{K}_{2} \mathrm{CO}_{3}(55.3 \mathrm{mg}, 0.400 \mathrm{mmol})$, and $\left(\eta^{3}-1-^{\mathrm{t}} \mathrm{Bu}\right.$-indenyl $) \mathrm{Pd}(\mathrm{IPr})(\mathrm{Cl})(1.4 \mathrm{mg}, 0.0020 \mathrm{mmol})$ in toluene $(1.6 \mathrm{~mL})$ and ethanol $(0.4 \mathrm{~mL})$ were stirred at $40{ }^{\circ} \mathrm{C}$ for $4 \mathrm{~h}$. Purification was performed with a gradient of $100 \%$ hexanes to $5 \%$ EtOAc/95\% hexanes solvent mixture to provide a colorless oil in a yield of $90 \%(56.2 \mathrm{mg}) .{ }^{1} \mathrm{H}$ and ${ }^{13} \mathrm{C}$ NMR data were consistent with that published in the literature. ${ }^{12}$<smiles>COC(=O)c1ccc(C(c2ccccc2)c2ccccc2)cc1</smiles>

(4-methylesterphenyl)(diphenyl) methane (8f). Following the general procedure above, a mixture of (diphenyl)methyl 2,3,4,5,6pentafluorobenzoate $(75.7 \mathrm{mg}, 0.200 \mathrm{mmol})$, 4-methylesterphenyl boronic acid (54.0 mg, $0.300 \mathrm{mmol}), \mathrm{K}_{2} \mathrm{CO}_{3}(55.3 \mathrm{mg}, 0.400 \mathrm{mmol})$, and $\left(\eta^{3}-1-{ }^{t} \mathrm{Bu}\right.$-indenyl $) \mathrm{Pd}(\mathrm{IPr})(\mathrm{Cl})(1.4 \mathrm{mg}, 0.0020 \mathrm{mmol})$ in toluene $(1.6 \mathrm{~mL})$ and ethanol $(0.4 \mathrm{~mL})$ were stirred at $40{ }^{\circ} \mathrm{C}$ for $8 \mathrm{~h}$. Purification was performed using silica column chromatography with $5 \%$ EtOAc/95\% hexanes solvent mixture to provide a white solid in a yield of $87 \%(52.4 \mathrm{mg}) .{ }^{1} \mathrm{H}$ and ${ }^{13} \mathrm{C}$ NMR data were consistent with that published in the literature. ${ }^{14}$

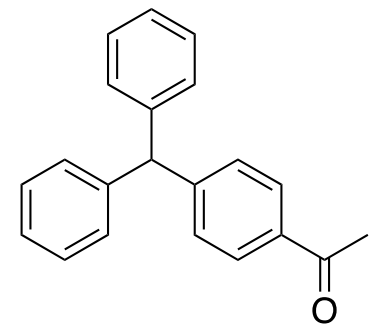

(4-acetylphenyl)diphenylmethane $(\mathbf{8 g})$. Following the general procedure above, a mixture of (diphenyl)methyl 2,3,4,5,6-pentafluorobenzoate (75.7 $\mathrm{mg}, 0.200 \mathrm{mmol})$, 4-acetylphenyl boronic acid (49.2 $\mathrm{mg}, 0.300 \mathrm{mmol})$, $\mathrm{K}_{2} \mathrm{CO}_{3}(55.3 \mathrm{mg}, 0.400 \mathrm{mmol})$, and $\left(\eta^{3}-1{ }^{t} \mathrm{Bu}-\right.$-indenyl $) \operatorname{Pd}(\mathrm{IPr})(\mathrm{Cl})(1.4$ $\mathrm{mg}, 0.0020 \mathrm{mmol})$ in toluene $(1.6 \mathrm{~mL})$ and ethanol $(0.4 \mathrm{~mL})$ were stirred at $40{ }^{\circ} \mathrm{C}$ for $4 \mathrm{~h}$. Purification was performed using silica preparatory TLC with a $1 \%$ EtOAc/99\% PE solvent mixture to provide a colorless oil at a yield of $70 \%(40.3 \mathrm{mg}) .{ }^{1} \mathrm{H}$ and ${ }^{13} \mathrm{C} \mathrm{NMR}$ data were consistent with that published in the literature. $^{12}$<smiles>N#Cc1ccc(C(c2ccccc2)c2ccccc2)cc1</smiles>

(4-cyanophenyl)diphenylmethane $(\mathbf{8 h})$. Following the general procedure above, a mixture of (diphenyl)methyl 2,3,4,5,6-pentafluorobenzoate (75.7 $\mathrm{mg}, 0.200 \mathrm{mmol})$, 4-cyanophenyl boronic acid (49.2 $\mathrm{mg}, 0.300 \mathrm{mmol}$ ), $\mathrm{K}_{2} \mathrm{CO}_{3}(55.3 \mathrm{mg}, 0.400 \mathrm{mmol})$, and $\left(\eta^{3}-1-^{\mathrm{t}} \mathrm{Bu}-\right.$-indenyl)Pd(IPr) $(\mathrm{Cl})(1.4 \mathrm{mg}$, $0.0020 \mathrm{mmol})$ in toluene $(1.6 \mathrm{~mL})$ and ethanol $(0.4 \mathrm{~mL})$ were stirred at $80{ }^{\circ} \mathrm{C}$ for $4 \mathrm{~h}$. Purification was performed using silica preparatory TLC with a $1 \%$ EtOAc/99\% hexanes solvent mixture to provide a yellow oil at a yield of $76 \%$ (40.9 $\mathrm{mg}) .{ }^{1} \mathrm{H}$ and ${ }^{13} \mathrm{C}$ NMR data were consistent with that published in the literature. ${ }^{17}$ 
<smiles>Cc1ccccc1C(c1ccccc1)c1ccccc1</smiles>

(2-methylphenyl)diphenylmethane (8i). Following the general procedure above, a mixture of (diphenyl)methyl 2,3,4,5,6-pentafluorobenzoate $(75.7 \mathrm{mg}$, $0.200 \mathrm{mmol}), 2$-methylphenyl boronic acid $(40.8 \mathrm{mg}, 0.300 \mathrm{mmol}), \mathrm{K}_{2} \mathrm{CO}_{3}$ (55.3 mg, $0.400 \mathrm{mmol})$, and $\left(\eta^{3}-1-^{\mathrm{t}} \mathrm{Bu}\right.$-indenyl $) \mathrm{Pd}(\mathrm{IPr})(\mathrm{Cl})(1.4 \mathrm{mg}, 0.0020$ $\mathrm{mmol})$ in toluene $(1.6 \mathrm{~mL})$ and ethanol $(0.4 \mathrm{~mL})$ were stirred at $40{ }^{\circ} \mathrm{C}$ for $8 \mathrm{~h}$. Purification was performed using silica column chromatography with $100 \%$ hexanes to provide a white solid in a yield of $74 \%(38.4 \mathrm{mg}) .{ }^{1} \mathrm{H}$ and ${ }^{13} \mathrm{C}$ NMR data were consistent with that published in the literature. ${ }^{12}$<smiles>c1ccc(C(c2ccccc2)c2cccc3ccccc23)cc1</smiles>

(1-naphthyl)diphenylmethane $(8 \mathrm{j})$. Following the general procedure above, a mixture of (diphenyl)methyl 2,3,4,5,6-pentafluorobenzoate $(75.7 \mathrm{mg}$, $0.200 \mathrm{mmol})$, 1-naphthyl boronic acid (51.6 mg, $0.300 \mathrm{mmol}), \mathrm{K}_{2} \mathrm{CO}_{3}(55.3$ $\mathrm{mg}, 0.400 \mathrm{mmol})$, and $\left(\eta^{3}-1{ }^{\mathrm{t}} \mathrm{Bu}\right.$-indenyl $) \mathrm{Pd}(\mathrm{IPr})(\mathrm{Cl})(1.4 \mathrm{mg}, 0.0020 \mathrm{mmol})$ in toluene $(1.6 \mathrm{~mL})$ and ethanol $(0.4 \mathrm{~mL})$ were stirred at $40{ }^{\circ} \mathrm{C}$ for $4 \mathrm{~h}$. Purification was performed using silica column chromatography with $100 \%$ hexanes to provide an off-white solid in a yield of $83 \%(48.7 \mathrm{mg}) .{ }^{1} \mathrm{H}$ and ${ }^{13} \mathrm{C} \mathrm{NMR}$ data were consistent with that published in the literature. ${ }^{16}$<smiles>c1ccc(C(c2ccccc2)c2ccc3ccccc3c2)cc1</smiles>

(2-naphthyl)diphenylmethane $(\mathbf{8 k})$. Following the general procedure above, a mixture of (diphenyl)methyl 2,3,4,5,6-pentafluorobenzoate (75.7 $\mathrm{mg}, 0.200 \mathrm{mmol}), 2$-naphthyl boronic acid (51.6 mg, $0.300 \mathrm{mmol}), \mathrm{K}_{2} \mathrm{CO}_{3}$ $(55.3 \mathrm{mg}, 0.400 \mathrm{mmol})$, and $\left(\eta^{3}-1-^{\mathrm{t}} \mathrm{Bu}\right.$-indenyl $) \mathrm{Pd}(\mathrm{IPr})(\mathrm{Cl})(1.4 \mathrm{mg}$, $0.0020 \mathrm{mmol})$ in toluene $(1.6 \mathrm{~mL})$ and ethanol $(0.4 \mathrm{~mL})$ were stirred at 40 ${ }^{\circ} \mathrm{C}$ for $4 \mathrm{~h}$. Purification was performed using silica preparatory TLC with $100 \%$ PE to provide a white solid in a yield of $80 \%(47.2 \mathrm{mg}) .{ }^{1} \mathrm{H}$ and ${ }^{13} \mathrm{C}$ NMR data were consistent with that published in the literature. ${ }^{16}$<smiles>COc1cccc(OC)c1C(c1ccccc1)c1ccccc1</smiles>

(2,6-dimethoxyphenyl)diphenylmethane $(8 \mathrm{l})$. Following the general procedure above, a mixture of (diphenyl)methyl 2,3,4,5,6pentafluorobenzoate $(75.7 \mathrm{mg}, 0.200 \mathrm{mmol}), 2,6$-dimethoxyphenyl boronic acid (54.6 mg, $0.300 \mathrm{mmol}), \mathrm{K}_{2} \mathrm{CO}_{3}(55.3 \mathrm{mg}, 0.400 \mathrm{mmol})$, and $\left(\eta^{3}-1-^{\mathrm{t}} \mathrm{Bu}-\right.$ indenyl $) \mathrm{Pd}(\mathrm{IPr})(\mathrm{Cl})(1.4 \mathrm{mg}, 0.0020 \mathrm{mmol})$ in toluene $(1.6 \mathrm{~mL})$ and ethanol $(0.4 \mathrm{~mL})$ were stirred at $40{ }^{\circ} \mathrm{C}$ for $16 \mathrm{~h}$. Purification was achieved by sonicating the crude solid with $1 \mathrm{M} \mathrm{KOH}(\mathrm{aq})$ for $15 \mathrm{~min}$., removing the aqueous layer, washing the solid with cold EtOAc, and drying in vacuo to provide a white solid in a yield of $57 \%(34.7 \mathrm{mg}) .{ }^{1} \mathrm{H}$ and ${ }^{13} \mathrm{C}$ NMR data were consistent with that published in the literature. ${ }^{18}$

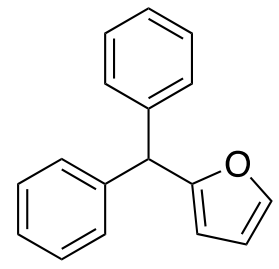

(2-furyl)diphenylmethane $(\mathbf{8 n})$. Following the general procedure above, a mixture of (diphenyl)methyl 2,3,4,5,6-pentafluorobenzoate $(75.7 \mathrm{mg}, 0.200$ mmol), 2-furyl boronic acid (33.6 mg, $0.300 \mathrm{mmol}), \mathrm{K}_{2} \mathrm{CO}_{3}(55.3 \mathrm{mg}, 0.400$ $\mathrm{mmol})$, and $\left(\eta^{3}-1{ }^{-} \mathrm{Bu}-\right.$-indenyl $) \mathrm{Pd}(\mathrm{IPr})(\mathrm{Cl})(1.4 \mathrm{mg}, 0.0020 \mathrm{mmol})$ in toluene $(1.6 \mathrm{~mL})$ and ethanol $(0.4 \mathrm{~mL})$ were stirred at $40{ }^{\circ} \mathrm{C}$ for $4 \mathrm{~h}$. Purification was performed using silica column chromatography with a gradient of $100 \%$ PE to 
$10 \%$ EtOAc/90\% PE solvent mixture to provide a yellow oil in a yield of $98 \%(45.8 \mathrm{mg}) .{ }^{1} \mathrm{H}$ and ${ }^{13} \mathrm{C}$ NMR data were consistent with that published in the literature. ${ }^{16}$

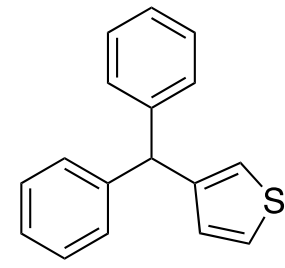

(3-thienyl)diphenylmethane (8o). Following the general procedure above, a mixture of (diphenyl)methyl 2,3,4,5,6-pentafluorobenzoate $(75.7 \mathrm{mg}, 0.200$ $\mathrm{mmol}$ ), 3-thienyl boronic acid (38.4 mg, $0.300 \mathrm{mmol}), \mathrm{K}_{2} \mathrm{CO}_{3}(55.3 \mathrm{mg}, 0.400$ $\mathrm{mmol})$, and $\left(\eta^{3}-1-^{\mathrm{t}} \mathrm{Bu}-\mathrm{indenyl}\right) \mathrm{Pd}(\mathrm{IPr})(\mathrm{Cl})(1.4 \mathrm{mg}, 0.0020 \mathrm{mmol})$ in toluene $(1.6 \mathrm{~mL})$ and ethanol $(0.4 \mathrm{~mL})$ were stirred at $40{ }^{\circ} \mathrm{C}$ for $4 \mathrm{~h}$. Purification was performed using silica column chromatography with a gradient of $100 \%$ PE to $10 \%$ EtOAc/90\% PE solvent mixture to provide an off-white solid in a yield of $97 \%$ (48.7 mg). ${ }^{1} \mathrm{H}$ and ${ }^{13} \mathrm{C}$ NMR data were consistent with that published in the literature. ${ }^{12}$

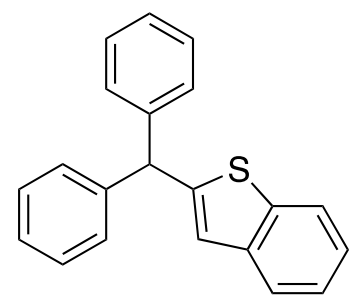

(benzo[b]thien-2-yl)diphenylmethane (8p). Following the general procedure above, a mixture of (diphenyl)methyl 2,3,4,5,6pentafluorobenzoate $(75.7 \mathrm{mg}, 0.200 \mathrm{mmol})$, Benzo[b]thien-2-yl boronic acid (53.4 mg, $0.300 \mathrm{mmol}), \mathrm{K}_{2} \mathrm{CO}_{3}(55.3 \mathrm{mg}, 0.400 \mathrm{mmol})$, and $\left(\eta^{3}-1-^{\mathrm{t}} \mathrm{Bu}-\right.$ indenyl) $\mathrm{Pd}(\mathrm{IPr})(\mathrm{Cl})(1.4 \mathrm{mg}, 0.0020 \mathrm{mmol})$ in toluene $(1.6 \mathrm{~mL})$ and ethanol $(0.4 \mathrm{~mL})$ were stirred at $40{ }^{\circ} \mathrm{C}$ for $16 \mathrm{~h}$. Purification was performed using silica column chromatography with a gradient of $100 \%$ hexanes to $5 \%$ EtOAc/95\% hexanes solvent mixture to provide an off-white solid in a yield of $80 \%(47.8 \mathrm{mg}) .{ }^{1} \mathrm{H}$ and ${ }^{13} \mathrm{C}$ NMR data were consistent with that published in the literature. ${ }^{19}$<smiles></smiles>

(N-Boc-2-pyrrole)diphenylmethane $(\mathbf{8 q})$. Following the general procedure above, a mixture of (diphenyl)methyl 2,3,4,5,6-pentafluorobenzoate (75.7 mg, $0.200 \mathrm{mmol}), N$-Boc-2-pyrrole boronic acid $(63.3 \mathrm{mg}, 0.300 \mathrm{mmol}), \mathrm{K}_{2} \mathrm{CO}_{3}$ (55.3 mg, $0.400 \mathrm{mmol})$, and $\left(\eta^{3}-1{ }^{-} \mathrm{Bu}-\right.$-indenyl $) \mathrm{Pd}(\mathrm{IPr})(\mathrm{Cl})(1.4 \mathrm{mg}, 0.0020$ $\mathrm{mmol})$ in toluene $(1.6 \mathrm{~mL})$ and ethanol $(0.4 \mathrm{~mL})$ were stirred at $40{ }^{\circ} \mathrm{C}$ for $16 \mathrm{~h}$. Purification was performed using silica column chromatography with a $1 \%$ EtOAc/99\% hexanes solvent mixture to provide an yellow oil in a yield of $70 \%(46.4 \mathrm{mg}) .{ }^{1} \mathrm{H}$ NMR $\left(\mathrm{CDCl}_{3}, 600 \mathrm{MHz}\right): 7.32(\mathrm{~m}, 1 \mathrm{H}), 7.27$ (t obstructed by solvent, $\left.J=7.48 \mathrm{~Hz}, 4 \mathrm{H}\right), 7.21$ (t, $J$ $=7.18 \mathrm{~Hz}, 2 \mathrm{H}), 7.06(\mathrm{~d}, J=6.92 \mathrm{~Hz}, 4 \mathrm{H}), 6.08(\mathrm{t}, J=3.48 \mathrm{~Hz}, 1 \mathrm{H}), 6.06(\mathrm{~s}, 1 \mathrm{H}), 5.55$ (br. s, 1H), $1.36 \mathrm{ppm}(\mathrm{s}, 9 \mathrm{H}) .{ }^{13} \mathrm{C}\left\{{ }^{1} \mathrm{H}\right\} \mathrm{NMR}\left(\mathrm{CDCl}_{3}, 151 \mathrm{MHz}\right): 149.43,143.78,136.96,129.22,128.29$, 126.41, 122.25, 115.54, 109.76, 83.85, 50.37, 27.78 ppm. This compound did not ionize well enough to acquire HRMS data. 
VI(D). Procedure for determination of NMR yields in substrate scopes (see VI(A, B, and C).

The following general procedure was used to determine NMR yields for reactions between (diaryl)methyl 2,3,4,5,6-pentafluorobenzoate and aryl boronic acids. Catalyst loading, reagent equiv., temperature, and time areas described in $\mathbf{V I}(\mathbf{A}, \mathbf{B}$, and $\mathbf{C})$.

(Diaryl)methyl pentafluorobenzoate ( $0.0500 \mathrm{mmol}, 1$ equiv.), aryl boronic acid $(0.0750 \mathrm{mmol}, 1.5$ equiv.), $\mathrm{K}_{2} \mathrm{CO}_{3}\left(0.100 \mathrm{mmol}, 2\right.$ equiv.), and $\left(\eta^{3}-1-{ }^{\mathrm{t}} \mathrm{Bu}-\mathrm{indenyl}\right) \mathrm{Pd}(\mathrm{IPr})(\mathrm{Cl})(0.00050$ or 0.0020 $\mathrm{mmol}$, added as a stock solution in toluene, 1 or $4 \mathrm{~mol} \%$ ) were added to a 1 dram vial equipped with a magnetic stir bar. Toluene $(0.4 \mathrm{~mL})$ and ethanol or water $(0.1 \mathrm{~mL})$ were added in a glovebox. The vial was stirred at 40 or $80^{\circ} \mathrm{C}$ for 4 or $16 \mathrm{~h}$ in a metal heating block on a hot plate fitted with a thermocouple. At this time, the vial was opened to air, filtered through a silica plug, and concentrated. A ${ }^{1} \mathrm{H}$ NMR spectrum was recorded in $\mathrm{CDCl}_{3}$ to determine the yield relative to hexamethylbenzene internal standard. 
VI(E). Boronic acids that were not compatible with our reaction:
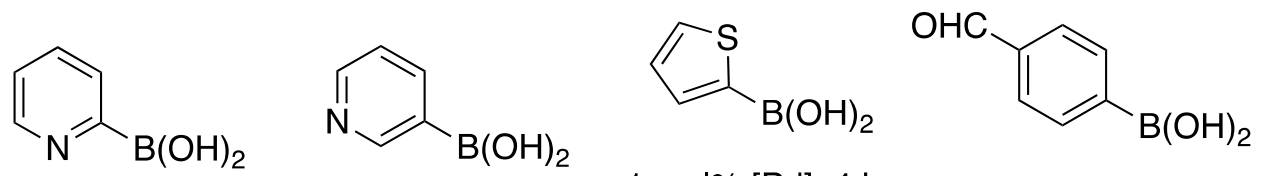

$1 \mathrm{~mol} \%$ [Pd], $4 \mathrm{~h} 1 \mathrm{~mol} \%$ [Pd], $4 \mathrm{~h}, 80$ 13\%; $16 \mathrm{~h} 27 \%$ $<1 \%$ NMR yield $\quad{ }^{\circ} \mathrm{C}<1 \%$ NMR yield NMR yield desired desired product desired product product

$1 \mathrm{~mol} \%$ [Pd], $4 \mathrm{~h}$ $<1 \%$ NMR yield desired product<smiles>CC(C)[B]O</smiles><smiles>[Y][B-]C(C)C</smiles>

$1 \mathrm{~mol} \%$ [Pd], $4 \mathrm{~h}$ $<1 \%$ NMR yield desired product

$1 \mathrm{~mol} \%$ [Pd], $4 \mathrm{~h}$ $<1 \%$ NMR yield desired product<smiles>Oc1ccc(Cl)cc1</smiles><smiles>Clc1ccc(-c2ccc(C(c3ccccc3)c3ccccc3)cc2)cc1</smiles>

$1 \mathrm{~mol} \%$ [Pd], $16 \mathrm{~h}$ $29 \%$ NMR yield $20 \%$ desired product 


\section{Synthesis of oxidative addition complexes from (IPr)Pd(styrene) 2 and esters.}

$(\mathrm{IPr}) \mathrm{Pd}\left(\text { styrene }_{2} \text {. (IPr)Pd(styrene }\right)_{2}$ was synthesized using a modified literature procedure. ${ }^{20}$ $\left(\eta^{3}\right.$ allyl $) \mathrm{Pd}(\mathrm{IPr})(\mathrm{Cl})(0.500 \mathrm{~g}, 0.873 \mathrm{mmol})$ and dry $\mathrm{KO}^{t} \mathrm{Bu}(0.980 \mathrm{~g}, 8.73 \mathrm{mmol})$ were added to a $250 \mathrm{~mL}$ Schlenk flask in a dinitrogen glovebox. The Schlenk flask was sealed and moved to a Schlenk line where methanol $(10 \mathrm{~mL})$ and styrene $(2.00 \mathrm{~mL}, 17.5 \mathrm{mmol})$ were added under a dinitrogen flow. The reaction was stirred at room temperature for 1 hour. At this time, under dinitrogen flow, the reaction mixture was filtered using a cannula filter and the solid washed with water and methanol. Toluene was cannula transferred into the flask to dissolve the solid, the solution was cannula filtered into a clean Schlenk flask, and the solvent removed in vacuo. The solid was washed with hexanes, and dried in vacuo resulting in a beige solid in a yield of $60 \%$ (365.4 mg). ${ }^{1} \mathrm{H}$ NMR data was consistent with that published in the literature. ${ }^{20}$

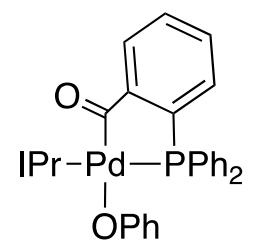

$(\mathrm{IPr}) \mathrm{Pd}\left(\mathrm{C}(\mathrm{O})\left(2-\mathrm{PPh}_{2}-\mathrm{C}_{6} \mathrm{H}_{4}\right)(\mathrm{OPh}) \text { (Figure 9, compound 1). (IPr)Pd(styrene) }\right)_{2}$ (20 mg, $0.028 \mathrm{mmol}), 2$-(diphenylphosphino)benzoate (16 $\mathrm{mg}, 0.043 \mathrm{mmol}$ ), and toluene $(0.5 \mathrm{~mL})$ were added to a 1 dram vial with a stir bar and stirred for $24 \mathrm{~h}$ at room temperature. At this time pentane was added and the reaction mixture stored at $4{ }^{\circ} \mathrm{C}$, which caused the precipitation of a yellow solid. The solid was filtered, washed with pentane, and dried in vacuo to provide 1 in a yield of $75 \%$ (19 mg) ${ }^{1} \mathrm{H}$ NMR ( $\left.\mathrm{C}_{6} \mathrm{D}_{6}, 400 \mathrm{MHz}\right): 7.84(\mathrm{~d}, J=7.79 \mathrm{~Hz}, 1 \mathrm{H}), 7.31-7.27$ (m, 4H), 7.20-7.10 (m obstructed by solvent, 7H), 6.97-6.91(m, 7H), 6.79-6.76 (m, 3H), $6.66(\mathrm{t}, J=7.48 \mathrm{~Hz}, 2 \mathrm{H}), 6.33$ $(\mathrm{t}, J=6.97 \mathrm{~Hz}, 1 \mathrm{H}), 6.00(\mathrm{~d}, J=7.89 \mathrm{~Hz}, 2 \mathrm{H}), 3.86$ (br m, 2H), 3.47 (br m, 2H), $1.38(\mathrm{~d}, J=6.22$ $\mathrm{Hz}, 12 \mathrm{H}), 1.11 \mathrm{ppm}$ (br m, $12 \mathrm{H}) .{ }^{13} \mathrm{C}\left\{{ }^{1} \mathrm{H}\right\}$ NMR $\left(\mathrm{C}_{6} \mathrm{D}_{6}, 101 \mathrm{MHz}\right): 220.87,189.21,188.37,172.29$, 156.29 , 155.90, 139.62, 139.35, 136.82, 134.06, 133.98, 132.06, 132.01, 131.98, 131.78, 131.46, $131.26,130.00,129.91,128.36,124.27,123.75,123.63,123.33,121.52,111.58,28.93,28.42$, 26.58, 24.31, 22.57. ${ }^{31} \mathrm{P}\left\{{ }^{1} \mathrm{H}\right\}$ NMR $\left(\mathrm{C}_{6} \mathrm{D}_{6}, 162 \mathrm{MHz}\right): 50.38 \mathrm{ppm}$. IR $\left(\mathrm{cm}^{-1}\right) 2961.7,1632.6$, 1584.8, 1474.6, 1455.2, 1437.0, 1405.7, 1292.9, 1170.4, 1157.7, 1122.0, 986.7, 868.3, 751.8, 740.8, 691.1. Elemental analysis: Found (Calcd) for $\mathrm{C}_{52} \mathrm{H}_{55} \mathrm{~N}_{2} \mathrm{O}_{2} \mathrm{PPd}$ : C 70.45 (71.18); H 6.43 (6.32); N 3.09 (3.19).

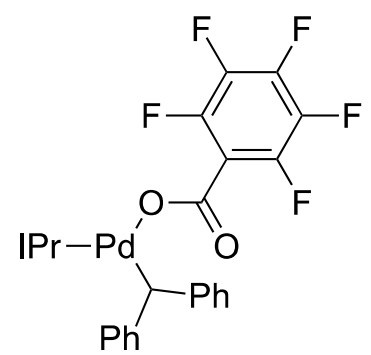

$(\mathrm{IPr}) \mathrm{Pd}\left(\mathrm{OOCC}_{6} \mathrm{~F}_{5}\right)\left(\mathrm{CHPh}_{2}\right)$ (Scheme 1, compound 2). (IPr)Pd(styrene $)_{2}$ (20 mg, $0.028 \mathrm{mmol}$ ) and diphenylmethyl 2,3,4,5,6-pentafluorobenzoate (16 mg, $0.043 \mathrm{mmol}$ ) were added to a $J$-Young NMR tube with $0.50 \mathrm{~mL}$ $\mathrm{C}_{6} \mathrm{D}_{6}$. After leaving the reaction mixture for $24 \mathrm{~h}$ at room temperature and $4 \mathrm{~h}$ at $40{ }^{\circ} \mathrm{C}$, pentane $(2 \mathrm{~mL})$ was added. The reaction was cooled at $4{ }^{\circ} \mathrm{C}$ and yellow precipitate formed, which was collected via filtration and washed with pentane. The resulting solid was dissolved in toluene, filtered, and concentrated in vacuo to give 2 as a yellow solid in a yield of $65 \%$ (16 mg). ${ }^{1} \mathrm{H}$ NMR $\left(\mathrm{C}_{6} \mathrm{D}_{6}, 600 \mathrm{MHz}\right): 7.29(\mathrm{t}, J=7.81 \mathrm{~Hz}, 2 \mathrm{H}), 7.14-7.10(\mathrm{~m}, 8 \mathrm{H}), 7.06(\mathrm{t}, J=7.33$ $\mathrm{Hz}, 2 \mathrm{H}), 7.03$ (d, J = 7.04 Hz, 4H), $6.50(\mathrm{~s}, 2 \mathrm{H}), 4.78(\mathrm{~s}, 2 \mathrm{H}), 2.91$ (sept, $J=6.79 \mathrm{~Hz}, 4 \mathrm{H}), 1.16$ $(\mathrm{d}, J=6.69 \mathrm{~Hz}, 12 \mathrm{H}), 1.01 \mathrm{ppm}(\mathrm{d}, J=6.84 \mathrm{~Hz}, 12 \mathrm{H}) .{ }^{13} \mathrm{C}\left\{{ }^{1} \mathrm{H}\right\} \mathrm{NMR}\left(\mathrm{C}_{6} \mathrm{D}_{6}, 151 \mathrm{MHz}\right): 177.04$, 164.70, 146.06, 136.08, 135.76, 130.35, 130.21, 128.35, 126.07, 124.80, 124.59, 123.98, 43.56, 29.06, 25.95, $22.66 \mathrm{ppm} .{ }^{19} \mathrm{~F}$ NMR $\left(\mathrm{C}_{6} \mathrm{D}_{6}, 376 \mathrm{MHz}\right):-139.62(\mathrm{dd}, J=24.23,8.49 \mathrm{~Hz}, 2 \mathrm{~F})-158.24$ $(\mathrm{t}, 21.23,1 \mathrm{~F}),-164.47 \mathrm{ppm}(\mathrm{td}, J=24.16,5.51 \mathrm{~Hz}, 2 \mathrm{~F}) . \mathrm{IR}\left(\mathrm{cm}^{-1}\right): 2964.3,1644.7,1632.7,1514.7$, $1488.3,1342.5,1099.7,987.2,804.1,748.7,698.5,675.7$. Due to the instability of this complex 
we did not obtain elemental analysis. Specifically, in the absence of excess ester, the product (compound 2) decomposes on standing in $\mathrm{C}_{6} \mathrm{D}_{6}$ solution at room temperature in 8 hours.<smiles>Cc1ccccc1C(OC(=O)c1c(F)c(F)c(F)c(F)c1F)[Pb](c1ccccc1)C(C)C</smiles>

$(\mathrm{IPr}) \mathrm{Pd}\left(\mathrm{OOCC}_{6} \mathrm{~F}_{5}\right)(\mathrm{CH}(2-\mathrm{MePh}) \mathrm{Ph})$. (IPr)Pd(styrene $)_{2}(20 \mathrm{mg}, 0.0284$ $\mathrm{mmol}$ ) and (2-methylphenyl)(phenyl)methyl 2,3,4,5,6pentafluorobenzoate $(17 \mathrm{mg}, 0.0426 \mathrm{mmol})$ were added to a $J$-Young NMR tube with $0.50 \mathrm{~mL} \mathrm{C}{ }_{6} \mathrm{D}_{6}$. After leaving the reaction mixture for $24 \mathrm{~h}$ at room temperature and $4 \mathrm{~h}$ at $40{ }^{\circ} \mathrm{C}$, pentane $(2 \mathrm{~mL})$ was added. The reaction was cooled at $4{ }^{\circ} \mathrm{C}$ and yellow precipitate formed, which was collected via filtration and washed with pentane. The solid was dissolved in toluene, filtered, and concentrated in vacuo to give a yellow solid in a yield of $55 \%(13.8 \mathrm{mg}) .{ }^{1} \mathrm{H}$ NMR $\left(\mathrm{C}_{6} \mathrm{D}_{6}, 400 \mathrm{MHz}\right): 7.66(\mathrm{~d}, J=7.56 \mathrm{~Hz}, 1 \mathrm{H}), 7.54(\mathrm{t}, J=7.37$ $\mathrm{Hz}, 1 \mathrm{H}), 7.30(\mathrm{t}, J=7.73 \mathrm{~Hz}, 2 \mathrm{H}), 7.22(\mathrm{~d}, J=6.26 \mathrm{~Hz}, 2 \mathrm{H}), 7.10(\mathrm{t}, J=6.84 \mathrm{~Hz}, 1 \mathrm{H}), 7.00-6.96$ $(\mathrm{m}, 6 \mathrm{H}), 6.87(\mathrm{~d}, J=5.87 \mathrm{~Hz}, 2 \mathrm{H}), 6.49(\mathrm{~s}, 2 \mathrm{H}), 5.06(\mathrm{~s}, 1 \mathrm{H}), 3.21(\mathrm{sep}, J=6.75 \mathrm{~Hz}, 2 \mathrm{H}), 2.61$ (sep, $J=6.84 \mathrm{~Hz}, 2 \mathrm{H}), 1.40$ (s, 3H), $1.18(\mathrm{~d}, J=6.67 \mathrm{~Hz}, 6 \mathrm{H}), 1.04-0.97$ ppm (3 overlapping d, 18H). ${ }^{13} \mathrm{C}\left\{{ }^{1} \mathrm{H}\right\}$ NMR $\left(\mathrm{C}_{6} \mathrm{D}_{6}, 101 \mathrm{MHz}\right): 179.62,161.88,146.67,145.42,140.31,135.80,133.55,133.25$, 131.80, 130.46, 129.12, 127.58, 127.30, 125.47, 125.16, 124.95, 124.36, 123.93, 105.91, 44.06, 28.91, 28.85, 26.17, 25.52, 23.07, 22.62, 19.19 ppm. ${ }^{19} \mathrm{~F} \mathrm{NMR}\left(\mathrm{C}_{6} \mathrm{D}_{6}, 376 \mathrm{MHz}\right):-139.20(\mathrm{dd}, J=$ $15.82,8.67 \mathrm{~Hz}, 2 \mathrm{~F}),-159.23(\mathrm{t}, 21.15,1 \mathrm{~F}),-164.79 \mathrm{ppm}(\mathrm{td}, J=21.23,5.55 \mathrm{~Hz}, 2 \mathrm{~F}) . \mathrm{IR}\left(\mathrm{cm}^{-1}\right)$ 2963.1, 1644.1, 1634.1, 1515.6, 1487.9, 1456.0, 1344.7, 1327.2, 1098.2, 988.6, 802.4, 750.0, 695.5. Due to the instability of this complex we did not obtain elemental analysis. Specifically, in the absence of excess ester, the product decomposes on standing in $\mathrm{C}_{6} \mathrm{D}_{6}$ solution at room temperature in 8 hours. 
VIII. Comparing rates of oxidative addition of diphenylmethyl- and (2methylphenyl)(phenyl)methyl-2,3,4,5,6-pentafluorobenzoate (Figure 14)

(IPr)Pd(styrene $)_{2}(5 \mathrm{mg}, 0.007 \mathrm{mmol})$, diarylmethyl 2,3,4,5,6-pentafluorobenzoate $(0.007 \mathrm{mmol})$, and 1,2,3-trimethoxybenzene $(0.6 \mathrm{mg}, 0.004 \mathrm{mmol})$ internal standard (as stock solutions) were added to a $J$-Young NMR tube with $0.5 \mathrm{~mL} \mathrm{C} \mathrm{C}_{6} \mathrm{D}_{6}$ and monitored over time using ${ }^{1} \mathrm{H}$ NMR spectroscopy. The data is shown in Figure 14. 


\section{X-ray crystallographic data for compound 1.}

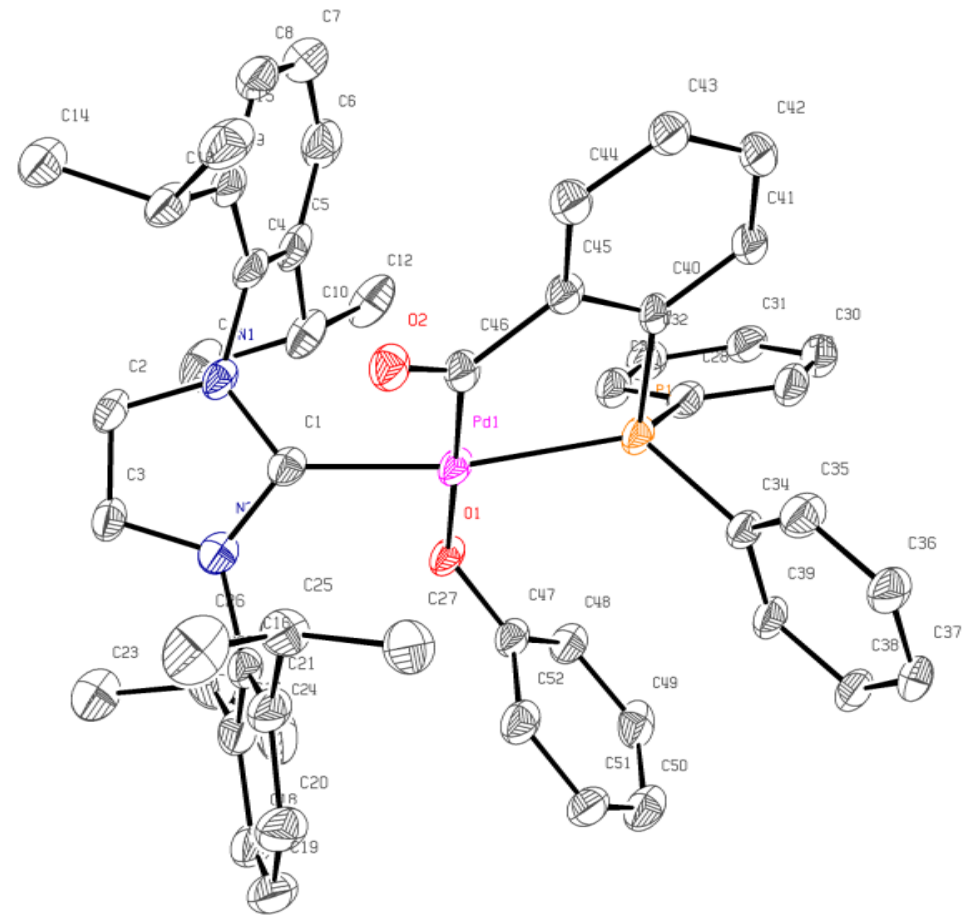

Figure S1. Numbering scheme of compound 1 with $30 \%$ thermal ellipsoid probability levels. The hydrogen atoms are omitted for clarity.

Table S2. Crystal data and structure refinement for compound 1.

Empirical formula

Formula weight

Temperature

Wavelength

Crystal system

Space group

Unit cell dimensions

Volume

Z

Density (calculated)

Absorption coefficient

$\mathrm{F}(000)$

Crystal size

Crystal color and habit

Diffractometer

images

Theta range for data collection

Index ranges

Reflections collected

Independent reflections

Observed reflections (I > 2sigma(I))

Completeness to theta $=67.684^{\circ}$
C104 H110 N4 O4 P2 Pd2

1754.69

293(2) K

$1.54184 \AA$

Triclinic

P-1

$\mathrm{a}=12.4427(5) \AA$

$\alpha=78.885(4)^{\circ}$.

$\beta=69.013(4)^{\circ}$.

$\mathrm{b}=13.4487(5) \AA$

$\mathrm{c}=15.5459(7) \AA$

2382.68(18) $\AA^{3}$

1

$1.223 \mathrm{Mg} / \mathrm{m}^{3}$

$3.756 \mathrm{~mm}^{-1}$

916

$0.1 \times 0.1 \times 0.05 \mathrm{~mm}^{3}$

yellow block

dtrek-CrysAlisPro-abstract goniometer imported rigaku-d*trek

3.100 to $68.401^{\circ}$.

$-14<=\mathrm{h}<=14,-16<=\mathrm{k}<=16,-18<=1<=18$

83976

$8536[\mathrm{R}(\mathrm{int})=0.0953]$

7016

$98.2 \%$ 
Absorption correction

Max. and min. transmission

Solution method

Refinement method

Data / restraints / parameters

Goodness-of-fit on $\mathrm{F}^{2}$

Final $R$ indices [I>2sigma(I)]

$\mathrm{R}$ indices (all data)

Extinction coefficient

Largest diff. peak and hole
Semi-empirical from equivalents

1.00000 and 0.61398

ShelXT (Sheldrick, 2015)

ShelXL (Sheldrick, 2015)

8536 / 0 / 531

1.041

$\mathrm{R} 1=0.0830, \mathrm{wR} 2=0.2129$

$\mathrm{R} 1=0.0984, \mathrm{wR} 2=0.2264$

$\mathrm{n} / \mathrm{a}$

3.096 and -1.229 e. $\AA^{-3}$

Table S3. Atomic coordinates $\left(\times 10^{4}\right)$ and equivalent isotropic displacement parameters $\left(\AA^{2} \times 10^{3}\right)$ for compound $\mathbf{1}$. $\mathrm{U}(\mathrm{eq})$ is defined as one third of the trace of the orthogonalized $\mathrm{U}^{\mathrm{ij}}$ tensor.

\begin{tabular}{|c|c|c|c|c|}
\hline & $\mathrm{x}$ & $\mathrm{y}$ & $\mathrm{z}$ & $\mathrm{U}(\mathrm{eq})$ \\
\hline $\operatorname{Pd}(1)$ & $1844(1)$ & $2673(1)$ & $7158(1)$ & $38(1)$ \\
\hline $\mathrm{P}(1)$ & $2860(1)$ & 1594(1) & $6200(1)$ & $39(1)$ \\
\hline $\mathrm{O}(1)$ & 441(4) & $2812(3)$ & $6689(4)$ & $44(1)$ \\
\hline $\mathrm{O}(2)$ & $3182(4)$ & $2798(4)$ & $8296(4)$ & $46(1)$ \\
\hline $\mathrm{N}(1)$ & $1644(5)$ & $4739(4)$ & $7786(4)$ & $40(1)$ \\
\hline $\mathrm{N}(2)$ & $193(5)$ & $3776(4)$ & $8678(4)$ & $41(1)$ \\
\hline $\mathrm{C}(45)$ & $4315(6)$ & $2217(5)$ & $6932(5)$ & $41(2)$ \\
\hline $\mathrm{C}(2)$ & $956(6)$ & $5277(5)$ & $8452(5)$ & $44(2)$ \\
\hline $\mathrm{C}(3)$ & $54(6)$ & $4679(5)$ & $9013(6)$ & $45(2)$ \\
\hline $\mathrm{C}(40)$ & $4293(5)$ & $1765(4)$ & $6204(5)$ & $39(2)$ \\
\hline$C(46)$ & $3186(6)$ & $2588(5)$ & $7563(5)$ & $42(2)$ \\
\hline$C(37)$ & $2318(7)$ & $-1873(5)$ & $6895(5)$ & $50(2)$ \\
\hline $\mathrm{C}(28)$ & $2946(6)$ & 1889(5) & $4988(5)$ & $42(2)$ \\
\hline $\mathrm{C}(41)$ & $5322(6)$ & $1426(5)$ & $5602(6)$ & $46(2)$ \\
\hline$C(36)$ & $3194(7)$ & $-1445(5)$ & $7050(6)$ & $55(2)$ \\
\hline $\mathrm{C}(33)$ & $2452(6)$ & $2780(5)$ & $4680(6)$ & $47(2)$ \\
\hline $\mathrm{C}(44)$ & $5357(6)$ & $2295(5)$ & $7079(6)$ & $49(2)$ \\
\hline $\mathrm{C}(47)$ & $-86(6)$ & 1963(5) & $6686(5)$ & $42(2)$ \\
\hline$C(35)$ & $3361(7)$ & $-415(5)$ & $6861(6)$ & $51(2)$ \\
\hline $\mathrm{C}(1)$ & $1185(6)$ & $3796(5)$ & $7934(5)$ & $39(1)$ \\
\hline $\mathrm{C}(38)$ & $1589(7)$ & $-1253(5)$ & $6550(6)$ & $49(2)$ \\
\hline$C(34)$ & $2644(6)$ & $223(5)$ & $6488(5)$ & $40(1)$ \\
\hline $\mathrm{C}(9)$ & $3609(6)$ & $5370(5)$ & $7309(6)$ & $49(2)$ \\
\hline $\mathrm{C}(43)$ & $6345(6)$ & $1935(5)$ & $6495(6)$ & $48(2)$ \\
\hline $\mathrm{C}(13)$ & $3561(7)$ & $5175(5)$ & $8317(6)$ & $51(2)$ \\
\hline $\mathrm{C}(42)$ & $6337(6)$ & $1515(5)$ & $5747(6)$ & $49(2)$ \\
\hline $\mathrm{C}(4)$ & $2680(6)$ & $5175(4)$ & $7051(5)$ & $44(2)$ \\
\hline$C(16)$ & $-642(6)$ & $2957(5)$ & $9140(5)$ & $41(2)$ \\
\hline$C(39)$ & 1741(6) & $-206(5)$ & $6348(5)$ & $46(2)$ \\
\hline $\mathrm{C}(5)$ & $2713(7)$ & $5429(5)$ & $6125(6)$ & $54(2)$ \\
\hline $\mathrm{C}(52)$ & $-500(6)$ & $1205(5)$ & $7496(6)$ & $51(2)$ \\
\hline$C(17)$ & $-1661(6)$ & $3040(6)$ & $8934(6)$ & $52(2)$ \\
\hline $\mathrm{C}(31)$ & $3105(6)$ & $2421(6)$ & $3116(6)$ & $52(2)$ \\
\hline $\mathrm{C}(14)$ & $3437(7)$ & $6184(6)$ & $8671(6)$ & $57(2)$ \\
\hline$C(27)$ & $1224(8)$ & $1088(6)$ & $9779(7)$ & $68(2)$ \\
\hline $\mathrm{C}(48)$ & $-275(6)$ & $1833(5)$ & $5888(6)$ & $48(2)$ \\
\hline$C(25)$ & $682(6)$ & $2106(6)$ & $9962(6)$ & $51(2)$ \\
\hline$C(30)$ & $3580(7)$ & $1529(6)$ & $3421(6)$ & $53(2)$ \\
\hline $\mathrm{C}(29)$ & $3488(6)$ & $1261(5)$ & $4341(6)$ & $49(2)$ \\
\hline
\end{tabular}




\begin{tabular}{lrrrr}
$\mathrm{C}(50)$ & $-1214(7)$ & $194(6)$ & $6690(7)$ & $63(2)$ \\
$\mathrm{C}(49)$ & $-800(7)$ & $942(6)$ & $5866(7)$ & $56(2)$ \\
$\mathrm{C}(8)$ & $4604(7)$ & $5811(6)$ & $6589(7)$ & $62(2)$ \\
$\mathrm{C}(6)$ & $3736(8)$ & $5845(6)$ & $5447(6)$ & $62(2)$ \\
$\mathrm{C}(51)$ & $-1053(7)$ & $345(6)$ & $7470(7)$ & $56(2)$ \\
$\mathrm{C}(12)$ & $1912(10)$ & $5378(6)$ & $4846(6)$ & $70(3)$ \\
$\mathrm{C}(22)$ & $-1844(7)$ & $3901(7)$ & $8214(6)$ & $61(2)$ \\
$\mathrm{C}(10)$ & $1635(8)$ & $5288(5)$ & $5887(6)$ & $58(2)$ \\
$\mathrm{C}(18)$ & $-2510(7)$ & $2298(7)$ & $9452(7)$ & $66(2)$ \\
$\mathrm{C}(21)$ & $-445(7)$ & $2198(6)$ & $9797(6)$ & $56(2)$ \\
$\mathrm{C}(32)$ & $2536(7)$ & $3035(6)$ & $3750(6)$ & $54(2)$ \\
$\mathrm{C}(26)$ & $586(10)$ & $2249(7)$ & $10876(8)$ & $81(3)$ \\
$\mathrm{C}(7)$ & $4677(8)$ & $6020(7)$ & $5682(7)$ & $68(2)$ \\
$\mathrm{C}(11)$ & $720(8)$ & $6063(6)$ & $6249(7)$ & $67(2)$ \\
$\mathrm{C}(20)$ & $-1342(7)$ & $1492(6)$ & $10318(8)$ & $72(3)$ \\
$\mathrm{C}(23)$ & $-2535(8)$ & $4761(7)$ & $8663(7)$ & $65(2)$ \\
$\mathrm{C}(15)$ & $4616(7)$ & $4630(7)$ & $8441(8)$ & $70(3)$ \\
$\mathrm{C}(19)$ & $-2343(7)$ & $1547(6)$ & $10146(8)$ & $72(3)$ \\
$\mathrm{C}(24)$ & $-2426(9)$ & $3541(10)$ & $7609(8)$ & $86(3)$ \\
\hline
\end{tabular}

Table S4. Bond lengths $[\AA]$ and angles $\left[{ }^{\circ}\right]$ for compound $\mathbf{1}$.

\begin{tabular}{ll}
\hline $\mathrm{Pd}(1)-\mathrm{P}(1)$ & $2.2860(17)$ \\
$\mathrm{Pd}(1)-\mathrm{O}(1)$ & $2.108(4)$ \\
$\mathrm{Pd}(1)-\mathrm{C}(46)$ & $1.975(7)$ \\
$\mathrm{Pd}(1)-\mathrm{C}(1)$ & $2.069(6)$ \\
$\mathrm{P}(1)-\mathrm{C}(40)$ & $1.812(7)$ \\
$\mathrm{P}(1)-\mathrm{C}(28)$ & $1.814(7)$ \\
$\mathrm{P}(1)-\mathrm{C}(34)$ & $1.821(6)$ \\
$\mathrm{O}(1)-\mathrm{C}(47)$ & $1.346(8)$ \\
$\mathrm{O}(2)-\mathrm{C}(46)$ & $1.225(8)$ \\
$\mathrm{N}(1)-\mathrm{C}(2)$ & $1.386(9)$ \\
$\mathrm{N}(1)-\mathrm{C}(1)$ & $1.361(8)$ \\
$\mathrm{N}(1)-\mathrm{C}(4)$ & $1.439(9)$ \\
$\mathrm{N}(2)-\mathrm{C}(3)$ & $1.391(8)$ \\
$\mathrm{N}(2)-\mathrm{C}(1)$ & $1.354(9)$ \\
$\mathrm{N}(2)-\mathrm{C}(16)$ & $1.441(9)$ \\
$\mathrm{C}(45)-\mathrm{C}(40)$ & $1.391(10)$ \\
$\mathrm{C}(45)-\mathrm{C}(46)$ & $1.523(9)$ \\
$\mathrm{C}(45)-\mathrm{C}(44)$ & $1.407(10)$ \\
$\mathrm{C}(2)-\mathrm{C}(3)$ & $1.335(10)$ \\
$\mathrm{C}(40)-\mathrm{C}(41)$ & $1.404(9)$ \\
$\mathrm{C}(37)-\mathrm{C}(36)$ & $1.370(11)$ \\
$\mathrm{C}(37)-\mathrm{C}(38)$ & $1.382(11)$ \\
$\mathrm{C}(28)-\mathrm{C}(33)$ & $1.402(9)$ \\
$\mathrm{C}(28)-\mathrm{C}(29)$ & $1.402(10)$ \\
$\mathrm{C}(41)-\mathrm{C}(42)$ & $1.374(10)$ \\
$\mathrm{C}(36)-\mathrm{C}(35)$ & $1.370(10)$ \\
$\mathrm{C}(33)-\mathrm{C}(32)$ & $1.386(11)$ \\
$\mathrm{C}(44)-\mathrm{C}(43)$ & $1.373(10)$ \\
$\mathrm{C}(47)-\mathrm{C}(52)$ & $1.407(11)$ \\
$\mathrm{C}(47)-\mathrm{C}(48)$ & $1.386(10)$ \\
$\mathrm{C}(35)-\mathrm{C}(34)$ & $1.404(10)$ \\
$\mathrm{C}(38)-\mathrm{C}(39)$ & $1.388(9)$ \\
$\mathrm{C}(34)-\mathrm{C}(39)$ & $1.390(9)$ \\
&
\end{tabular}




\begin{tabular}{|c|c|}
\hline C(9)-C(13) & $1.517(11)$ \\
\hline $\mathrm{C}(9)-\mathrm{C}(4)$ & $1.402(10)$ \\
\hline $\mathrm{C}(9)-\mathrm{C}(8)$ & $1.400(12)$ \\
\hline $\mathrm{C}(43)-\mathrm{C}(42)$ & $1.390(11)$ \\
\hline $\mathrm{C}(13)-\mathrm{C}(14)$ & $1.541(10)$ \\
\hline$C(13)-C(15)$ & $1.528(11)$ \\
\hline $\mathrm{C}(4)-\mathrm{C}(5)$ & $1.400(11)$ \\
\hline $\mathrm{C}(16)-\mathrm{C}(17)$ & $1.411(10)$ \\
\hline $\mathrm{C}(16)-\mathrm{C}(21)$ & $1.377(11)$ \\
\hline$C(5)-C(6)$ & $1.387(12)$ \\
\hline $\mathrm{C}(5)-\mathrm{C}(10)$ & $1.542(12)$ \\
\hline $\mathrm{C}(52)-\mathrm{C}(51)$ & $1.388(10)$ \\
\hline $\mathrm{C}(17)-\mathrm{C}(22)$ & $1.517(12)$ \\
\hline $\mathrm{C}(17)-\mathrm{C}(18)$ & $1.394(12)$ \\
\hline $\mathrm{C}(31)-\mathrm{C}(30)$ & $1.388(11)$ \\
\hline $\mathrm{C}(31)-\mathrm{C}(32)$ & $1.383(11)$ \\
\hline $\mathrm{C}(27)-\mathrm{C}(25)$ & $1.528(11)$ \\
\hline C(48)-C(49) & $1.404(10)$ \\
\hline $\mathrm{C}(25)-\mathrm{C}(21)$ & $1.509(11)$ \\
\hline$C(25)-C(26)$ & $1.432(13)$ \\
\hline $\mathrm{C}(30)-\mathrm{C}(29)$ & $1.369(11)$ \\
\hline C(50)-C(49) & $1.414(13)$ \\
\hline $\mathrm{C}(50)-\mathrm{C}(51)$ & $1.351(13)$ \\
\hline $\mathrm{C}(8)-\mathrm{C}(7)$ & $1.354(13)$ \\
\hline $\mathrm{C}(6)-\mathrm{C}(7)$ & $1.388(13)$ \\
\hline $\mathrm{C}(12)-\mathrm{C}(10)$ & $1.510(12)$ \\
\hline $\mathrm{C}(22)-\mathrm{C}(23)$ & $1.533(12)$ \\
\hline $\mathrm{C}(22)-\mathrm{C}(24)$ & $1.531(12)$ \\
\hline $\mathrm{C}(10)-\mathrm{C}(11)$ & $1.534(12)$ \\
\hline C(18)-C(19) & $1.396(14)$ \\
\hline $\mathrm{C}(21)-\mathrm{C}(20)$ & $1.400(11)$ \\
\hline $\mathrm{C}(20)-\mathrm{C}(19)$ & $1.361(14)$ \\
\hline $\mathrm{O}(1)-\mathrm{Pd}(1)-\mathrm{P}(1)$ & $96.02(13)$ \\
\hline $\mathrm{C}(46)-\mathrm{Pd}(1)-\mathrm{P}(1)$ & $84.1(2)$ \\
\hline $\mathrm{C}(46)-\mathrm{Pd}(1)-\mathrm{O}(1)$ & $177.9(2)$ \\
\hline C(46)-Pd(1)-C(1) & $89.5(3)$ \\
\hline $\mathrm{C}(1)-\mathrm{Pd}(1)-\mathrm{P}(1)$ & $170.15(18)$ \\
\hline $\mathrm{C}(1)-\mathrm{Pd}(1)-\mathrm{O}(1)$ & $90.1(2)$ \\
\hline $\mathrm{C}(40)-\mathrm{P}(1)-\mathrm{Pd}(1)$ & $100.9(2)$ \\
\hline $\mathrm{C}(40)-\mathrm{P}(1)-\mathrm{C}(28)$ & $107.4(3)$ \\
\hline $\mathrm{C}(40)-\mathrm{P}(1)-\mathrm{C}(34)$ & $103.3(3)$ \\
\hline $\mathrm{C}(28)-\mathrm{P}(1)-\mathrm{Pd}(1)$ & $117.1(2)$ \\
\hline $\mathrm{C}(28)-\mathrm{P}(1)-\mathrm{C}(34)$ & $102.5(3)$ \\
\hline $\mathrm{C}(34)-\mathrm{P}(1)-\mathrm{Pd}(1)$ & $124.0(2)$ \\
\hline $\mathrm{C}(47)-\mathrm{O}(1)-\mathrm{Pd}(1)$ & $118.7(4)$ \\
\hline $\mathrm{C}(2)-\mathrm{N}(1)-\mathrm{C}(4)$ & $122.0(5)$ \\
\hline $\mathrm{C}(1)-\mathrm{N}(1)-\mathrm{C}(2)$ & $110.6(6)$ \\
\hline C(1)-N(1)-C(4) & $127.5(5)$ \\
\hline $\mathrm{C}(3)-\mathrm{N}(2)-\mathrm{C}(16)$ & $120.5(6)$ \\
\hline $\mathrm{C}(1)-\mathrm{N}(2)-\mathrm{C}(3)$ & $111.1(6)$ \\
\hline $\mathrm{C}(1)-\mathrm{N}(2)-\mathrm{C}(16)$ & $128.4(5)$ \\
\hline$C(40)-C(45)-C(46)$ & $118.1(6)$ \\
\hline $\mathrm{C}(40)-\mathrm{C}(45)-\mathrm{C}(44)$ & $119.8(6)$ \\
\hline$C(44)-C(45)-C(46)$ & $122.1(6)$ \\
\hline $\mathrm{C}(3)-\mathrm{C}(2)-\mathrm{N}(1)$ & $107.4(6)$ \\
\hline
\end{tabular}




\begin{tabular}{|c|c|}
\hline $\mathrm{C}(2)-\mathrm{C}(3)-\mathrm{N}(2)$ & $106.6(6)$ \\
\hline $\mathrm{C}(45)-\mathrm{C}(40)-\mathrm{P}(1)$ & $113.9(5)$ \\
\hline $\mathrm{C}(45)-\mathrm{C}(40)-\mathrm{C}(41)$ & $119.5(6)$ \\
\hline $\mathrm{C}(41)-\mathrm{C}(40)-\mathrm{P}(1)$ & $126.4(5)$ \\
\hline $\mathrm{O}(2)-\mathrm{C}(46)-\mathrm{Pd}(1)$ & $125.0(5)$ \\
\hline $\mathrm{O}(2)-\mathrm{C}(46)-\mathrm{C}(45)$ & $116.6(6)$ \\
\hline $\mathrm{C}(45)-\mathrm{C}(46)-\mathrm{Pd}(1)$ & $118.4(5)$ \\
\hline $\mathrm{C}(36)-\mathrm{C}(37)-\mathrm{C}(38)$ & 119.3(6) \\
\hline $\mathrm{C}(33)-\mathrm{C}(28)-\mathrm{P}(1)$ & $118.9(5)$ \\
\hline $\mathrm{C}(33)-\mathrm{C}(28)-\mathrm{C}(29)$ & $118.2(7)$ \\
\hline C(29)-C(28)-P(1) & $122.8(5)$ \\
\hline$C(42)-C(41)-C(40)$ & $120.2(7)$ \\
\hline $\mathrm{C}(35)-\mathrm{C}(36)-\mathrm{C}(37)$ & $121.0(7)$ \\
\hline $\mathrm{C}(32)-\mathrm{C}(33)-\mathrm{C}(28)$ & $119.9(7)$ \\
\hline$C(43)-C(44)-C(45)$ & $119.5(7)$ \\
\hline $\mathrm{O}(1)-\mathrm{C}(47)-\mathrm{C}(52)$ & $121.3(7)$ \\
\hline $\mathrm{O}(1)-\mathrm{C}(47)-\mathrm{C}(48)$ & $120.4(6)$ \\
\hline $\mathrm{C}(48)-\mathrm{C}(47)-\mathrm{C}(52)$ & $118.3(6)$ \\
\hline $\mathrm{C}(36)-\mathrm{C}(35)-\mathrm{C}(34)$ & $120.3(7)$ \\
\hline $\mathrm{N}(1)-\mathrm{C}(1)-\mathrm{Pd}(1)$ & $127.3(5)$ \\
\hline $\mathrm{N}(2)-\mathrm{C}(1)-\mathrm{Pd}(1)$ & $128.3(5)$ \\
\hline $\mathrm{N}(2)-\mathrm{C}(1)-\mathrm{N}(1)$ & $104.4(5)$ \\
\hline $\mathrm{C}(37)-\mathrm{C}(38)-\mathrm{C}(39)$ & $121.0(7)$ \\
\hline C(35)-C(34)-P(1) & $121.7(5)$ \\
\hline C(39)-C(34)-P(1) & $119.4(5)$ \\
\hline $\mathrm{C}(39)-\mathrm{C}(34)-\mathrm{C}(35)$ & $118.9(6)$ \\
\hline $\mathrm{C}(4)-\mathrm{C}(9)-\mathrm{C}(13)$ & $123.4(7)$ \\
\hline $\mathrm{C}(8)-\mathrm{C}(9)-\mathrm{C}(13)$ & $119.5(7)$ \\
\hline C(8)-C(9)-C(4) & $117.0(8)$ \\
\hline $\mathrm{C}(44)-\mathrm{C}(43)-\mathrm{C}(42)$ & $121.0(7)$ \\
\hline $\mathrm{C}(9)-\mathrm{C}(13)-\mathrm{C}(14)$ & $109.9(6)$ \\
\hline $\mathrm{C}(9)-\mathrm{C}(13)-\mathrm{C}(15)$ & $112.9(7)$ \\
\hline $\mathrm{C}(15)-\mathrm{C}(13)-\mathrm{C}(14)$ & 109.3(6) \\
\hline $\mathrm{C}(41)-\mathrm{C}(42)-\mathrm{C}(43)$ & $120.0(7)$ \\
\hline $\mathrm{C}(9)-\mathrm{C}(4)-\mathrm{N}(1)$ & $117.6(7)$ \\
\hline $\mathrm{C}(5)-\mathrm{C}(4)-\mathrm{N}(1)$ & $119.7(6)$ \\
\hline $\mathrm{C}(5)-\mathrm{C}(4)-\mathrm{C}(9)$ & $122.6(7)$ \\
\hline $\mathrm{C}(17)-\mathrm{C}(16)-\mathrm{N}(2)$ & $116.3(6)$ \\
\hline $\mathrm{C}(21)-\mathrm{C}(16)-\mathrm{N}(2)$ & $119.2(6)$ \\
\hline$C(21)-C(16)-C(17)$ & $124.3(7)$ \\
\hline $\mathrm{C}(38)-\mathrm{C}(39)-\mathrm{C}(34)$ & $119.5(7)$ \\
\hline$C(4)-C(5)-C(10)$ & $120.8(7)$ \\
\hline$C(6)-C(5)-C(4)$ & $117.1(8)$ \\
\hline $\mathrm{C}(6)-\mathrm{C}(5)-\mathrm{C}(10)$ & $122.0(8)$ \\
\hline $\mathrm{C}(51)-\mathrm{C}(52)-\mathrm{C}(47)$ & $119.7(8)$ \\
\hline$C(16)-C(17)-C(22)$ & $122.3(7)$ \\
\hline $\mathrm{C}(18)-\mathrm{C}(17)-\mathrm{C}(16)$ & $116.0(8)$ \\
\hline $\mathrm{C}(18)-\mathrm{C}(17)-\mathrm{C}(22)$ & $121.7(7)$ \\
\hline $\mathrm{C}(32)-\mathrm{C}(31)-\mathrm{C}(30)$ & $119.3(8)$ \\
\hline $\mathrm{C}(47)-\mathrm{C}(48)-\mathrm{C}(49)$ & 121.1(8) \\
\hline $\mathrm{C}(21)-\mathrm{C}(25)-\mathrm{C}(27)$ & $110.4(7)$ \\
\hline$C(26)-C(25)-C(27)$ & $110.4(7)$ \\
\hline$C(26)-C(25)-C(21)$ & $113.6(7)$ \\
\hline$C(29)-C(30)-C(31)$ & $120.3(7)$ \\
\hline $\mathrm{C}(30)-\mathrm{C}(29)-\mathrm{C}(28)$ & $121.2(7)$ \\
\hline $\mathrm{C}(51)-\mathrm{C}(50)-\mathrm{C}(49)$ & $118.6(7)$ \\
\hline
\end{tabular}




$\begin{array}{ll}\mathrm{C}(48)-\mathrm{C}(49)-\mathrm{C}(50) & 119.5(8) \\ \mathrm{C}(7)-\mathrm{C}(8)-\mathrm{C}(9) & 121.6(8) \\ \mathrm{C}(5)-\mathrm{C}(6)-\mathrm{C}(7) & 121.3(8) \\ \mathrm{C}(50)-\mathrm{C}(51)-\mathrm{C}(52) & 122.7(8) \\ \mathrm{C}(17)-\mathrm{C}(22)-\mathrm{C}(23) & 112.4(7) \\ \mathrm{C}(17)-\mathrm{C}(22)-\mathrm{C}(24) & 112.4(8) \\ \mathrm{C}(24)-\mathrm{C}(22)-\mathrm{C}(23) & 109.4(7) \\ \mathrm{C}(12)-\mathrm{C}(10)-\mathrm{C}(5) & 112.4(8) \\ \mathrm{C}(12)-\mathrm{C}(10)-\mathrm{C}(11) & 108.8(7) \\ \mathrm{C}(11)-\mathrm{C}(10)-\mathrm{C}(5) & 111.0(6) \\ \mathrm{C}(17)-\mathrm{C}(18)-\mathrm{C}(19) & 120.5(8) \\ \mathrm{C}(16)-\mathrm{C}(21)-\mathrm{C}(25) & 122.6(7) \\ \mathrm{C}(16)-\mathrm{C}(21)-\mathrm{C}(20) & 117.3(8) \\ \mathrm{C}(20)-\mathrm{C}(21)-\mathrm{C}(25) & 120.1(8) \\ \mathrm{C}(31)-\mathrm{C}(32)-\mathrm{C}(33) & 121.0(7) \\ \mathrm{C}(8)-\mathrm{C}(7)-\mathrm{C}(6) & 120.4(8) \\ \mathrm{C}(19)-\mathrm{C}(20)-\mathrm{C}(21) & 120.4(9) \\ \mathrm{C}(20)-\mathrm{C}(19)-\mathrm{C}(18) & 121.5(8)\end{array}$

Table S5. Anisotropic displacement parameters $\left(\AA^{2} \times 10^{3}\right)$ for compound 1. The anisotropic displacement factor exponent takes the form: $-2 \pi^{2}\left[h^{2} a^{* 2} U^{11}+\ldots+2 h k a^{*} b^{*} U^{12}\right]$

\begin{tabular}{lllllll}
\hline & $\mathrm{U}^{11}$ & $\mathrm{U}^{22}$ & $\mathrm{U}^{33}$ & $\mathrm{U}^{23}$ & $\mathrm{U}^{13}$ & $\mathrm{U}^{12}$ \\
\hline $\mathrm{Pd}(1)$ & $32(1)$ & $24(1)$ & $64(1)$ & $-14(1)$ & $-22(1)$ & $6(1)$ \\
$\mathrm{P}(1)$ & $34(1)$ & $25(1)$ & $64(1)$ & $-14(1)$ & $-21(1)$ & $6(1)$ \\
$\mathrm{O}(1)$ & $36(2)$ & $27(2)$ & $77(3)$ & $-17(2)$ & $-28(2)$ & $7(2)$ \\
$\mathrm{O}(2)$ & $42(3)$ & $40(3)$ & $65(3)$ & $-18(2)$ & $-25(2)$ & $10(2)$ \\
$\mathrm{N}(1)$ & $35(3)$ & $25(3)$ & $70(4)$ & $-16(2)$ & $-26(3)$ & $9(2)$ \\
$\mathrm{N}(2)$ & $31(3)$ & $38(3)$ & $66(4)$ & $-15(3)$ & $-29(3)$ & $9(2)$ \\
$\mathrm{C}(45)$ & $34(3)$ & $29(3)$ & $65(4)$ & $-12(3)$ & $-24(3)$ & $8(3)$ \\
$\mathrm{C}(2)$ & $40(4)$ & $32(3)$ & $74(5)$ & $-24(3)$ & $-32(3)$ & $8(3)$ \\
$\mathrm{C}(3)$ & $35(3)$ & $41(4)$ & $72(5)$ & $-30(3)$ & $-24(3)$ & $9(3)$ \\
$\mathrm{C}(40)$ & $34(3)$ & $24(3)$ & $62(4)$ & $-14(3)$ & $-17(3)$ & $11(2)$ \\
$\mathrm{C}(46)$ & $35(3)$ & $28(3)$ & $64(4)$ & $-13(3)$ & $-19(3)$ & $11(3)$ \\
$\mathrm{C}(37)$ & $54(4)$ & $25(3)$ & $66(5)$ & $-10(3)$ & $-16(4)$ & $6(3)$ \\
$\mathrm{C}(28)$ & $40(4)$ & $30(3)$ & $60(4)$ & $-8(3)$ & $-22(3)$ & $0(3)$ \\
$\mathrm{C}(41)$ & $35(4)$ & $39(4)$ & $69(5)$ & $-22(3)$ & $-18(3)$ & $7(3)$ \\
$\mathrm{C}(36)$ & $48(4)$ & $30(3)$ & $84(6)$ & $-4(3)$ & $-25(4)$ & $7(3)$ \\
$\mathrm{C}(33)$ & $42(4)$ & $34(3)$ & $68(5)$ & $-14(3)$ & $-22(3)$ & $7(3)$ \\
$\mathrm{C}(44)$ & $41(4)$ & $43(4)$ & $65(5)$ & $-16(3)$ & $-19(3)$ & $7(3)$ \\
$\mathrm{C}(47)$ & $33(3)$ & $32(3)$ & $66(4)$ & $-16(3)$ & $-21(3)$ & $7(3)$ \\
$\mathrm{C}(35)$ & $50(4)$ & $39(4)$ & $68(5)$ & $-6(3)$ & $-27(4)$ & $0(3)$ \\
$\mathrm{C}(1)$ & $33(3)$ & $36(3)$ & $56(4)$ & $-13(3)$ & $-25(3)$ & $3(3)$ \\
$\mathrm{C}(38)$ & $49(4)$ & $30(3)$ & $73(5)$ & $-16(3)$ & $-23(4)$ & $-1(3)$ \\
$\mathrm{C}(34)$ & $37(3)$ & $26(3)$ & $58(4)$ & $-9(3)$ & $-19(3)$ & $2(3)$ \\
$\mathrm{C}(9)$ & $44(4)$ & $26(3)$ & $80(5)$ & $-21(3)$ & $-21(4)$ & $8(3)$ \\
$\mathrm{C}(43)$ & $37(4)$ & $38(4)$ & $73(5)$ & $-16(3)$ & $-24(3)$ & $7(3)$ \\
$\mathrm{C}(13)$ & $47(4)$ & $32(3)$ & $87(6)$ & $-15(3)$ & $-36(4)$ & $3(3)$ \\
$\mathrm{C}(42)$ & $34(4)$ & $41(4)$ & $74(5)$ & $-19(3)$ & $-20(3)$ & $13(3)$ \\
$\mathrm{C}(4)$ & $47(4)$ & $20(3)$ & $69(5)$ & $-13(3)$ & $-24(3)$ & $3(3)$ \\
$\mathrm{C}(16)$ & $33(3)$ & $35(3)$ & $59(4)$ & $-19(3)$ & $-16(3)$ & $7(3)$ \\
$\mathrm{C}(39)$ & $42(4)$ & $27(3)$ & $74(5)$ & $-16(3)$ & $-24(3)$ & $7(3)$ \\
$\mathrm{C}(5)$ & $68(5)$ & $24(3)$ & $79(5)$ & $-20(3)$ & $-34(4)$ & $8(3)$ \\
& & & & & &
\end{tabular}




\begin{tabular}{lllllll}
$\mathrm{C}(52)$ & $46(4)$ & $36(4)$ & $78(5)$ & $-15(3)$ & $-27(4)$ & $7(3)$ \\
$\mathrm{C}(17)$ & $41(4)$ & $51(4)$ & $73(5)$ & $-28(4)$ & $-25(4)$ & $8(3)$ \\
$\mathrm{C}(31)$ & $47(4)$ & $44(4)$ & $69(5)$ & $-13(4)$ & $-23(4)$ & $-6(3)$ \\
$\mathrm{C}(14)$ & $59(5)$ & $45(4)$ & $76(5)$ & $-15(4)$ & $-33(4)$ & $2(4)$ \\
$\mathrm{C}(27)$ & $51(5)$ & $50(5)$ & $97(7)$ & $-12(4)$ & $-21(5)$ & $16(4)$ \\
$\mathrm{C}(48)$ & $37(4)$ & $39(4)$ & $78(5)$ & $-18(3)$ & $-29(4)$ & $6(3)$ \\
$\mathrm{C}(25)$ & $37(4)$ & $48(4)$ & $72(5)$ & $-9(4)$ & $-25(3)$ & $10(3)$ \\
$\mathrm{C}(30)$ & $48(4)$ & $45(4)$ & $69(5)$ & $-21(4)$ & $-21(4)$ & $7(3)$ \\
$\mathrm{C}(29)$ & $47(4)$ & $34(3)$ & $74(5)$ & $-19(3)$ & $-26(4)$ & $8(3)$ \\
$\mathrm{C}(50)$ & $43(4)$ & $42(4)$ & $116(7)$ & $-25(5)$ & $-39(5)$ & $6(3)$ \\
$\mathrm{C}(49)$ & $42(4)$ & $52(4)$ & $93(6)$ & $-33(4)$ & $-37(4)$ & $18(3)$ \\
$\mathrm{C}(8)$ & $51(5)$ & $40(4)$ & $98(7)$ & $-25(4)$ & $-23(4)$ & $0(3)$ \\
$\mathrm{C}(6)$ & $83(6)$ & $35(4)$ & $57(5)$ & $-6(3)$ & $-12(4)$ & $-2(4)$ \\
$\mathrm{C}(51)$ & $41(4)$ & $37(4)$ & $89(6)$ & $-14(4)$ & $-20(4)$ & $-2(3)$ \\
$\mathrm{C}(12)$ & $108(8)$ & $39(4)$ & $77(6)$ & $-6(4)$ & $-50(6)$ & $-6(4)$ \\
$\mathrm{C}(22)$ & $38(4)$ & $83(6)$ & $75(5)$ & $-26(5)$ & $-30(4)$ & $14(4)$ \\
$\mathrm{C}(10)$ & $81(6)$ & $30(4)$ & $73(5)$ & $-10(3)$ & $-41(5)$ & $2(4)$ \\
$\mathrm{C}(18)$ & $38(4)$ & $57(5)$ & $114(7)$ & $-38(5)$ & $-26(4)$ & $-1(4)$ \\
$\mathrm{C}(21)$ & $44(4)$ & $35(4)$ & $86(6)$ & $-14(4)$ & $-18(4)$ & $4(3)$ \\
$\mathrm{C}(32)$ & $51(4)$ & $39(4)$ & $75(5)$ & $-8(4)$ & $-26(4)$ & $3(3)$ \\
$\mathrm{C}(26)$ & $96(8)$ & $60(6)$ & $103(8)$ & $1(5)$ & $-67(6)$ & $17(5)$ \\
$\mathrm{C}(7)$ & $65(6)$ & $49(5)$ & $83(7)$ & $-19(4)$ & $-14(5)$ & $-9(4)$ \\
$\mathrm{C}(11)$ & $80(6)$ & $48(5)$ & $97(7)$ & $-21(4)$ & $-58(5)$ & $14(4)$ \\
$\mathrm{C}(20)$ & $51(5)$ & $36(4)$ & $109(7)$ & $-5(4)$ & $-10(5)$ & $3(3)$ \\
$\mathrm{C}(23)$ & $62(5)$ & $61(5)$ & $91(6)$ & $-18(4)$ & $-48(5)$ & $11(4)$ \\
$\mathrm{C}(15)$ & $52(5)$ & $52(5)$ & $125(8)$ & $-26(5)$ & $-50(5)$ & $5(4)$ \\
$\mathrm{C}(19)$ & $41(5)$ & $43(4)$ & $117(8)$ & $-16(5)$ & $-10(5)$ & $-4(4)$ \\
$\mathrm{C}(24)$ & $62(6)$ & $125(9)$ & $105(8)$ & $-70(7)$ & $-53(6)$ & $41(6)$ \\
& & & & & & \\
\hline
\end{tabular}




\section{Computational data}

All stationary points were fully optimized and characterized using harmonic vibrational frequency calculations with M06 functional ${ }^{21}$ including dispersion ${ }^{22}$ in combination with def2SVP basis set ${ }^{23}$ including solvation by tetrahydrofuran (THF) with the continuum SMD model. ${ }^{24}$ Frequency calculations were also used to determine the thermochemistry corrections. Single-point calculations were performed at the DFT(M06)/SMD(THF)/def2TZVP level on the DFT(M06)/SMD(MTHF)/def2SVP-optimized geometries with the aim of refining the potential energies. The geometry optimizations, frequencies and single-point calculations, calculated within the DFT framework, were performed with the Gaussian 09 software package. ${ }^{25}$

\section{Additional information about oxidative addition pathways}

As noted in the main text, one additional transition state was found for the oxidative addition of phenyl benzoate involving cleavage of the $\mathrm{O}-\mathrm{C}($ aryl $)$ bond. This transition state, denoted $\mathbf{T S}_{\mathbf{P h}}\left(\mathbf{O}_{-}\right.$ $\mathbf{C A r}_{\mathrm{Ar}}$-2, features a 3-membered metallacycle (see Figure S2), as opposed to $\mathbf{T S P h}\left(\mathbf{O}-\mathbf{C}_{\mathrm{Ar}}\right)$, which features a 5-membered metallacycle (see Figure 10), and is higher in energy. Similarly, an additional transition state, featuring a 3-membered metallacycle was found for the oxidative addition of benzyl benzoate involving cleavage of the $\mathrm{O}-\mathrm{C}_{\mathrm{Bz}}$ bond. This transition state, denoted $\operatorname{TS}_{\mathbf{P h}}\left(\mathbf{O}-\mathbf{C}_{\mathbf{B z}}\right)$-2, is higher in energy than oxidative addition via a 5-membered metallacycle, $\mathbf{T S}_{\mathbf{P h}}\left(\mathbf{O}-\mathbf{C}_{\mathbf{B z}}\right)$ (see Figure 11). Also included in the energy profiles shown in Figure S2 are the intermediates $\mathbf{R}_{\mathbf{P h}}\left(\mathbf{O}-\mathbf{C}_{\mathbf{A r}}\right)-\mathbf{2}$ and $\mathbf{R}_{\mathbf{B z}}\left(\mathbf{O}-\mathbf{C}_{\mathbf{B z}}\right)$-2, which correspond to pre-reaction complexes. These complexes relate to the initial binding of the substrate to $\operatorname{Pd}(0)$ prior to oxidative addition. Although in the case of oxidative addition of benzyl benzoate to $\operatorname{Pd}(0)$, this complex is significantly lower in energy than the starting materials, this is likely a computational artifact, where the strength of the binding to the phenyl-ring to $\operatorname{Pd}(0)$ is over-estimated. In any case, apart from raising the overall barriers for oxidative addition of benzyl benzoate, this will have no significant impact on the results described and the $\mathrm{S}_{\mathrm{N}} 2$ pathway is still preferred and low in energy.

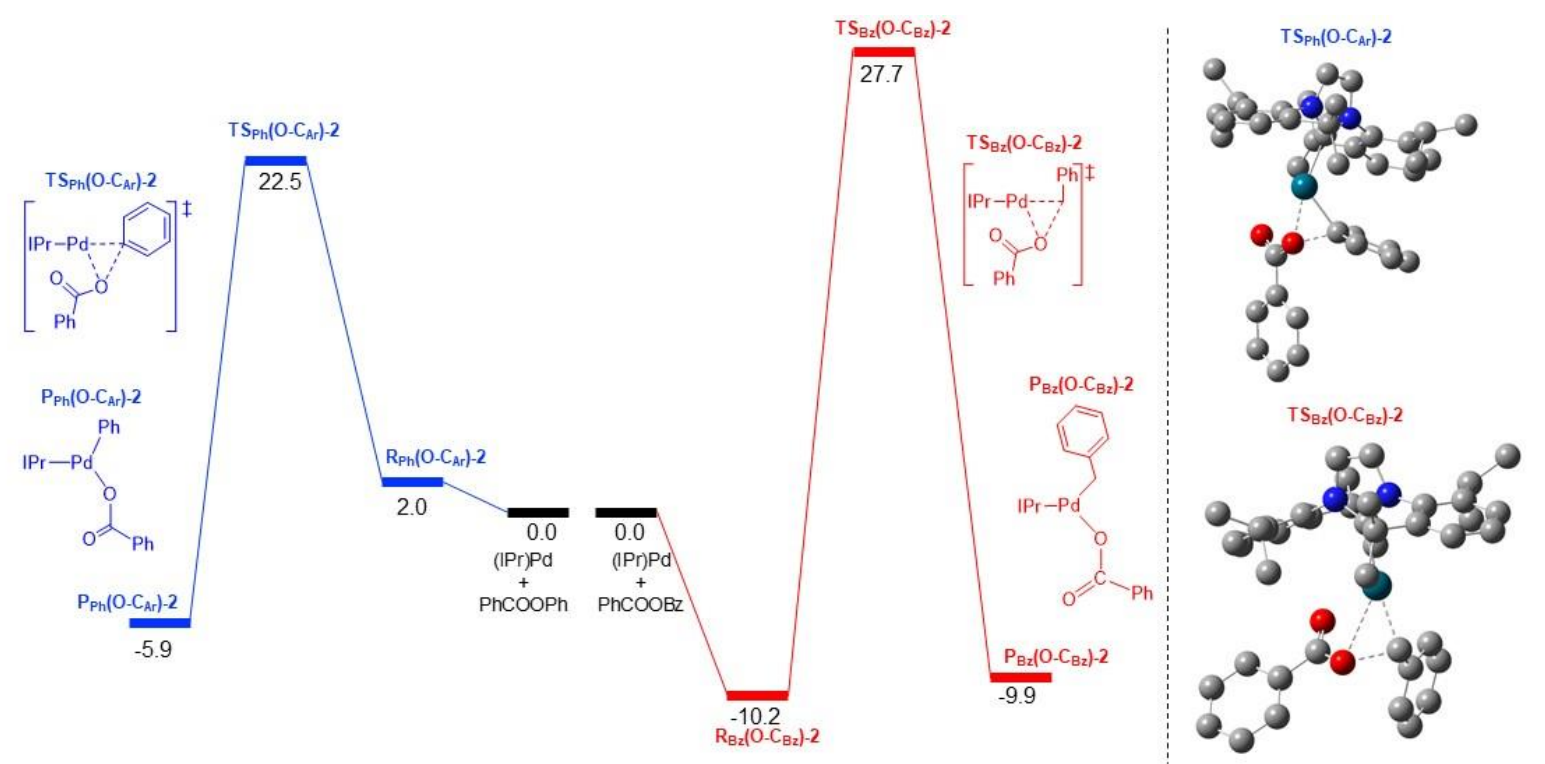

Figure S2. DFT-optimized energy profiles and geometries for the additional oxidative addition transition states corresponding to $\mathrm{O}-\mathrm{C}_{\mathrm{Ar}}$ bond cleavage via a 3-membered metallacycle. 
Relative energies of isomers of the benzyl benzoate oxidative addition product $\left(\mathrm{P}_{\mathrm{Bz}}\left(\mathrm{O}-\mathrm{C}_{\mathrm{Bz}}\right)\right)$

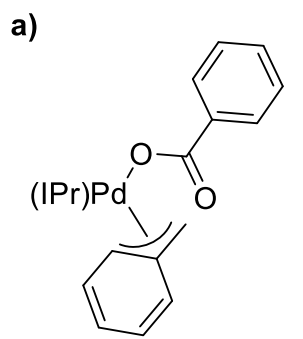

$5.9 \mathrm{kcal} / \mathrm{mol}$ b)

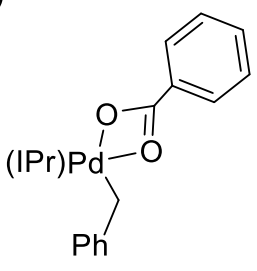

$0.0 \mathrm{kcal} / \mathrm{mol}$ c)

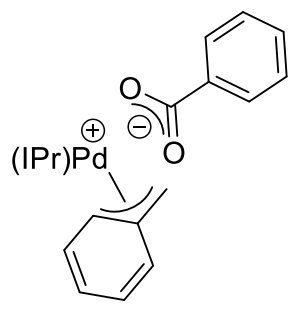

$17.2 \mathrm{kcal} / \mathrm{mol}$

Figure S3. DFT-optimized energies of the isomers of the benzyl benzoate oxidative addition product. a) $\eta^{3}-\mathrm{Bz}$; b) $\kappa^{1}-\mathrm{Bz}, \kappa^{2}-\mathrm{OBz}$; and $\mathbf{c}$ ) ion pair. Relative energies with respect to the lowest energy $\kappa^{1}-\mathrm{Bz}, \kappa^{2}-\mathrm{OBz}$ product.

Relative energies of isomers of the benzyl 2,3,4,5,6-pentafluorobenzoate oxidative addition product ( $\left.\mathbf{P}_{\mathrm{FBz}}\left(\mathbf{O}-\mathrm{C}_{\mathrm{Bz}}\right)\right)$

a)

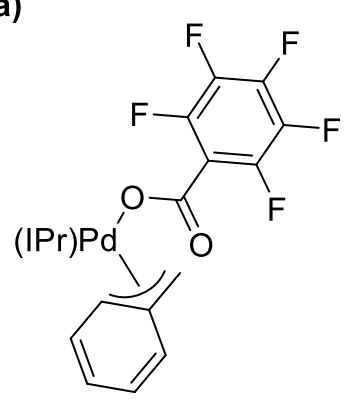

$3.4 \mathrm{kcal} / \mathrm{mol}$ b)<smiles></smiles>

$0.0 \mathrm{kcal} / \mathrm{mol}$ c)<smiles></smiles>

$1.0 \mathrm{kcal} / \mathrm{mol}$ d)<smiles>C=c1ccccc1=Cc1ccccc1</smiles>

$10.8 \mathrm{kcal} / \mathrm{mol}$

Figure S4. DFT-optimized energies of the isomers of the benzyl 2,3,4,5,6-pentafluorobenzoate oxidative addition product. a) $\eta^{3}-\mathrm{Bz}$; b) $\kappa^{1}-\mathrm{Bz}, \kappa^{1}-\mathrm{OBz}$; c) $\kappa^{1}-\mathrm{Bz}, \kappa^{2}-\mathrm{OBz}$; and d) ion pair. Relative energies with respect to the lowest energy $\kappa^{1}-\mathrm{Bz}, \kappa^{1}-\mathrm{OBz}$ product. 
XI(A). NMR spectra of starting materials.
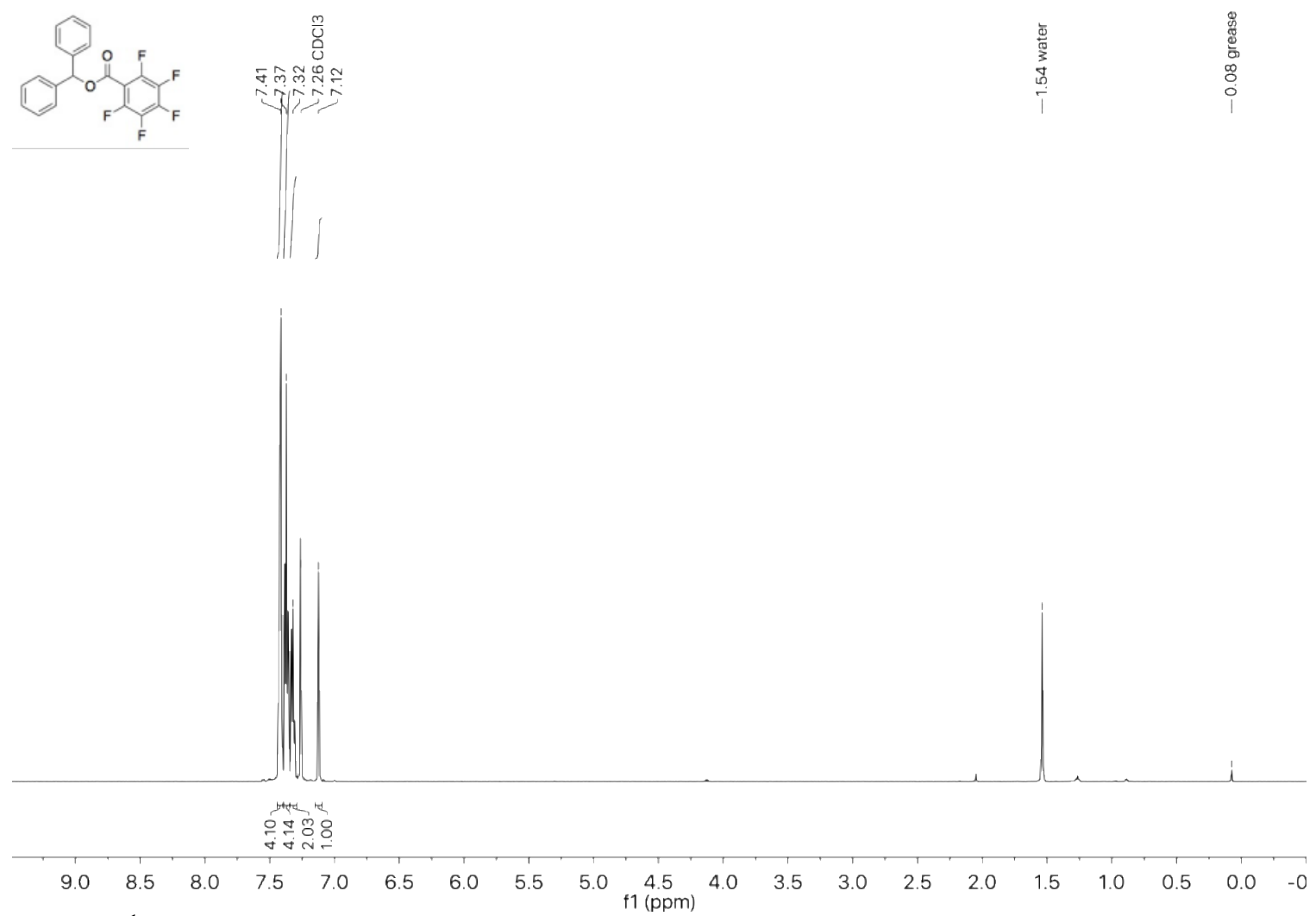

Figure S5: ${ }^{1} \mathrm{H} \mathrm{NMR}\left(\mathrm{CDCl}_{3}, 600 \mathrm{MHz}\right)$ of (Diphenyl)methyl pentafluorobenzoate
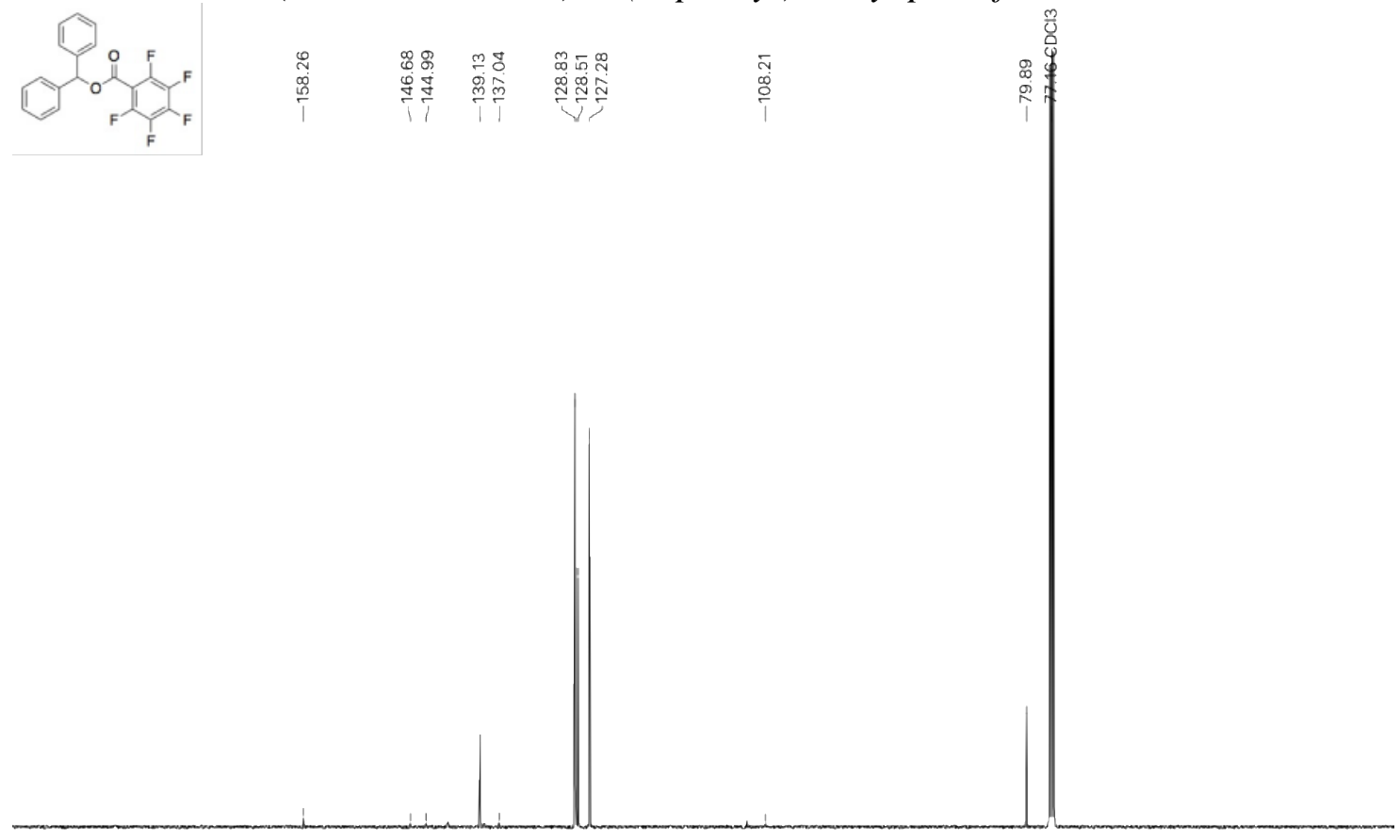

$\begin{array}{lllllllllllllllllllllllllllllllllll}185 & 180 & 175 & 170 & 165 & 160 & 155 & 150 & 145 & 140 & 135 & 130 & 125 & 120 & 115 & 110 & 105 & 100 & 95 & 90 & 85 & 80 & 75 & 70 & 65 & 60 & 55 & 50 & 45 & 4\end{array}$ Figure S6: ${ }^{13} \mathrm{C}\left\{{ }^{1} \mathrm{H}\right\}$ NMR $\left(\mathrm{CDCl}_{3}, 151 \mathrm{MHz}\right)$ of (Diphenyl)methyl pentafluorobenzoate 


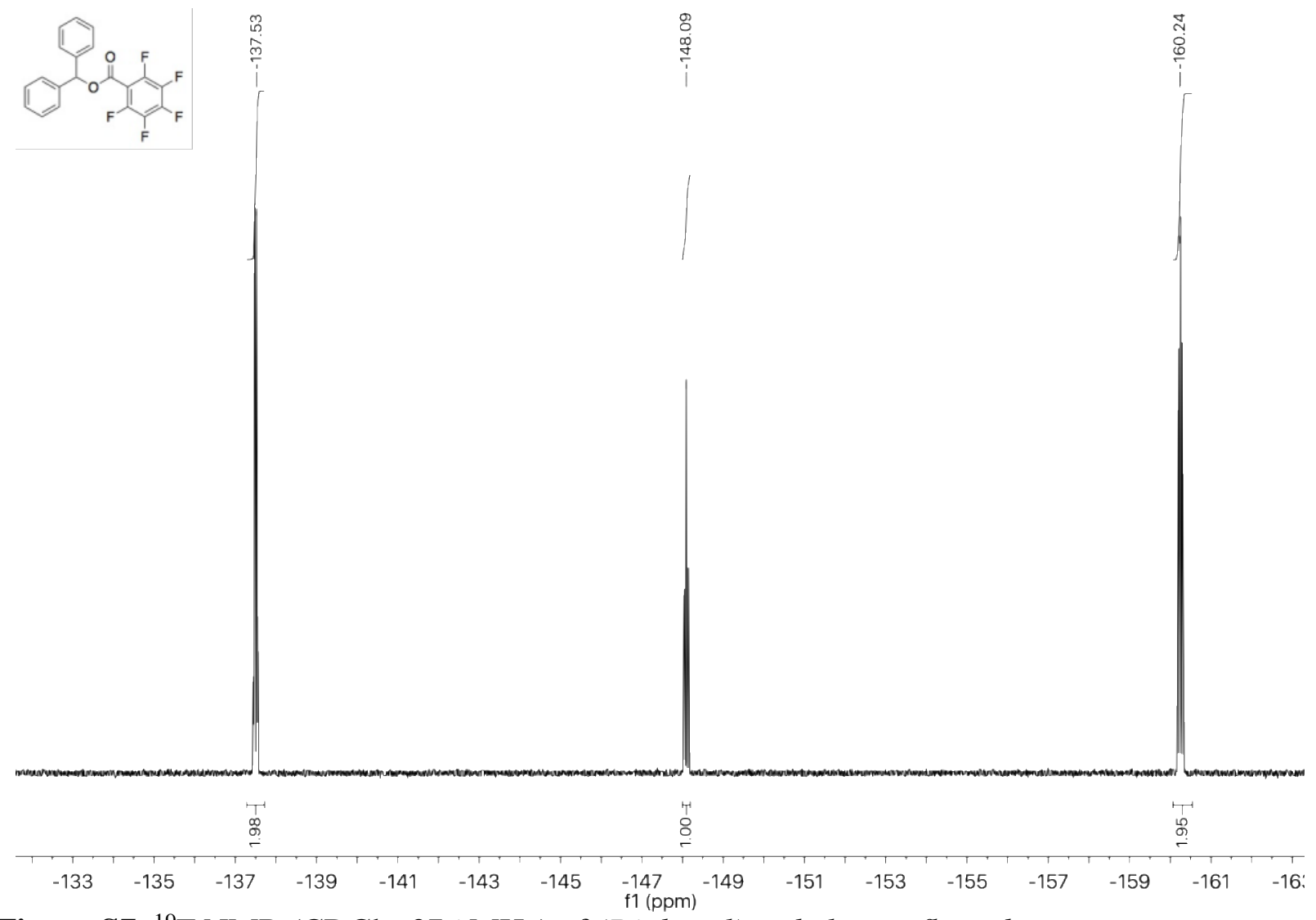

Figure S7: ${ }^{19} \mathrm{~F} \mathrm{NMR}\left(\mathrm{CDCl}_{3}, 376 \mathrm{MHz}\right)$ of (Diphenyl)methyl pentafluorobenzoate 


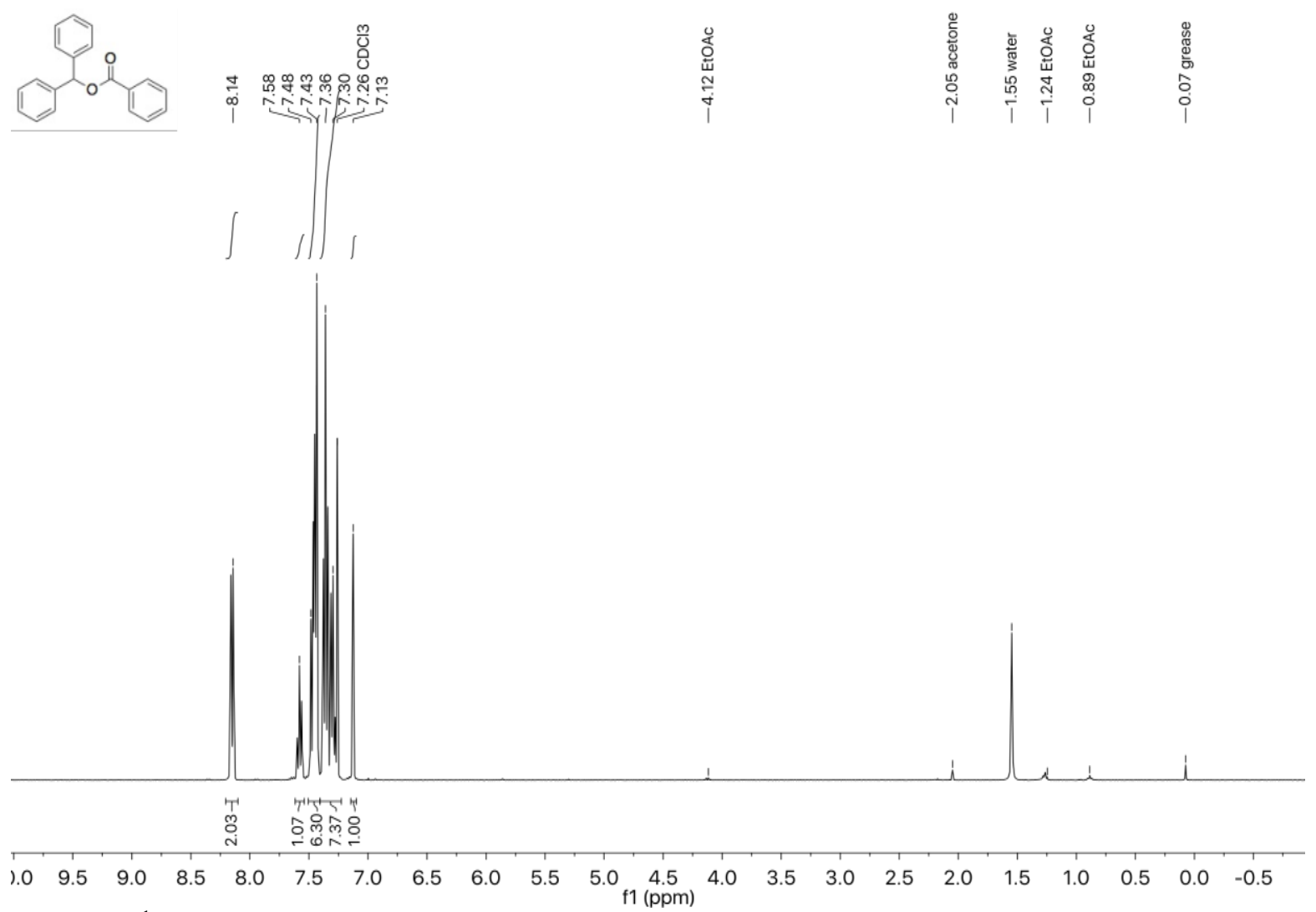

Figure S8: ${ }^{1} \mathrm{H} \mathrm{NMR}\left(\mathrm{CDCl}_{3}, 400 \mathrm{MHz}\right)$ of (Diphenyl)methyl benzoate
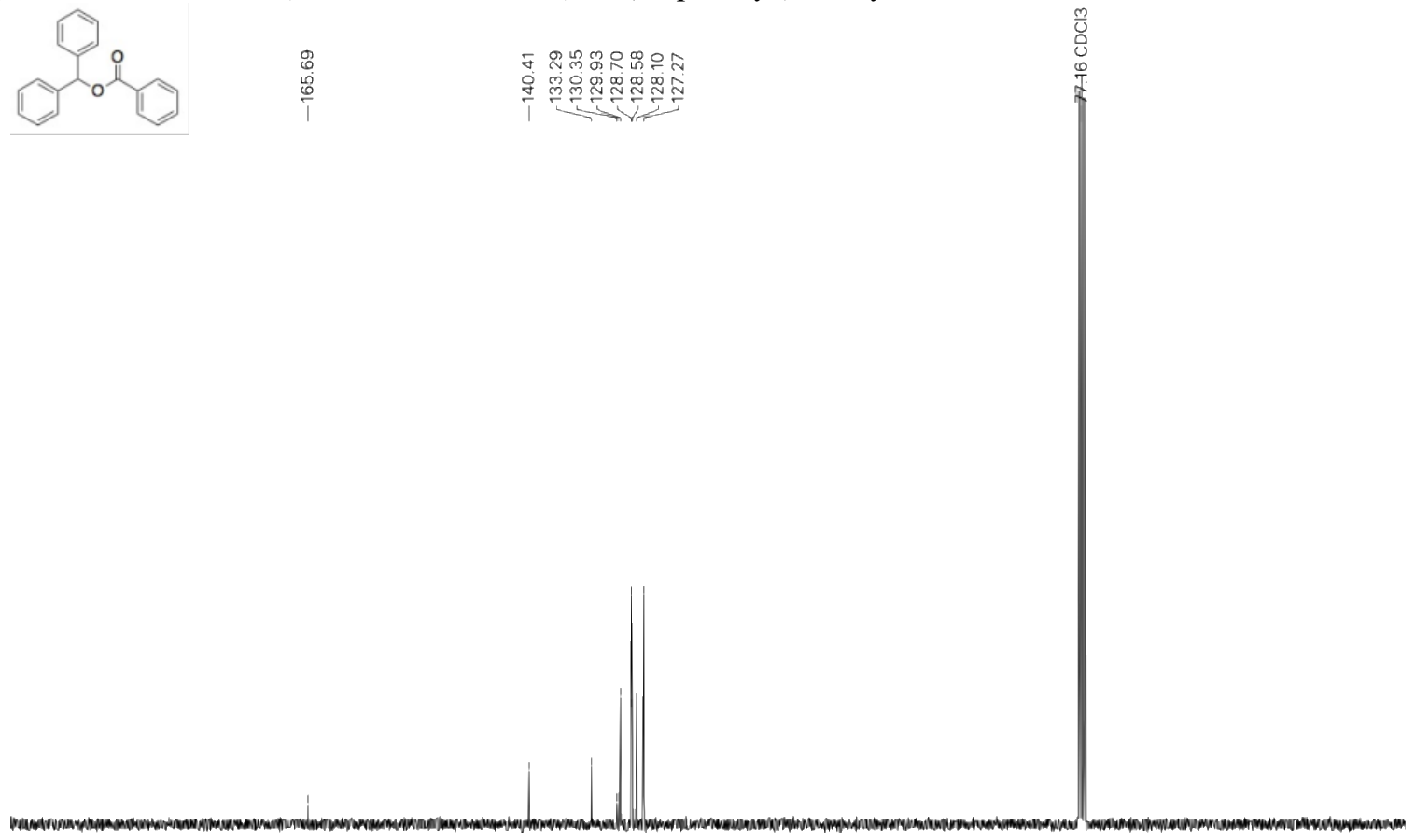

$\begin{array}{llllll}190 & 180 & 170 & 160 & 150 & 140\end{array}$

Figure S9: ${ }^{13} \mathrm{C}\left\{{ }^{1} \mathrm{H}\right\} \mathrm{NMR}\left(\mathrm{CDCl}_{3}, 101 \mathrm{MHz}\right)$ of (Diphenyl)methyl benzoate 


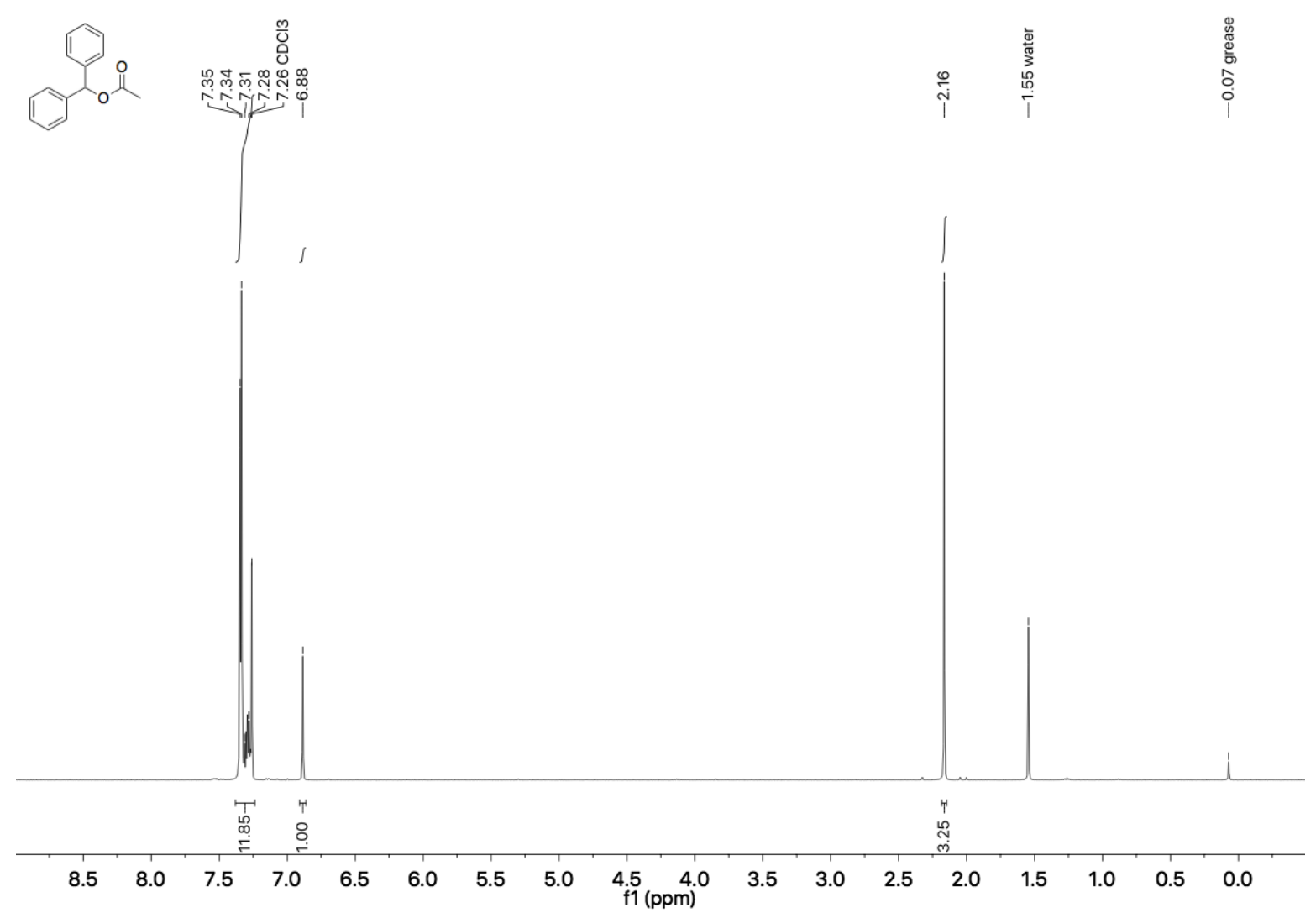

Figure S10: ${ }^{1} \mathrm{H} \mathrm{NMR}\left(\mathrm{CDCl}_{3}, 400 \mathrm{MHz}\right)$ of (Diphenyl)methyl acetate
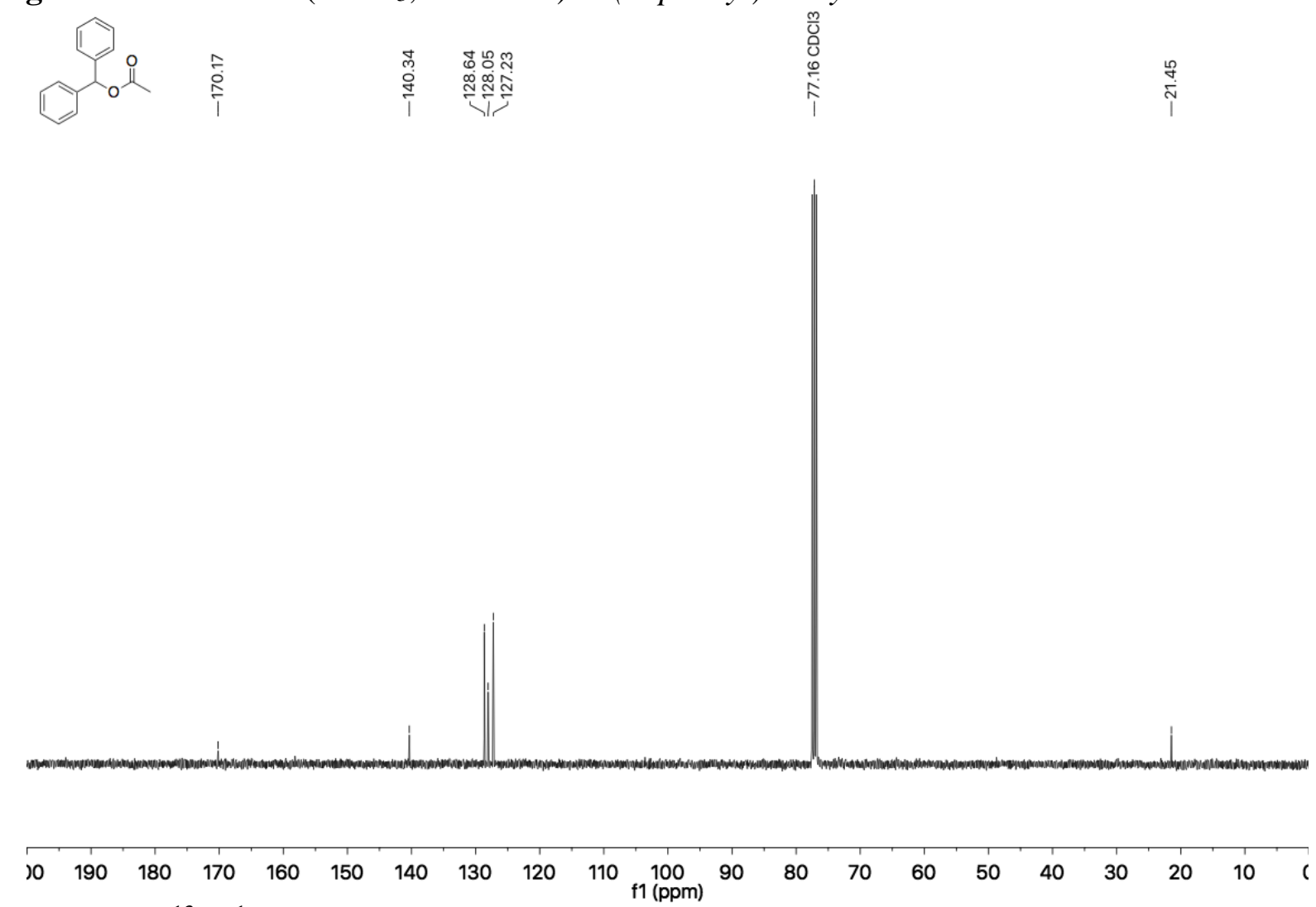

Figure S11: ${ }^{13} \mathrm{C}\left\{{ }^{1} \mathrm{H}\right\} \mathrm{NMR}\left(\mathrm{CDCl}_{3}, 101 \mathrm{MHz}\right)$ of (Diphenyl)methyl acetate 

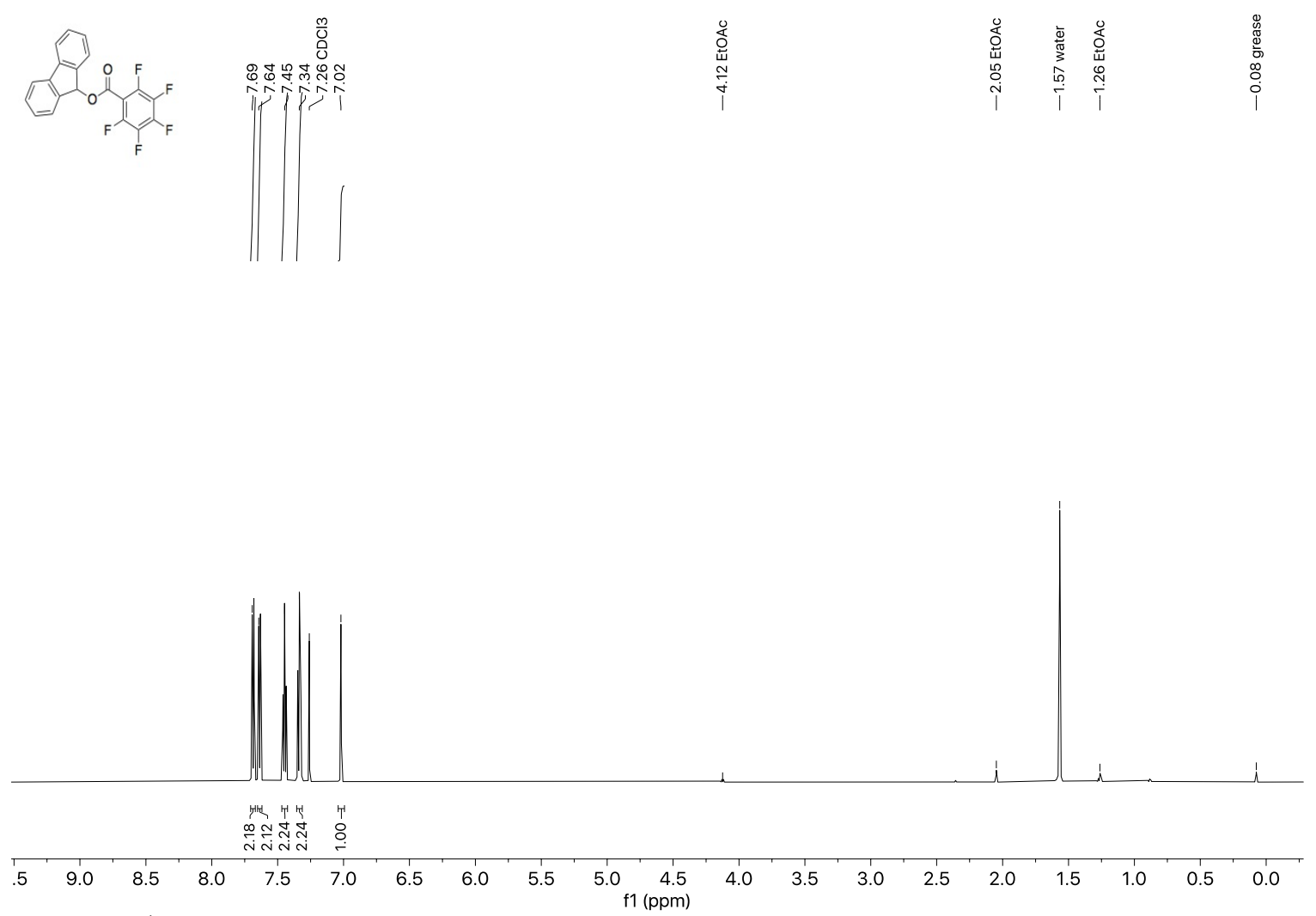

Figure S12: ${ }^{1} \mathrm{H} \mathrm{NMR}\left(\mathrm{CDCl}_{3}, 600 \mathrm{MHz}\right)$ of $9 \mathrm{H}$-fluorene-9-pentafluorobenzoate
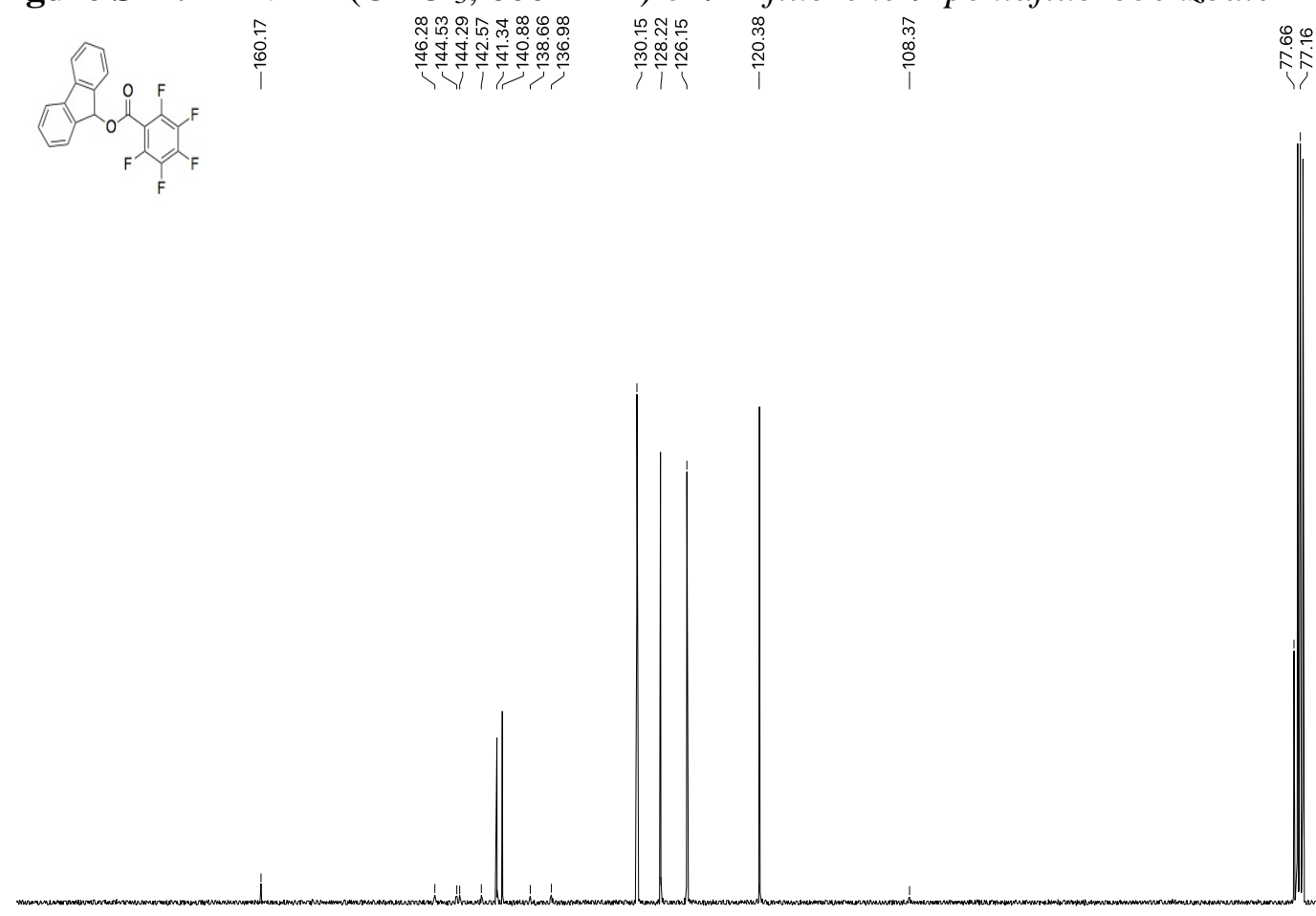

$\begin{array}{llllllllllllllllllllllll}175 & 170 & 165 & 160 & 155 & 150 & 145 & 140 & 135 & 130 & 125 & 120 & 115 & 110 & 105 & 100 & 95 & 90 & 85 & 80 & 75 & 70 & 65 & 6\end{array}$

Figure S13: ${ }^{13} \mathrm{C}\left\{{ }^{1} \mathrm{H}\right\}$ NMR $\left(\mathrm{CDCl}_{3}, 151 \mathrm{MHz}\right)$ of $9 H$-fluorene-9-pentafluorobenzoate 

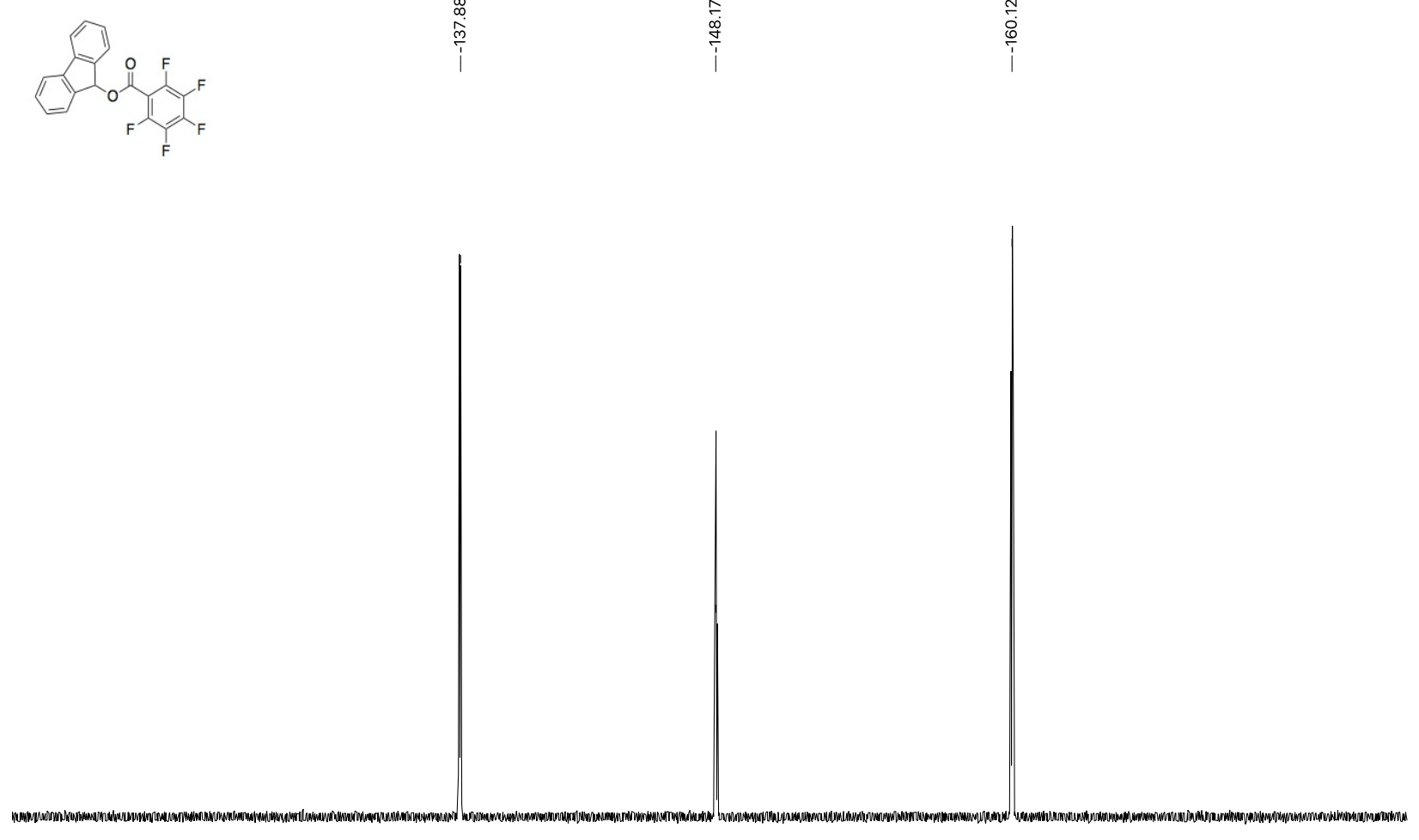

$20-122-124-126-128-130-132-134-136-138-140-142-144-146-148-150-152-154-156-158-160-162-164-166-168-170-172-174-1$; Figure S14: ${ }^{19} \mathrm{~F} \mathrm{NMR}\left(\mathrm{CDCl}_{3}, 376 \mathrm{MHz}\right)$ of 9H-fluorene-9-pentafluorobenzoate 


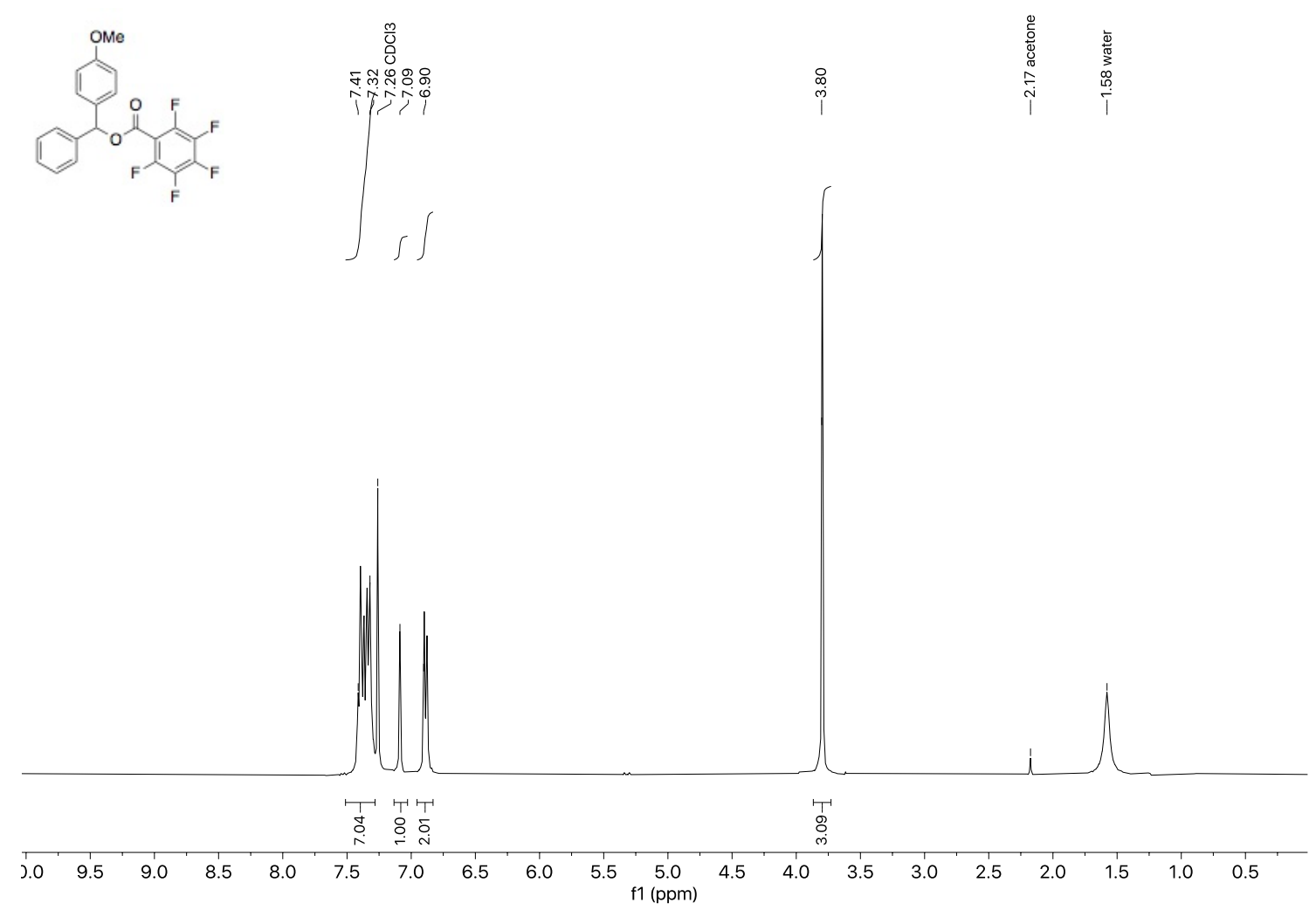

Figure S15: ${ }^{1} \mathrm{H} \quad \mathrm{NMR} \quad\left(\mathrm{CDCl}_{3}, 400 \mathrm{MHz}\right)$ of (4-methoxyphenyl)(phenyl)methyl pentafluorobenzoate 


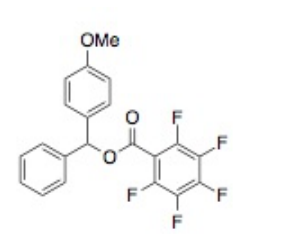

i

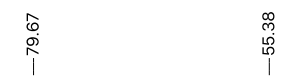

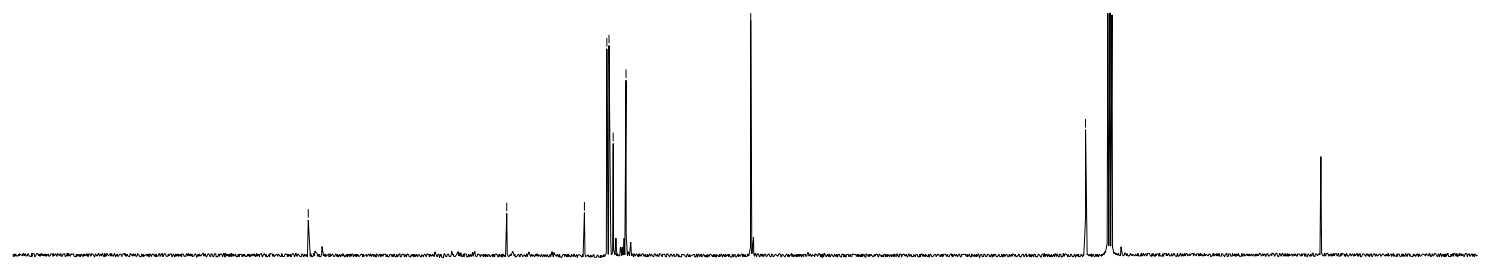

$\begin{array}{llllllllllllllllllllllllllllllllllllll}50 & 185 & 180 & 175 & 170 & 165 & 160 & 155 & 150 & 145 & 140 & 135 & 130 & 125 & 120 & 115 & 110 & 105 & 100 & 95 & 90 & 85 & 80 & 75 & 70 & 65 & 60 & 55 & 50 & 45 & 46\end{array}$

Figure S16: ${ }^{13} \mathrm{C}\left\{{ }^{1} \mathrm{H}\right\} \quad \mathrm{NMR} \quad\left(\mathrm{CDCl}_{3}, 151 \mathrm{MHz}\right)$ of (4-methoxyphenyl)(phenyl)methyl pentafluorobenzoate 

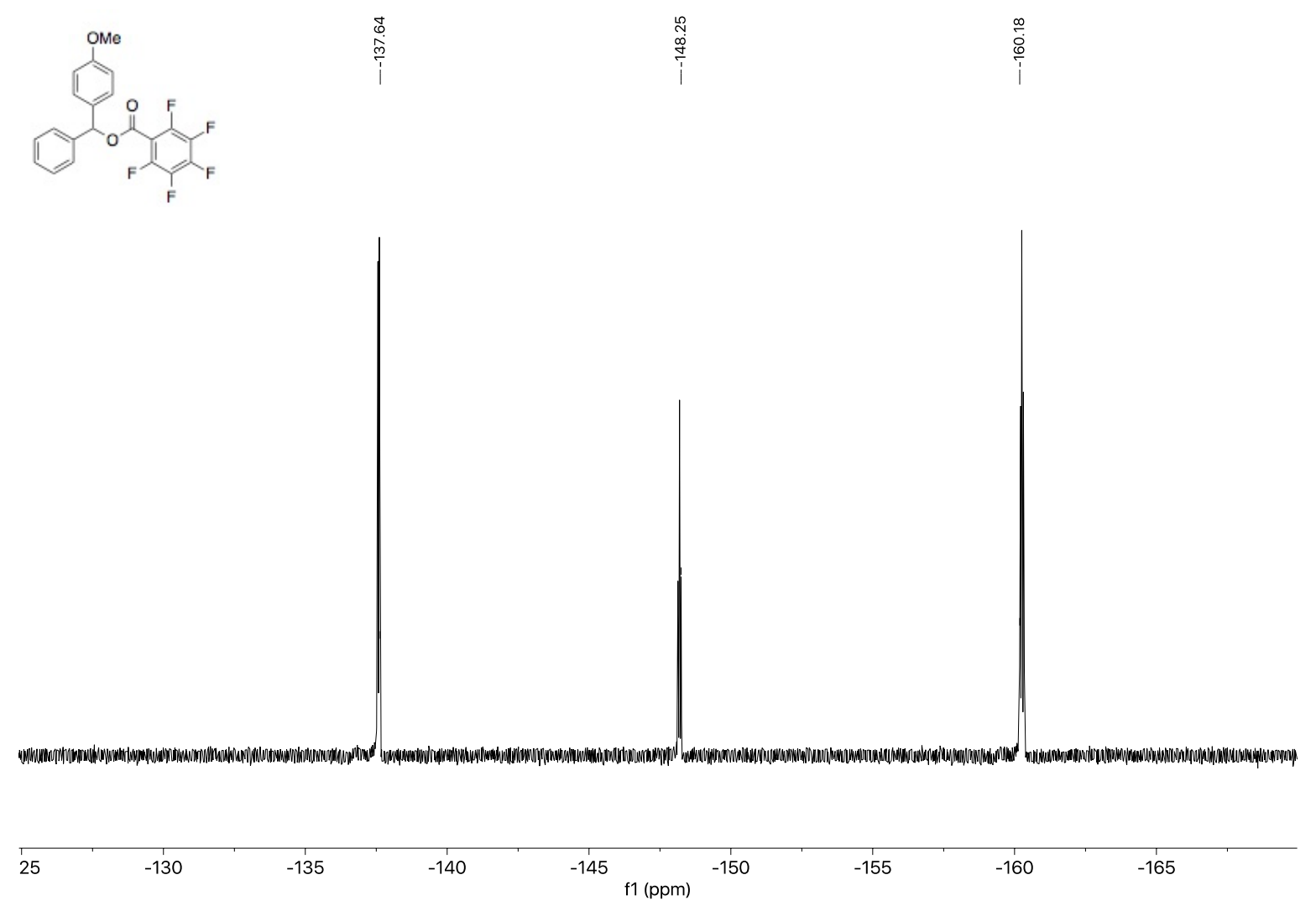

Figure S17: ${ }^{19} \mathrm{~F} \quad \mathrm{NMR} \quad\left(\mathrm{CDCl}_{3}, 376 \mathrm{MHz}\right)$ of (4-methoxyphenyl)(phenyl)methyl pentafluorobenzoate 

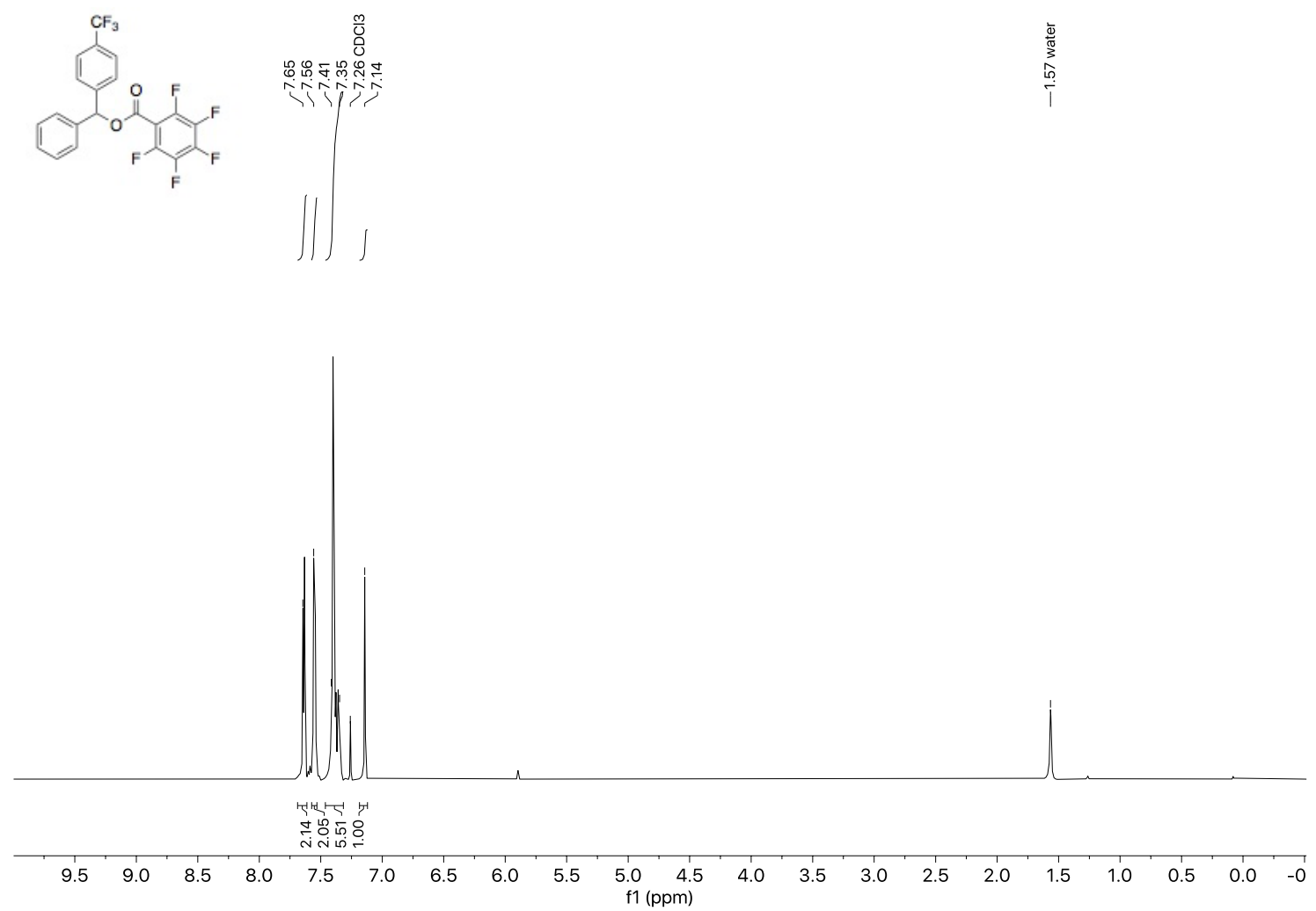

Figure S18: ${ }^{1} \mathrm{H} \quad \mathrm{NMR} \quad\left(\mathrm{CDCl}_{3}, 600 \mathrm{MHz}\right)$ of (4-trifluoromethylphenyl)(phenyl)methyl pentafluorobenzoate 


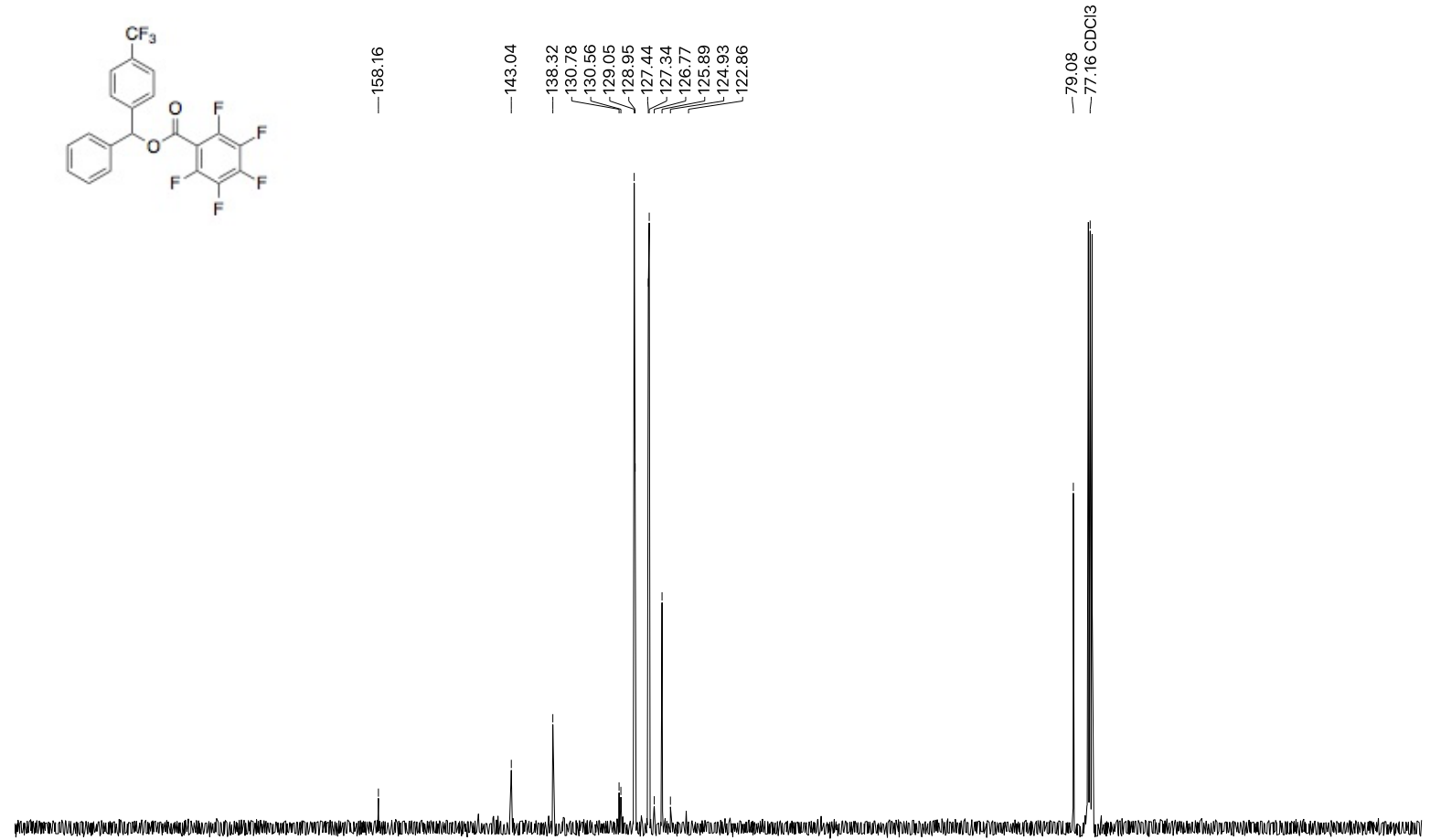

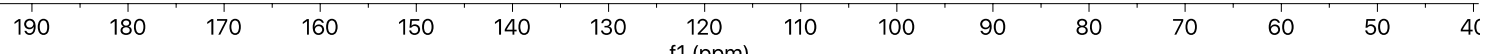

Figure S19: ${ }^{13} \mathrm{C}\left\{{ }^{1} \mathrm{H}\right\} \mathrm{NMR}\left(\mathrm{CDCl}_{3}, 151 \mathrm{MHz}\right)$ of (4-trifluoromethylphenyl)(phenyl)methyl pentafluorobenzoate 


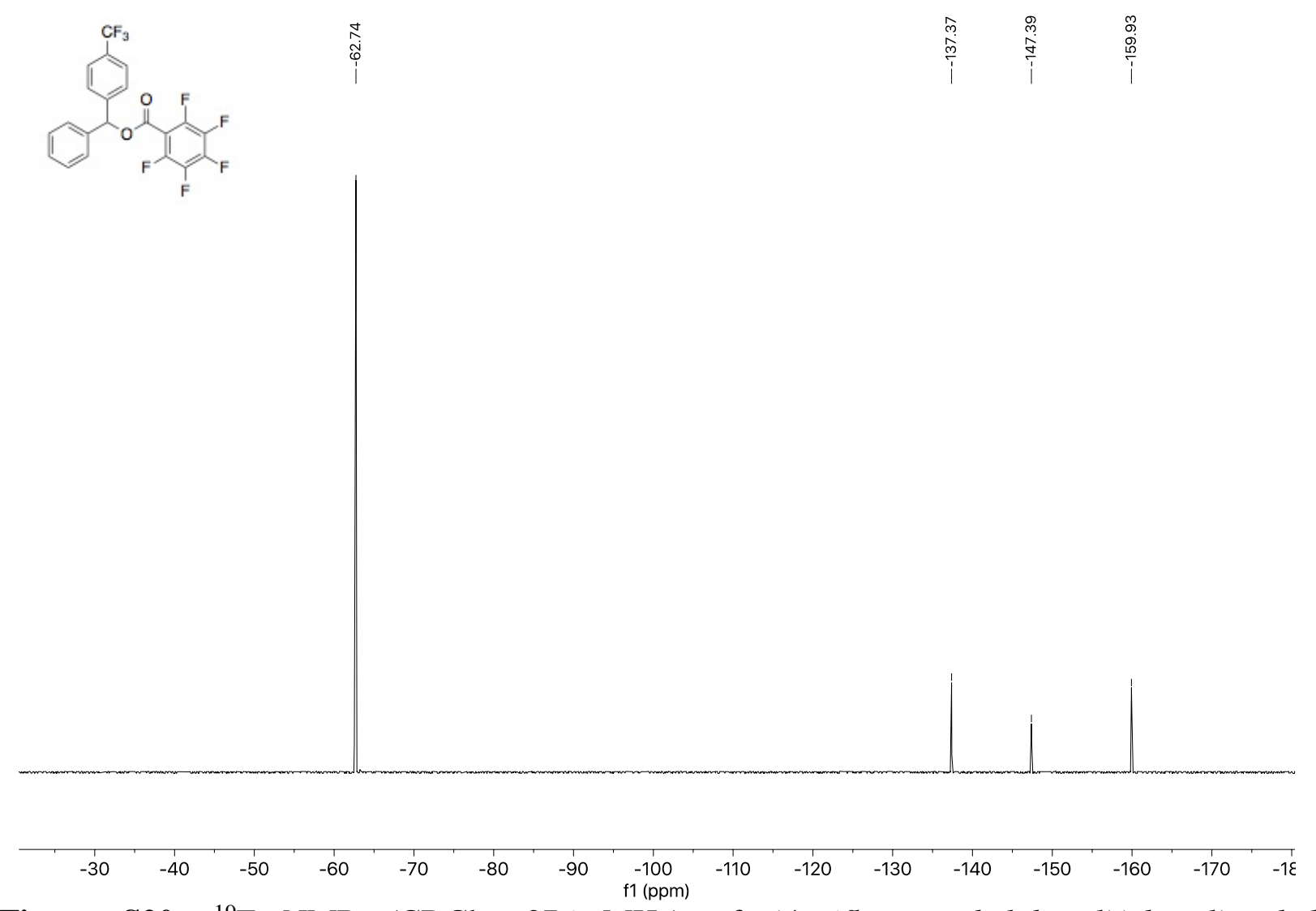

Figure S20: ${ }^{19} \mathrm{~F}$ NMR $\left(\mathrm{CDCl}_{3}, 376 \mathrm{MHz}\right)$ of (4-trifluoromethylphenyl)(phenyl)methyl pentafluorobenzoate 


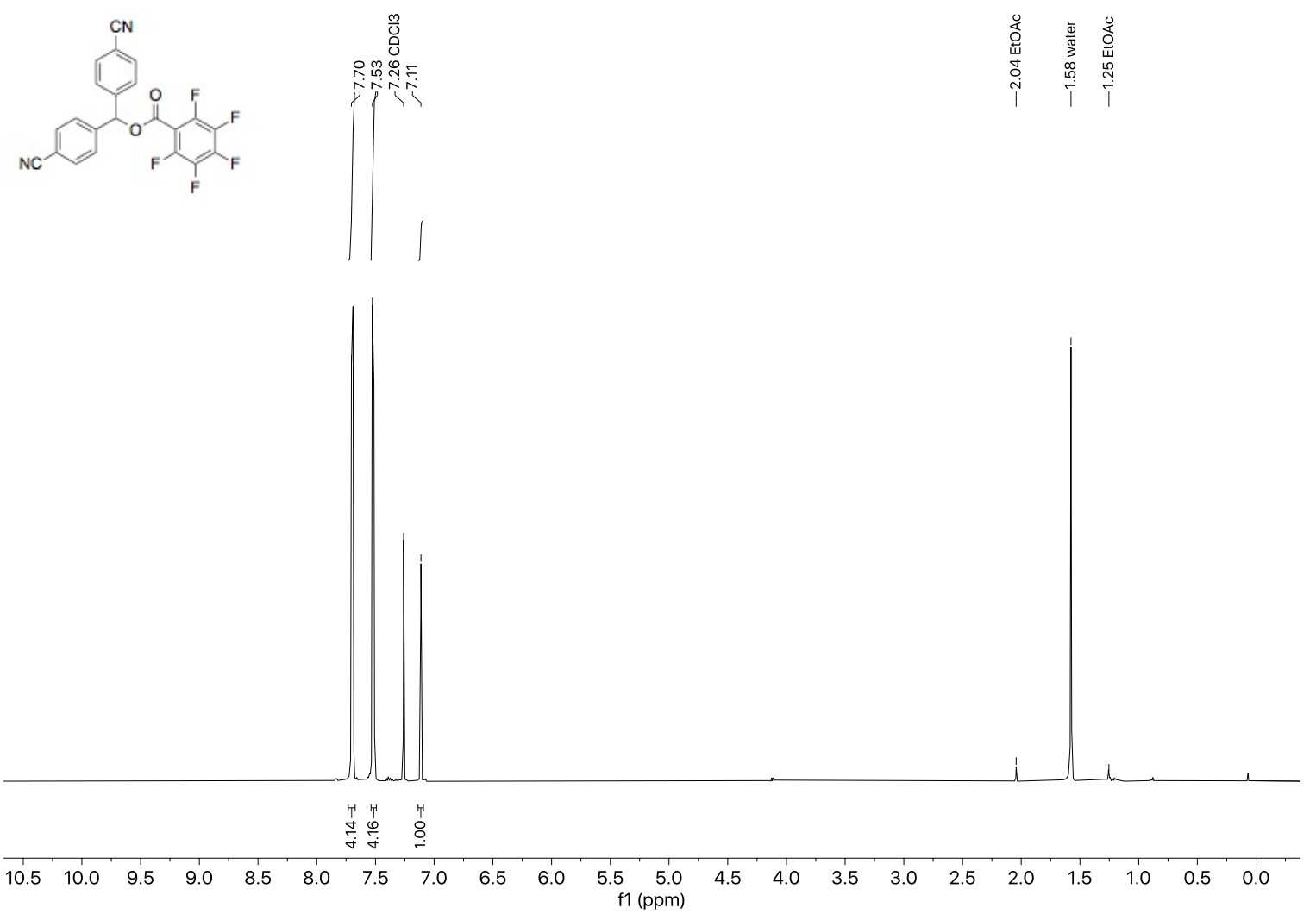

Figure S21: ${ }^{1} \mathrm{H} \mathrm{NMR}\left(\mathrm{CDCl}_{3}, 600 \mathrm{MHz}\right)$ of bis(4-cyanophenyl)methyl pentafluorobenzoate

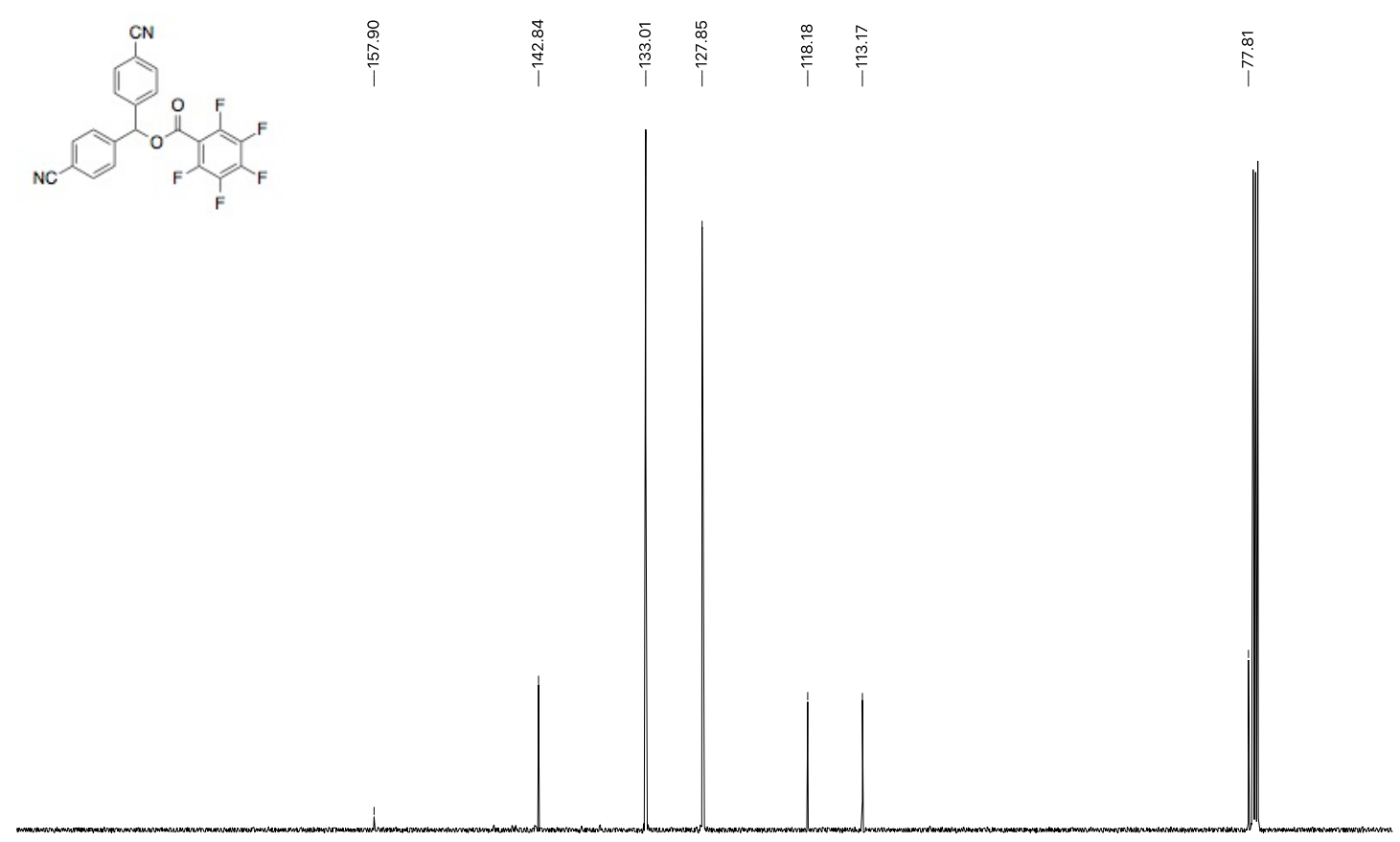

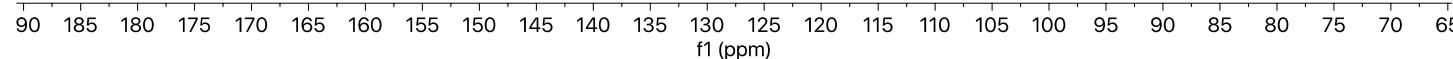

Figure S22: ${ }^{13} \mathrm{C}\left\{{ }^{1} \mathrm{H}\right\}$ NMR $\left(\mathrm{CDCl}_{3}, 151 \mathrm{MHz}\right)$ of bis(4-cyanophenyl)methyl pentafluorobenzoate 

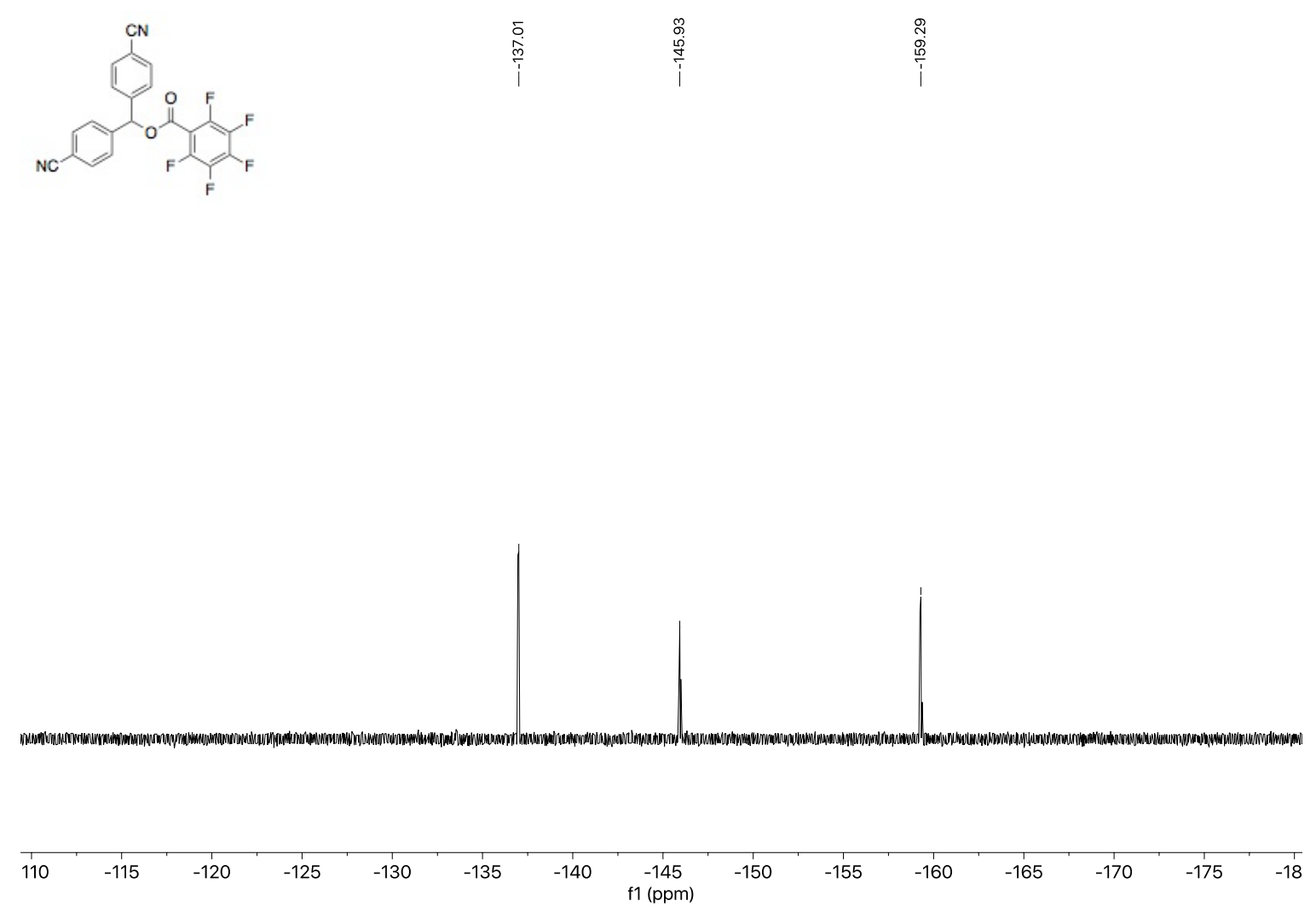

Figure S23: ${ }^{19} \mathrm{~F} \mathrm{NMR}\left(\mathrm{CDCl}_{3}, 376 \mathrm{MHz}\right)$ of bis(4-cyanophenyl)methyl pentafluorobenzoate 


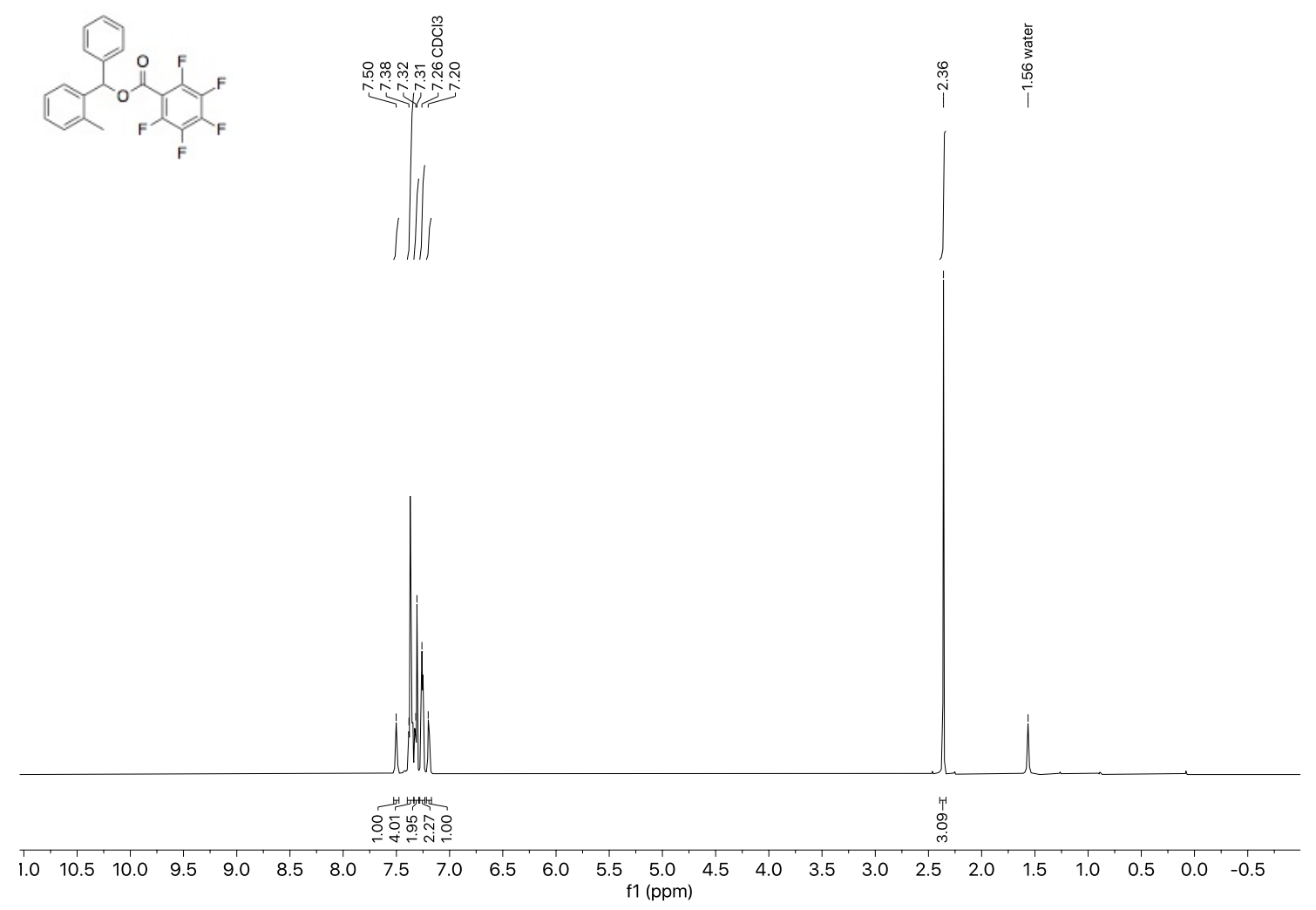

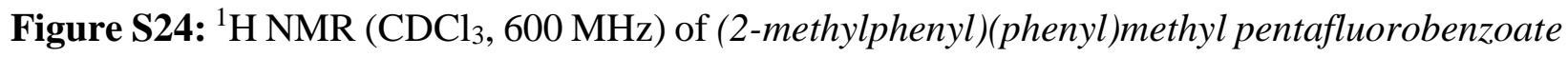



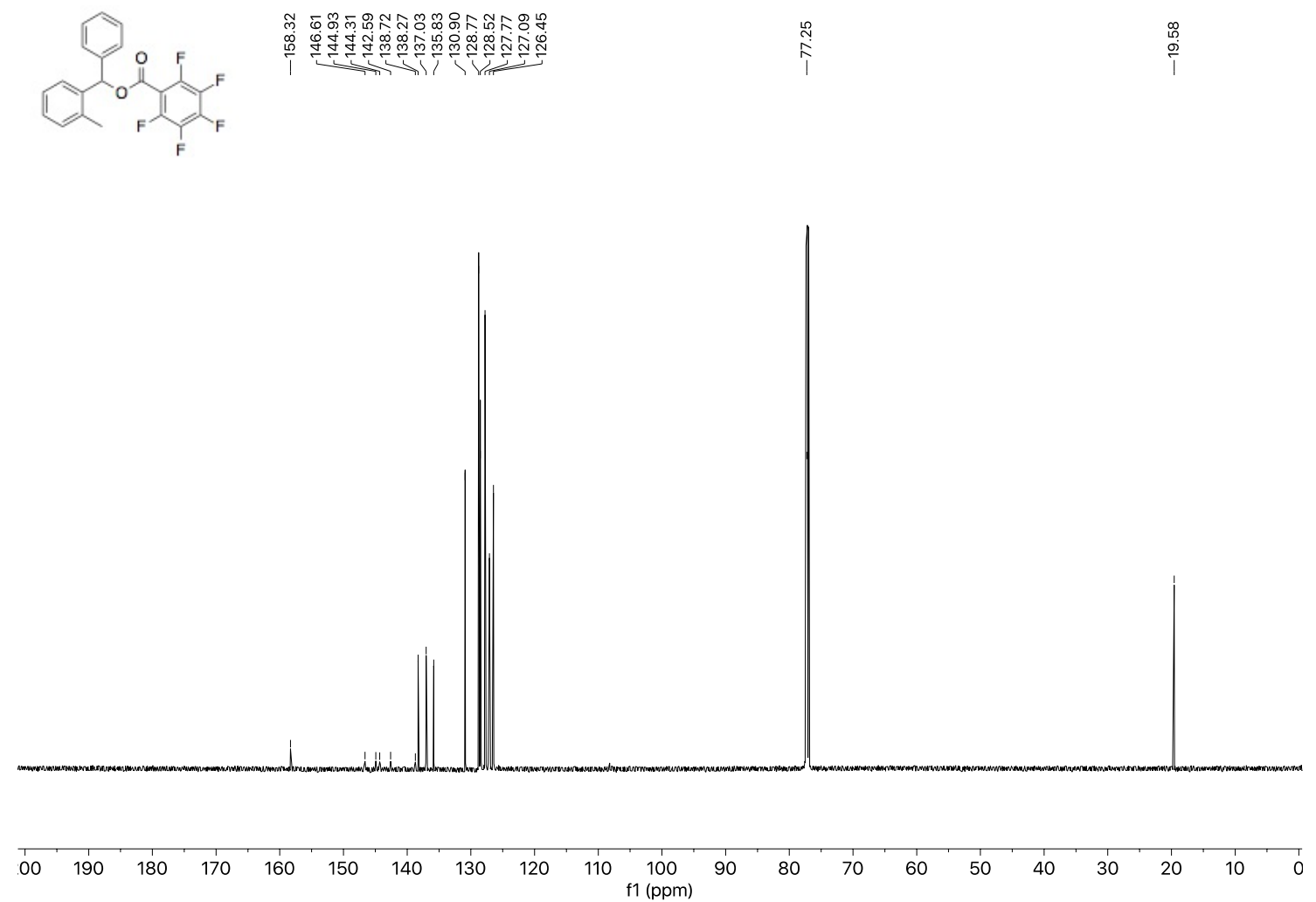

Figure S25: ${ }^{13} \mathrm{C}\left\{{ }^{1} \mathrm{H}\right\} \quad \mathrm{NMR} \quad\left(\mathrm{CDCl}_{3}, \quad 151 \mathrm{MHz}\right)$ of (2-methylphenyl)(phenyl)methyl pentafluorobenzoate 

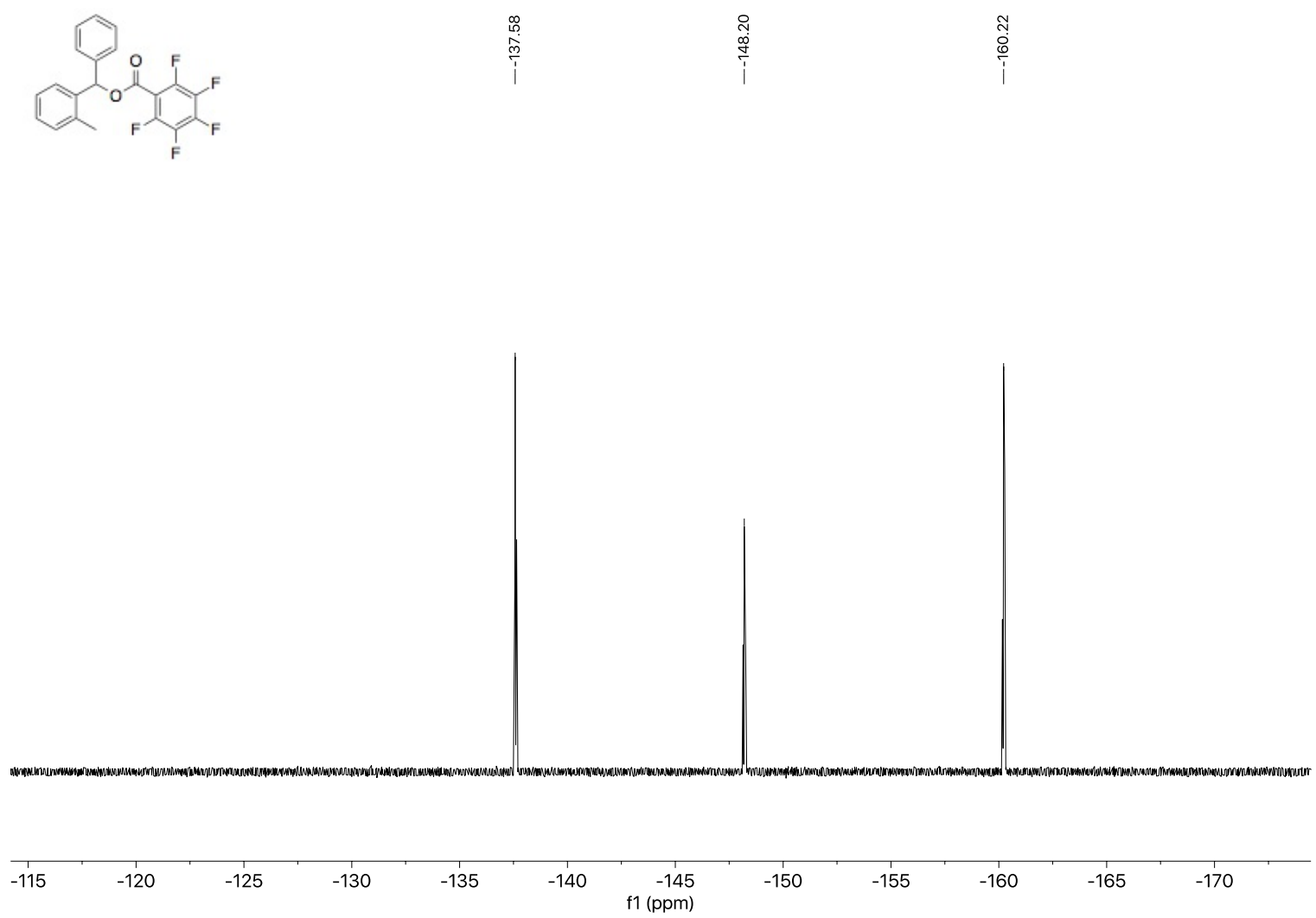

Figure S26: ${ }^{19} \mathrm{~F} \mathrm{NMR}\left(\mathrm{CDCl}_{3}, 376 \mathrm{MHz}\right)$ of (2-methylphenyl)(phenyl)methyl pentafluorobenzoate 


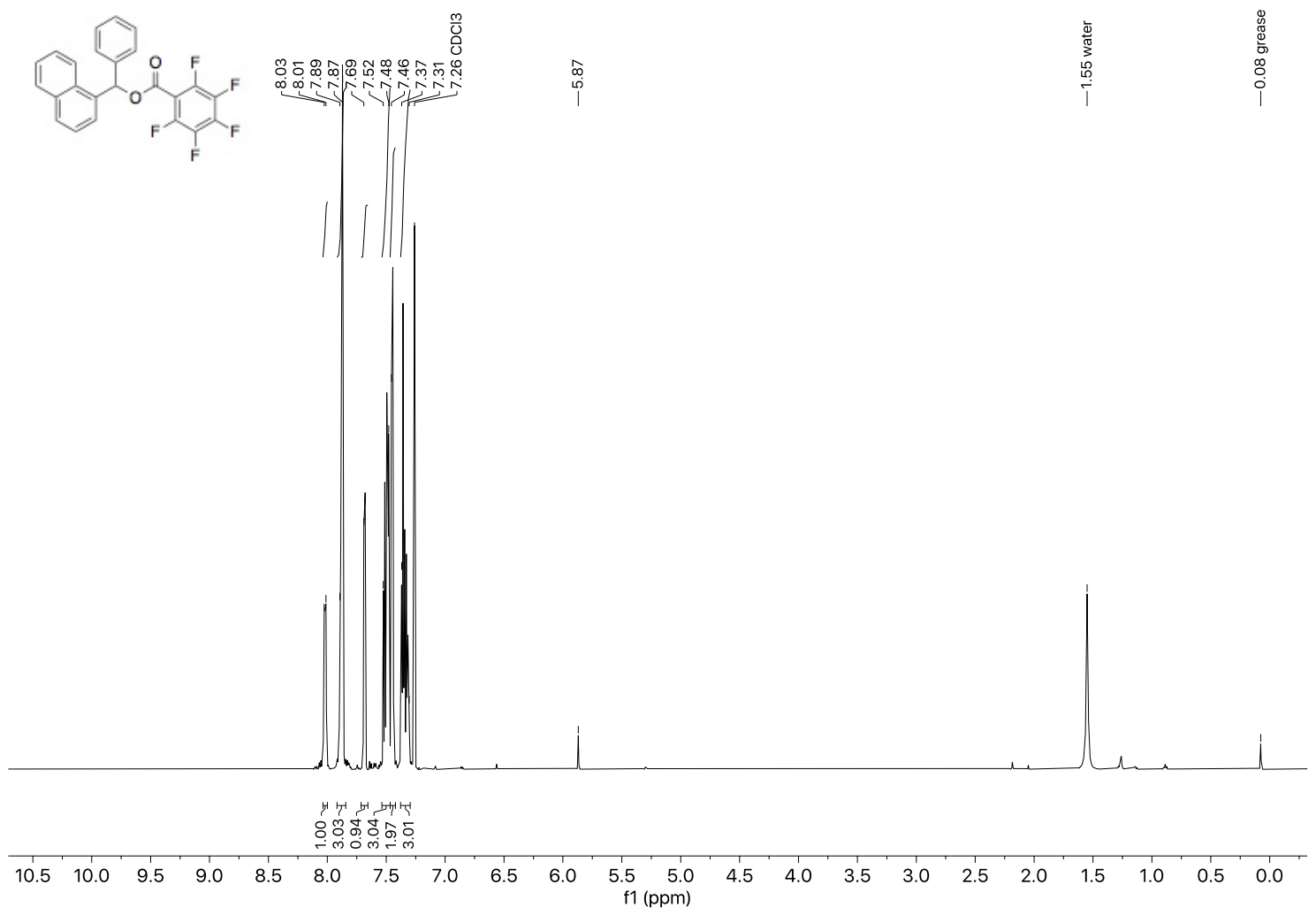

Figure S27: ${ }^{1} \mathrm{H} \mathrm{NMR}\left(\mathrm{CDCl}_{3}, 600 \mathrm{MHz}\right)$ of (1-naphthyl)(phenyl)methyl pentafluorobenzoate 

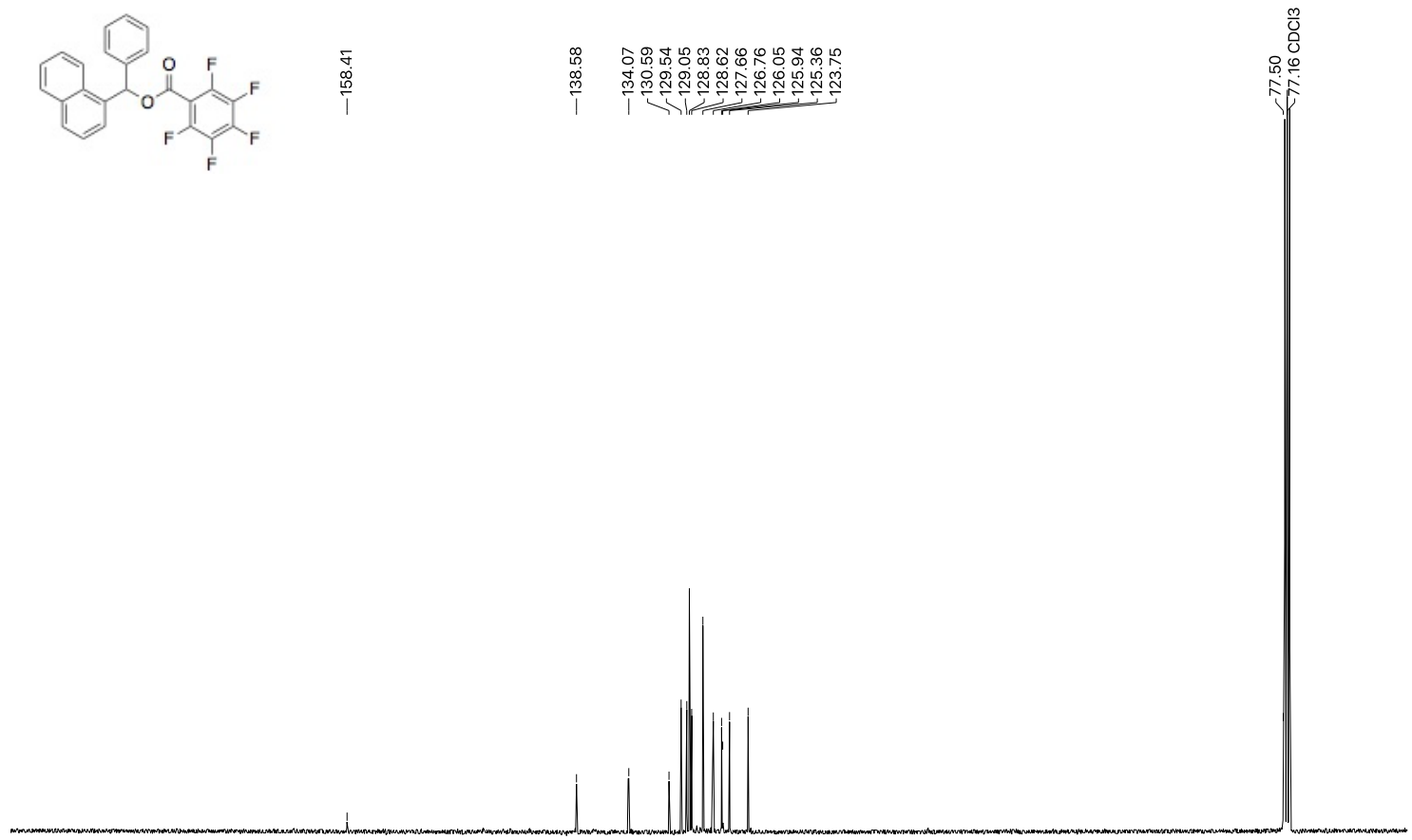

\begin{tabular}{llllllllllllllllllllllll}
\hline 185 & 180 & 175 & 170 & 165 & 160 & 155 & 150 & 145 & 140 & 135 & 130 & 125 & 120 & 115 & 110 & 105 & 100 & 95 & 90 & 85 & 80 & 75 & 70
\end{tabular}

Figure S28: ${ }^{13} \mathrm{C}\left\{{ }^{1} \mathrm{H}\right\} \quad \mathrm{NMR} \quad\left(\mathrm{CDCl}_{3}, \quad 151 \quad \mathrm{MHz}\right) \quad$ of $\quad(1$-naphthyl)(phenyl)methyl pentafluorobenzoate 


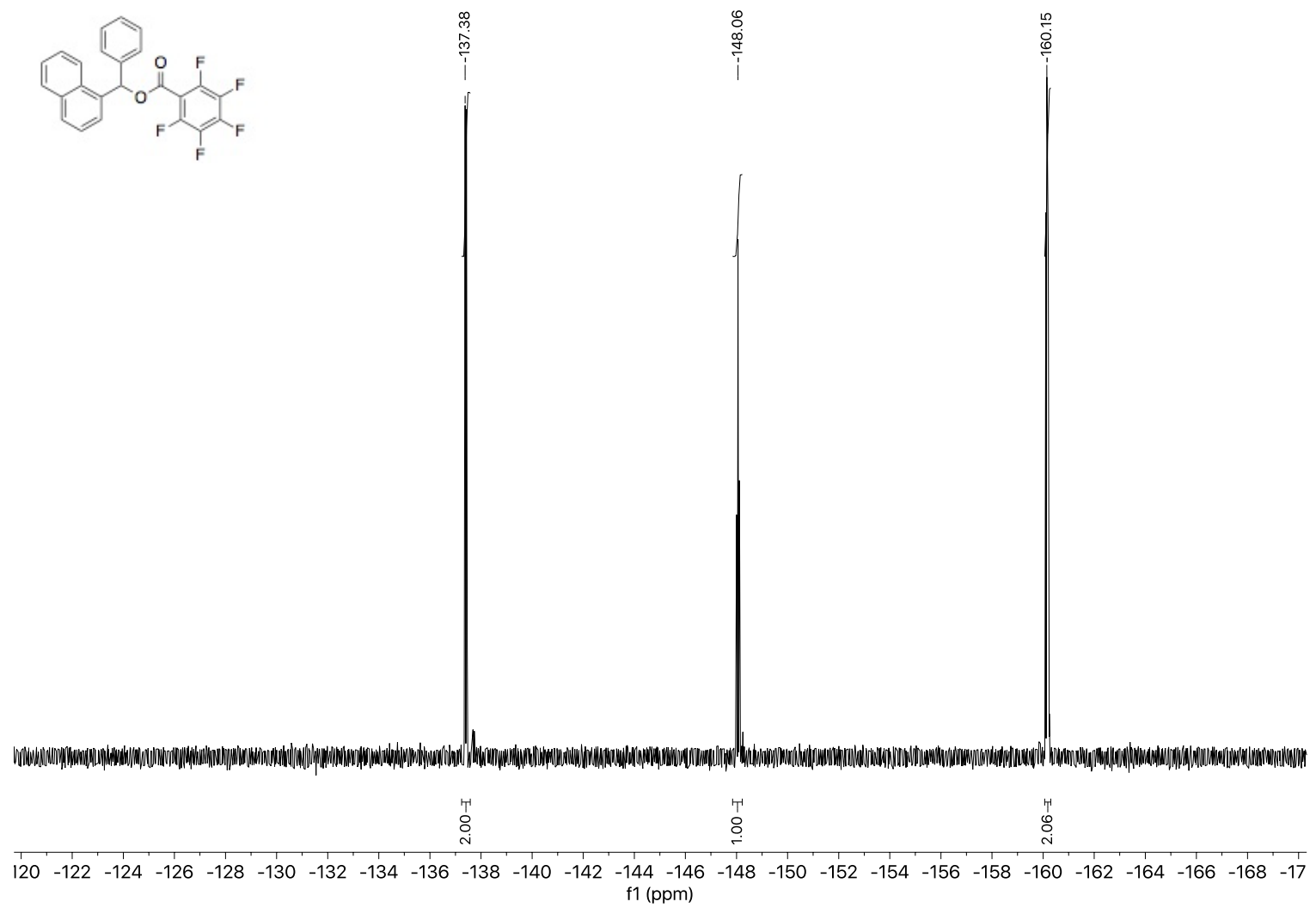

Figure S29: ${ }^{19} \mathrm{~F} \mathrm{NMR}\left(\mathrm{CDCl}_{3}, 376 \mathrm{MHz}\right)$ of (1-naphthyl)(phenyl)methyl pentafluorobenzoate 


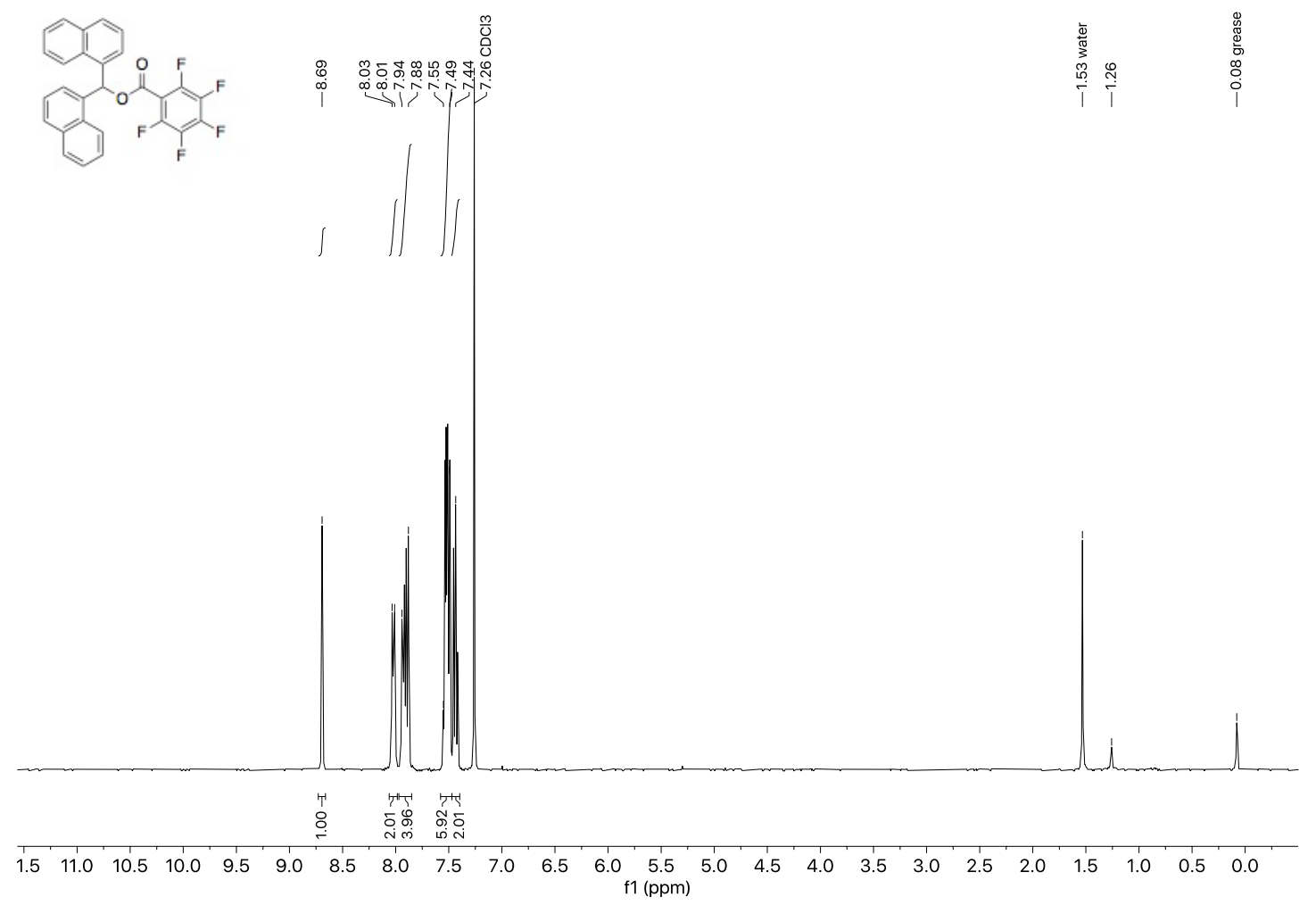

Figure S30: ${ }^{1} \mathrm{H} \mathrm{NMR}\left(\mathrm{CDCl}_{3}, 500 \mathrm{MHz}\right)$ of bis(1-naphthyl))methyl pentafluorobenzoate
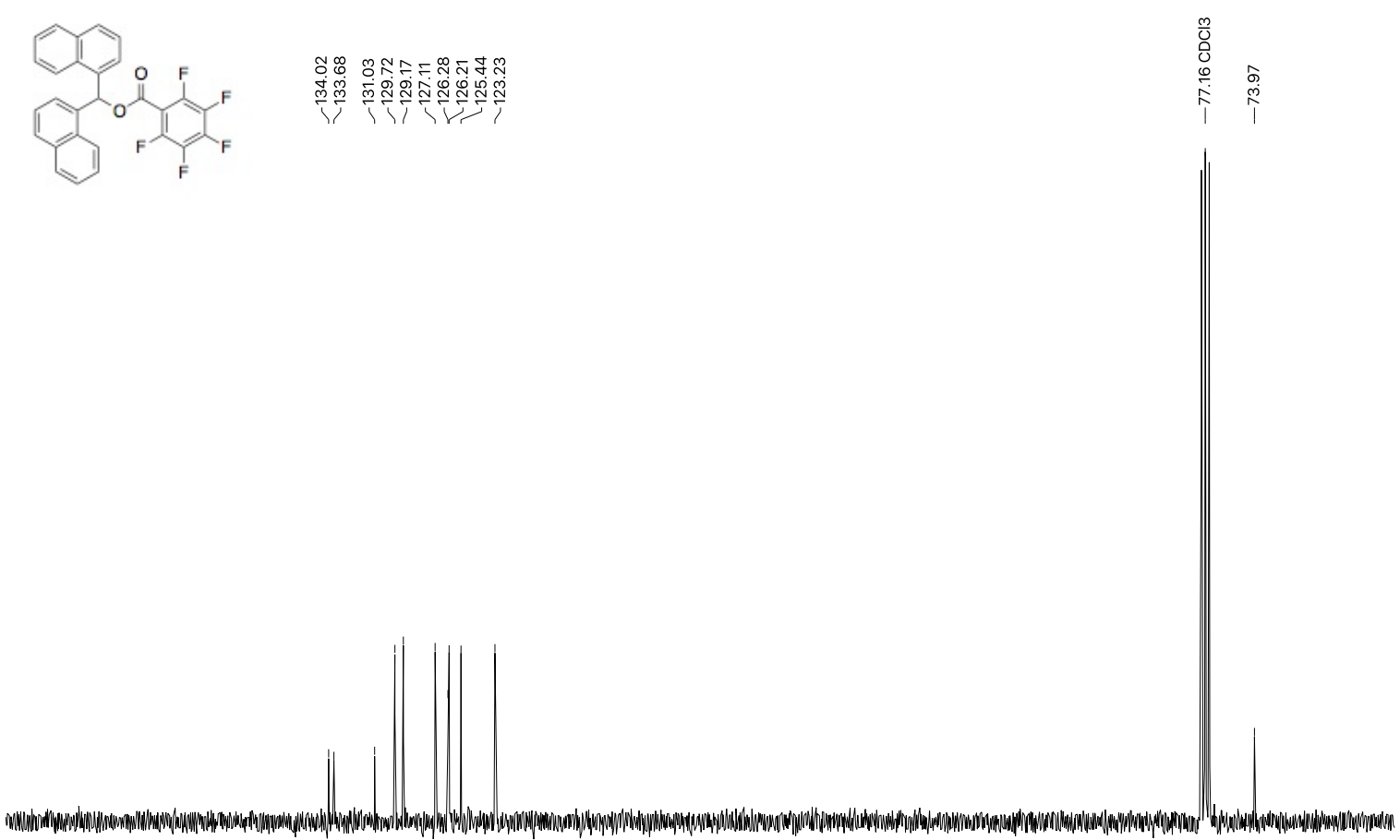

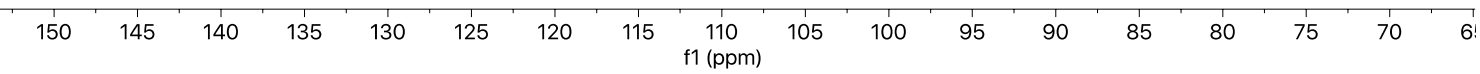

Figure S31: ${ }^{13} \mathrm{C}\left\{{ }^{1} \mathrm{H}\right\} \mathrm{NMR}\left(\mathrm{CDCl}_{3}, 126 \mathrm{MHz}\right)$ of bis(1-naphthyl))methyl pentafluorobenzoate 


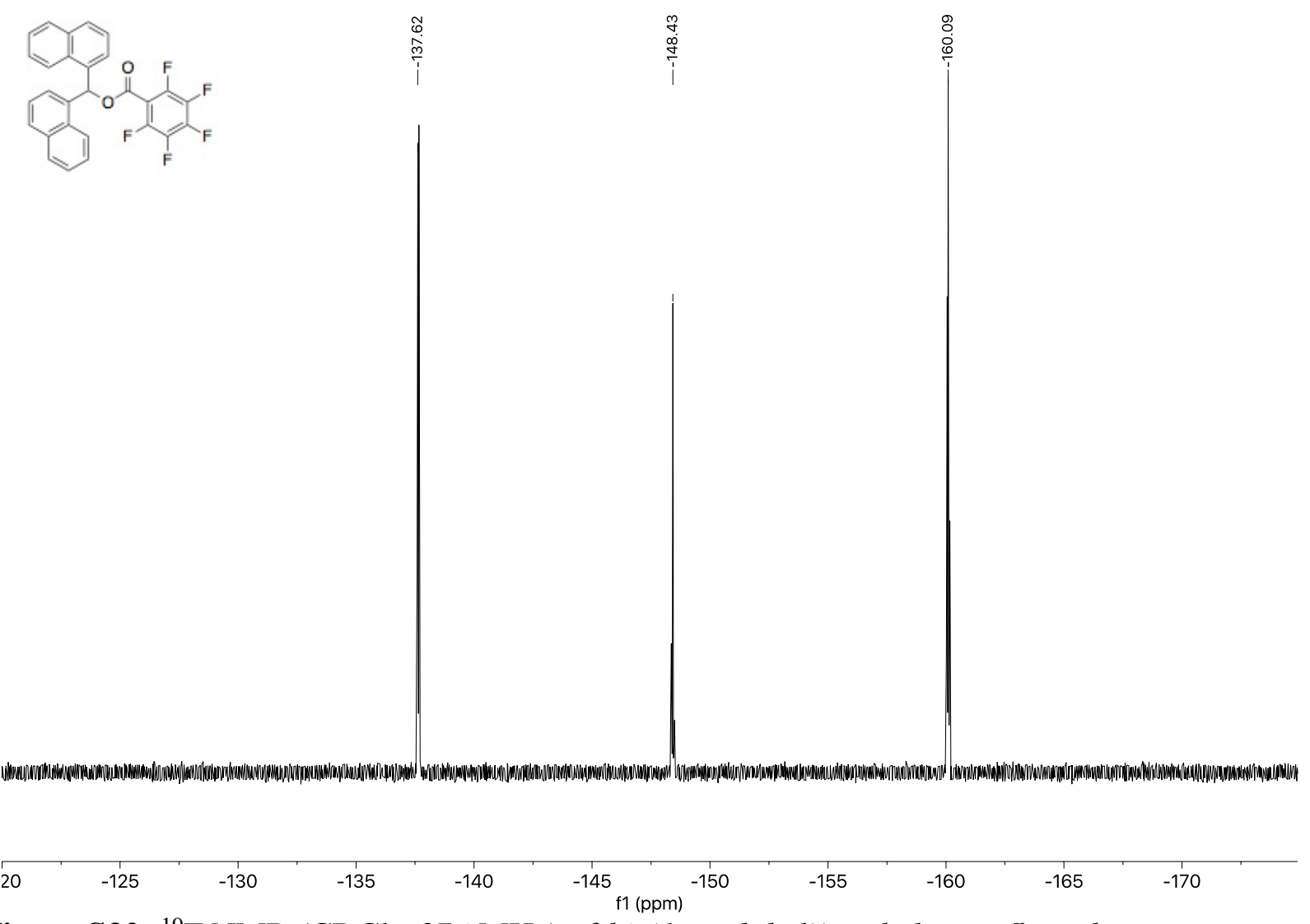

Figure S32: ${ }^{19} \mathrm{~F} \mathrm{NMR}\left(\mathrm{CDCl}_{3}, 376 \mathrm{MHz}\right)$ of bis(1-naphthyl))methyl pentafluorobenzoate 

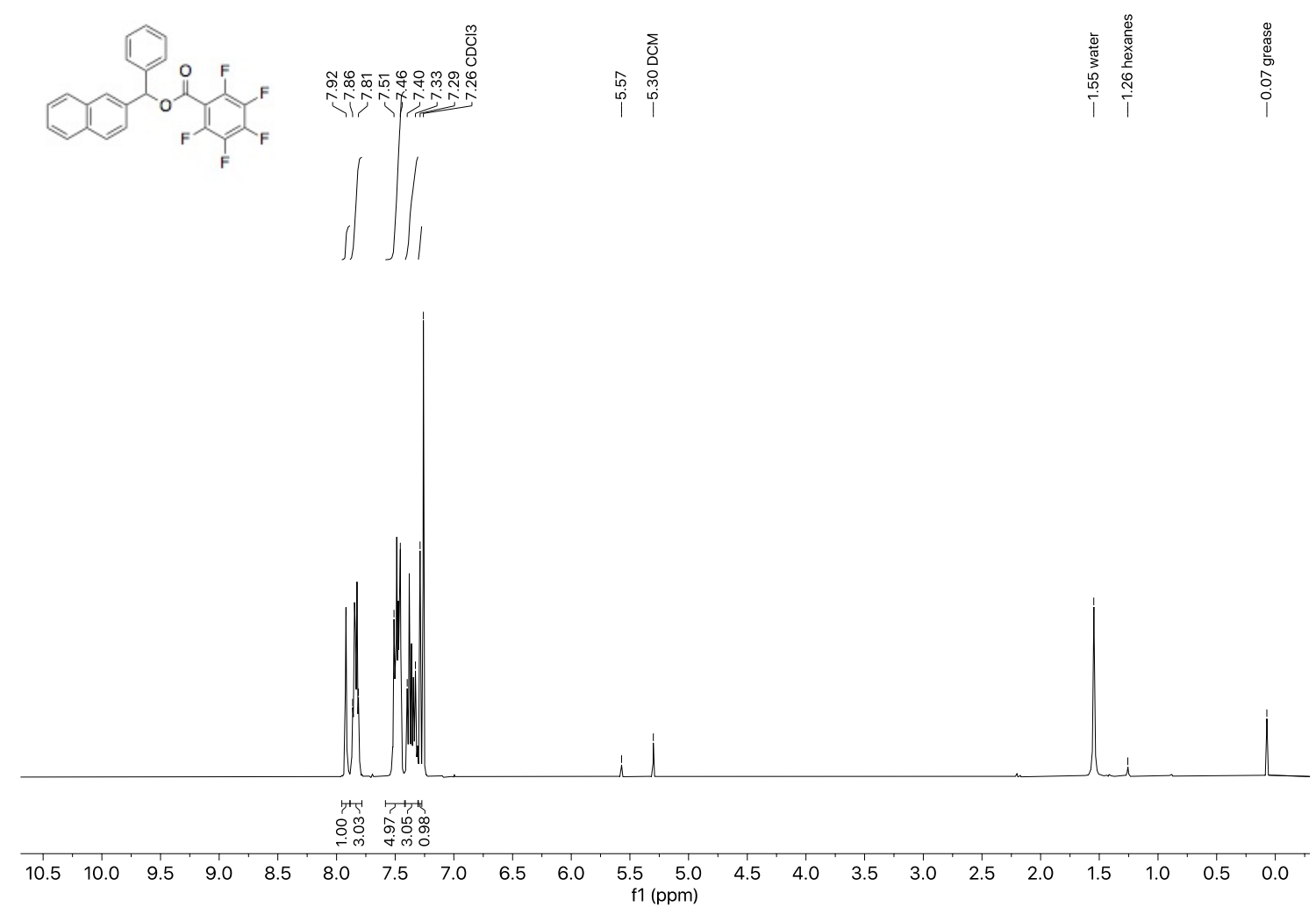

Figure S33: ${ }^{1} \mathrm{H} \mathrm{NMR}\left(\mathrm{CDCl}_{3}, 400 \mathrm{MHz}\right)$ of (2-naphthyl)(phenyl)methyl pentafluorobenzoate 


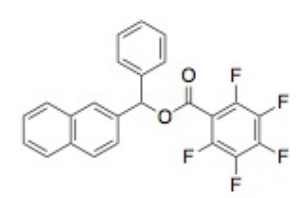

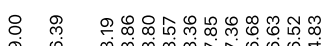

i.

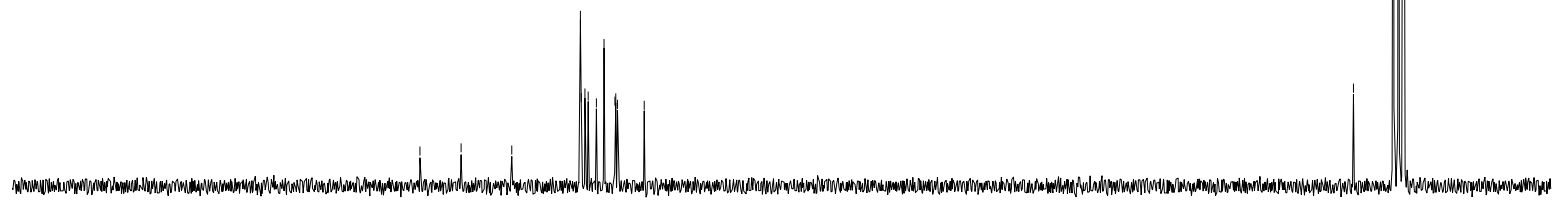

$\begin{array}{lllll}160 & 155 & 150 & 145 & 140\end{array}$

$135 \quad 130$

$120 \quad 115$

$\begin{array}{lllllllll}110 & 105 & 100 & 95 & 90 & 85 & 80 & 75 & 70\end{array}$

Figure S34: ${ }^{13} \mathrm{C}\left\{{ }^{1} \mathrm{H}\right\} \quad \mathrm{NMR} \quad\left(\mathrm{CDCl}_{3},{ }^{101} \mathrm{MHz}\right)$ of (2-naphthyl)(phenyl)methyl pentafluorobenzoate 


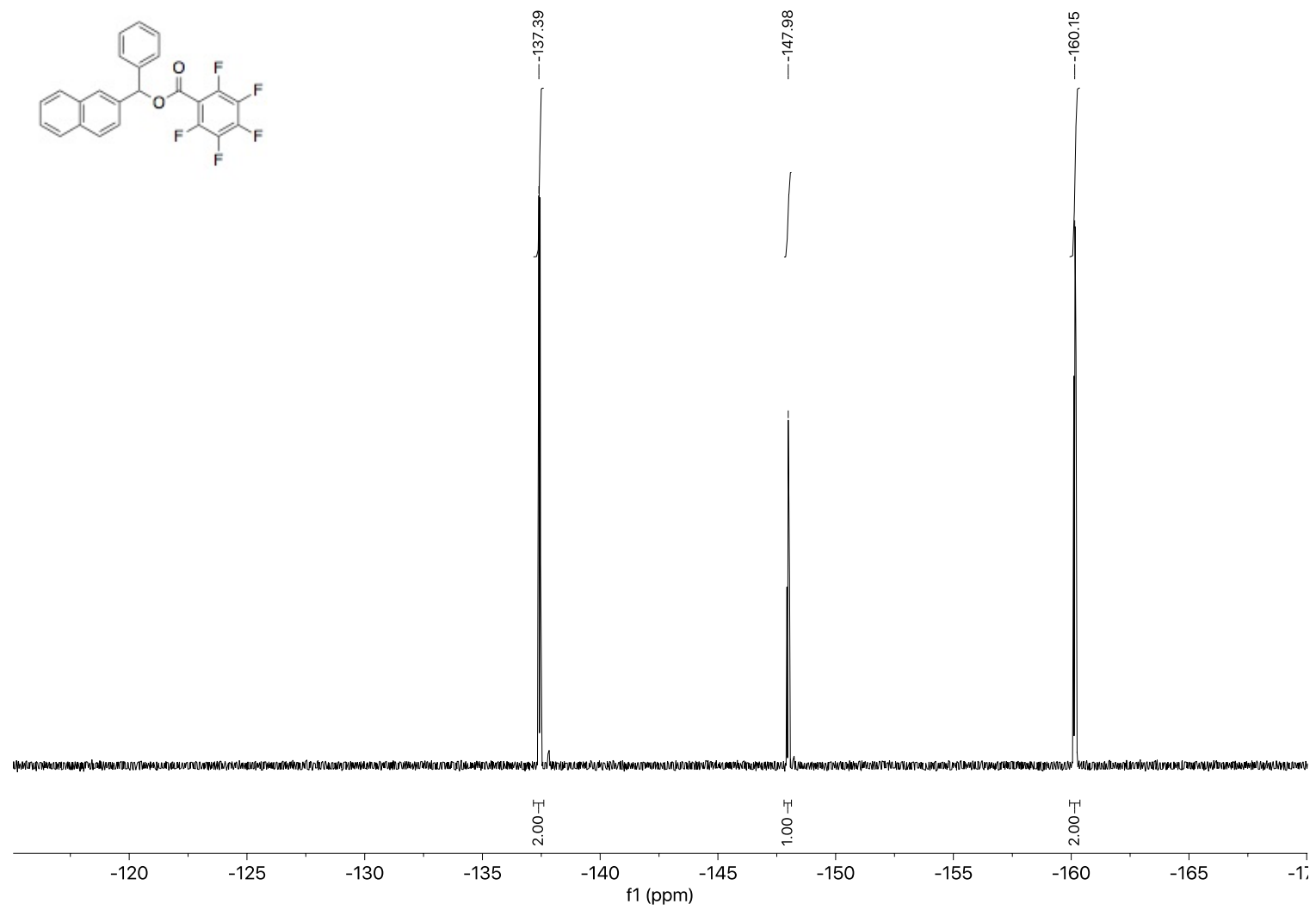

Figure S35: ${ }^{19} \mathrm{~F}$ NMR $\left(\mathrm{CDCl}_{3}, 376 \mathrm{MHz}\right)$ of (2-naphthyl)(phenyl)methyl pentafluorobenzoate 

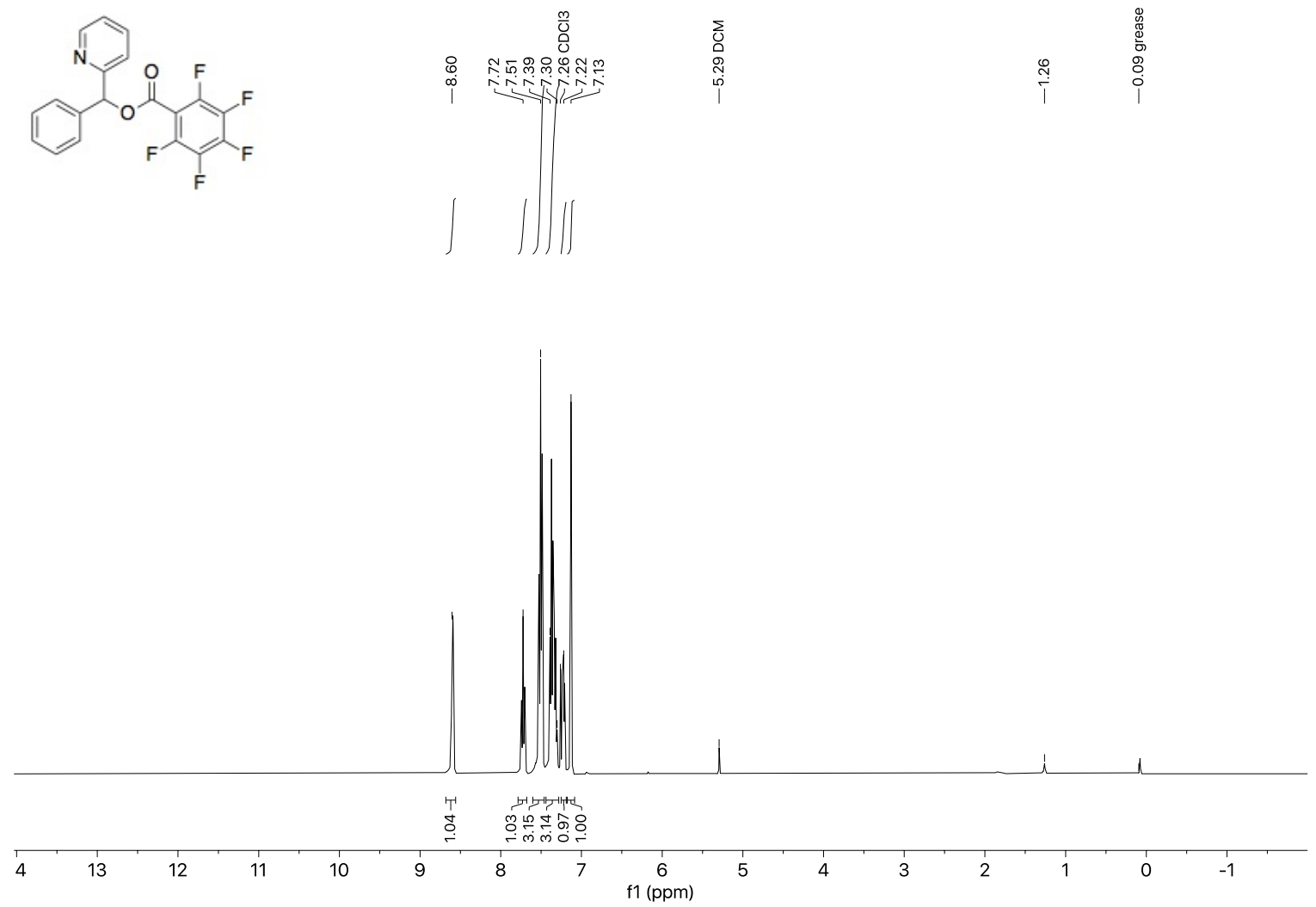

Figure S36: ${ }^{1} \mathrm{H} \mathrm{NMR}\left(\mathrm{CDCl}_{3}, 400 \mathrm{MHz}\right)$ of (phenyl)(2-pyridyl)methyl pentafluorobenzoate 

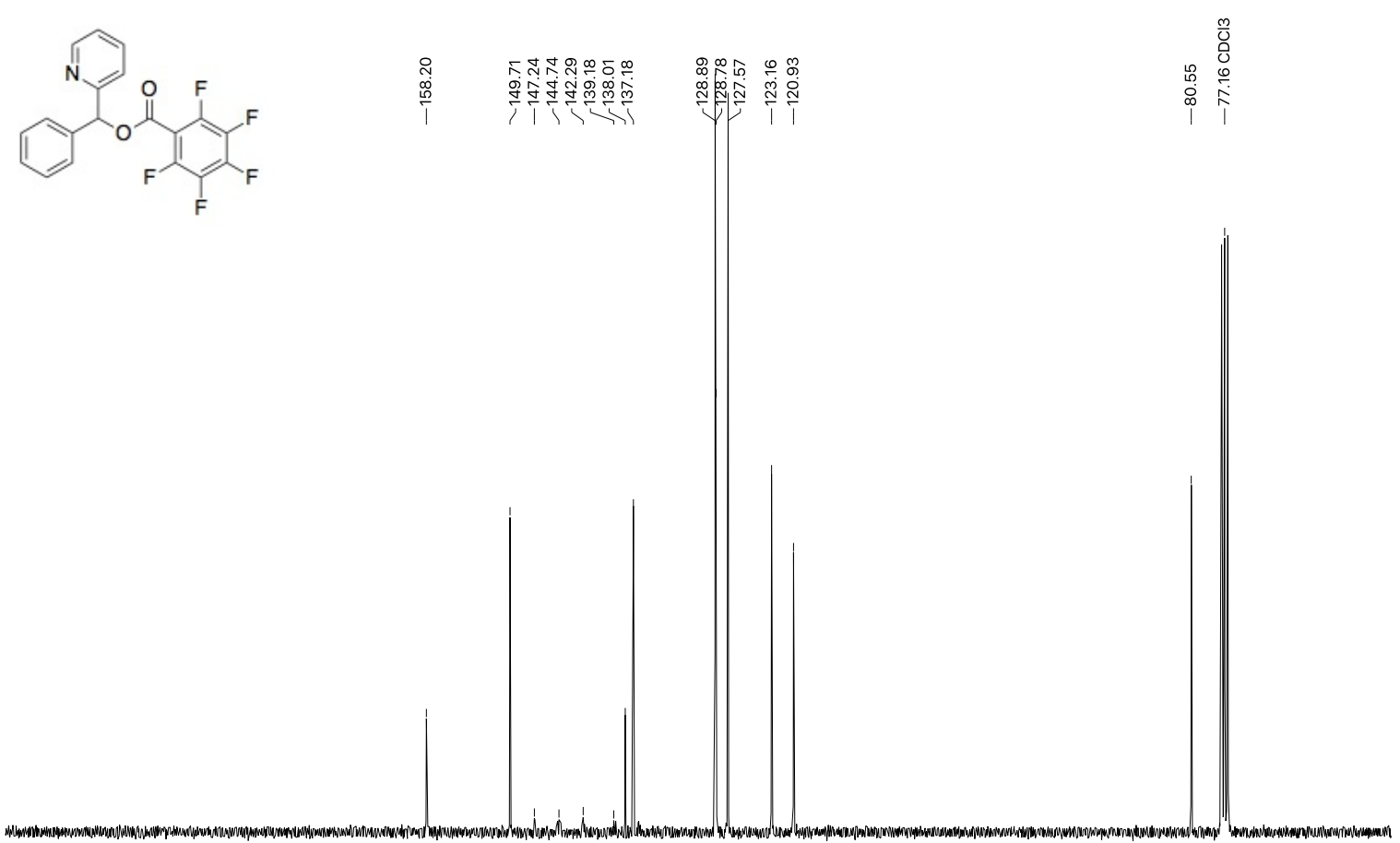

$\begin{array}{llllllllllllllllllllllllllllllllllllllllll}00 & 195 & 190 & 185 & 180 & 175 & 170 & 165 & 160 & 155 & 150 & 145 & 140 & 135 & 130 & 125 & 120 & 115 & 110 & 105 & 100 & 95 & 90 & 85 & 80 & 75 & 70 & 65 & \mathrm{f} 1(\mathrm{ppm}) & \end{array}$

Figure S37: ${ }^{13} \mathrm{C}\left\{{ }^{1} \mathrm{H}\right\} \mathrm{NMR}\left(\mathrm{CDCl}_{3}, 101 \mathrm{MHz}\right)$ of (phenyl)(2-pyridyl)methyl pentafluorobenzoate 


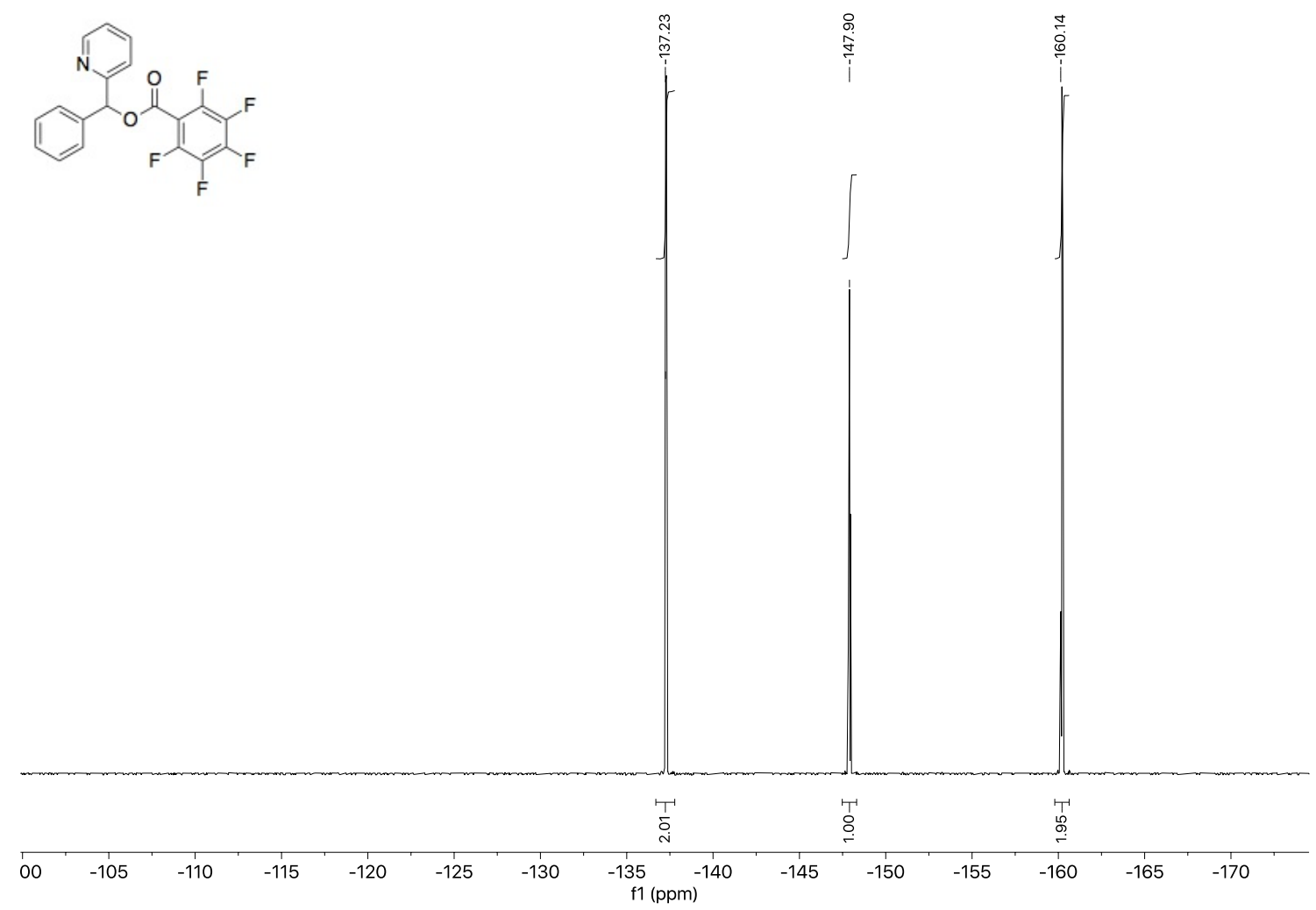

Figure S38: ${ }^{19} \mathrm{~F} \mathrm{NMR}\left(\mathrm{CDCl}_{3}, 376 \mathrm{MHz}\right)$ of (phenyl)(2-pyridyl)methyl pentafluorobenzoate 


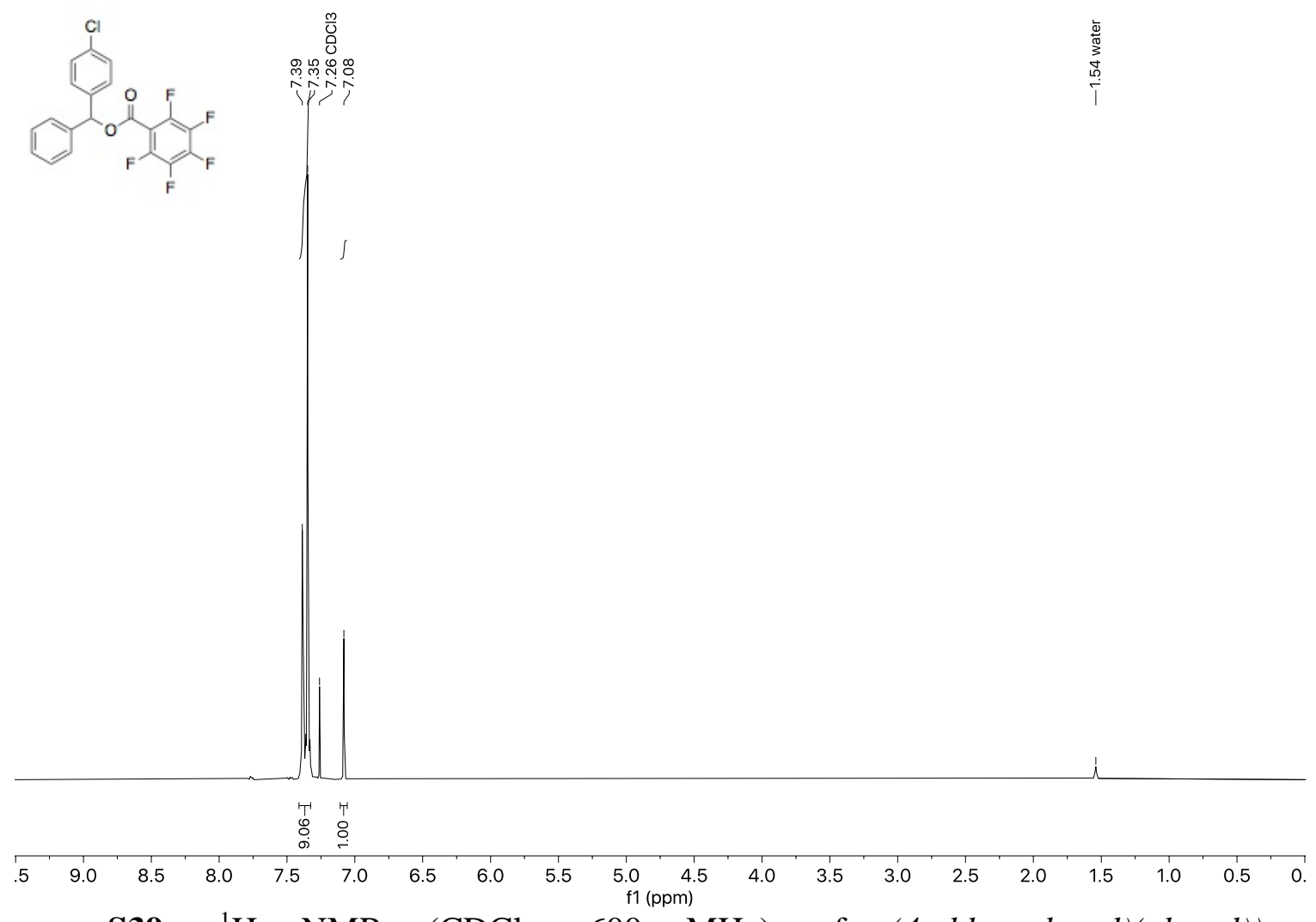

Figure S39: ${ }^{1} \mathrm{H} \quad \mathrm{NMR} \quad\left(\mathrm{CDCl}_{3}, \quad 600 \quad \mathrm{MHz}\right)$ of (4-chlorophenyl)(phenyl))methyl pentafluorobenzoate 

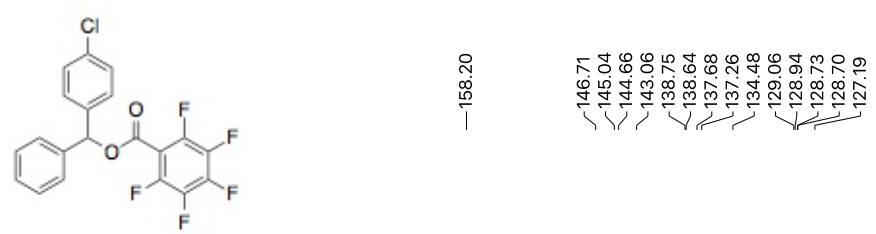

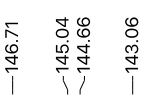

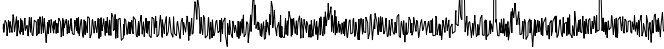

150

145

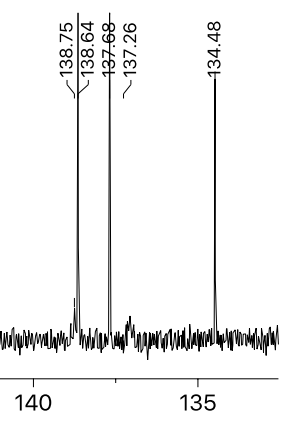

135

1 (

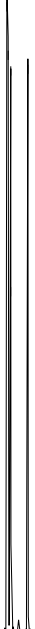

$\begin{array}{llllllllllllllll}\text { J0 } & 195 & 190 & 185 & 180 & 175 & 170 & 165 & 160 & 155 & 150 & 145 & 140 & 135 & 130 & 125\end{array}$

Figure S40: ${ }^{13} \mathrm{C}\left\{{ }^{1} \mathrm{H}\right\} \quad \mathrm{NMR} \quad\left(\mathrm{CDCl}_{3}, \quad 151 \mathrm{MHz}\right)$ of (4-chlorophenyl)(phenyl))methyl pentafluorobenzoate 


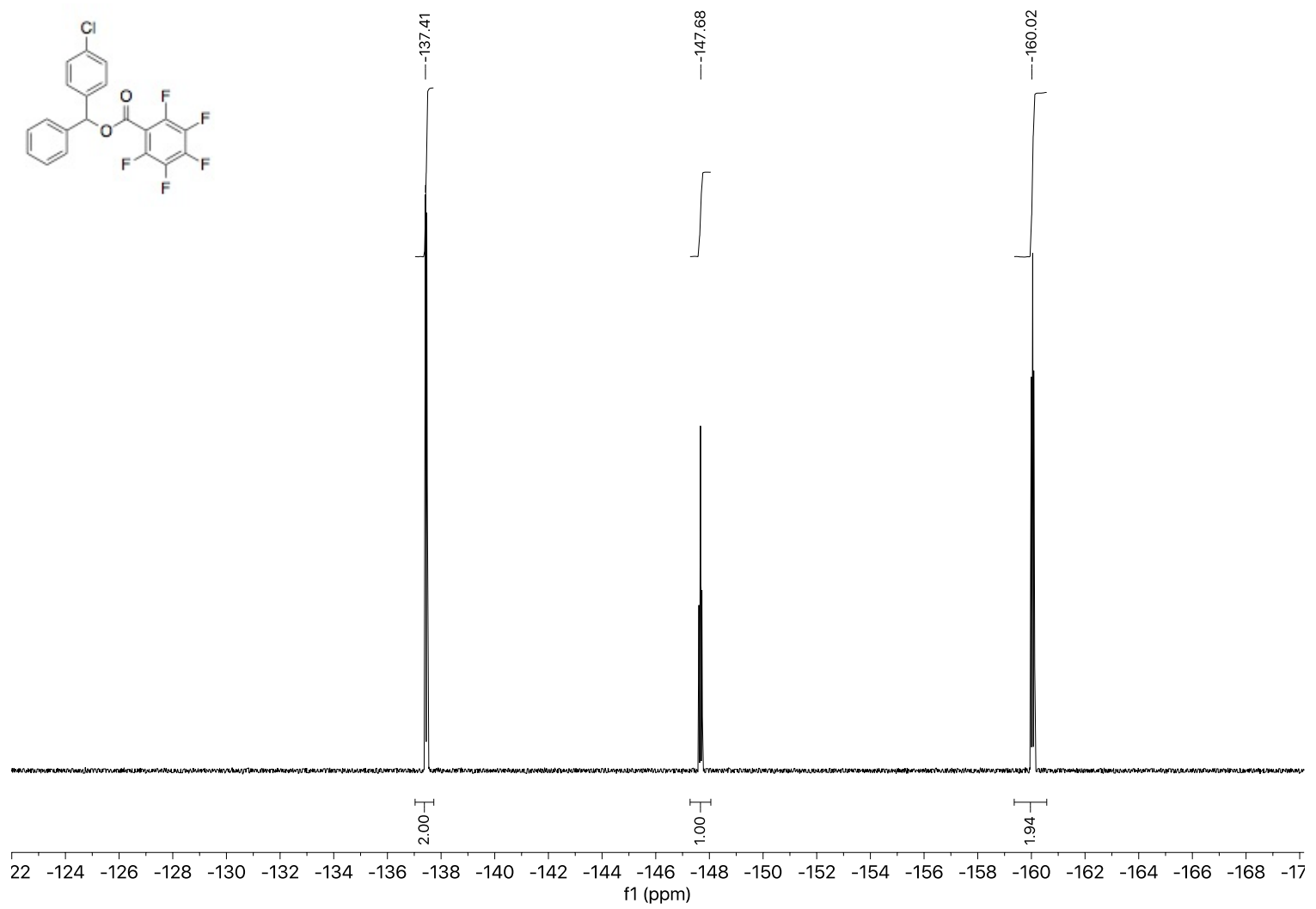

Figure S41: ${ }^{19} \mathrm{~F} \quad \mathrm{NMR} \quad\left(\mathrm{CDCl}_{3}, \quad 376 \mathrm{MHz}\right)$ of (4-chlorophenyl)(phenyl))methyl pentafluorobenzoate 


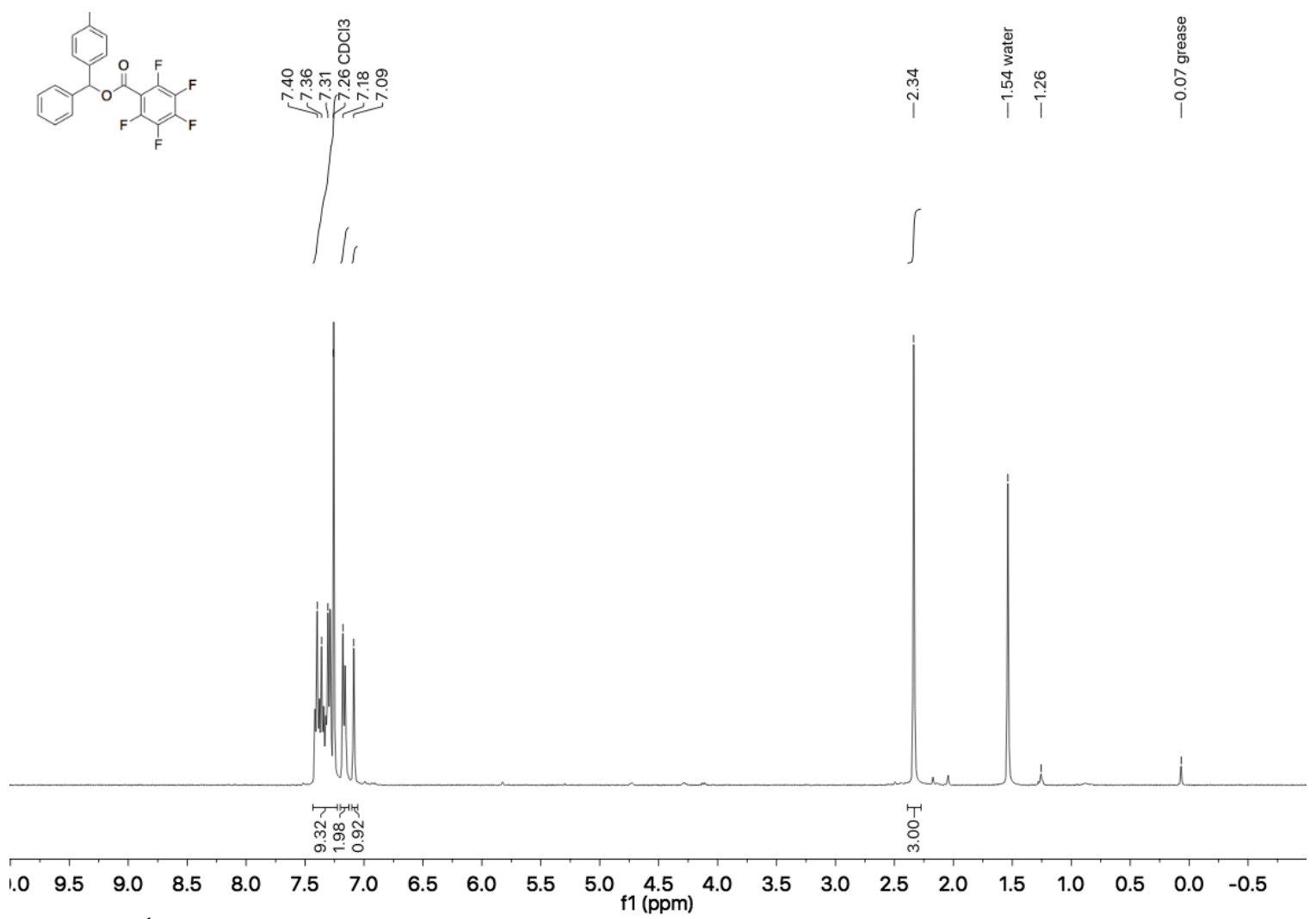

Figure S42: ${ }^{1} \mathrm{H} \mathrm{NMR}\left(\mathrm{CDCl}_{3}, 400 \mathrm{MHz}\right)$ of (4-methylphenyl)(phenyl)methyl pentafluorobenzoate 

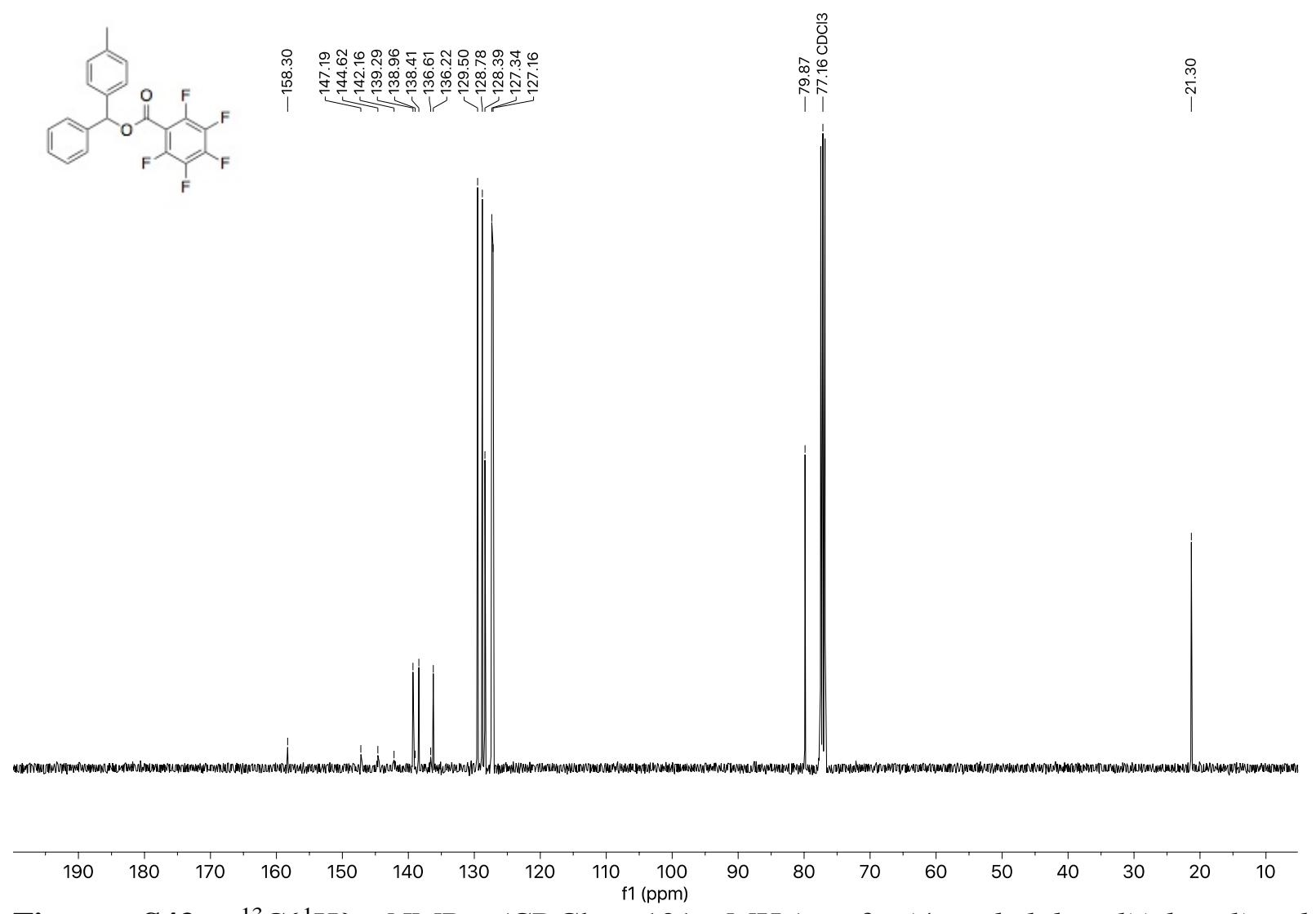

Figure S43: ${ }^{13} \mathrm{C}\left\{{ }^{1} \mathrm{H}\right\} \quad \mathrm{NMR} \quad\left(\mathrm{CDCl}_{3}, \quad 101 \mathrm{MHz}\right)$ of (4-methylphenyl)(phenyl)methyl pentafluorobenzoate 


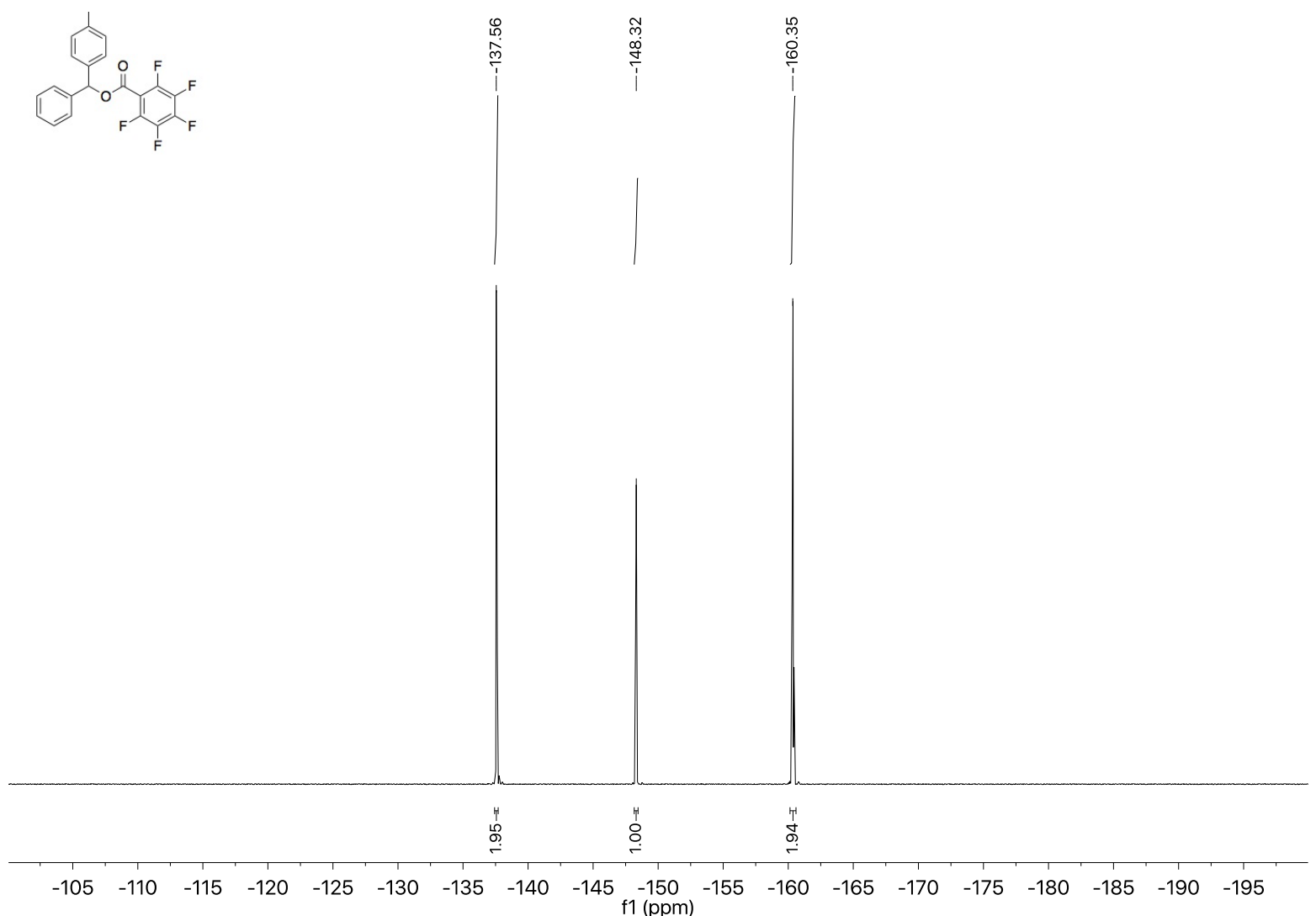

Figure S44: ${ }^{19} \mathrm{~F} \mathrm{NMR}\left(\mathrm{CDCl}_{3}, 376 \mathrm{MHz}\right)$ of (4-methylphenyl)(phenyl)methyl pentafluorobenzoate 

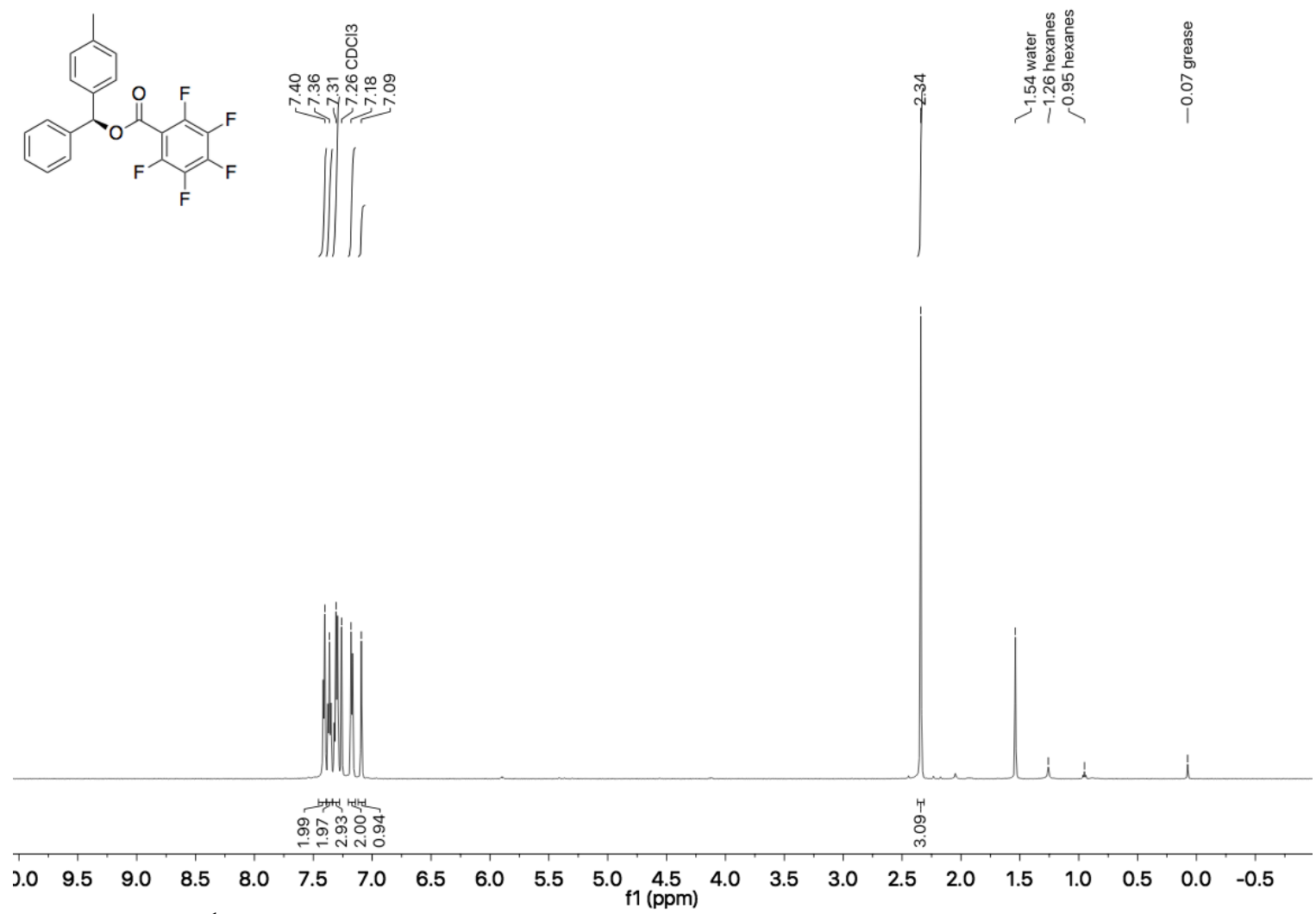

Figure S45: $\quad{ }^{1} \mathrm{H} \quad \mathrm{NMR} \quad\left(\mathrm{CDCl}_{3}, \quad 600 \mathrm{MHz}\right) \quad$ of $\quad(S)$-(4-methylphenyl)(phenyl)methyl pentafluorobenzoate 

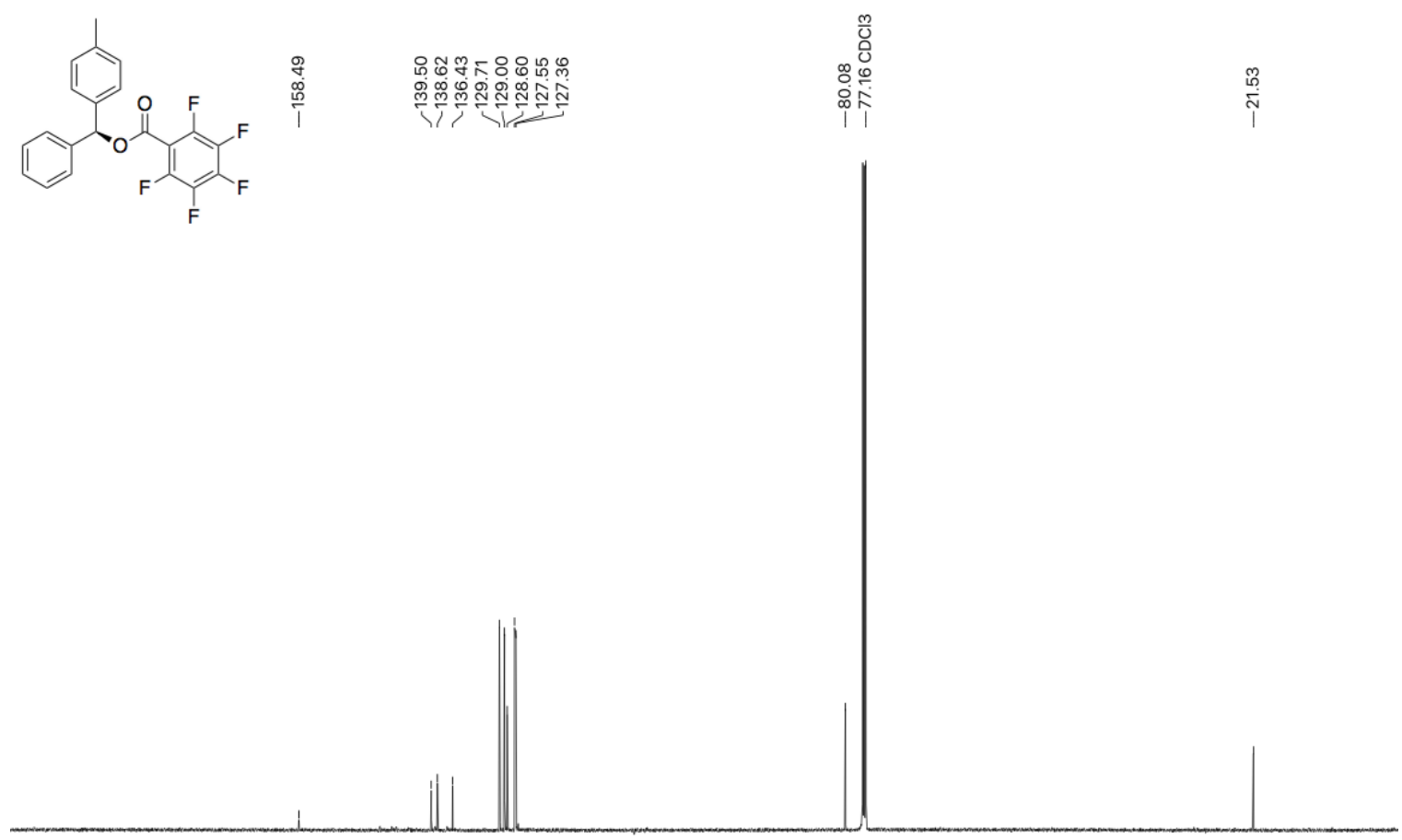

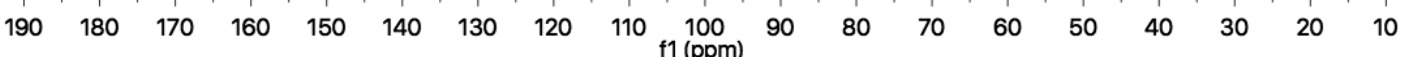

Figure S46: ${ }^{13} \mathrm{C}\left\{{ }^{1} \mathrm{H}\right\} \quad \mathrm{NMR} \quad\left(\mathrm{CDCl}_{3}, 151 \mathrm{MHz}\right)$ of (S)-(4-methylphenyl)(phenyl)methyl pentafluorobenzoate 

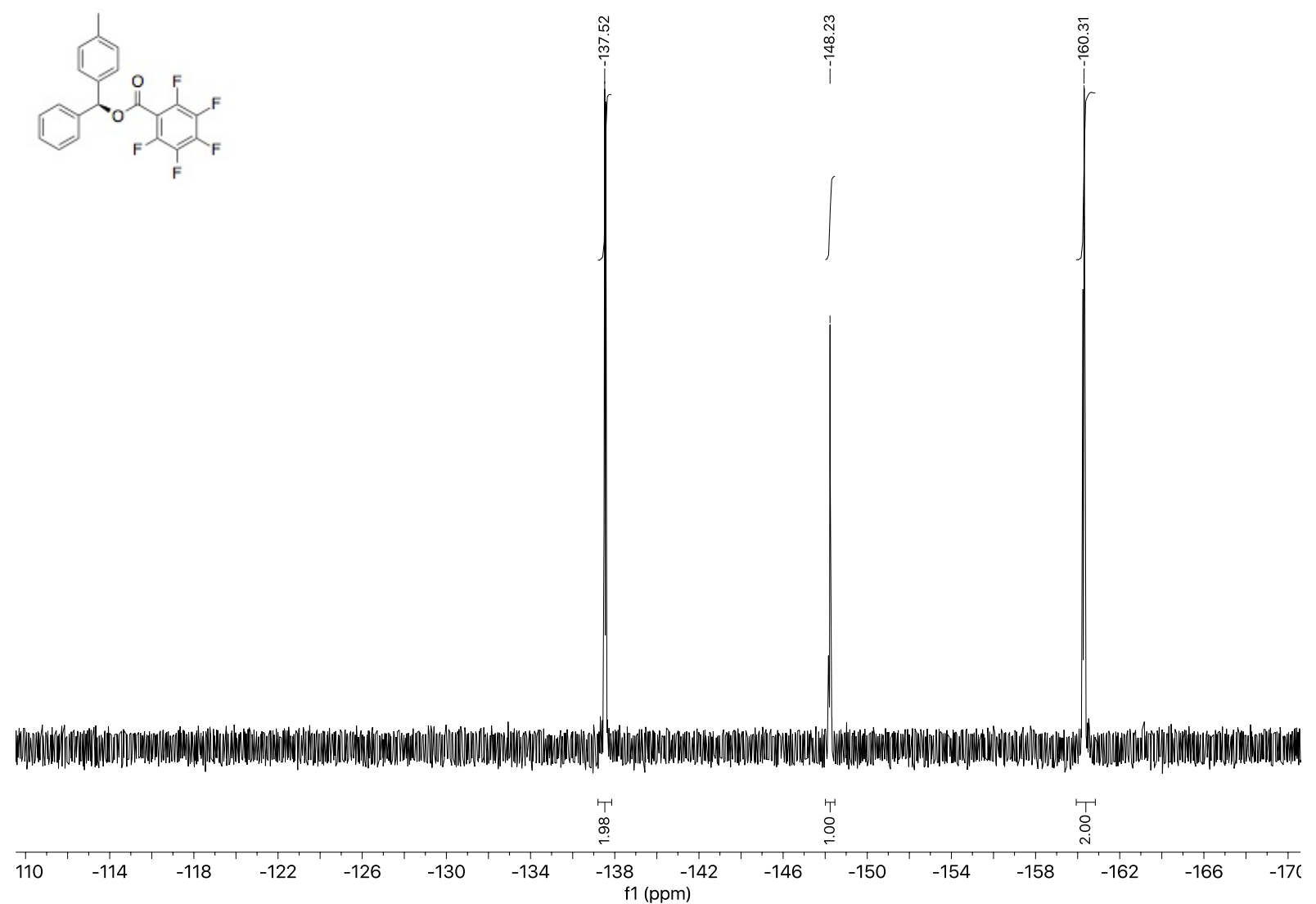

Figure S47: ${ }^{19} \mathrm{~F} \quad \mathrm{NMR} \quad\left(\mathrm{CDCl}_{3}, \quad 376 \mathrm{MHz}\right)$ of $($ S)-(4-methylphenyl)(phenyl)methyl pentafluorobenzoate 

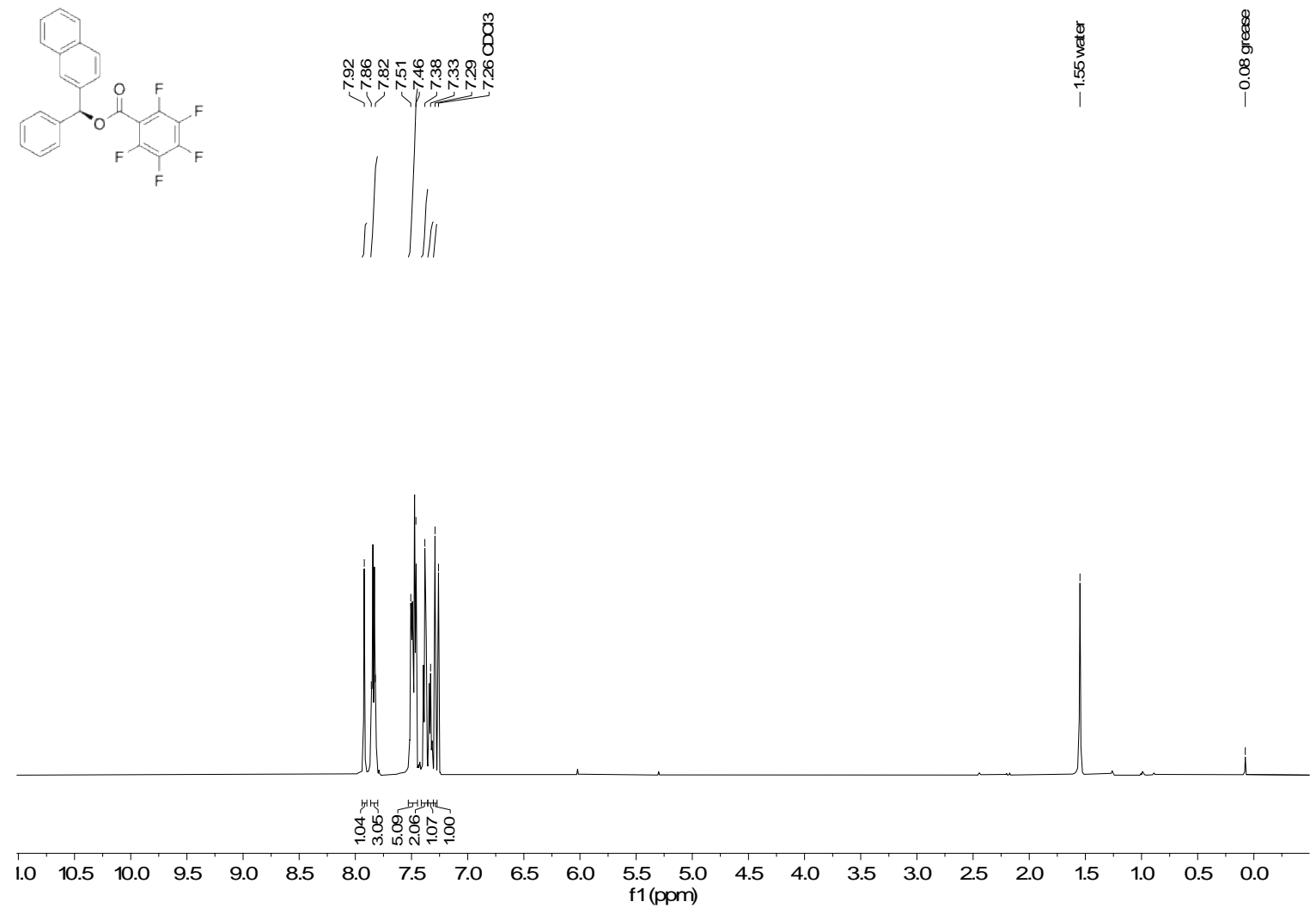

Figure S48: ${ }^{1} \mathrm{H} \mathrm{NMR}\left(\mathrm{CDCl}_{3}, 600 \mathrm{MHz}\right)$ of (S)-(2-naphthyl)(phenyl)methyl pentafluorobenzoate 

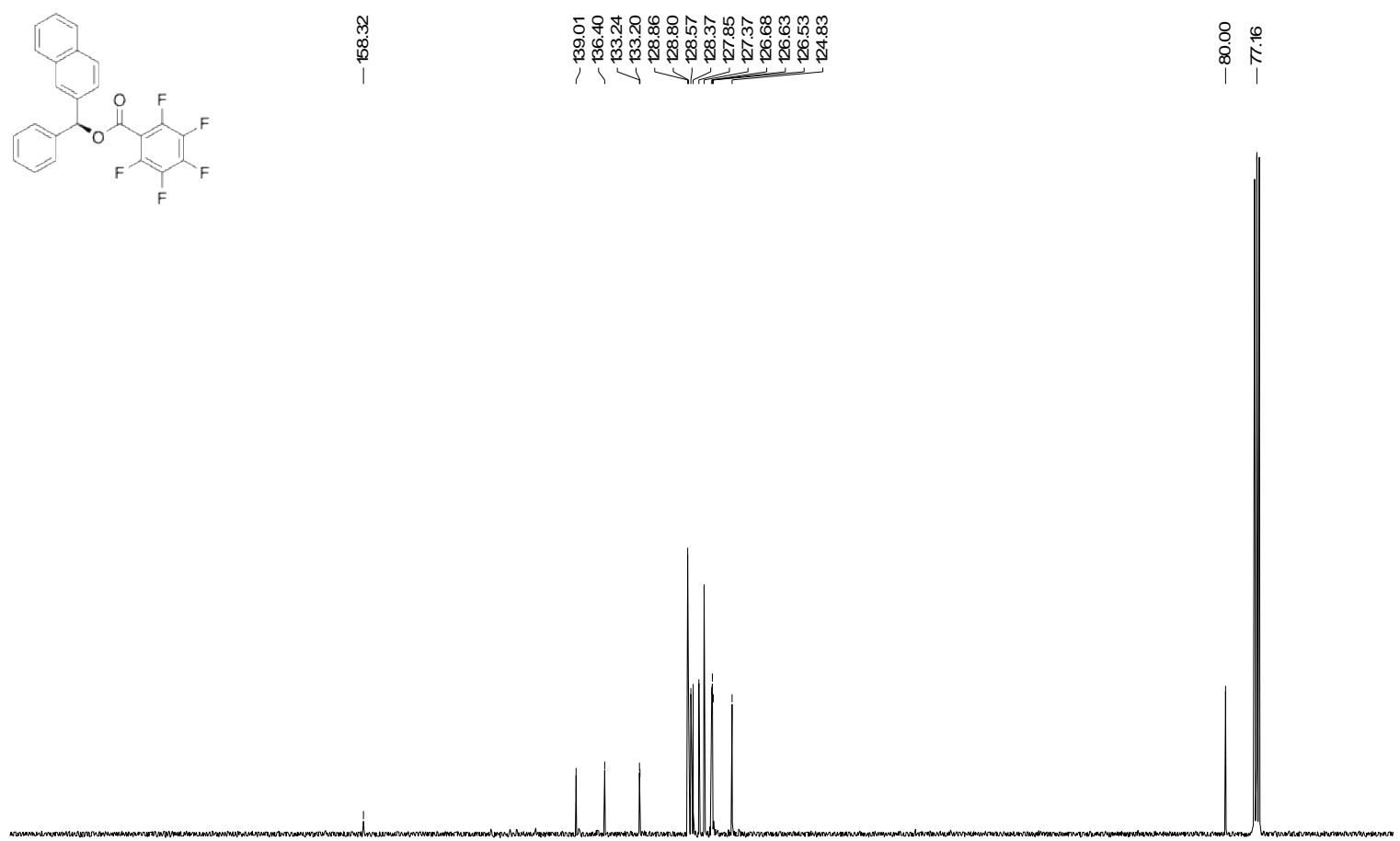

$\begin{array}{lllllllllllllllllllllllllllllllllllllll}90 & 185 & 180 & 175 & 170 & 165 & 160 & 155 & 150 & 145 & 140 & 135 & 130 & 125 & 120 & 115 & 110 & 105 & 100 & 95 & 90 & 85 & 80 & 75 & 70 & 6\end{array}$ Figure S49: ${ }^{13} \mathrm{C}\left\{{ }^{1} \mathrm{H}\right\} \quad \mathrm{NMR} \quad\left(\mathrm{CDCl}_{3}, \quad 151 \mathrm{MHz}\right)$ of (S)-(2-naphthyl)(phenyl)methyl pentafluorobenzoate 


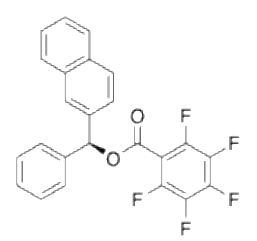

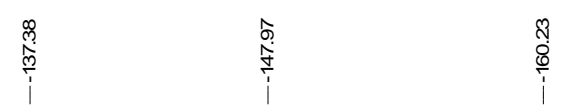

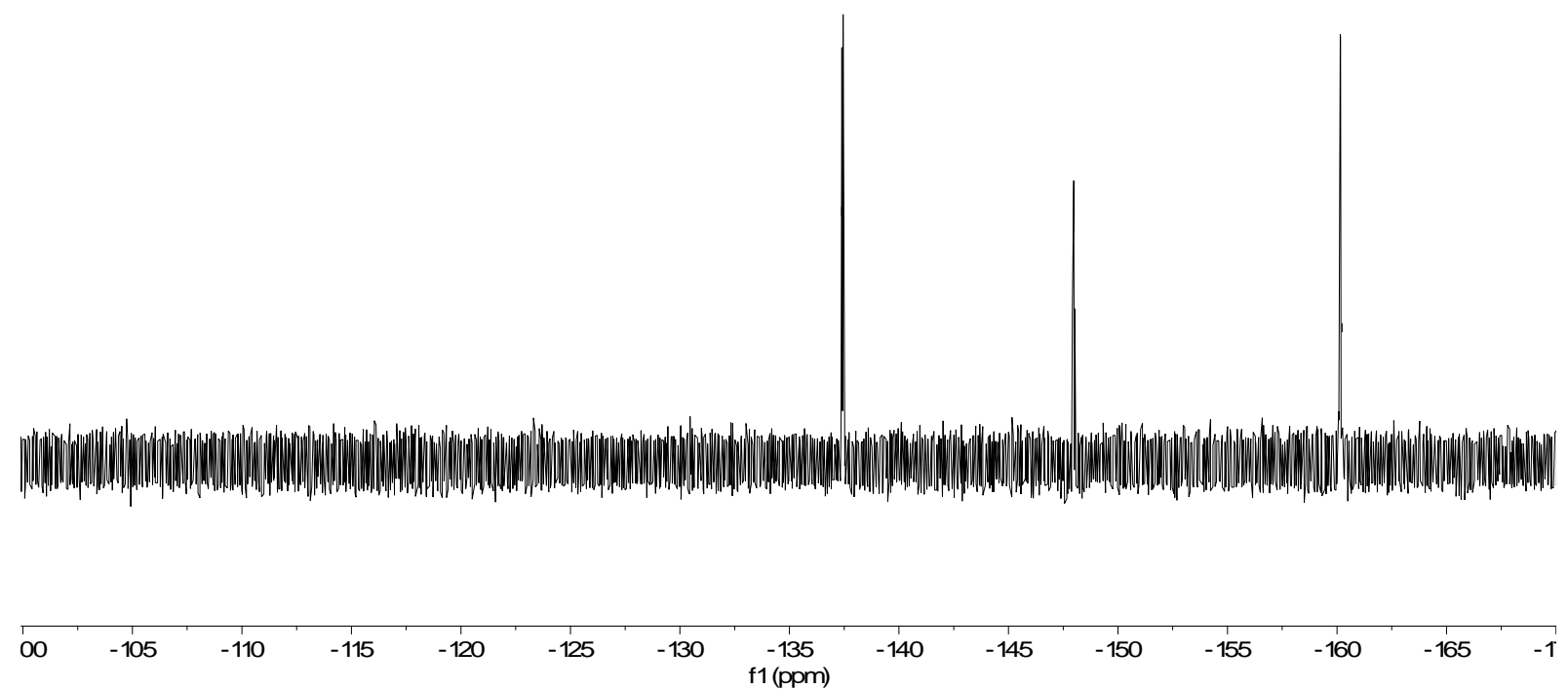

Figure S50: ${ }^{19} \mathrm{~F} \mathrm{NMR}\left(\mathrm{CDCl}_{3}, 376 \mathrm{MHz}\right)$ of $(S)$-(2-naphthyl)(phenyl)methyl pentafluorobenzoate 


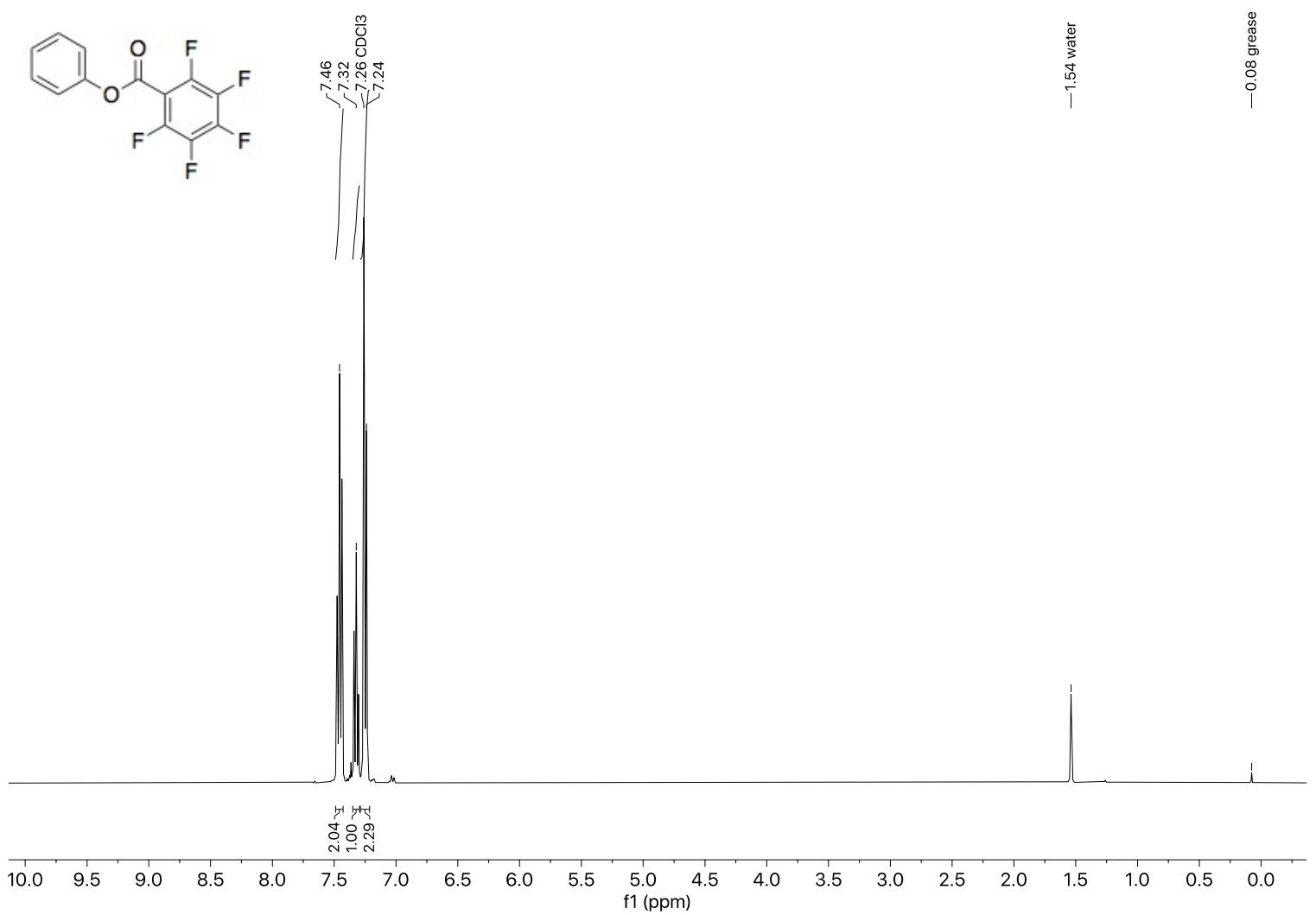

Figure S51: ${ }^{1} \mathrm{H} \mathrm{NMR}\left(\mathrm{CDCl}_{3}, 400 \mathrm{MHz}\right)$ of Phenyl pentafluorobenzoate

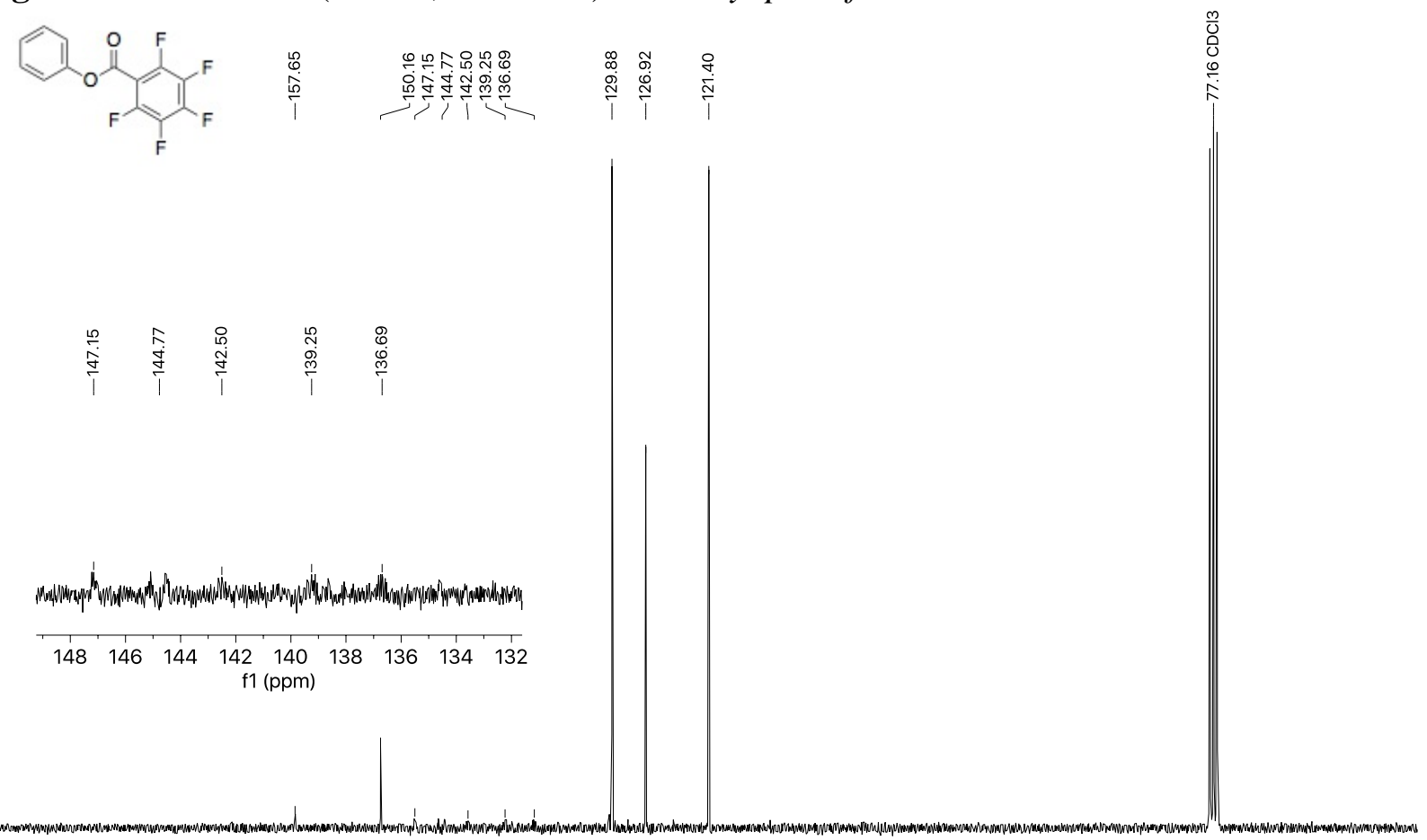

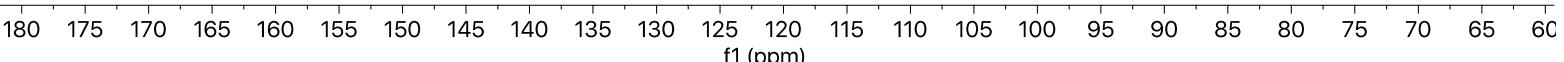

Figure S52: ${ }^{13} \mathrm{C}\left\{{ }^{1} \mathrm{H}\right\} \mathrm{NMR}\left(\mathrm{CDCl}_{3}, 101 \mathrm{MHz}\right)$ of Phenyl pentafluorobenzoate 


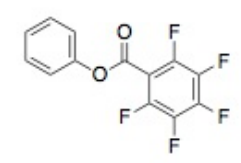

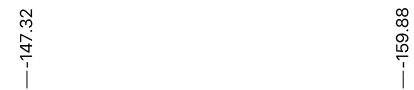

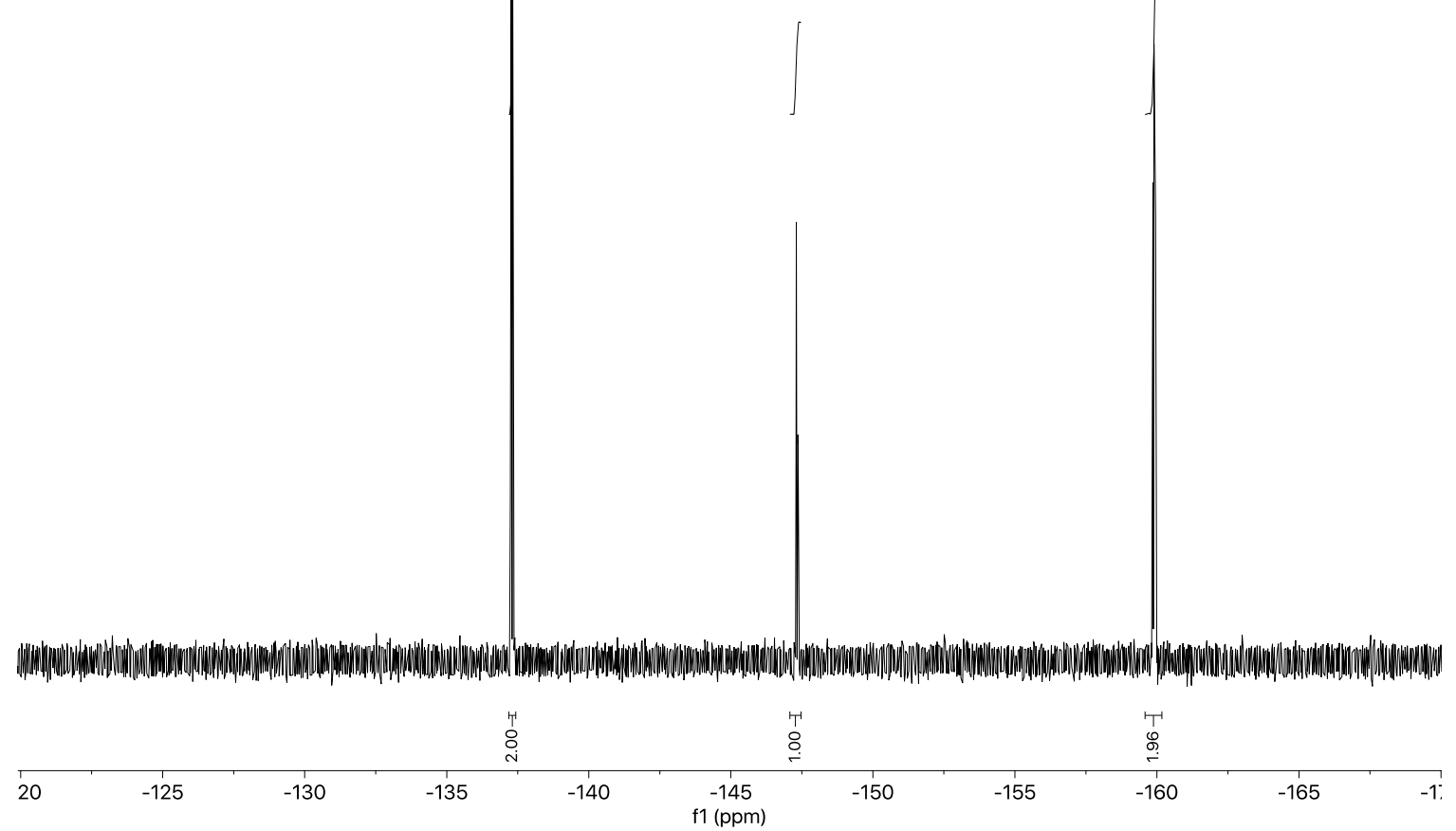

Figure S53: ${ }^{19} \mathrm{~F} \mathrm{NMR}\left(\mathrm{CDCl}_{3}, 376 \mathrm{MHz}\right)$ of Phenyl pentafluorobenzoate 


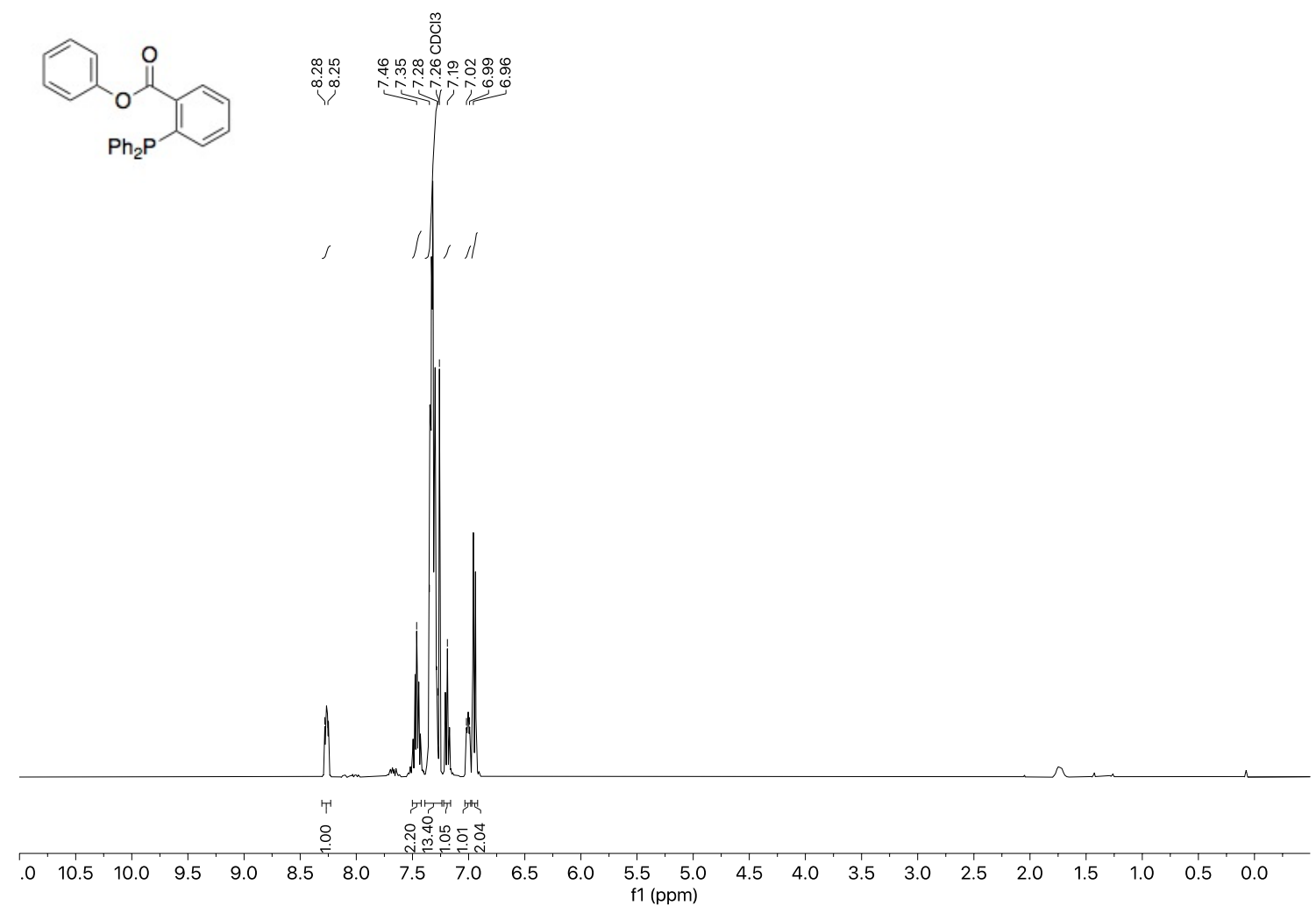

Figure S54: ${ }^{1} \mathrm{H} \mathrm{NMR}\left(\mathrm{CDCl}_{3}, 400 \mathrm{MHz}\right)$ of Phenyl (2-diphenylphosphino)benzoate
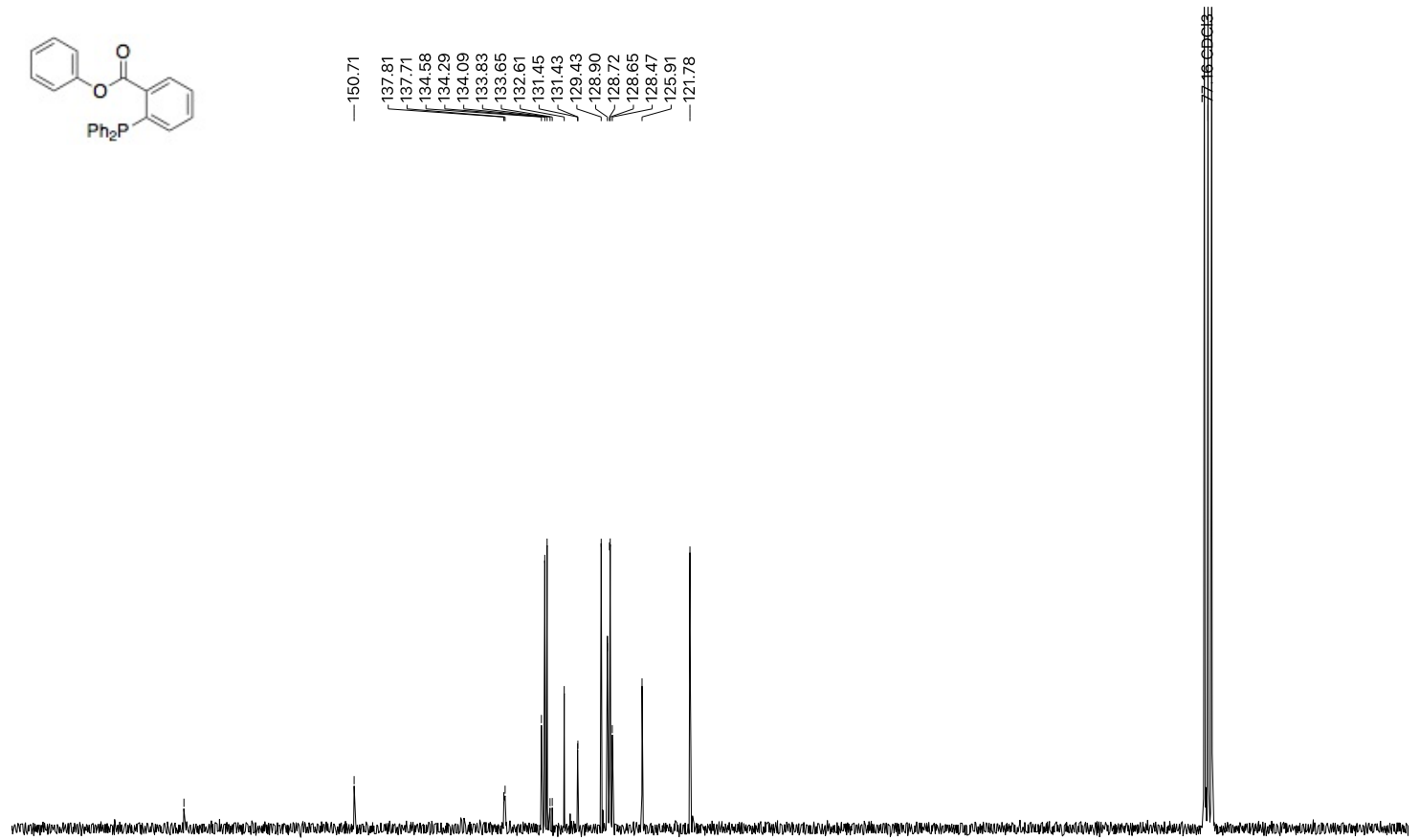

\begin{tabular}{llllllllllllllllllllllllll}
\hline 30 & 175 & 170 & 165 & 160 & 155 & 150 & 145 & 140 & 135 & 130 & 125 & 120 & 115 & 110 & 105 & 100 & 95 & 90 & 85 & 80 & 75 & 70 & 65 & 6
\end{tabular}

Figure S55: ${ }^{13} \mathrm{C}\left\{{ }^{1} \mathrm{H}\right\}$ NMR $\left(\mathrm{CDCl}_{3}, 101 \mathrm{MHz}\right)$ of Phenyl (2-diphenylphosphino)benzoate 

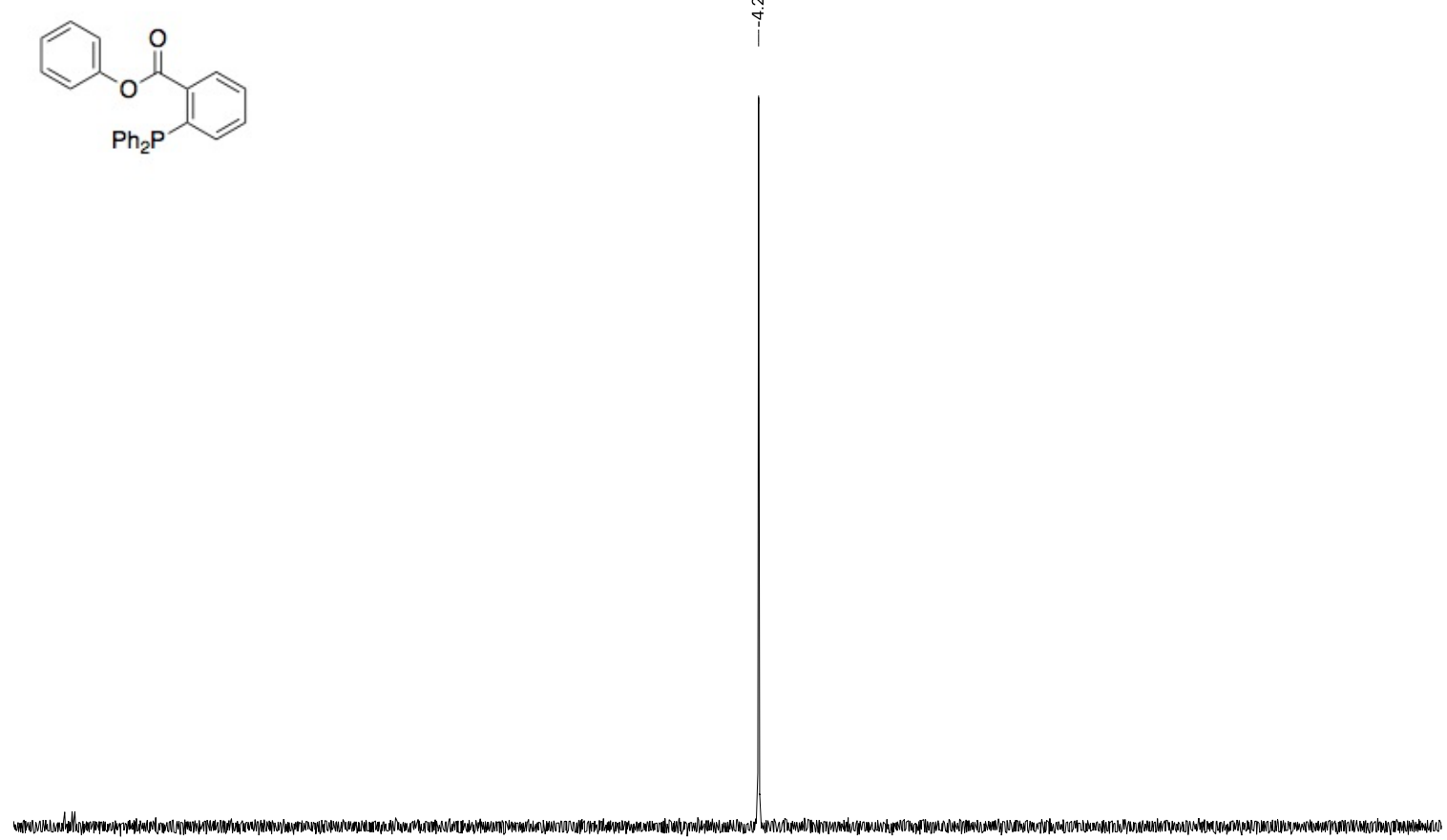

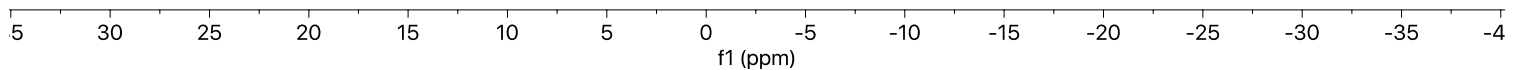

Figure S56: ${ }^{31} \mathrm{P}\left\{{ }^{1} \mathrm{H}\right\} \mathrm{NMR}\left(\mathrm{CDCl}_{3}, 121 \mathrm{MHz}\right)$ of Phenyl (2-diphenylphosphino)benzoate 
XI(B). NMR spectra of cross-coupled products.
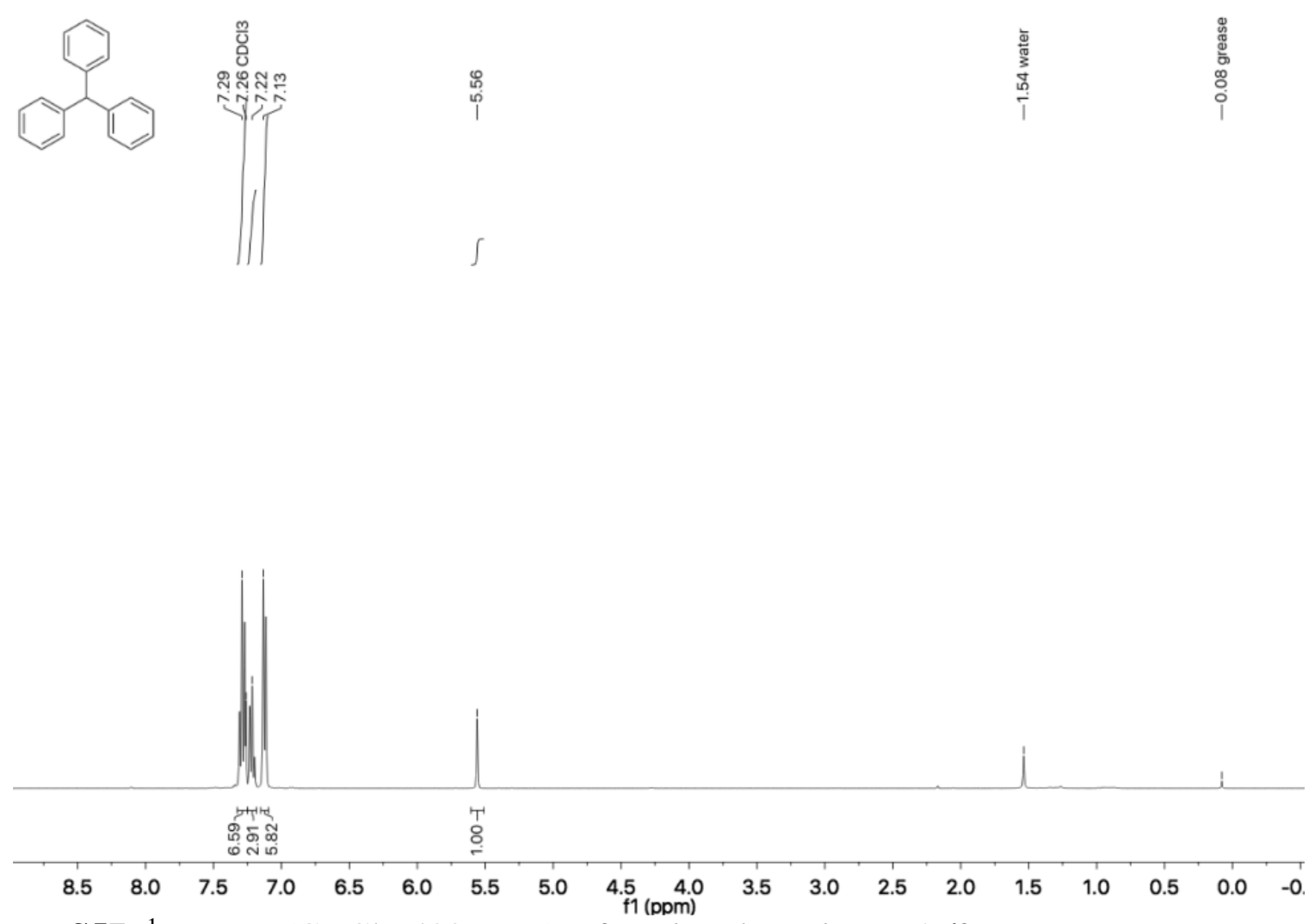

Figure S57: ${ }^{1} \mathrm{H} \mathrm{NMR}\left(\mathrm{CDCl}_{3}, 400 \mathrm{MHz}\right)$ of triphenyl) methane $(\boldsymbol{6 a} / 8 \boldsymbol{a})$

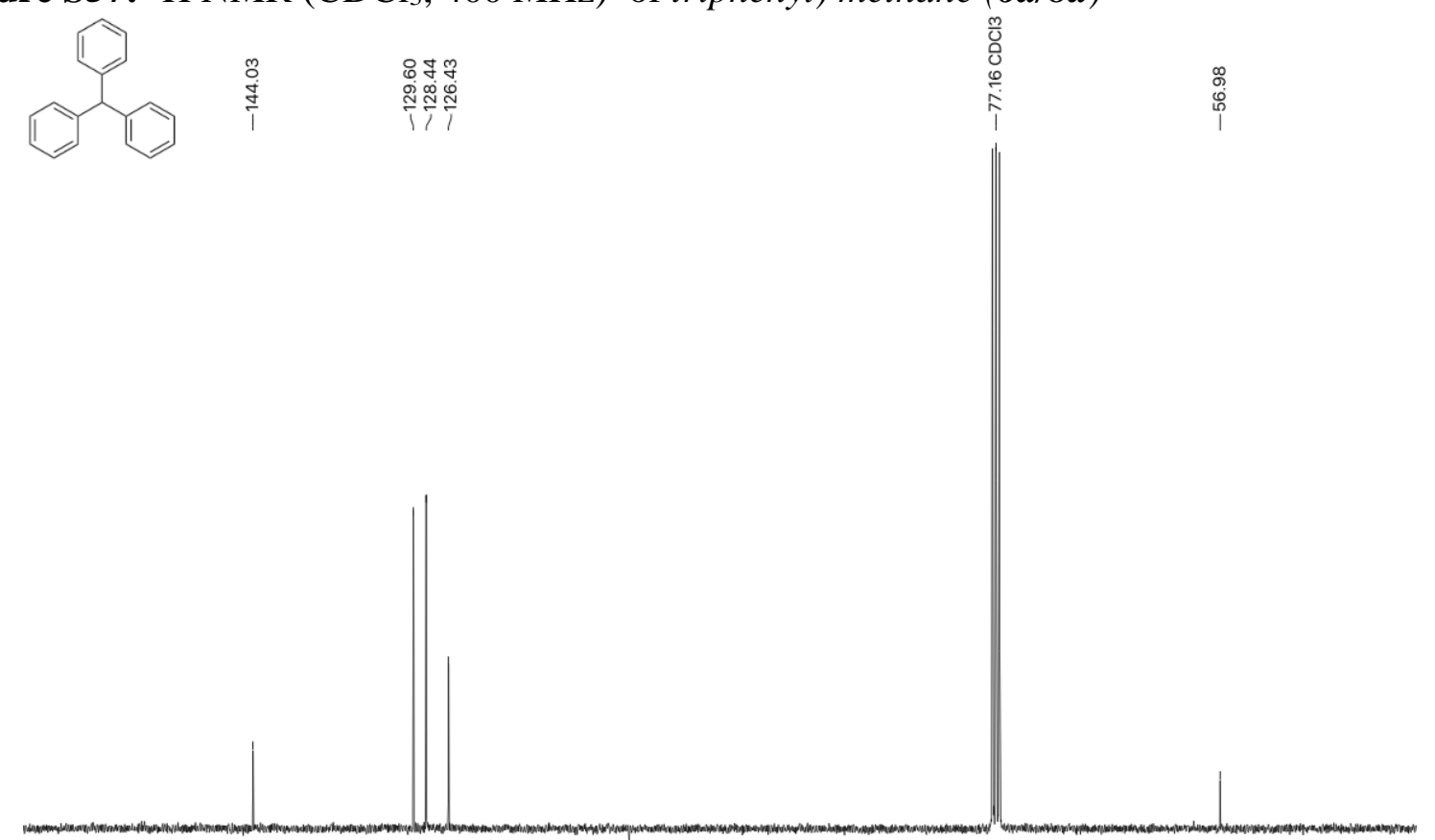

$\begin{array}{llllllllllllllllllllllllllll}160 & 155 & 150 & 145 & 140 & 135 & 130 & 125 & 120 & 115 & 110 & \underset{f 1}{105}(\mathrm{ppm}) & 95 & 90 & 85 & 80 & 75 & 70 & 65 & 60 & 55 & 50 & 45 & 4 \mathrm{C}\end{array}$

Figure S58: ${ }^{13} \mathrm{C}\left\{{ }^{1} \mathrm{H}\right\} \mathrm{NMR}\left(\mathrm{CDCl}_{3}, 101 \mathrm{MHz}\right)$ of triphenyl) methane $(\boldsymbol{6 a} / \mathbf{8 a})$ 


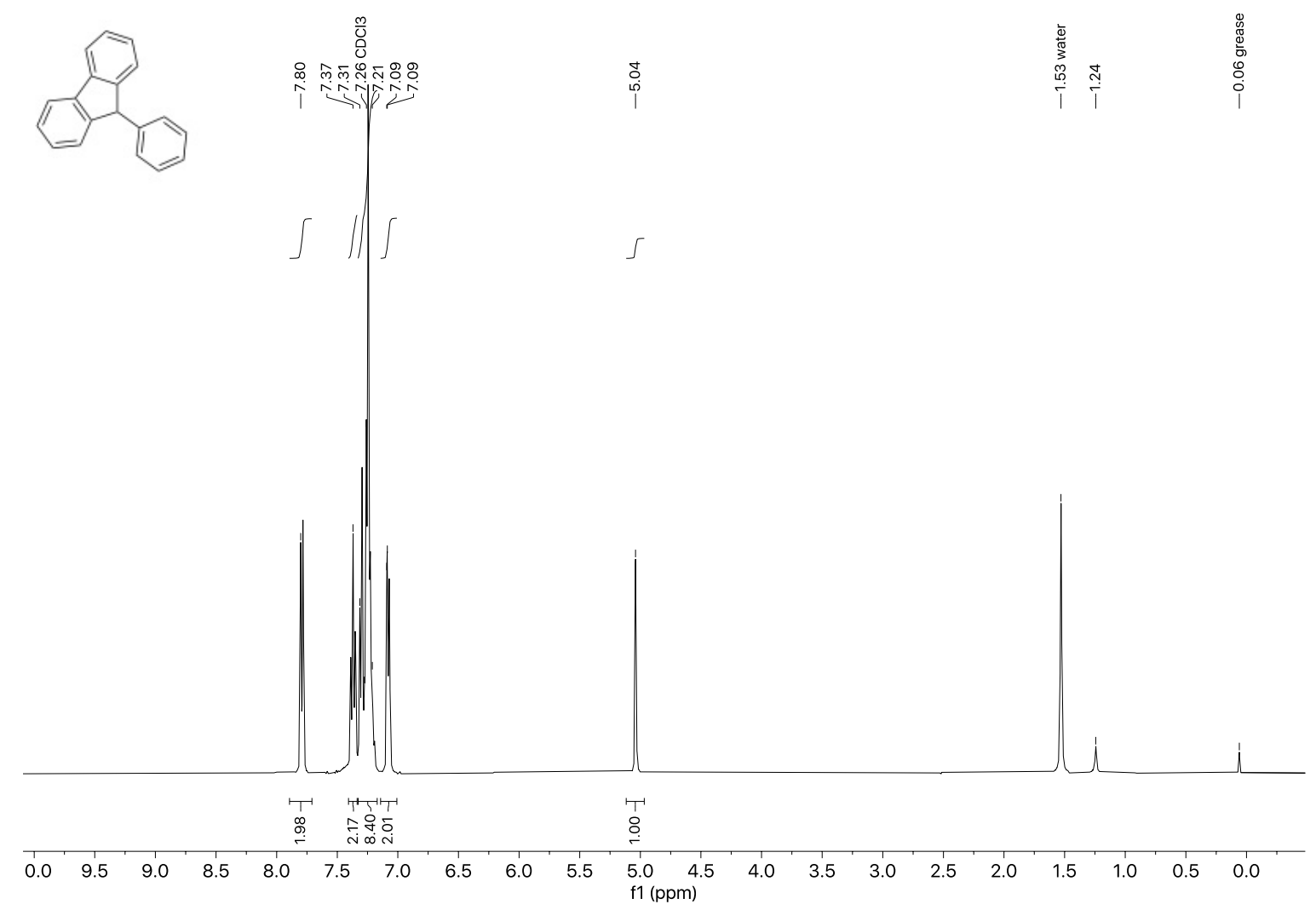

Figure S59: ${ }^{1} \mathrm{H} \mathrm{NMR}\left(\mathrm{CDCl}_{3}, 400 \mathrm{MHz}\right)$ of 9-phenyl-9H-fluorene (6b)
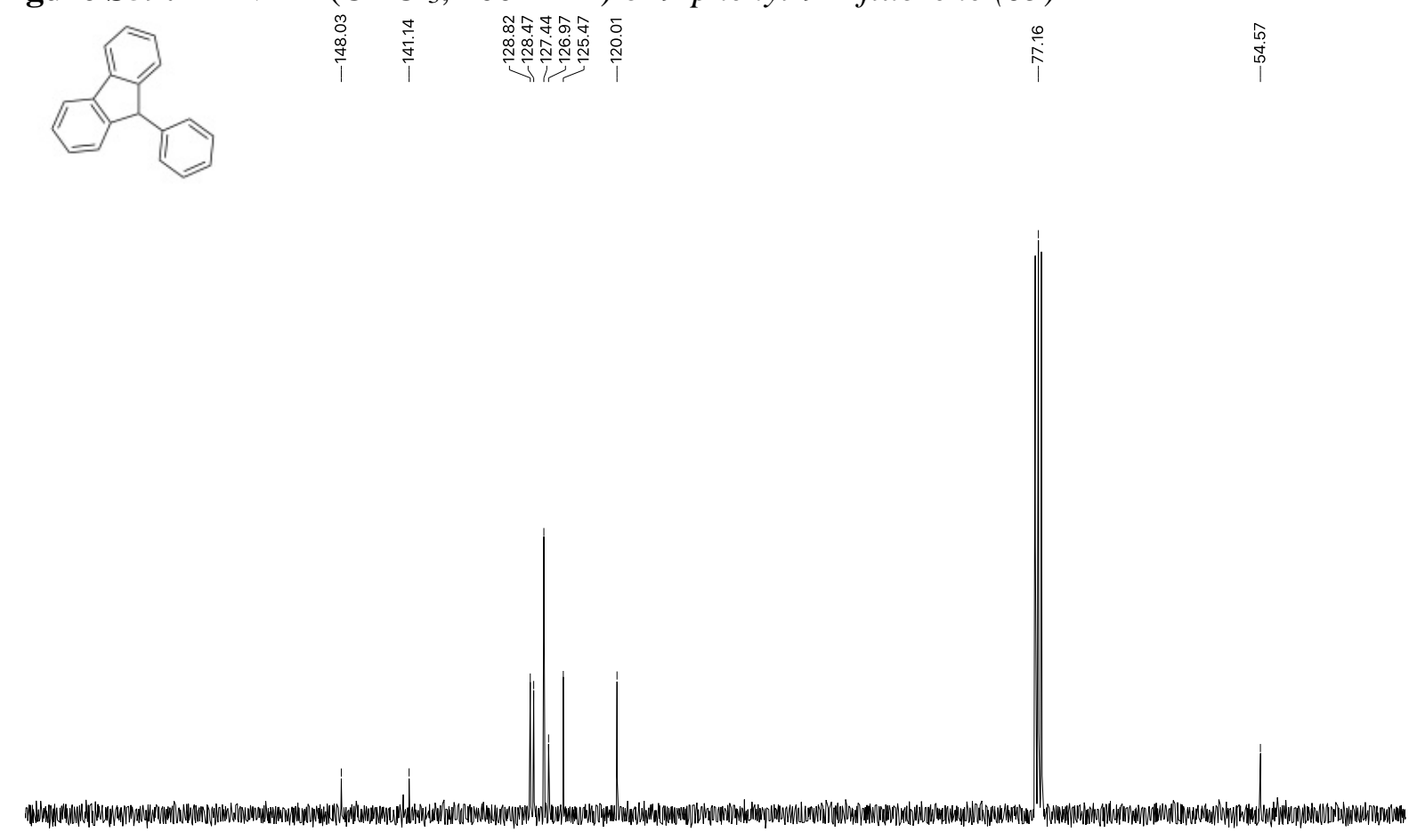

$\begin{array}{llllllllllllllllllllllllllllll}30 & 175 & 170 & 165 & 160 & 155 & 150 & 145 & 140 & 135 & 130 & 125 & 120 & 115 & 110 & 105 & 100 & 95 & 90 & 85 & 80 & 75 & 70 & 65 & 60 & 55 & 50 & 45 & 41\end{array}$ Figure S60: ${ }^{13} \mathrm{C}\left\{{ }^{1} \mathrm{H}\right\} \mathrm{NMR}\left(\mathrm{CDCl}_{3}, 151 \mathrm{MHz}\right)$ of 9-phenyl-9H-fluorene $(\boldsymbol{6} \boldsymbol{b})$ 


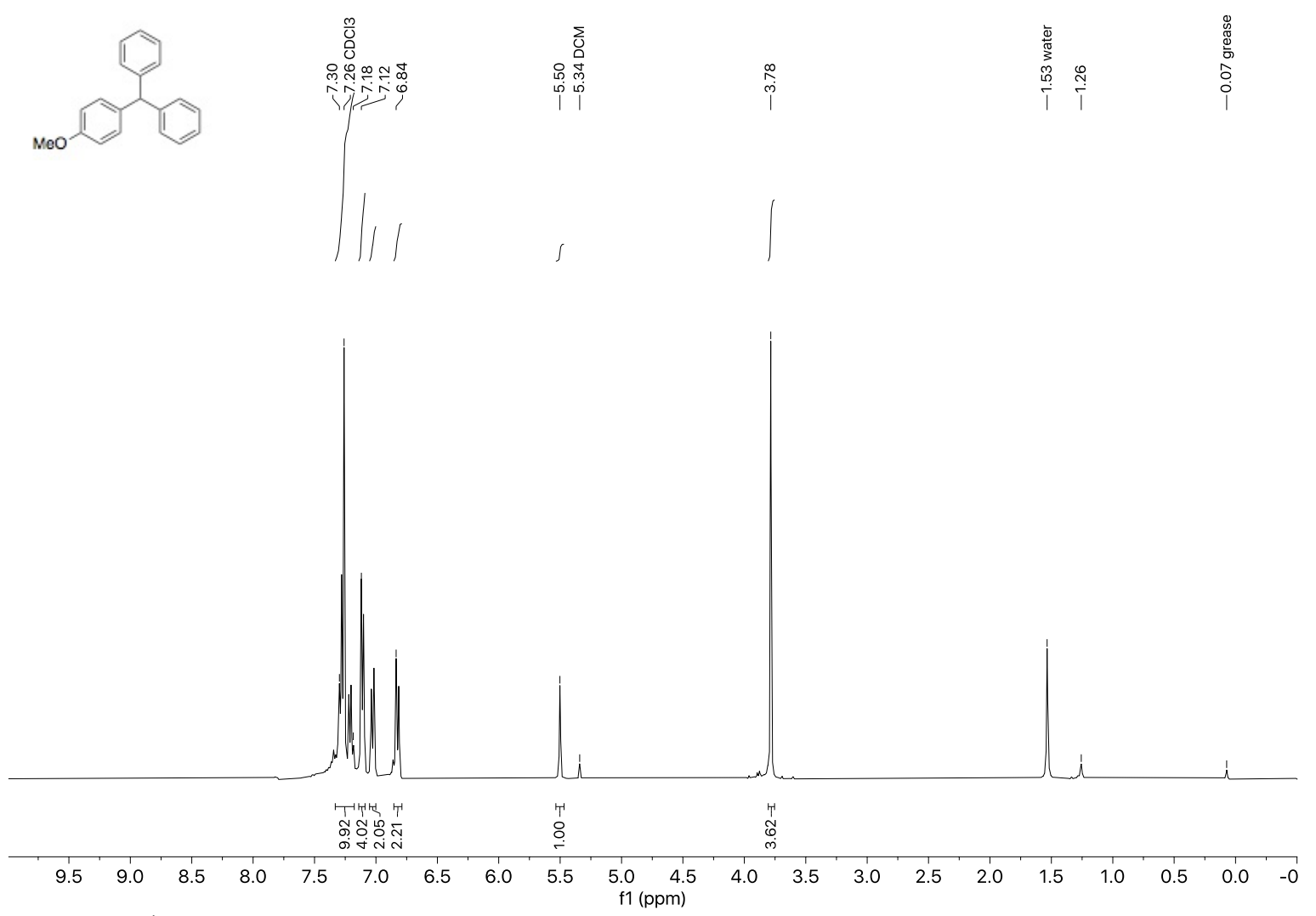

Figure S61: ${ }^{1} \mathrm{H} \mathrm{NMR}\left(\mathrm{CDCl}_{3}, 400 \mathrm{MHz}\right)$ of (4-methoxyphenyl)(diphenyl) methane (6c)

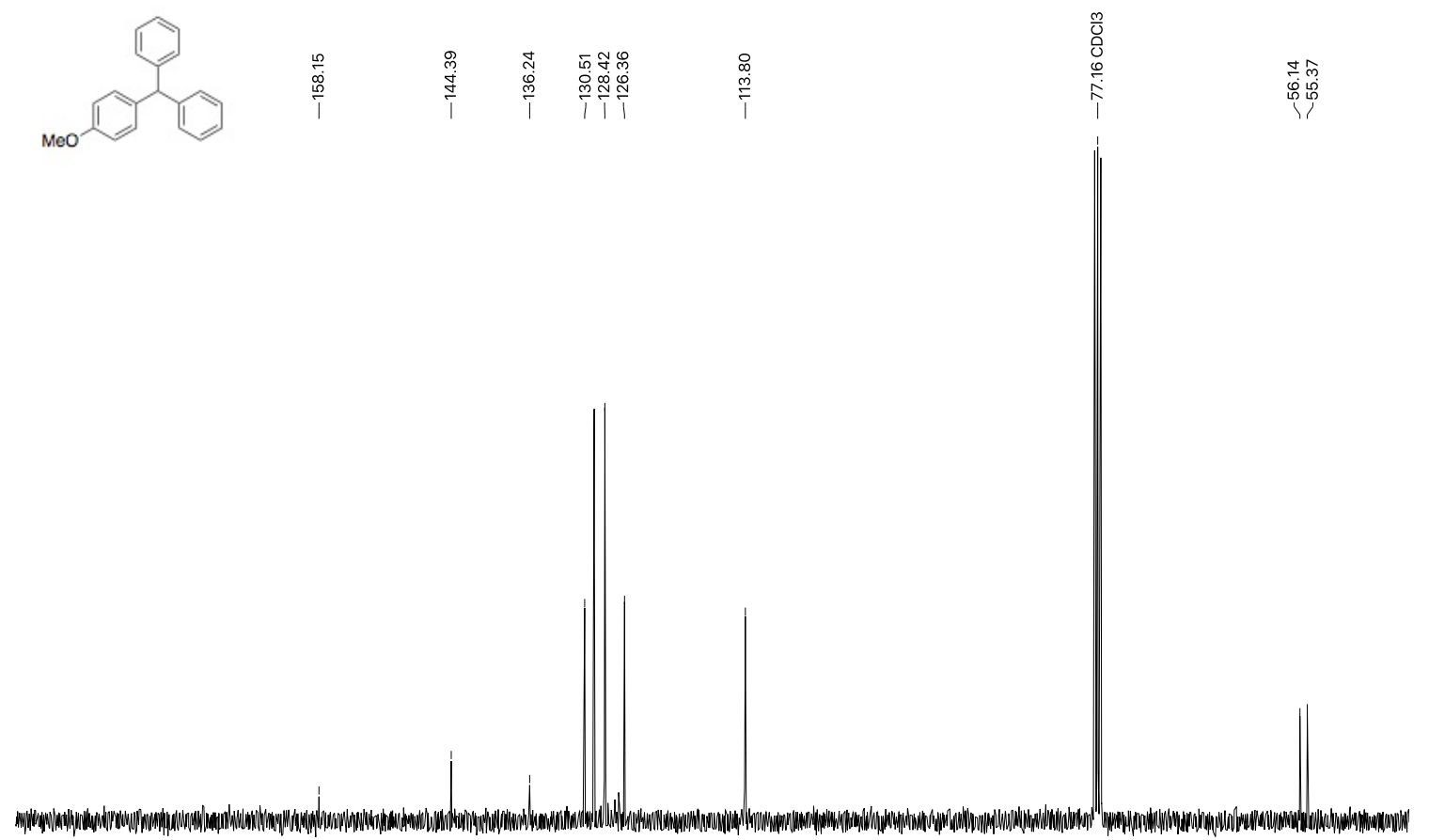

$\begin{array}{llllllllllllllllllllllllllllllllllllllll}185 & 180 & 175 & 170 & 165 & 160 & 155 & 150 & 145 & 140 & 135 & 130 & 125 & 120 & 115 & 110 & 105 & 100 & 95 & 90 & 85 & 80 & 75 & 70 & 65 & 60 & 55 & 50 & 4\end{array}$

Figure S62: ${ }^{13} \mathrm{C}\left\{{ }^{1} \mathrm{H}\right\} \mathrm{NMR}\left(\mathrm{CDCl}_{3}, 101 \mathrm{MHz}\right)$ of (4-methoxyphenyl)(diphenyl) methane (6c) 

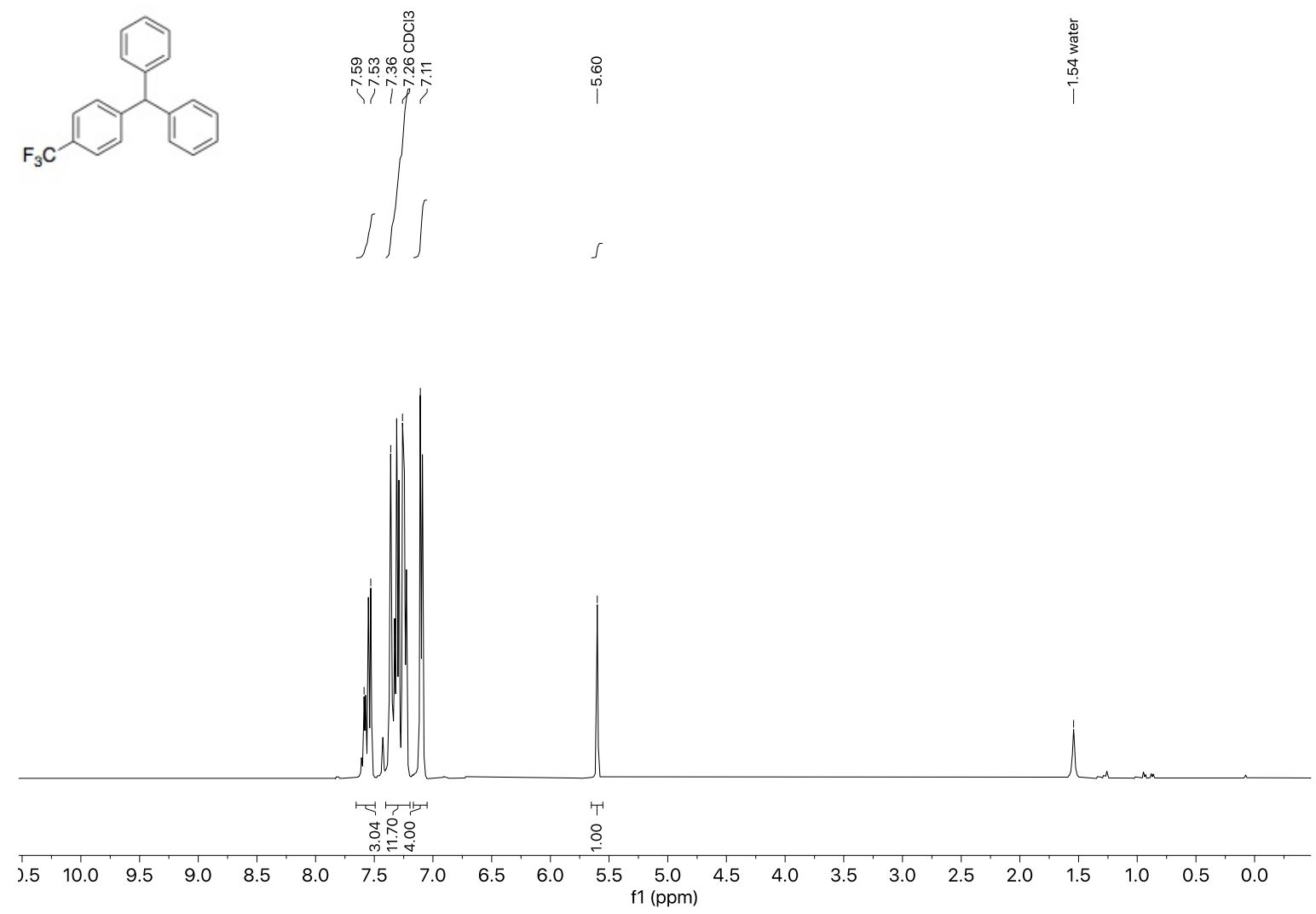

Figure S63: ${ }^{1} \mathrm{H} \mathrm{NMR}\left(\mathrm{CDCl}_{3}, 400 \mathrm{MHz}\right)$ of (4-trifluoromethylphenyl)(diphenyl) methane (6d) 


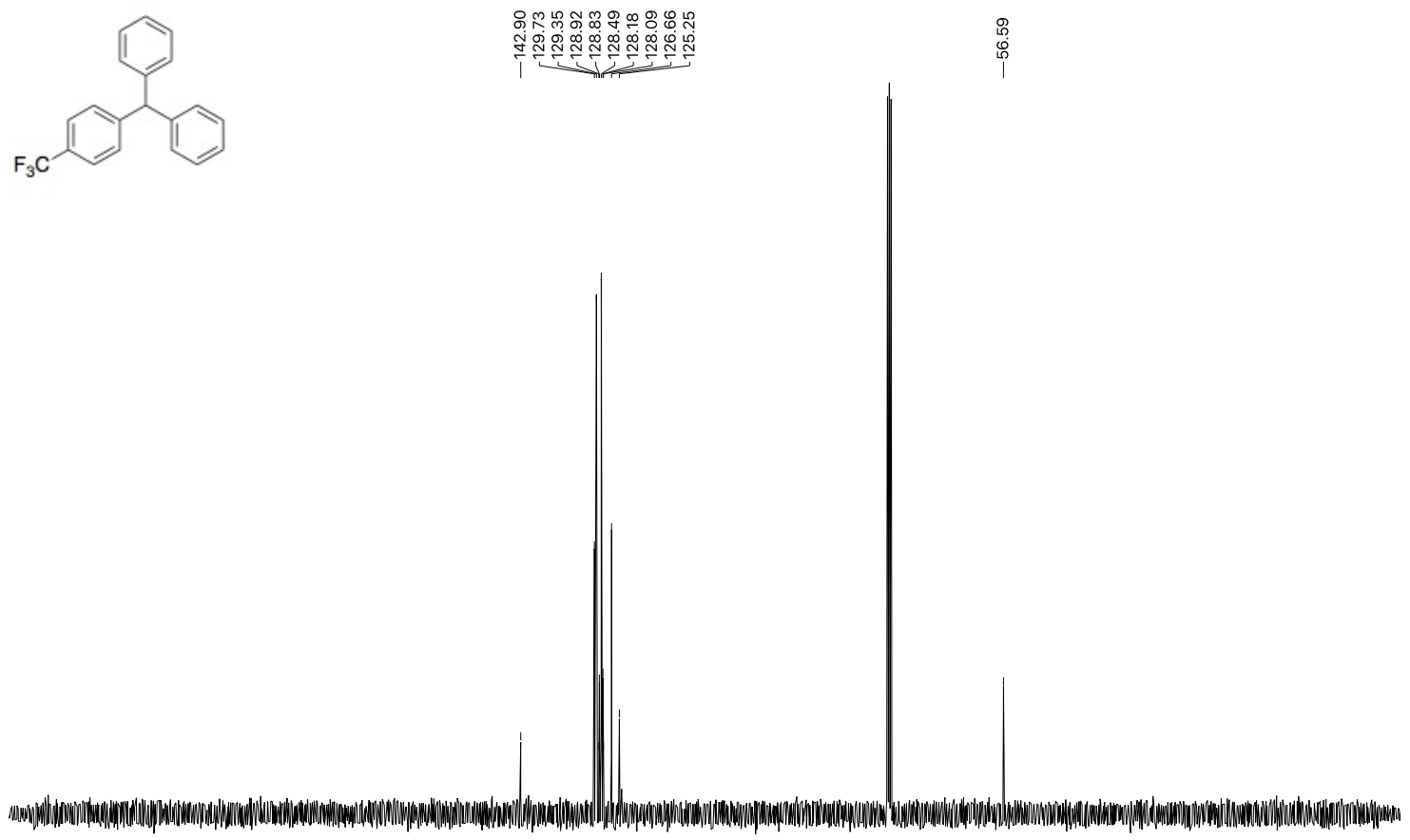

$\begin{array}{llllllllllllllllllllllllllll}230 & 220 & 210 & 200 & 190 & 180 & 170 & 160 & 150 & 140 & 130 & 120 & 110 & 100 & 90 & 80 & 70 & 60 & 50 & 40 & 30 & 20 & 10 & 0 & -10\end{array}$

Figure S64: ${ }^{13} \mathrm{C}\left\{{ }^{1} \mathrm{H}\right\} \mathrm{NMR}\left(\mathrm{CDCl}_{3}, 101 \mathrm{MHz}\right)$ of (4-trifluoromethylphenyl)(diphenyl) methane $(\boldsymbol{6 d})$ 

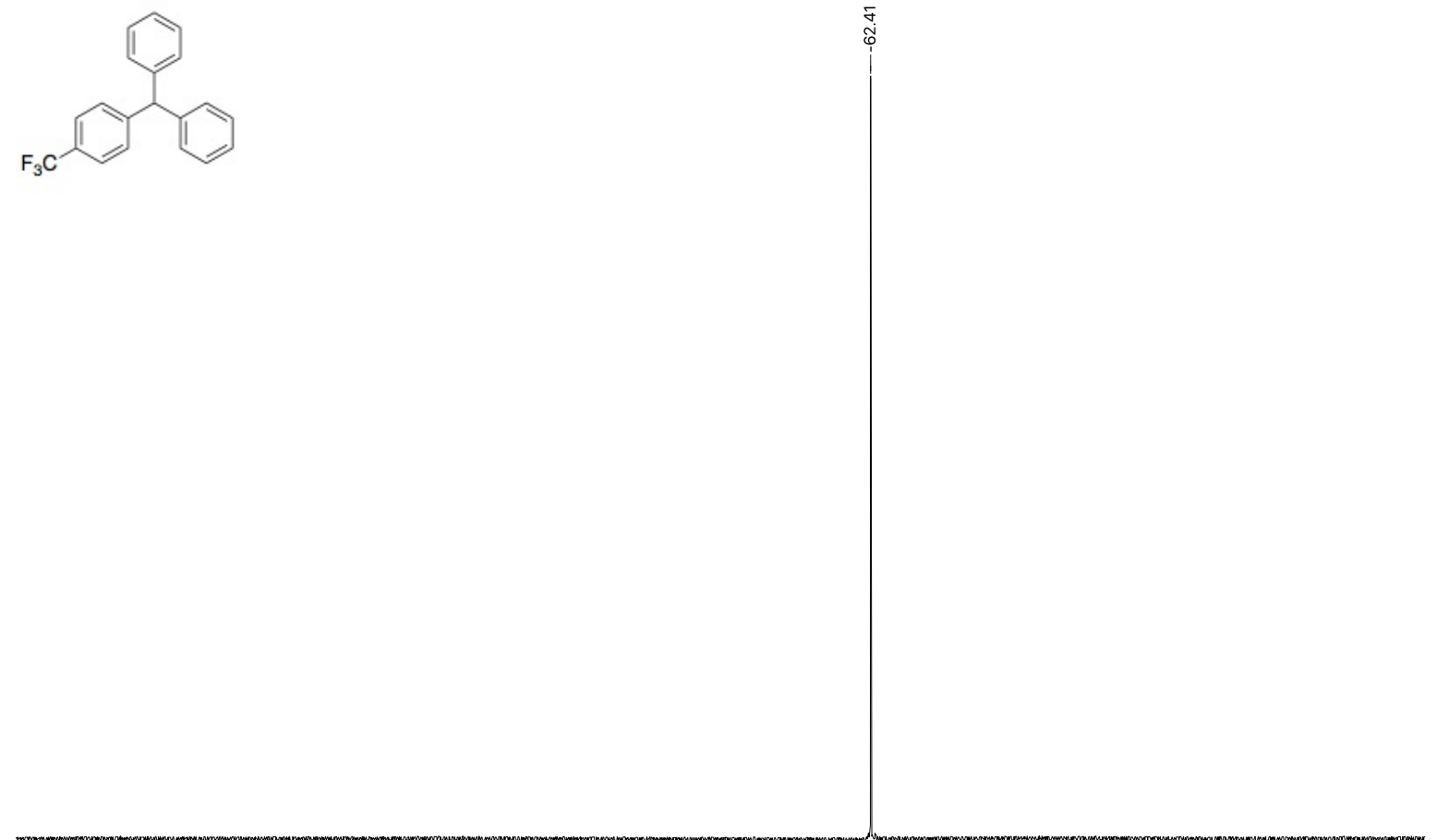

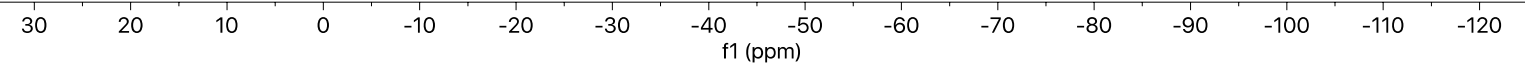

Figure S65: ${ }^{13} \mathrm{C}\left\{{ }^{1} \mathrm{H}\right\} \mathrm{NMR}\left(\mathrm{CDCl}_{3}, 101 \mathrm{MHz}\right)$ of (4-trifluoromethylphenyl)(diphenyl) methane (6d) 
<smiles>N#Cc1ccc(C(c2ccccc2)c2ccc(C#N)cc2)cc1</smiles>

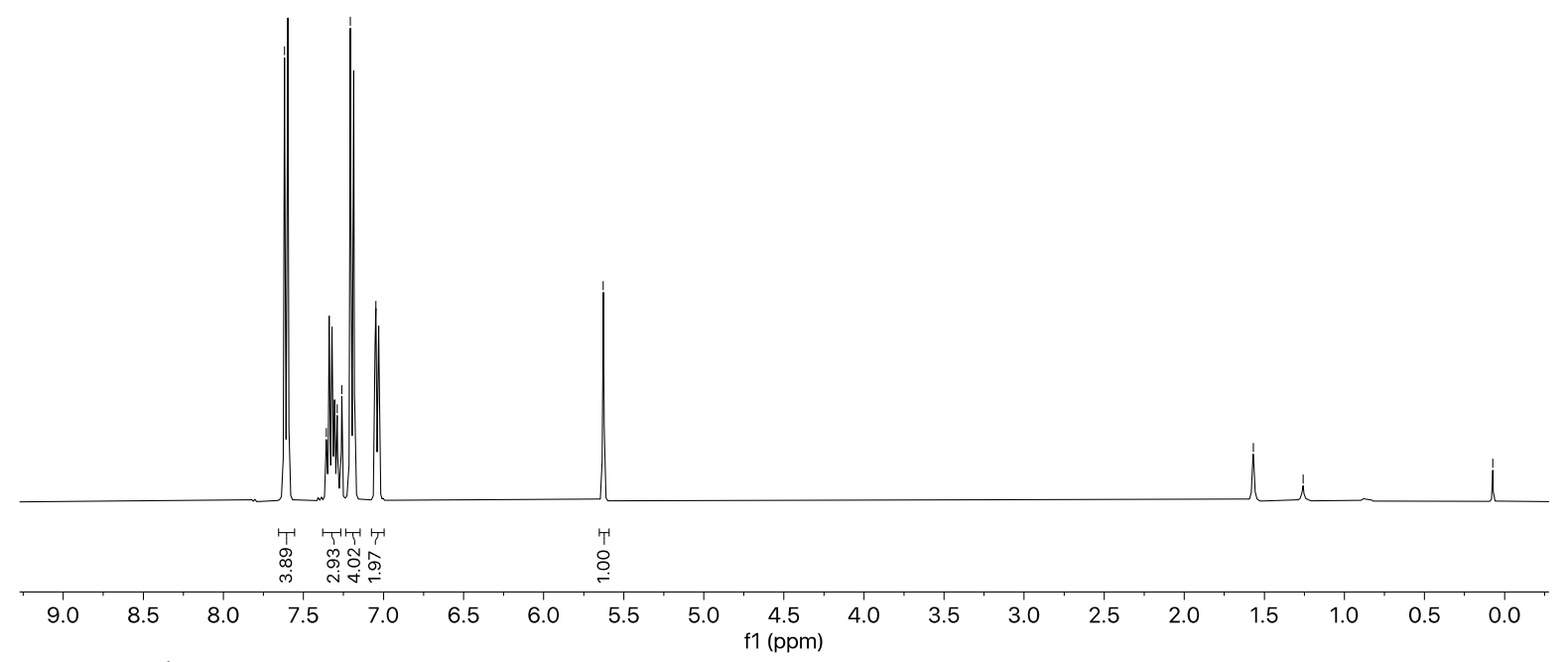

Figure S66: ${ }^{1} \mathrm{H} \mathrm{NMR}\left(\mathrm{CDCl}_{3}, 400 \mathrm{MHz}\right)$ of bis(4-cyanophenyl)(phenyl) methane (6e)

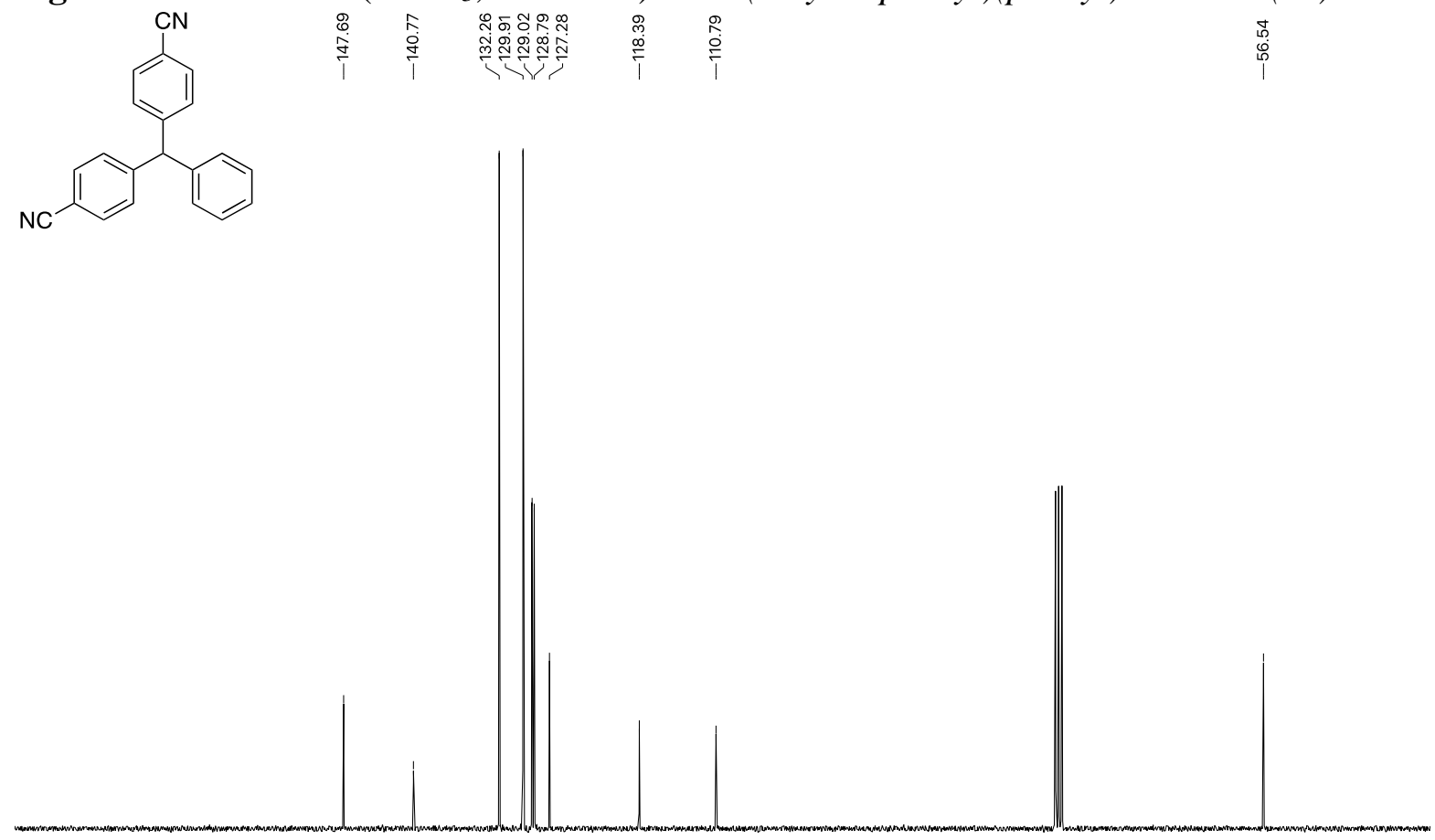

$\begin{array}{llllllllllllllllllllllllllllllllll}30 & 175 & 170 & 165 & 160 & 155 & 150 & 145 & 140 & 135 & 130 & 125 & 120 & 115 & 110 & 105 & 100 & 95 & 90 & 85 & 80 & 75 & 70 & 65 & 60 & 55 & 50 & 45\end{array}$ Figure S67: ${ }^{13} \mathrm{C}\left\{{ }^{1} \mathrm{H}\right\} \mathrm{NMR}\left(\mathrm{CDCl}_{3}, 101 \mathrm{MHz}\right)$ of bis(4-cyanophenyl)(phenyl) methane (6e) 


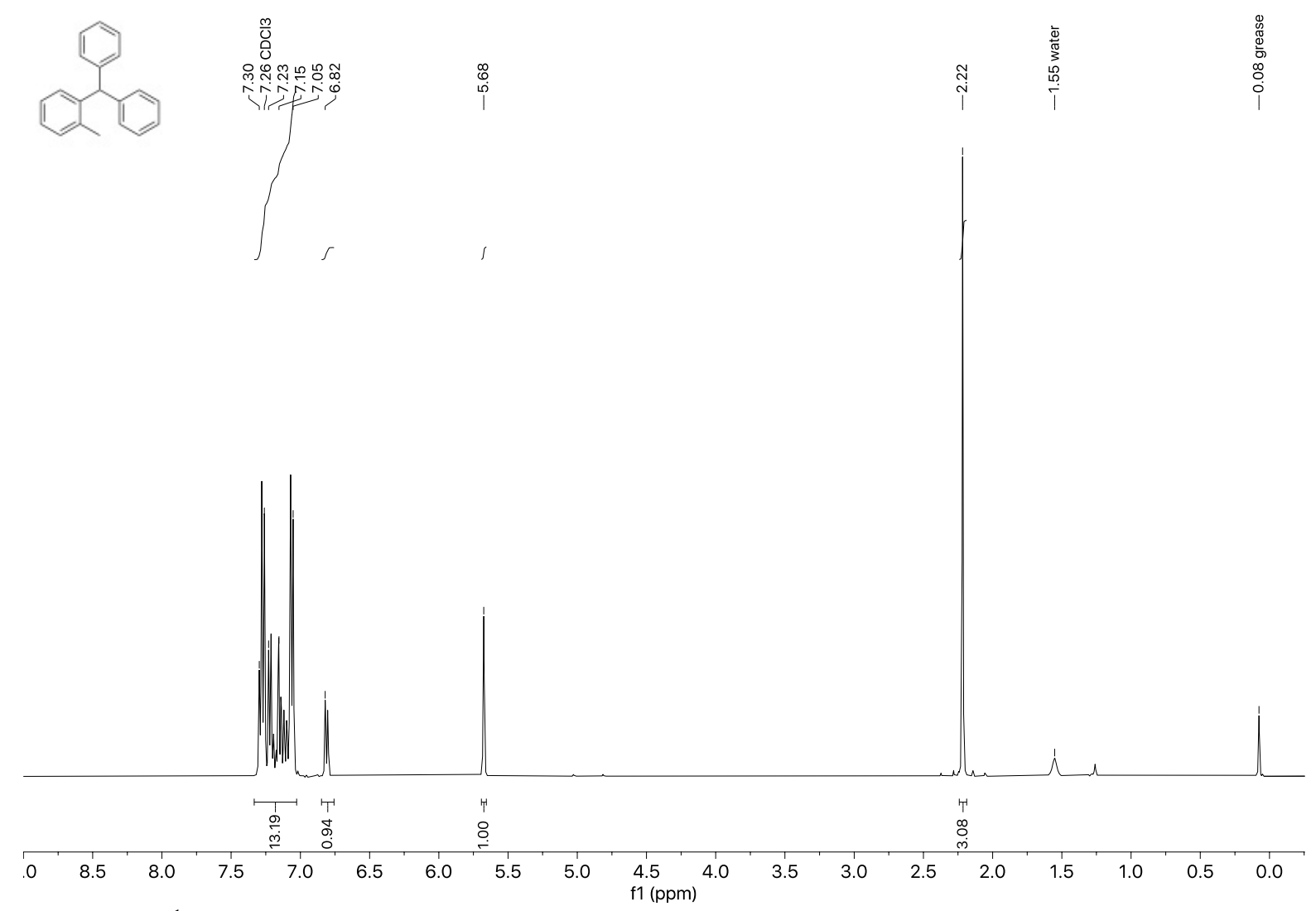

Figure S68: ${ }^{1} \mathrm{H} \mathrm{NMR}\left(\mathrm{CDCl}_{3}, 500 \mathrm{MHz}\right)$ of (2-methylphenyl)(diphenyl) methane (6f)

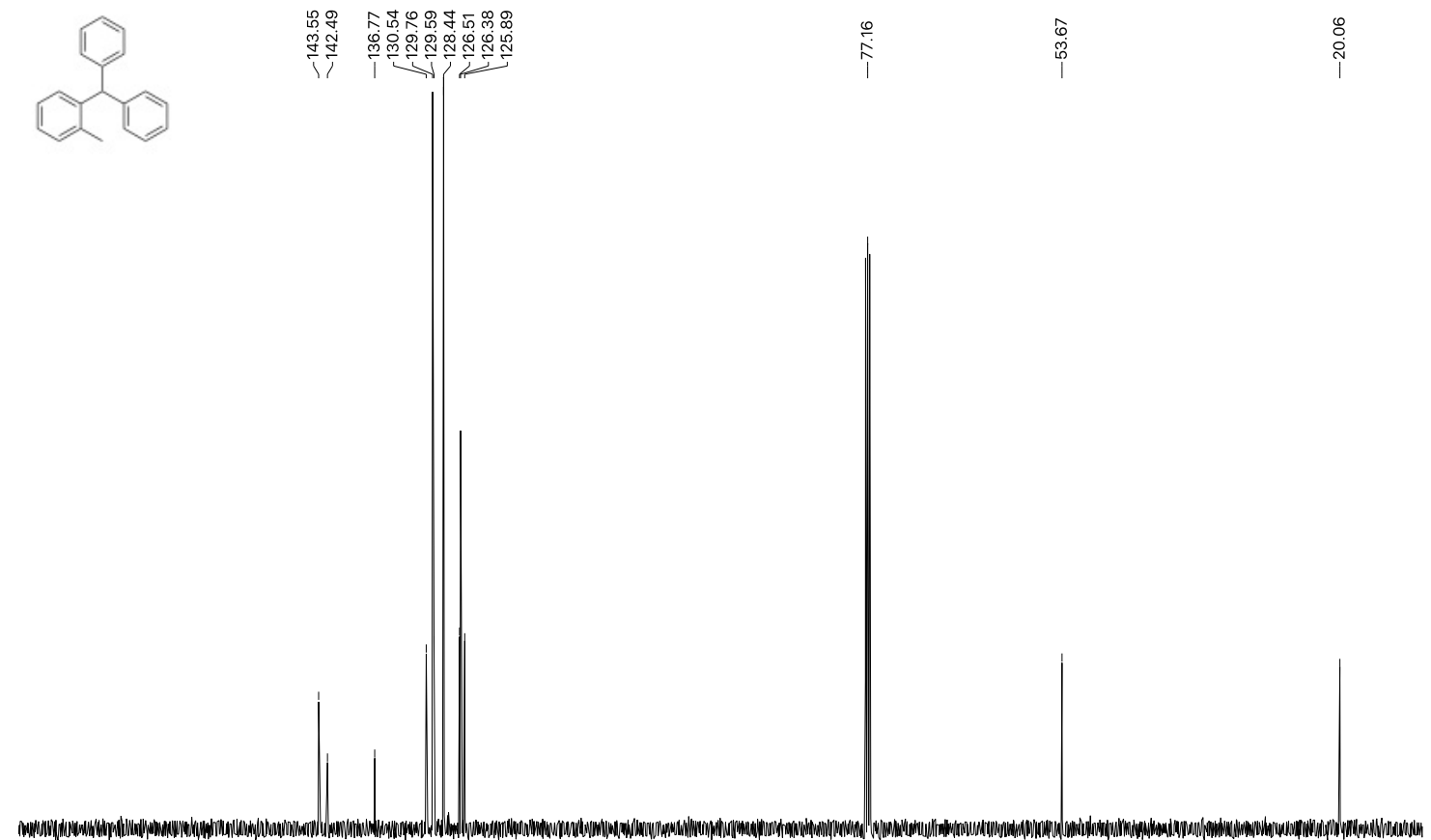

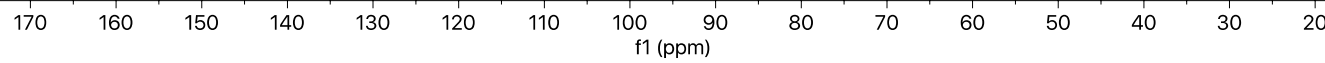

Figure S69: ${ }^{13} \mathrm{C}\left\{{ }^{1} \mathrm{H}\right\} \mathrm{NMR}\left(\mathrm{CDCl}_{3}, 126 \mathrm{MHz}\right)$ of (2-methylphenyl)(diphenyl) methane (6f) 

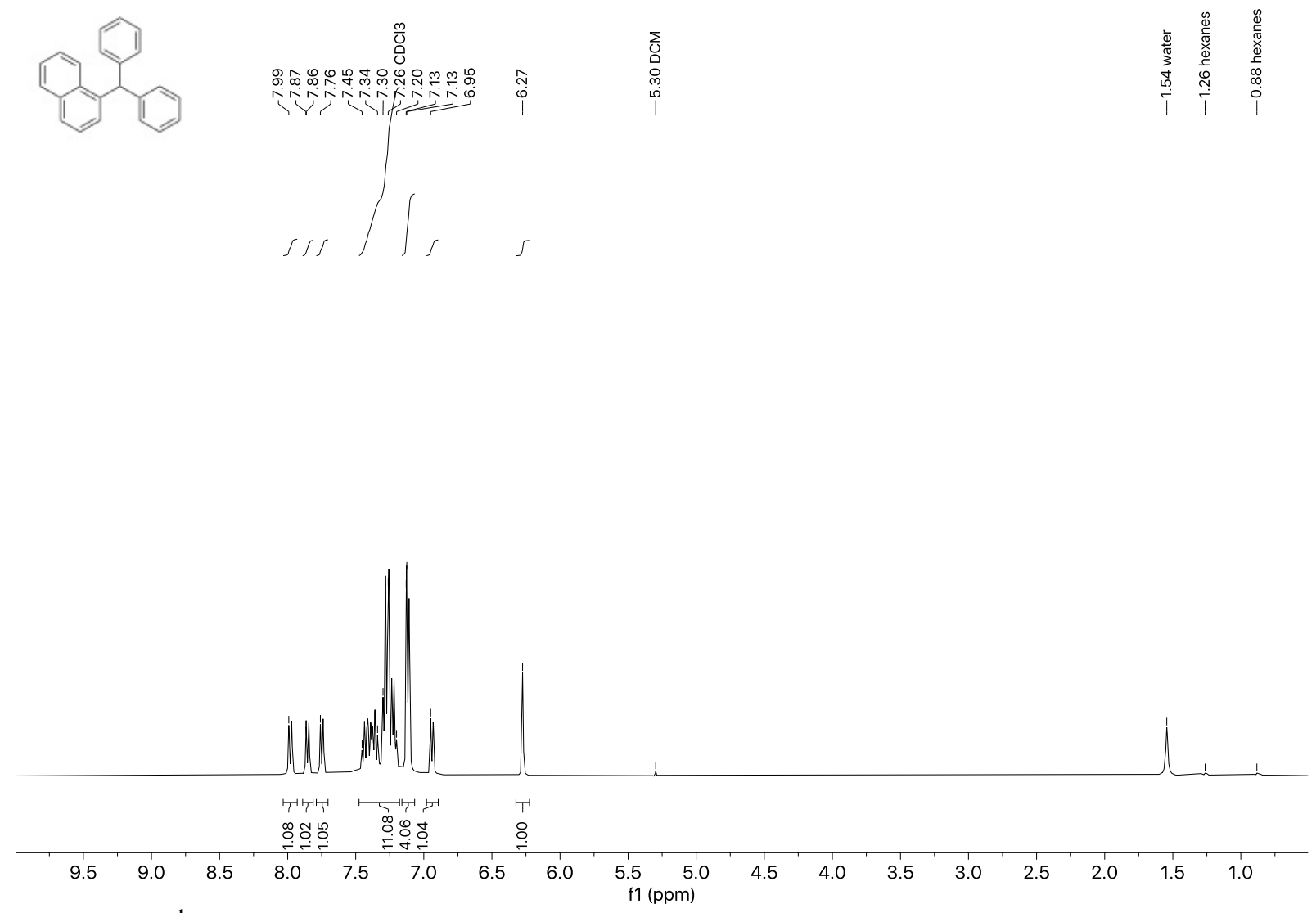

Figure S70: ${ }^{1} \mathrm{H} \mathrm{NMR}\left(\mathrm{CDCl}_{3}, 400 \mathrm{MHz}\right)$ of (1-naphthyl)(phenyl) methane $(\mathbf{6 g})$

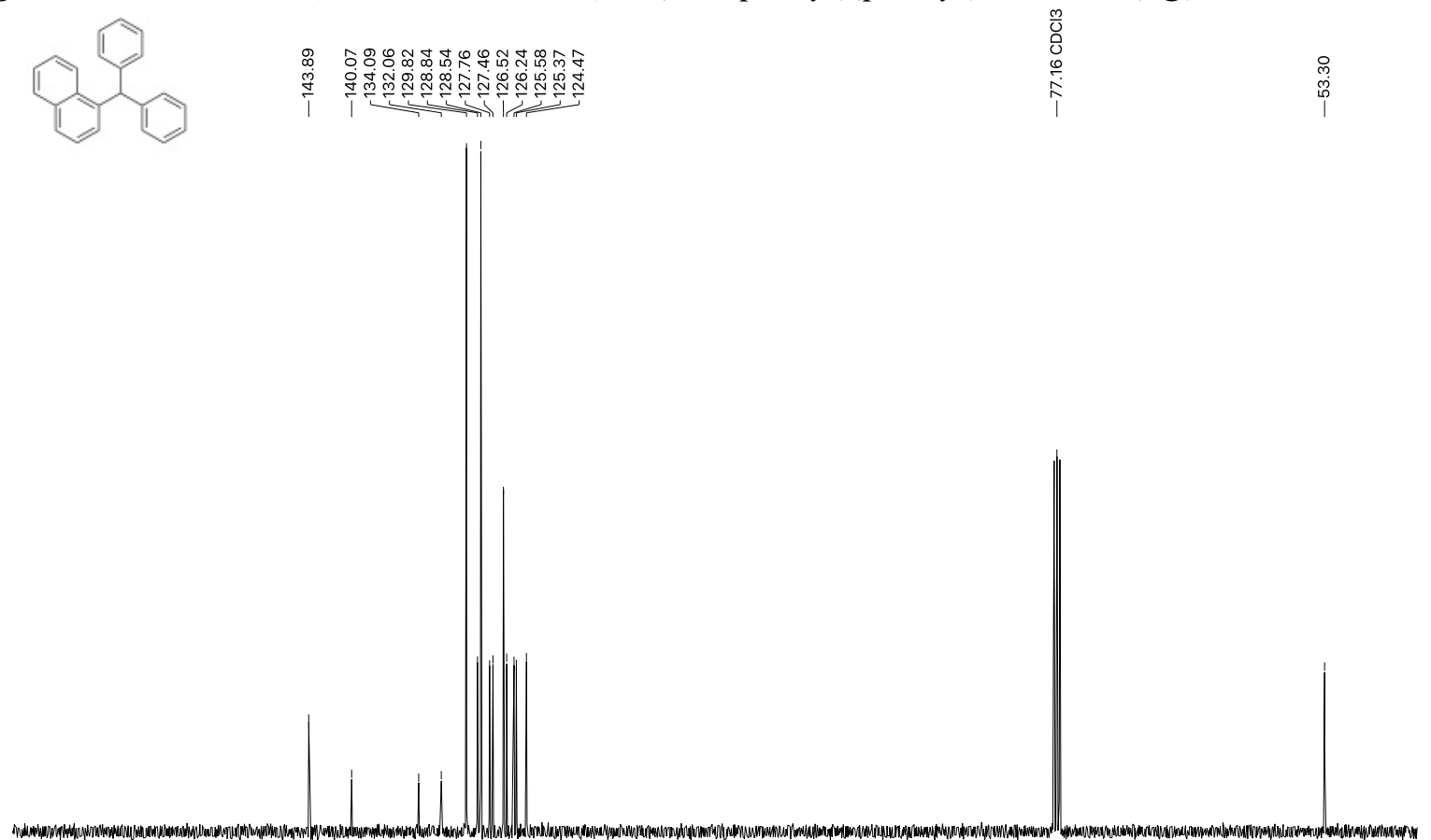

$\begin{array}{lllllllllllllllllllllllllll}70 & 165 & 160 & 155 & 150 & 145 & 140 & 135 & 130 & 125 & 120 & 115 & 110 & 105 & 100 & 95 & 90 & 85 & 80 & 75 & 70 & 65 & 60 & 55 & 50 & \end{array}$

Figure S71: ${ }^{13} \mathrm{C}\left\{{ }^{1} \mathrm{H}\right\} \mathrm{NMR}\left(\mathrm{CDCl}_{3}, 126 \mathrm{MHz}\right)$ of (1-naphthyl)(phenyl) methane (6g) 


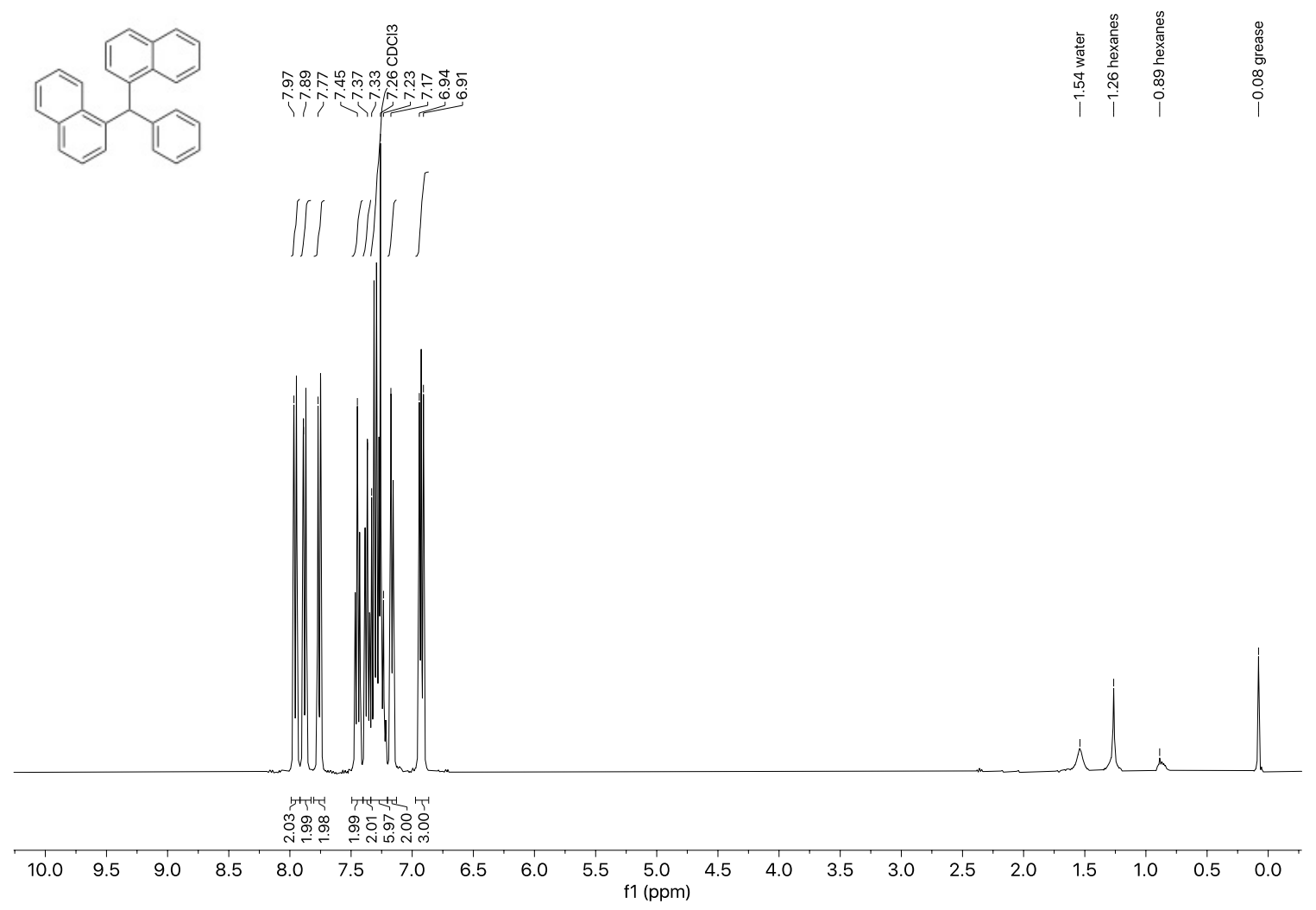

Figure S72: ${ }^{1} \mathrm{H} \mathrm{NMR}\left(\mathrm{CDCl}_{3}, 400 \mathrm{MHz}\right)$ of (di-1-naphthyl)(phenyl) methane (6h)
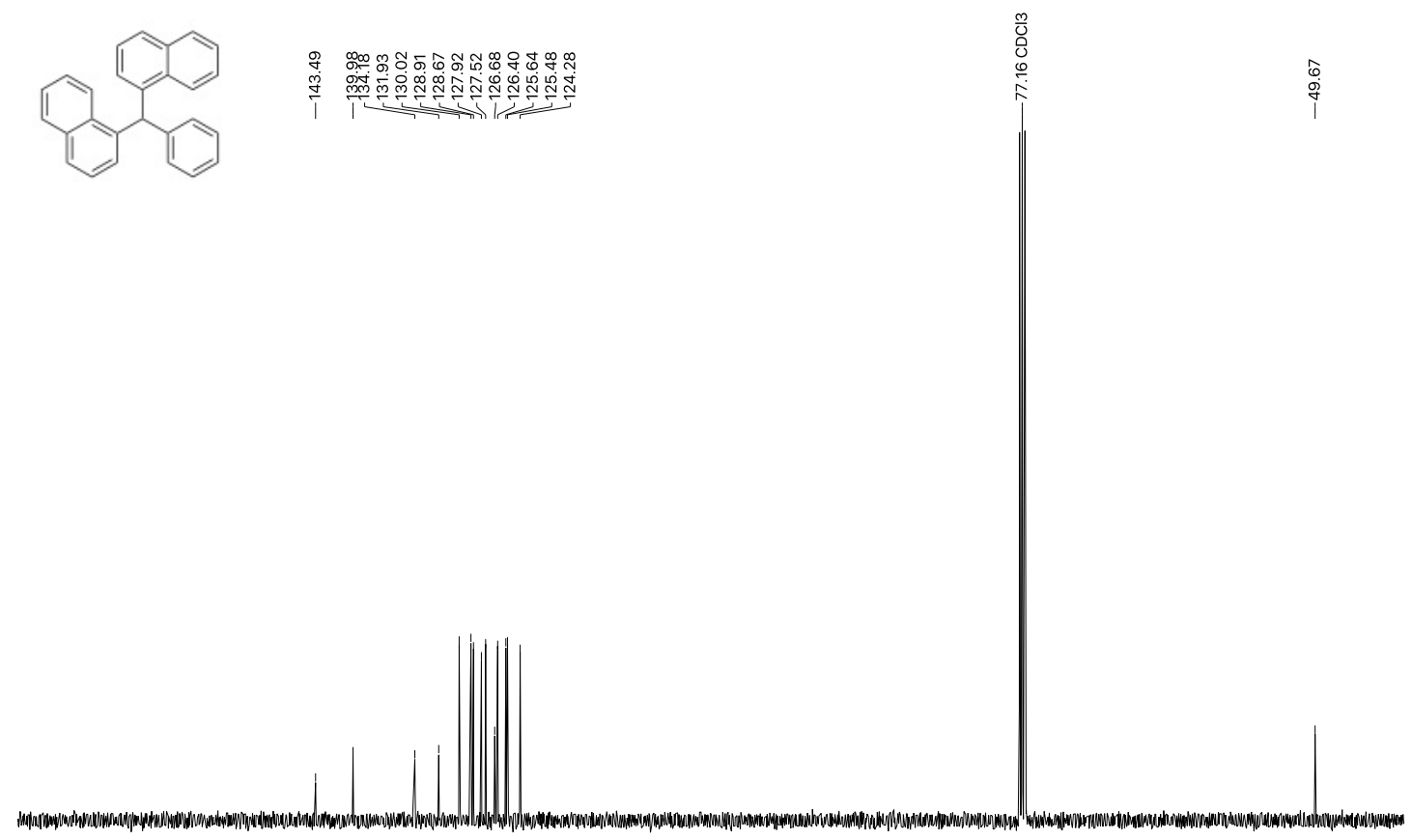

$\begin{array}{lllllllllllllllllllllllllll}170 & 165 & 160 & 155 & 150 & 145 & 140 & 135 & 130 & 125 & 120 & 115 & \begin{array}{c}110 \\ \mathrm{f} 1(\mathrm{ppm})\end{array} & 105 & 95 & 90 & 85 & 80 & 75 & 70 & 65 & 60 & 55 & 50 & 45\end{array}$

Figure S73: ${ }^{13} \mathrm{C}\left\{{ }^{1} \mathrm{H}\right\} \mathrm{NMR}\left(\mathrm{CDCl}_{3}, 126 \mathrm{MHz}\right)$ of (di-1-naphthyl)(phenyl) methane (6h) 

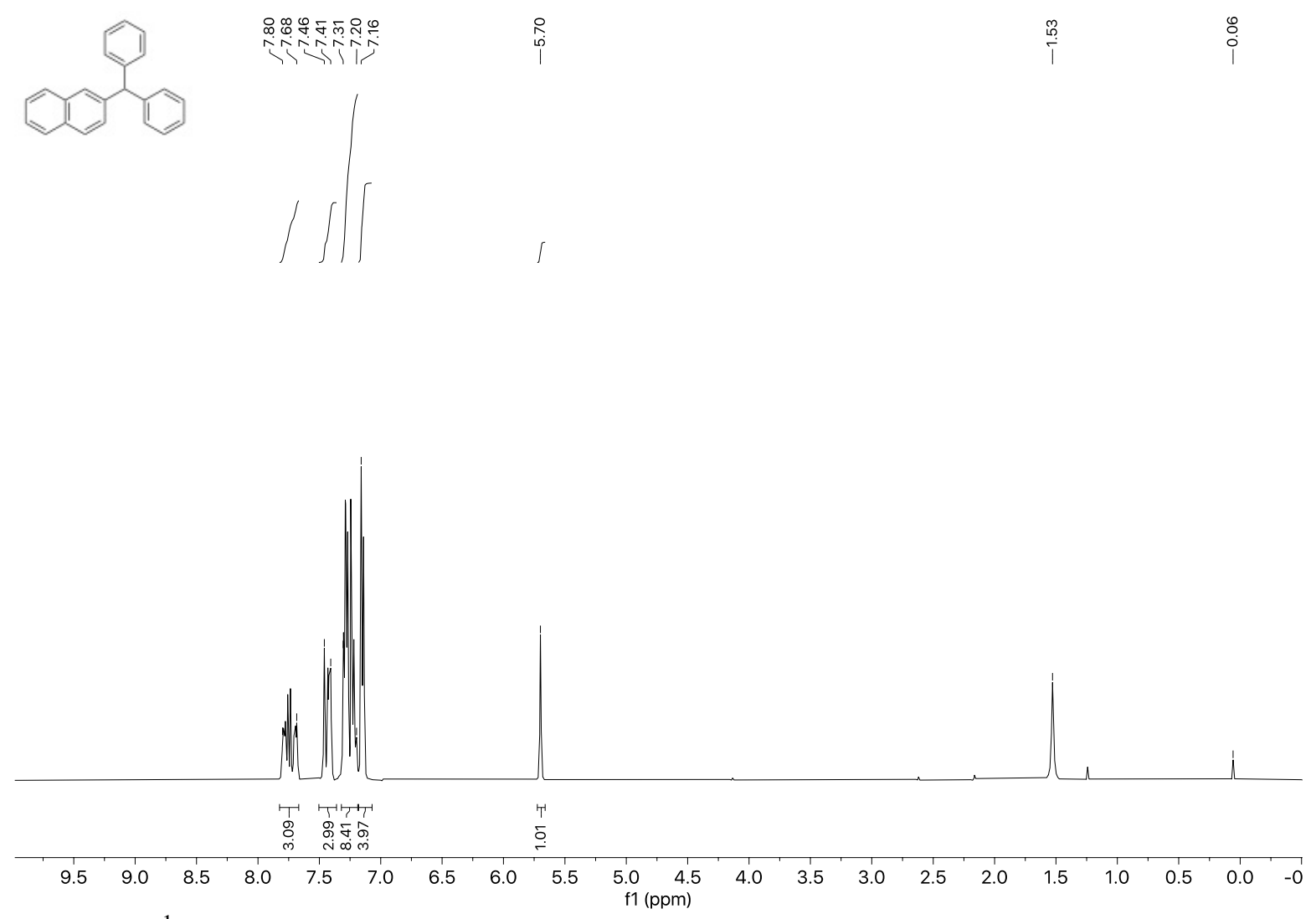

Figure S74: ${ }^{1} \mathrm{H} \mathrm{NMR}\left(\mathrm{CDCl}_{3}, 400 \mathrm{MHz}\right)$ of (2-naphthyl)(phenyl) methane (6i)
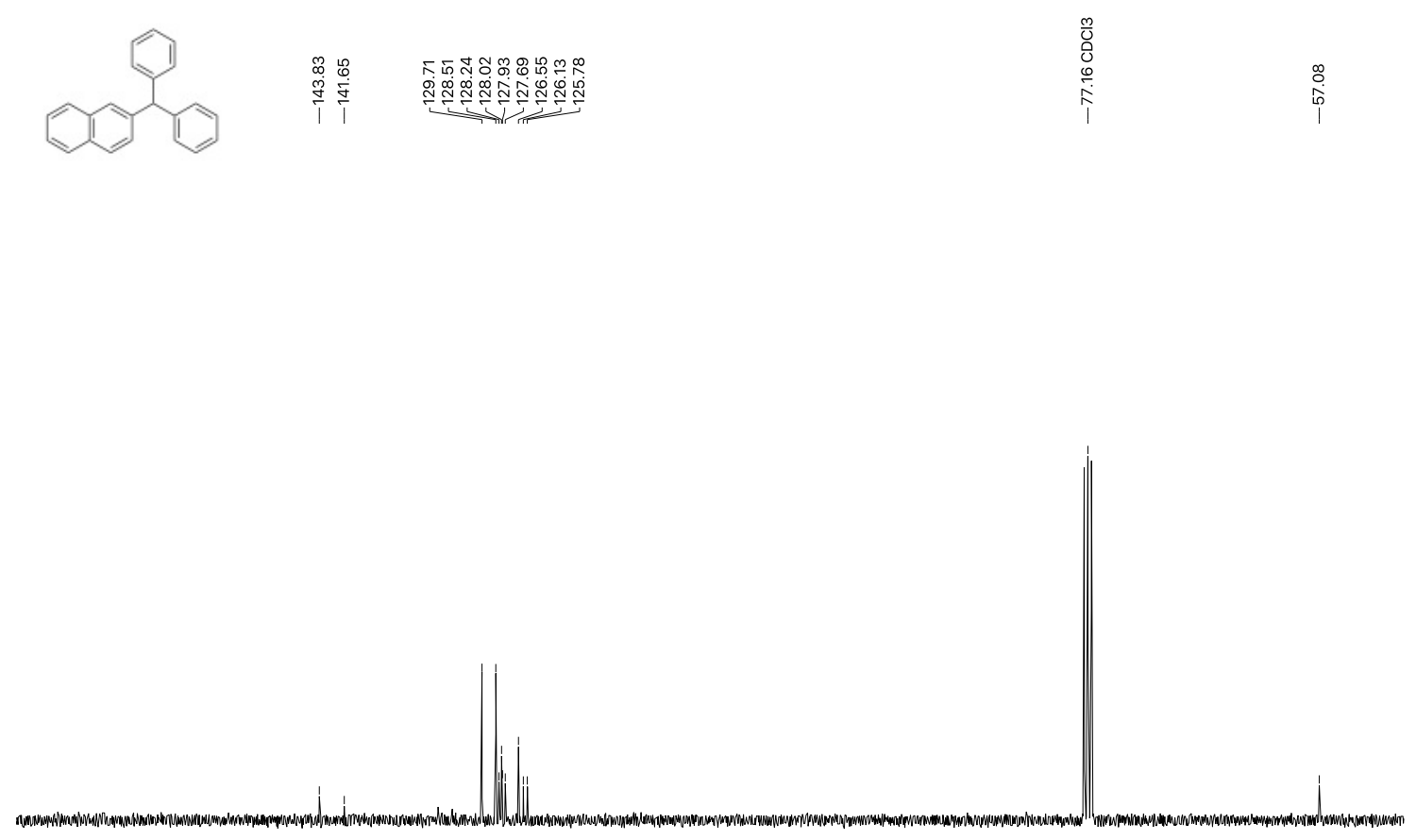

$\begin{array}{lllllllllllllllllllllllll}70 & 165 & 160 & 155 & 150 & 145 & 140 & 135 & 130 & 125 & 120 & 115 & \begin{array}{l}110 \\ \mathrm{f} 1(\mathrm{ppm})\end{array} & 105 & 100 & 95 & 90 & 85 & 80 & 75 & 70 & 65 & 60 & 55 & 51\end{array}$

Figure S75: ${ }^{13} \mathrm{C}\left\{{ }^{1} \mathrm{H}\right\} \mathrm{NMR}\left(\mathrm{CDCl}_{3}, 101 \mathrm{MHz}\right)$ of (2-naphthyl)(phenyl) methane (6i) 


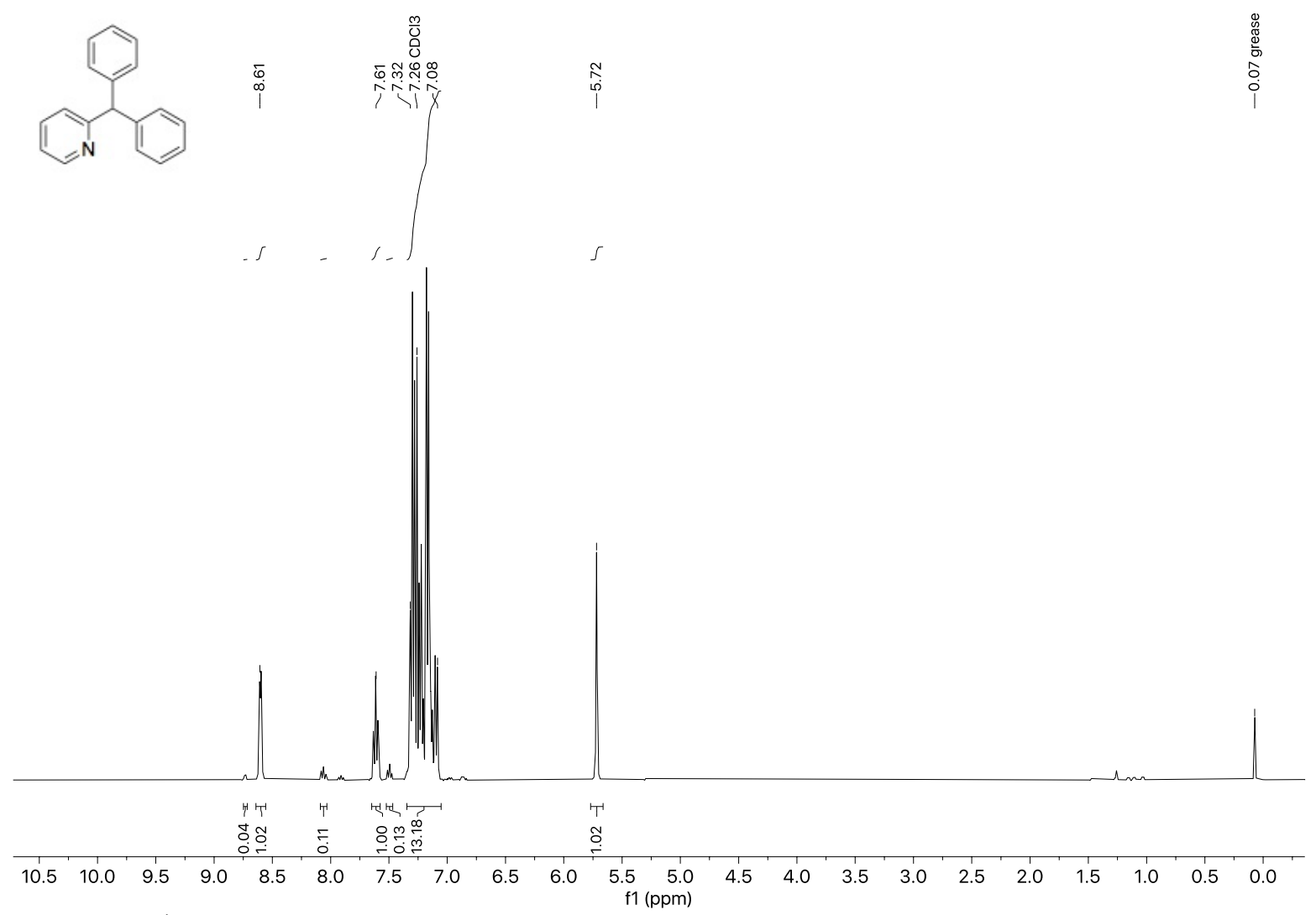

Figure S76: ${ }^{1} \mathrm{H} \mathrm{NMR}\left(\mathrm{CDCl}_{3}, 400 \mathrm{MHz}\right)$ of (diphenyl)(2-pyridyl) methane $(\mathbf{6 j})$
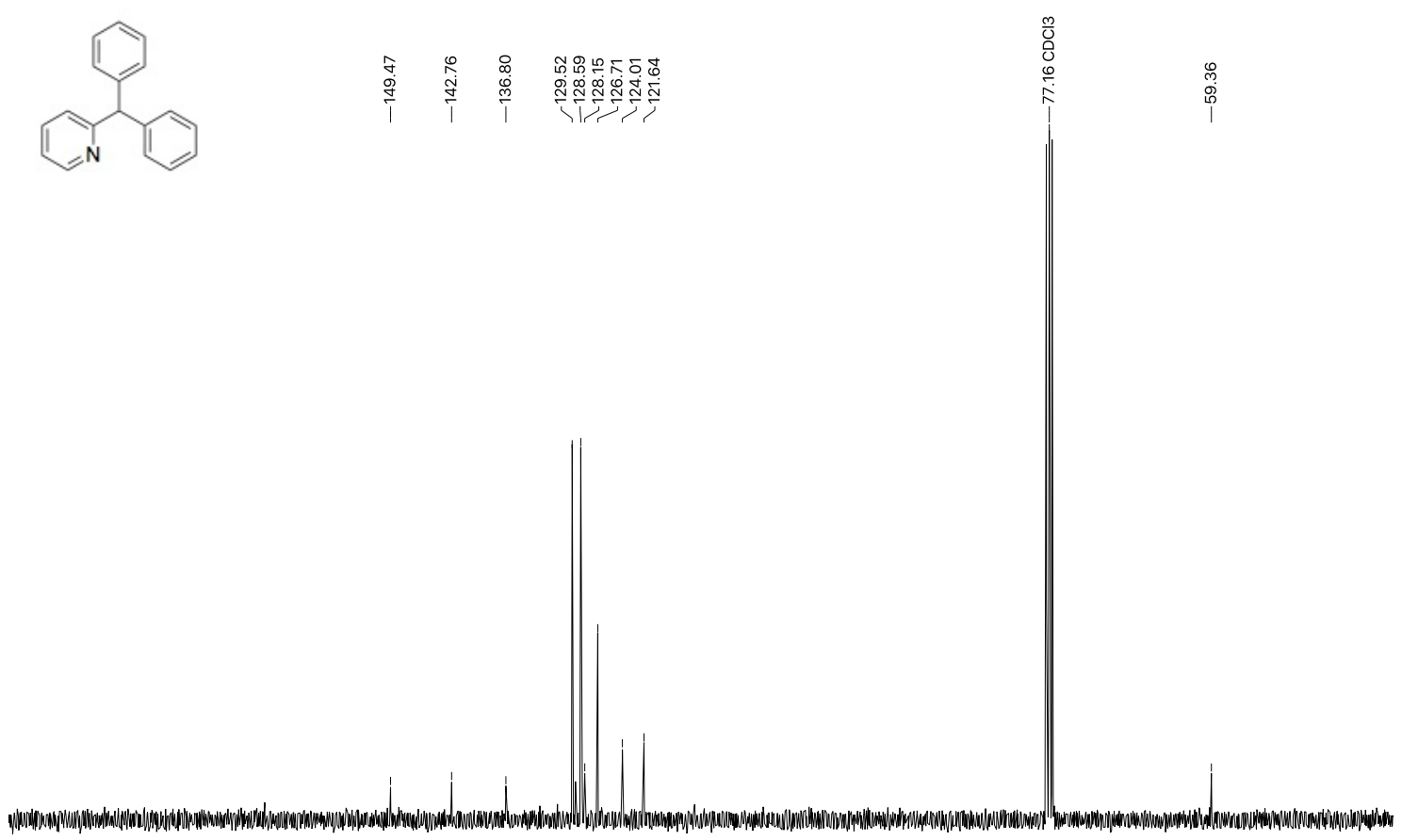

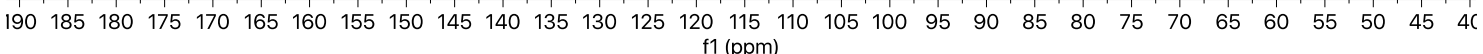

Figure S77: ${ }^{13} \mathrm{C}\left\{{ }^{1} \mathrm{H}\right\}$ NMR $\left(\mathrm{CDCl}_{3}, 101 \mathrm{MHz}\right)$ of (diphenyl)(2-pyridyl) methane (6j) 


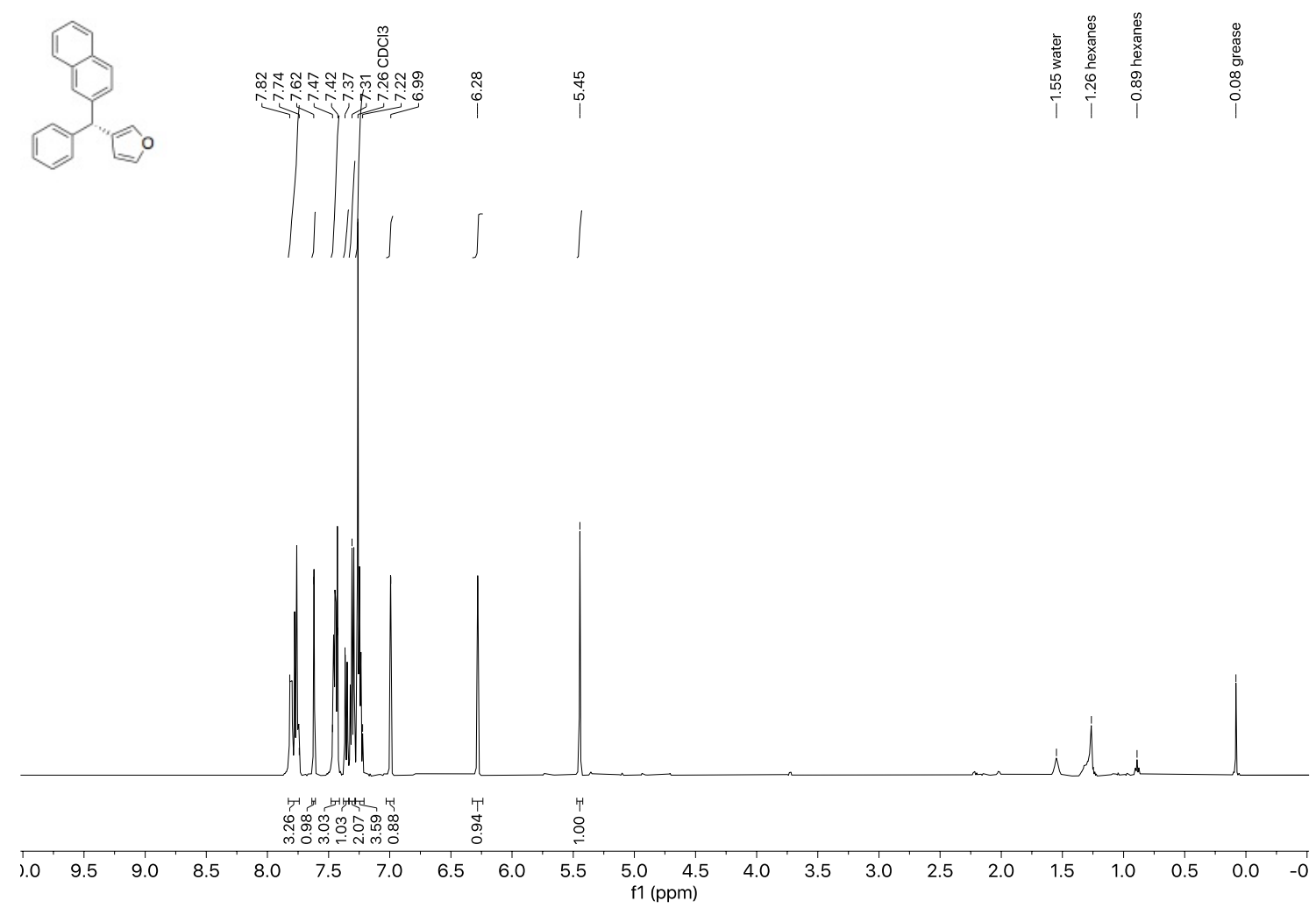

Figure S78: ${ }^{1} \mathrm{H} \mathrm{NMR}\left(\mathrm{CDCl}_{3}, 500 \mathrm{MHz}\right)$ of $(R)-(3-$ furyl)(2-naphthyl)(phenyl)methane (7a)
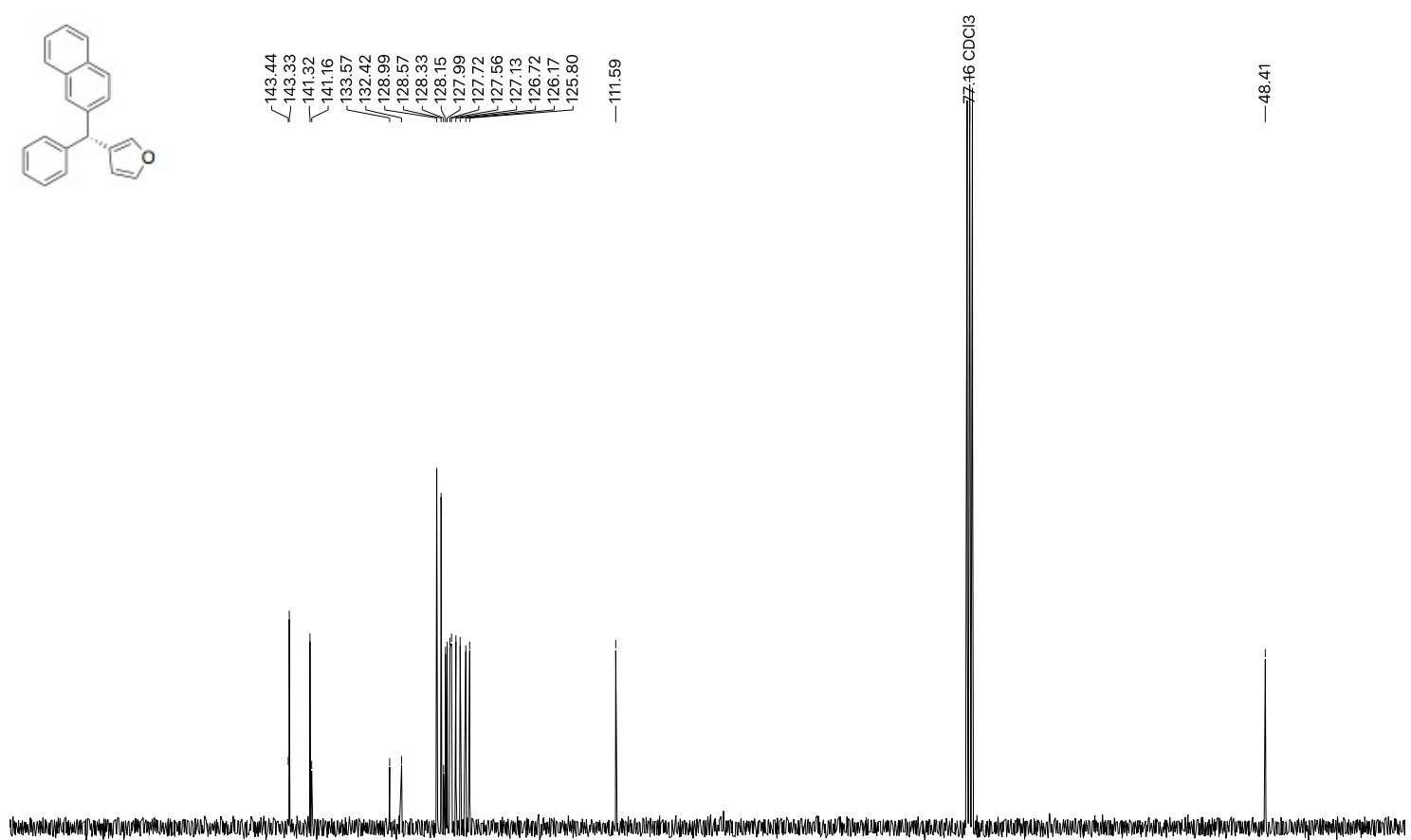

$\begin{array}{lllllllllllllllllllllllllllll}70 & 165 & 160 & 155 & 150 & 145 & 140 & 135 & 130 & 125 & 120 & 115 & 110 & \begin{array}{c}105 \\ \mathrm{f} 1(\mathrm{ppm})\end{array} & 100 & 90 & 85 & 80 & 75 & 70 & 65 & 60 & 55 & 50 & 45 & 40 & 3\end{array}$

Figure S79: ${ }^{13} \mathrm{C}\left\{{ }^{1} \mathrm{H}\right\} \mathrm{NMR}\left(\mathrm{CDCl}_{3}, 126 \mathrm{MHz}\right)$ of $(R)-(3-$ furyl $)(2$-naphthyl)(phenyl)methane (7a) 
(R)-(4-methylphenyl)(4-methoxyphenyl)(phenyl)methane (7b). ${ }^{1} \mathrm{H} \mathrm{NMR}\left(\mathrm{CDCl}_{3}, 400 \mathrm{MHz}\right)$

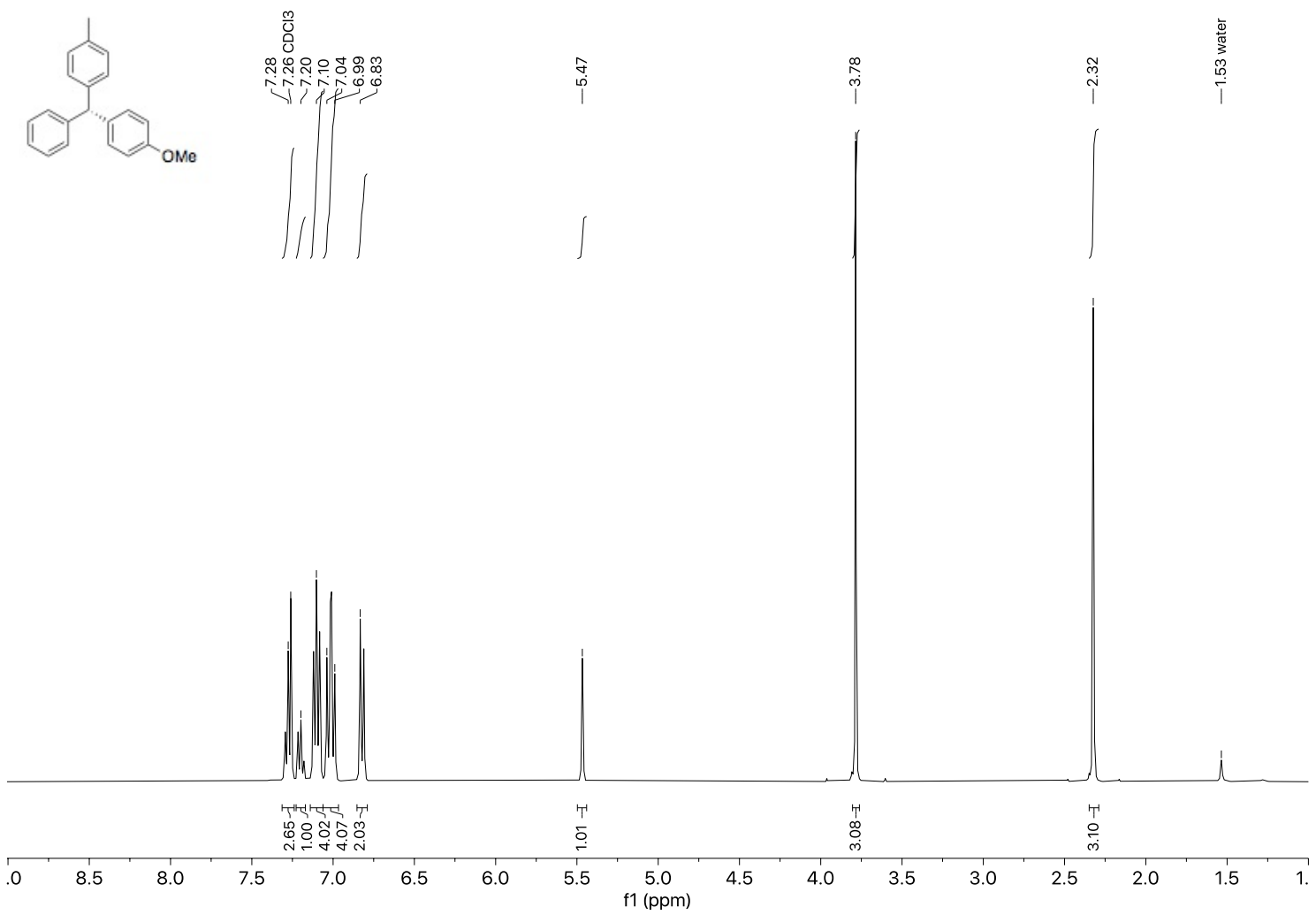

Figure S80: $\quad{ }^{1} \mathrm{H} \quad \mathrm{NMR} \quad\left(\mathrm{CDCl}_{3}, \quad 400 \quad \mathrm{MHz}\right) \quad$ of $\quad(R)$-(4-methylphenyl)(4methoxyphenyl)(phenyl)methane (7b) 

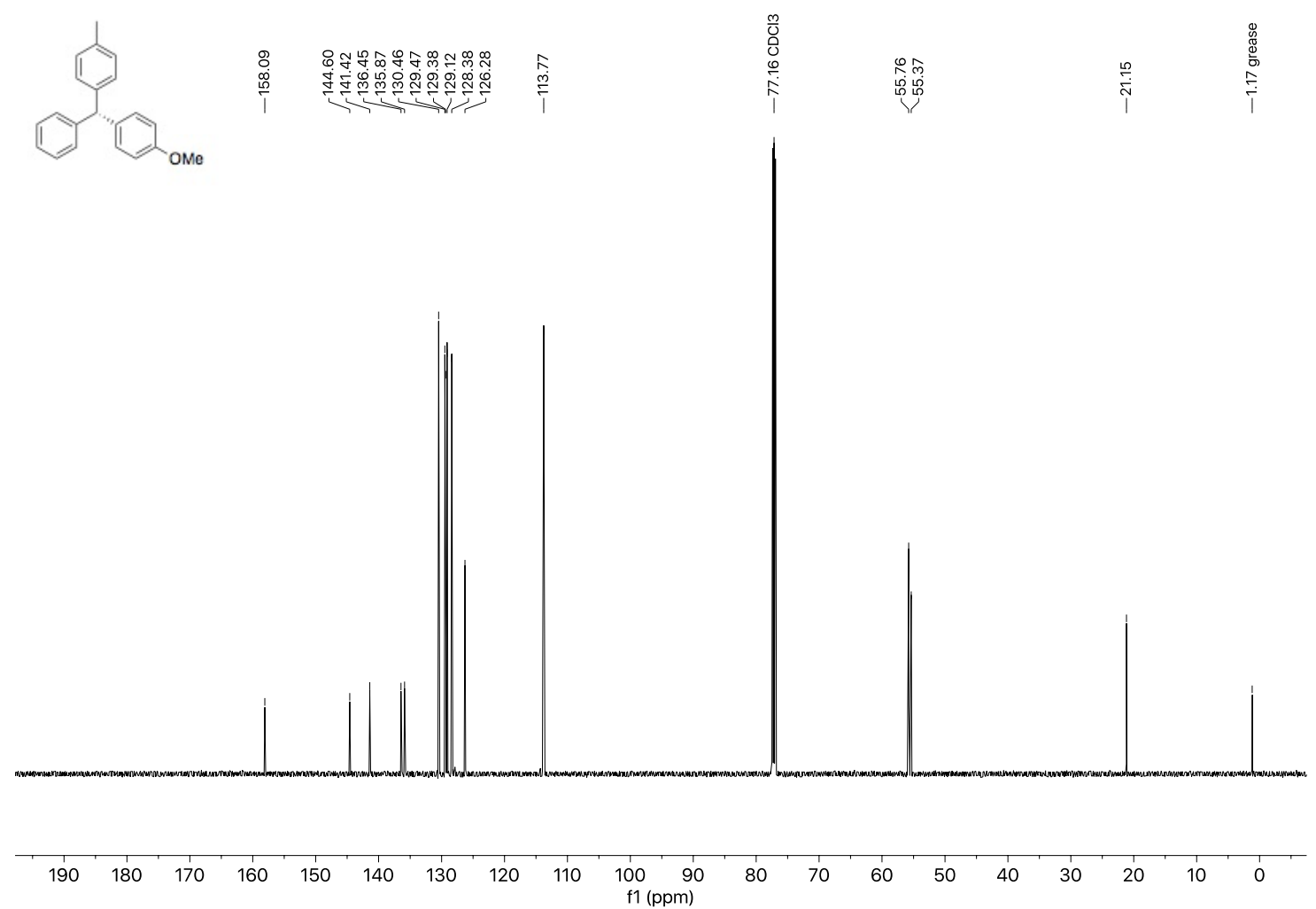

Figure S81: ${ }^{13} \mathrm{C}\left\{{ }^{1} \mathrm{H}\right\} \quad \mathrm{NMR} \quad\left(\mathrm{CDCl}_{3}, \quad 151 \quad \mathrm{MHz}\right) \quad$ of $\quad(R)$-(4-methylphenyl)(4methoxyphenyl)(phenyl)methane (7b) 


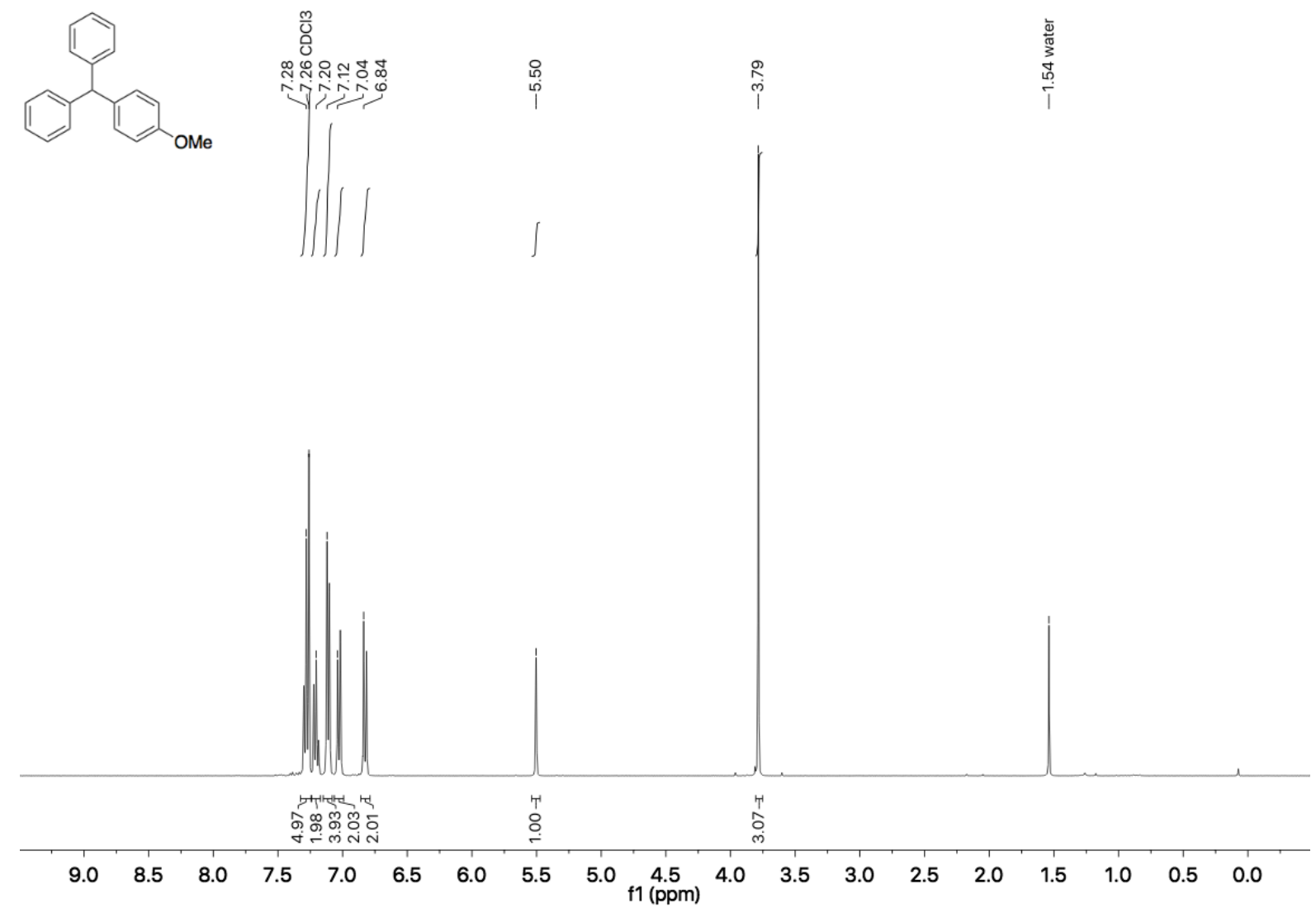

Figure S82: ${ }^{1} \mathrm{H} \mathrm{NMR}\left(\mathrm{CDCl}_{3}, 400 \mathrm{MHz}\right)$ of (4-methoxyphenyl)(diphenyl) methane (8b)
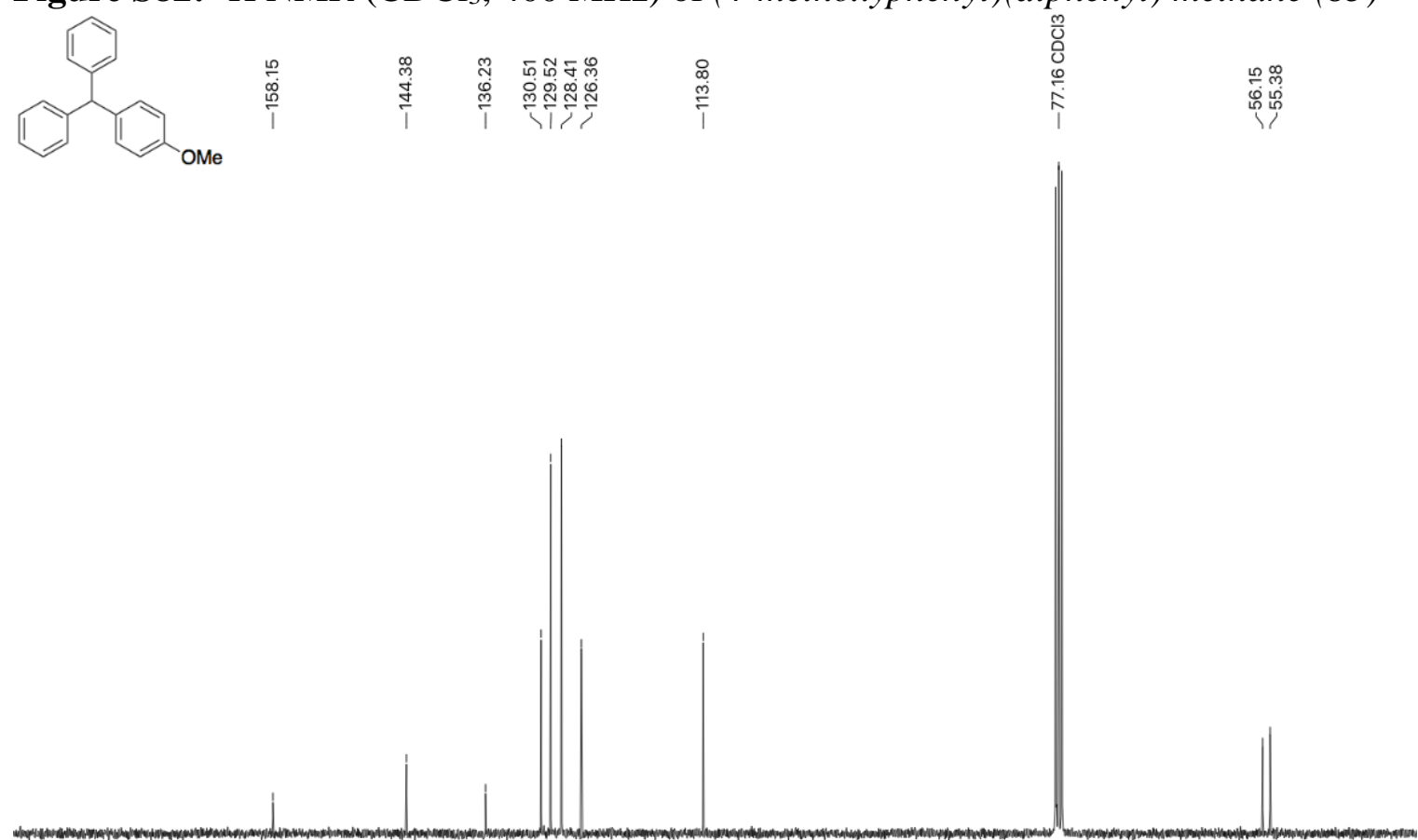

$180175170165160155150145140135130125120 \begin{gathered}115 \\ \mathrm{f}(\mathrm{ppm})\end{gathered} 105100 \quad 95 \quad 90 \quad 85 \quad 80 \quad 75 \quad 70 \quad 65 \quad 60 \quad 55 \quad 50 \quad 45$

Figure S83: ${ }^{13} \mathrm{C}\left\{{ }^{1} \mathrm{H}\right\} \mathrm{NMR}\left(\mathrm{CDCl}_{3}, 101 \mathrm{MHz}\right)$ of (4-methoxyphenyl)(diphenyl) methane (8b) 


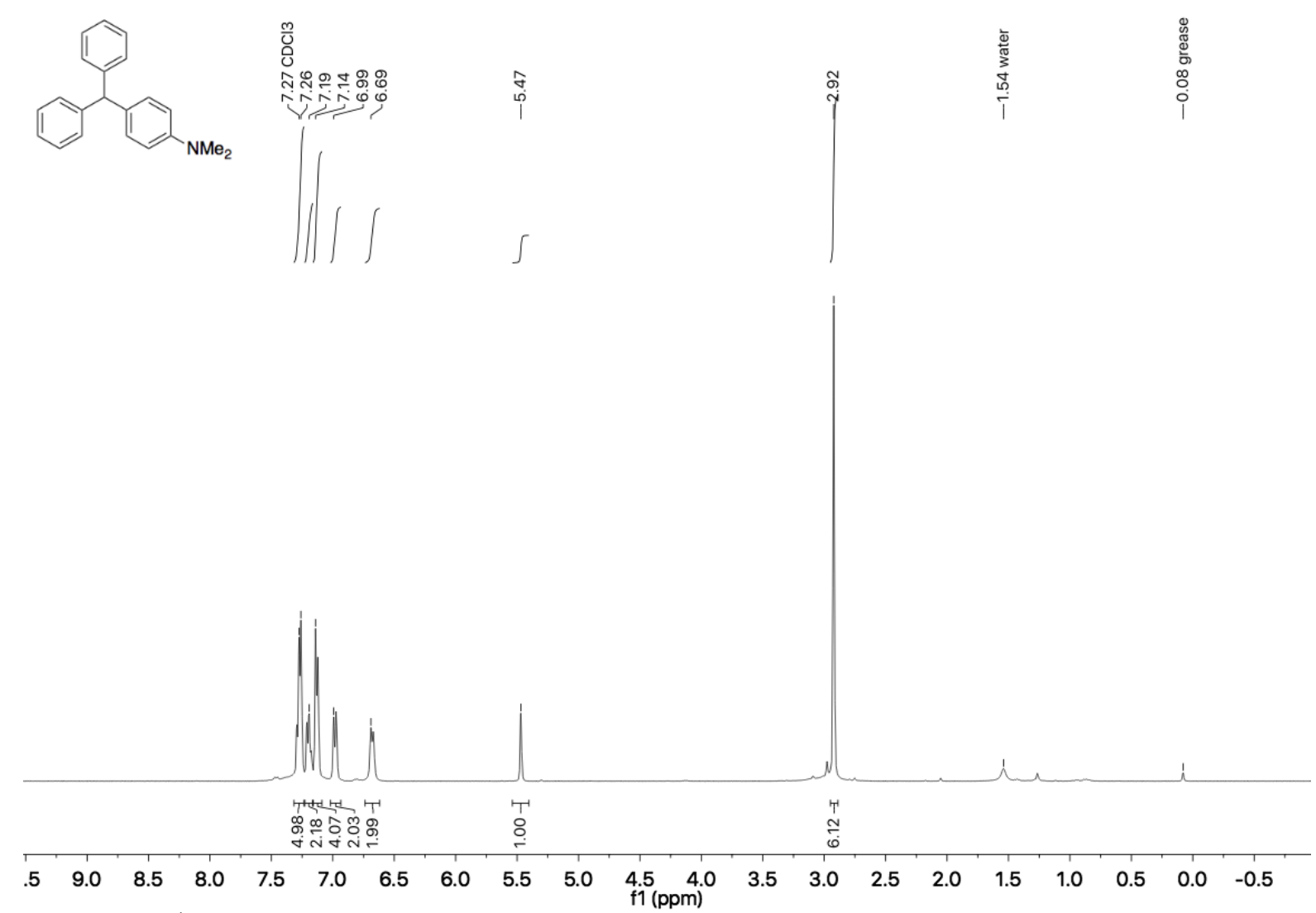

Figure S84: ${ }^{1} \mathrm{H} \mathrm{NMR}\left(\mathrm{CDCl}_{3}, 400 \mathrm{MHz}\right)$ of (4-dimethylaminophenyl)(diphenyl) methane (8c) 


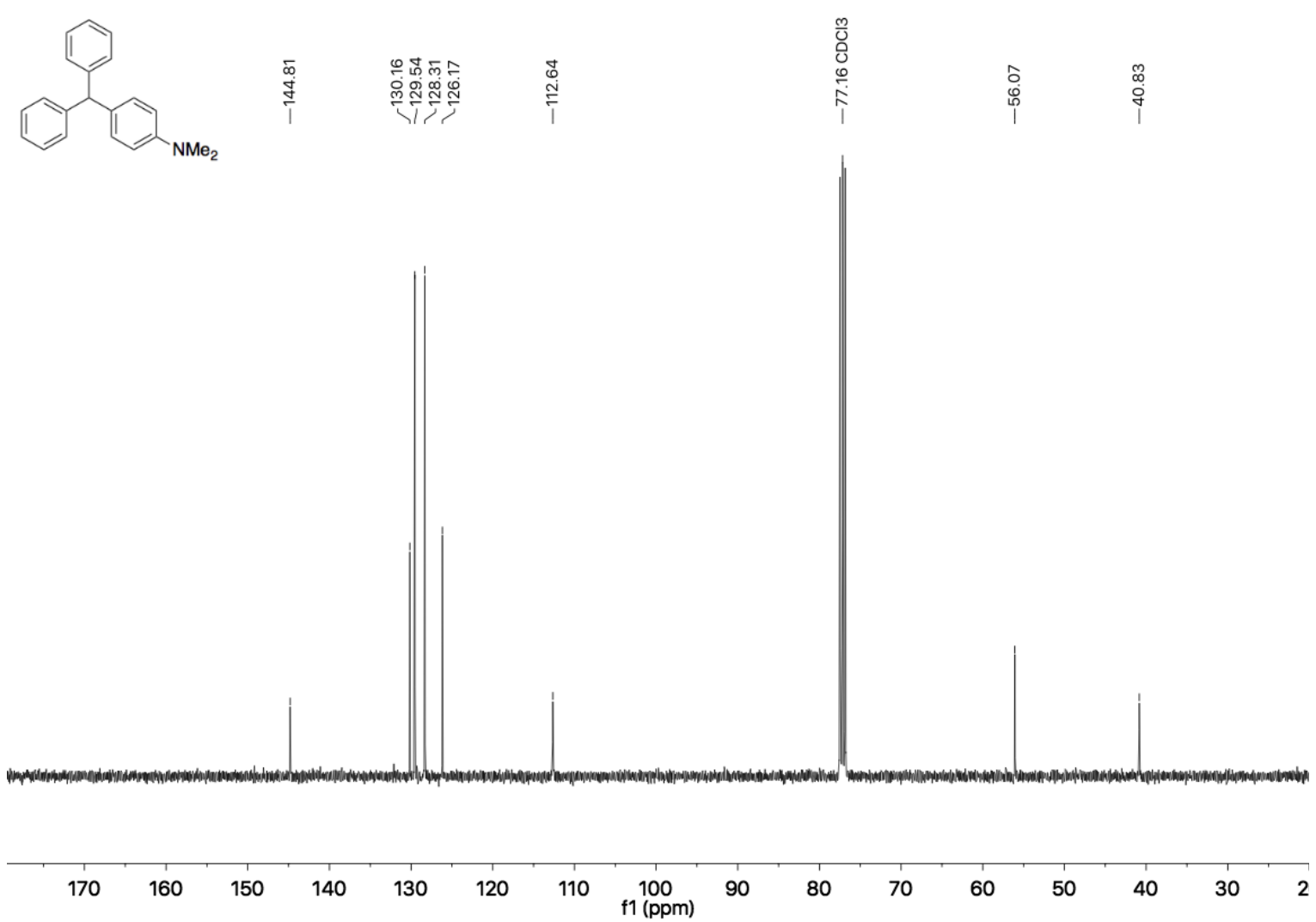

Figure S85: ${ }^{13} \mathrm{C}\left\{{ }^{1} \mathrm{H}\right\} \mathrm{NMR}\left(\mathrm{CDCl}_{3}, 101 \mathrm{MHz}\right)$ of (4-dimethylaminophenyl)(diphenyl) methane $(8 c)$ 


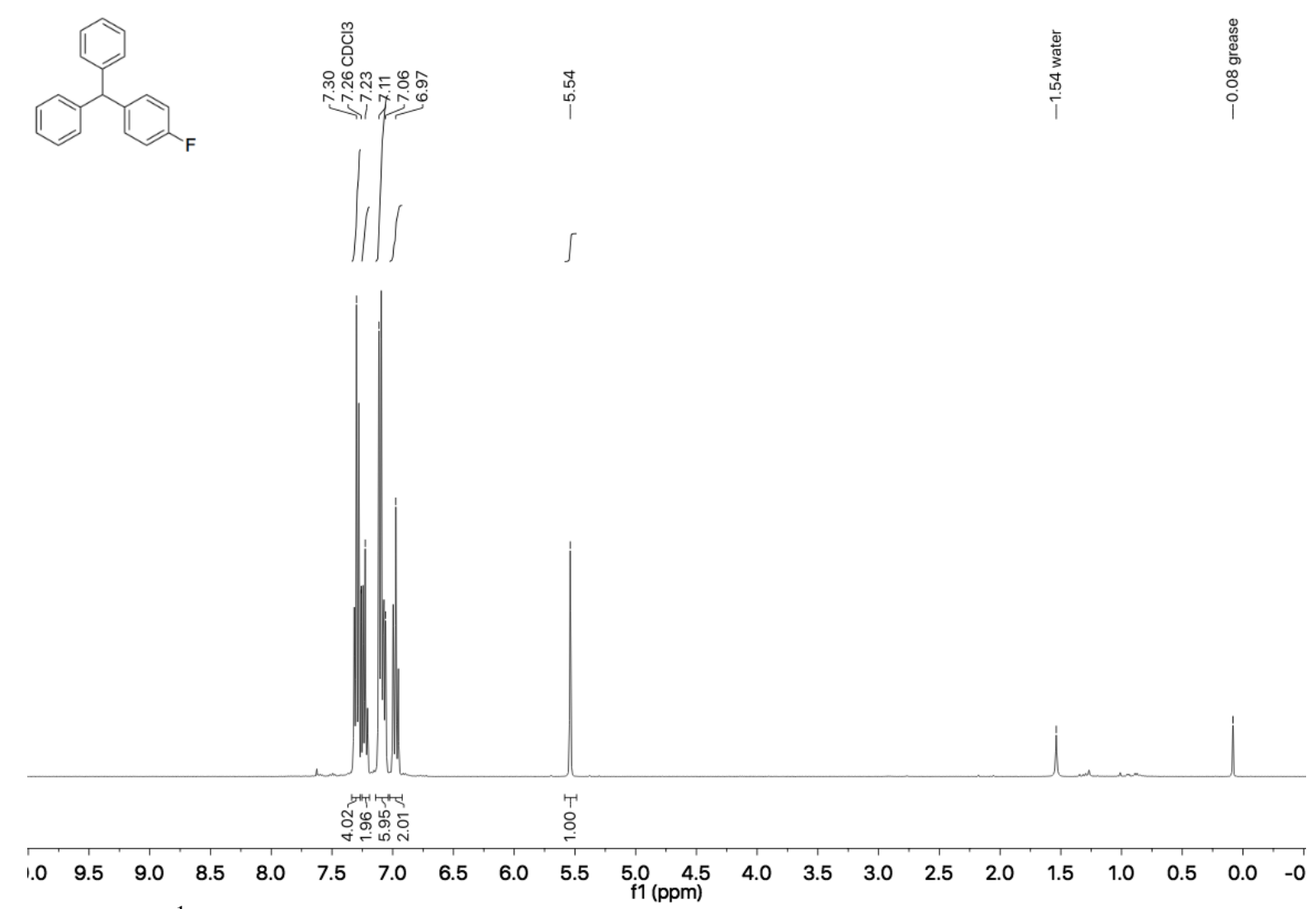

Figure S86: ${ }^{1} \mathrm{H} \mathrm{NMR}\left(\mathrm{CDCl}_{3}, 400 \mathrm{MHz}\right)$ of (4-fluorophenyl)(diphenyl) methane (8d)

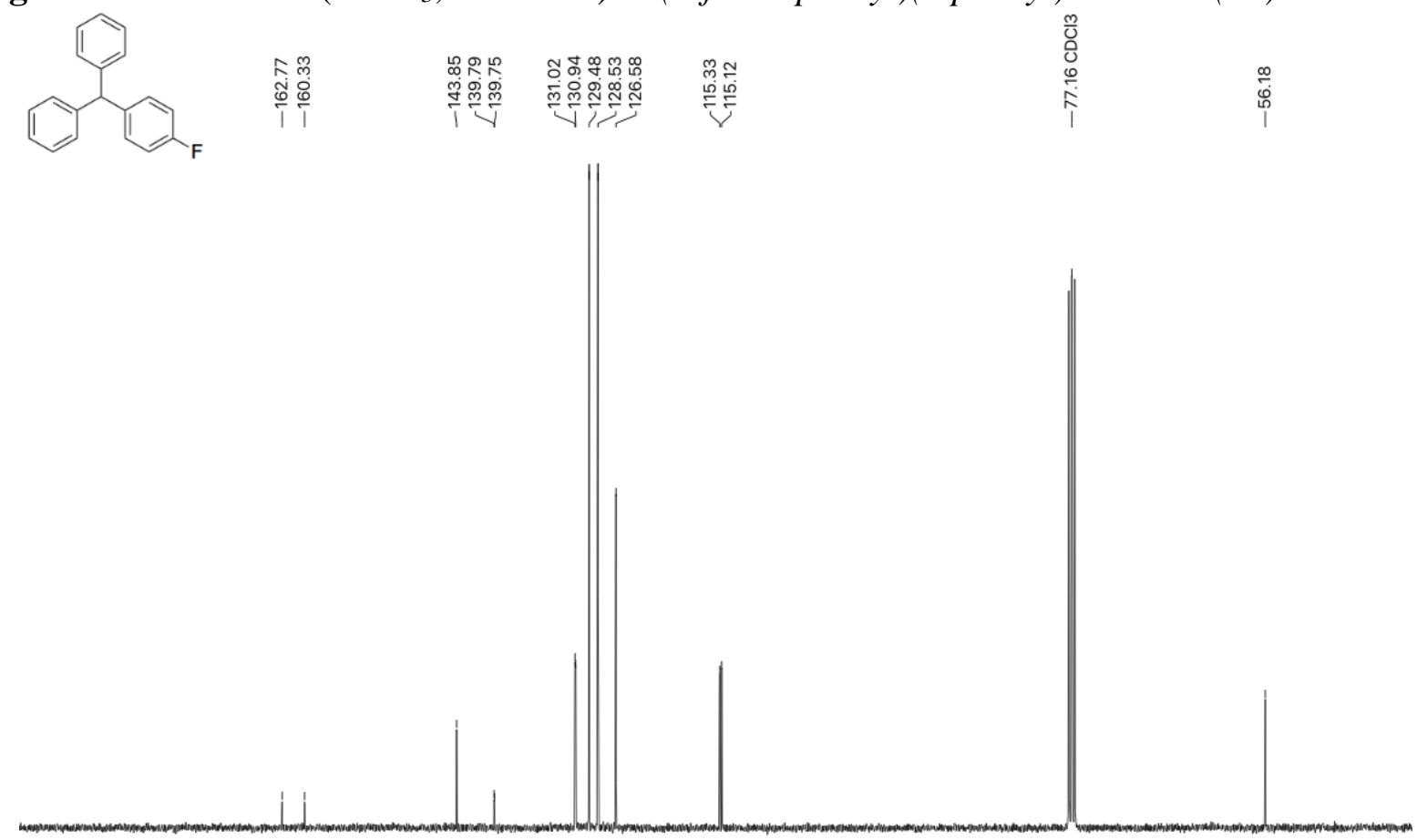

$90185180175170165160155150145140135130125120115 \quad 11010510095 \quad 90 \quad 85 \quad 8075 \quad 70 \quad 65 \quad 60 \quad 55 \quad 50 \quad 45$ $11(\mathrm{ppm})$

Figure S87: ${ }^{13} \mathrm{C}\left\{{ }^{1} \mathrm{H}\right\}$ NMR $\left(\mathrm{CDCl}_{3}, 101 \mathrm{MHz}\right)$ of (4-fluorophenyl)(diphenyl) methane (8d) 


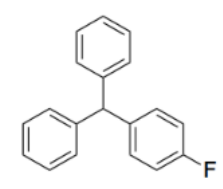

$\begin{array}{lllllllllllll}-45 & -50 & -55 & -60 & -65 & -70 & -75 & -80 & -85 & -90 & -95 & -100 & -105\end{array}$

Figure S88: ${ }^{19} \mathrm{~F} \mathrm{NMR}\left(\mathrm{CDCl}_{3}, 376 \mathrm{MHz}\right)$ of (4-fluorophenyl)(diphenyl) methane (8d) 


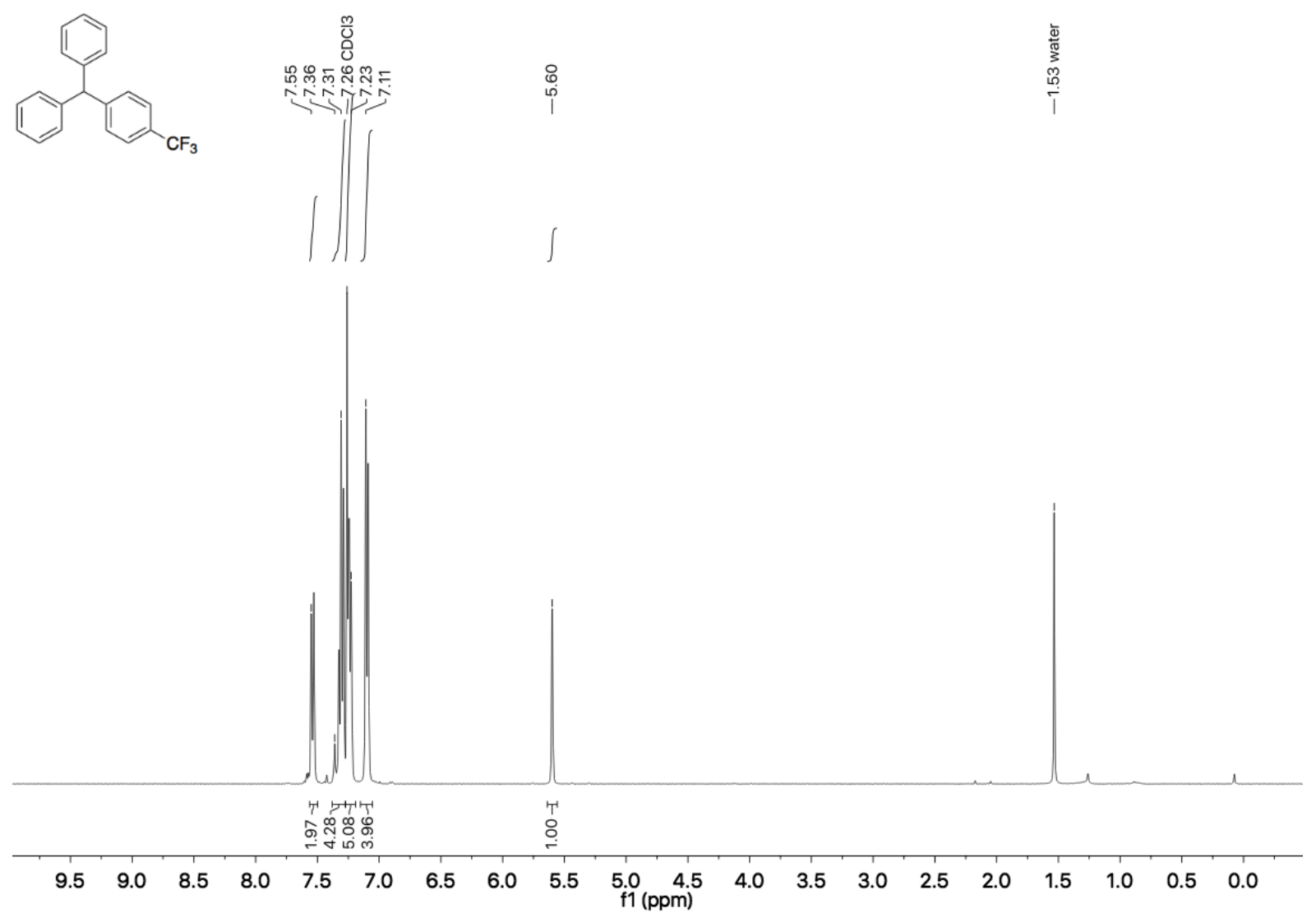

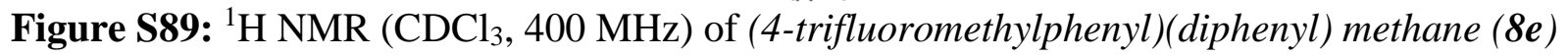



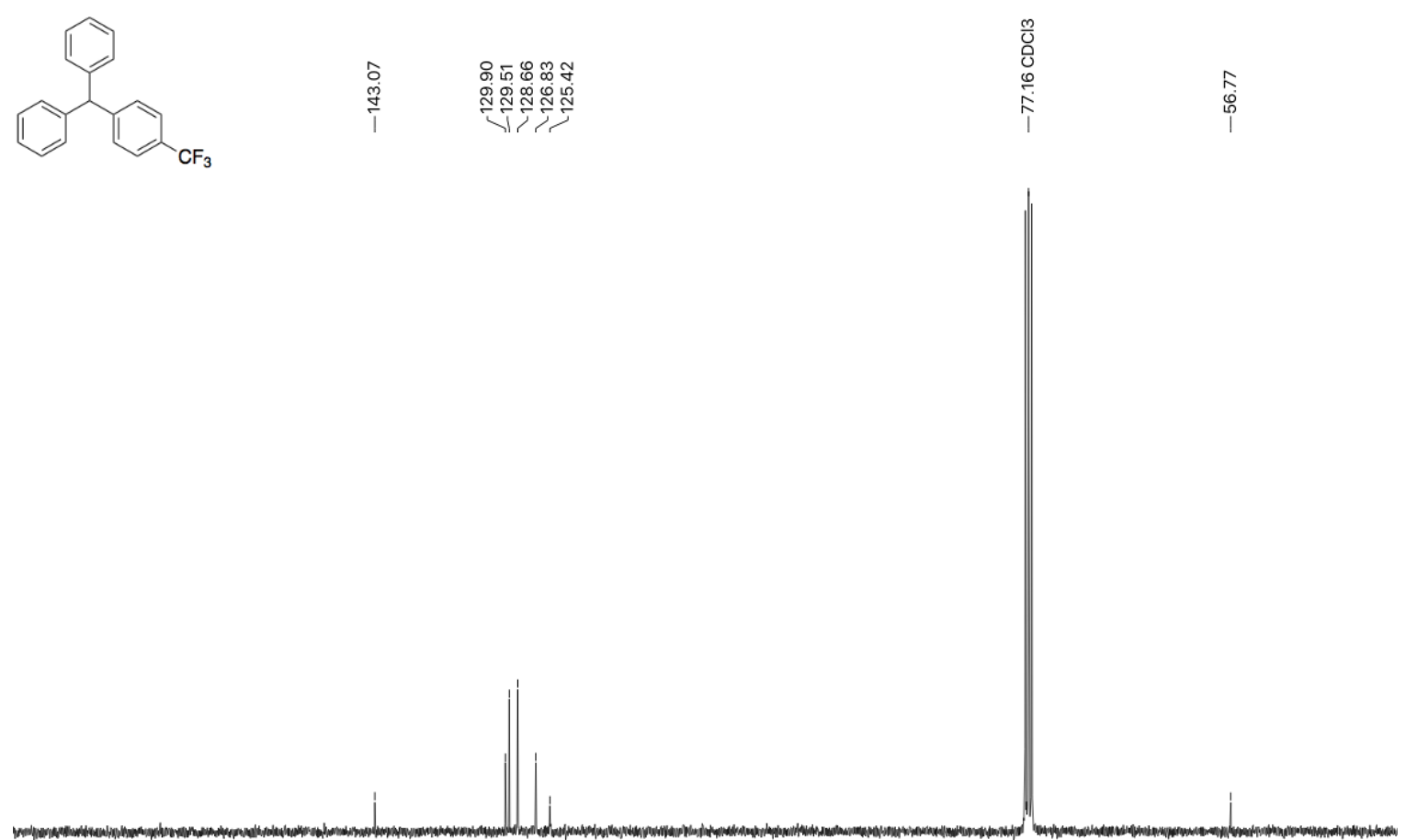

$\begin{array}{llllllllllllllllllllllllllll}175 & 170 & 165 & 160 & 155 & 150 & 145 & 140 & 135 & 130 & 125 & 120 & 115 & 110 & 105 & 100 & 95 & 90 & 85 & 80 & 75 & 70 & 65 & 60 & 55 & 50 & 45 & 4\end{array}$ Figure S90: ${ }^{13} \mathrm{C}\left\{{ }^{1} \mathrm{H}\right\}$ NMR $\left(\mathrm{CDCl}_{3}, 101 \mathrm{MHz}\right)$ of (4-trifluoromethylphenyl)(diphenyl) methane $(8 e)$ 


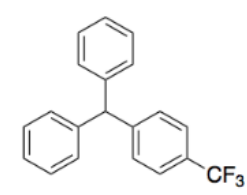

$\begin{array}{lllllllllllllllllllllllllll}30 & 20 & 10 & 0 & -10 & -20 & -30 & -40 & -50 & -60 & -70 & -80 & -90 & -100 & -110 & -120 & -130 & -140 & -150 & -160 & -170 & -180 & -190 & -200\end{array}$ Figure S91: ${ }^{19} \mathrm{~F} \mathrm{NMR}\left(\mathrm{CDCl}_{3}, 376 \mathrm{MHz}\right)$ of (4-trifluoromethylphenyl)(diphenyl) methane (8e) 


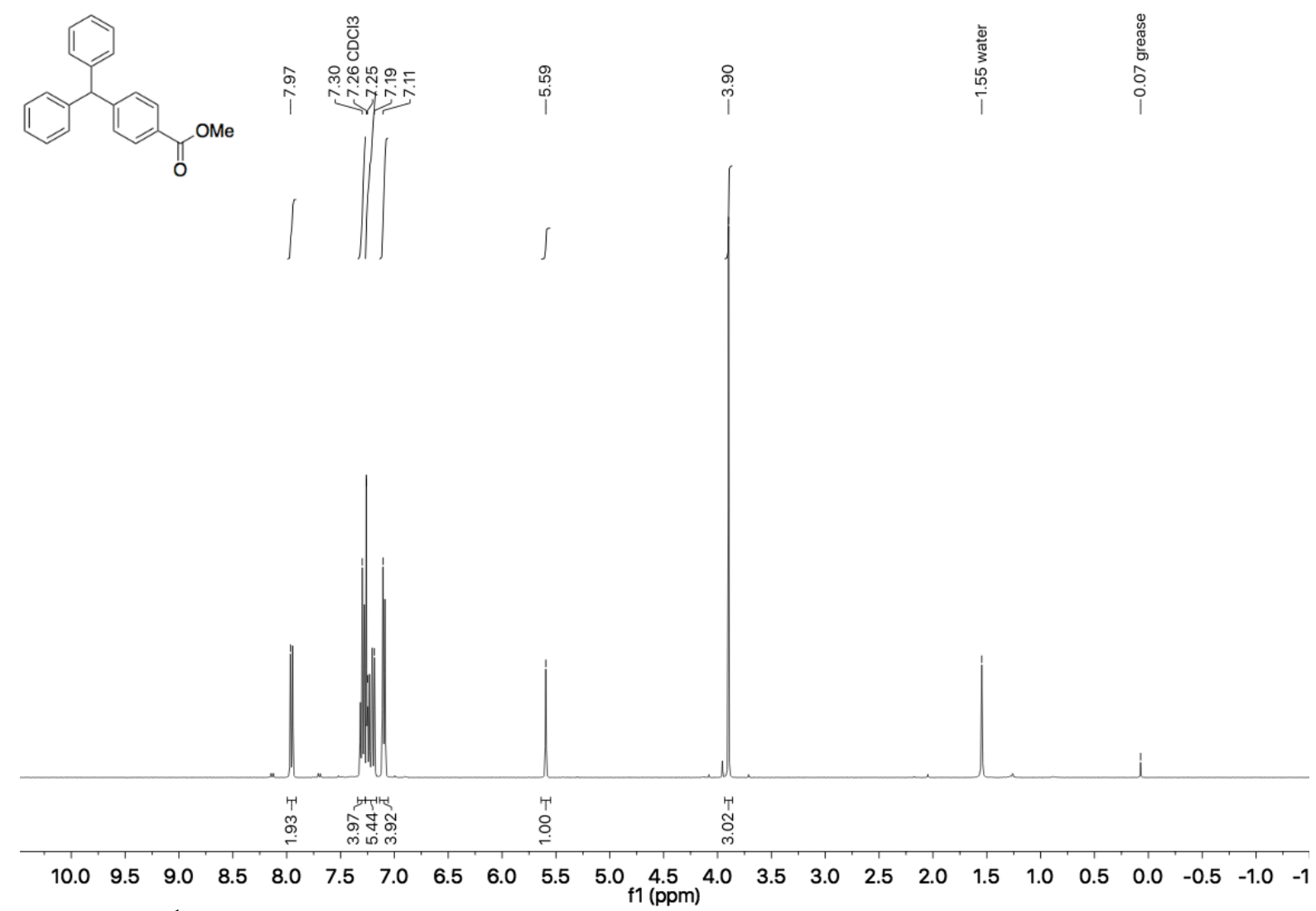

Figure S92: ${ }^{1} \mathrm{H} \mathrm{NMR}\left(\mathrm{CDCl}_{3}, 400 \mathrm{MHz}\right)$ of (4-methylesterphenyl)(diphenyl) methane $(8 f)$
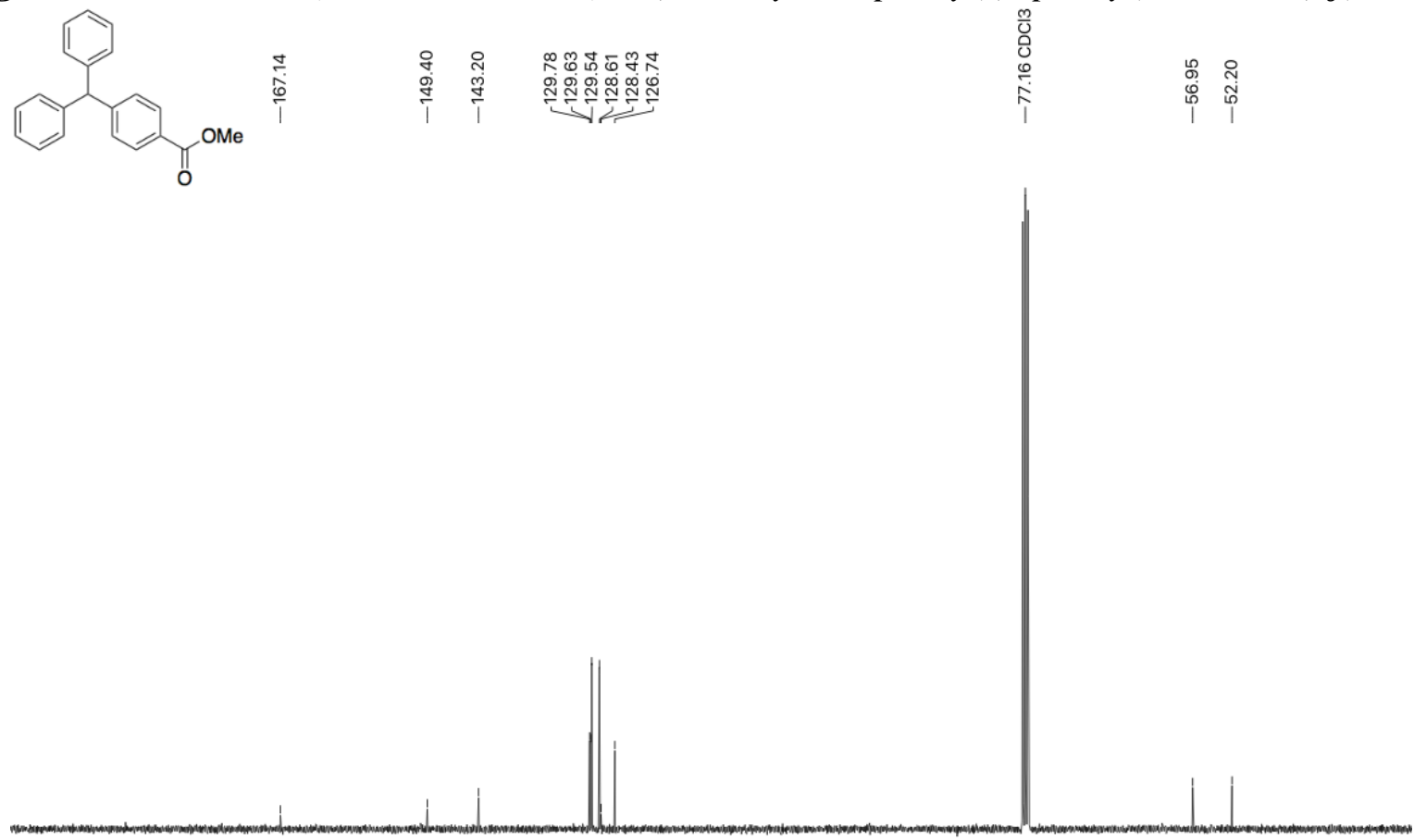

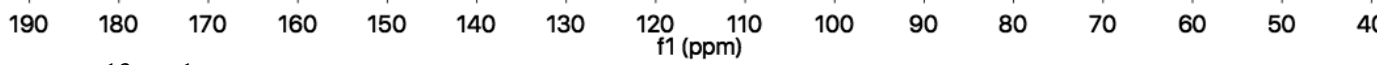

Figure S93: ${ }^{13} \mathrm{C}\left\{{ }^{1} \mathrm{H}\right\} \mathrm{NMR}\left(\mathrm{CDCl}_{3}, 101 \mathrm{MHz}\right)$ of (4-methylesterphenyl)(diphenyl) methane $(\boldsymbol{8 f})$ 

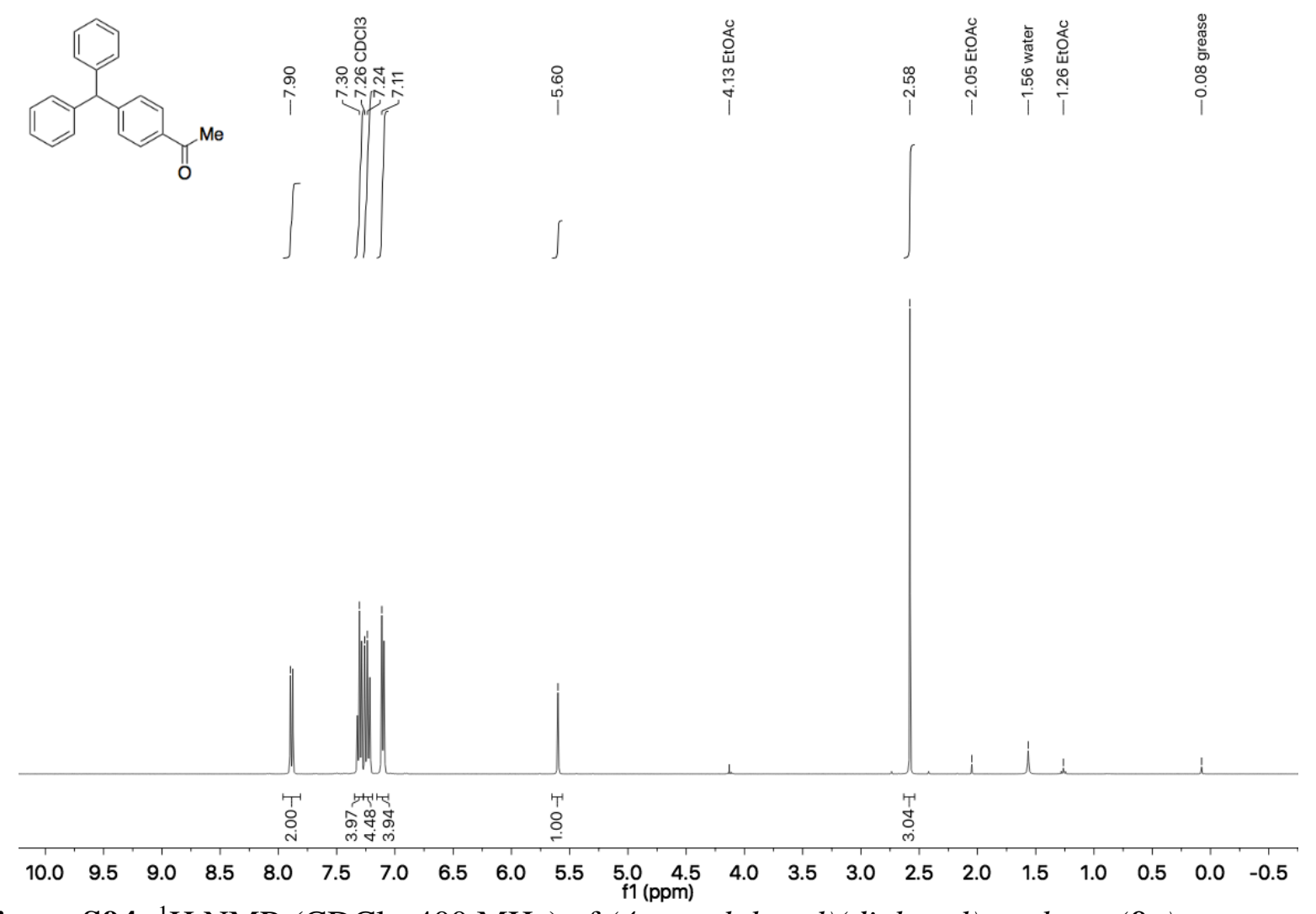

Figure S94: ${ }^{1} \mathrm{H} \mathrm{NMR}\left(\mathrm{CDCl}_{3}, 400 \mathrm{MHz}\right)$ of (4-acetylphenyl)(diphenyl) methane (8g)
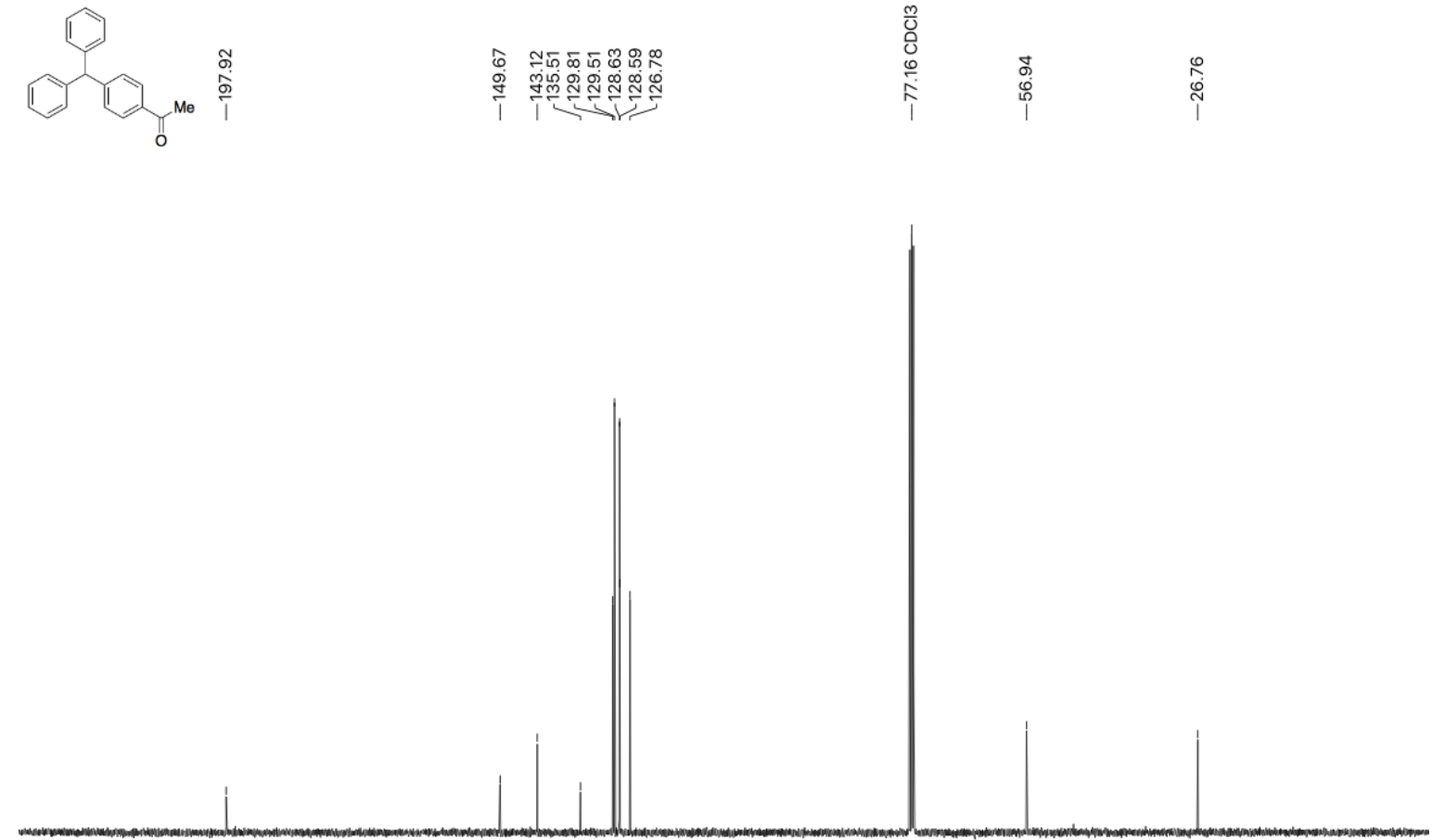

$\begin{array}{llllllllllllllllllllllllll}230 & 220 & 210 & 200 & 190 & 180 & 170 & 160 & 150 & 140 & 130 & 120 & 110 & 100 & 90 & 80 & 70 & 60 & 50 & 40 & 30 & 20 & 10 & 0 & -10\end{array}$ Figure S95: ${ }^{13} \mathrm{C}\left\{{ }^{1} \mathrm{H}\right\} \mathrm{NMR}\left(\mathrm{CDCl}_{3}, 101 \mathrm{MHz}\right)$ of (4-acetylphenyl)(diphenyl) methane (8g) 


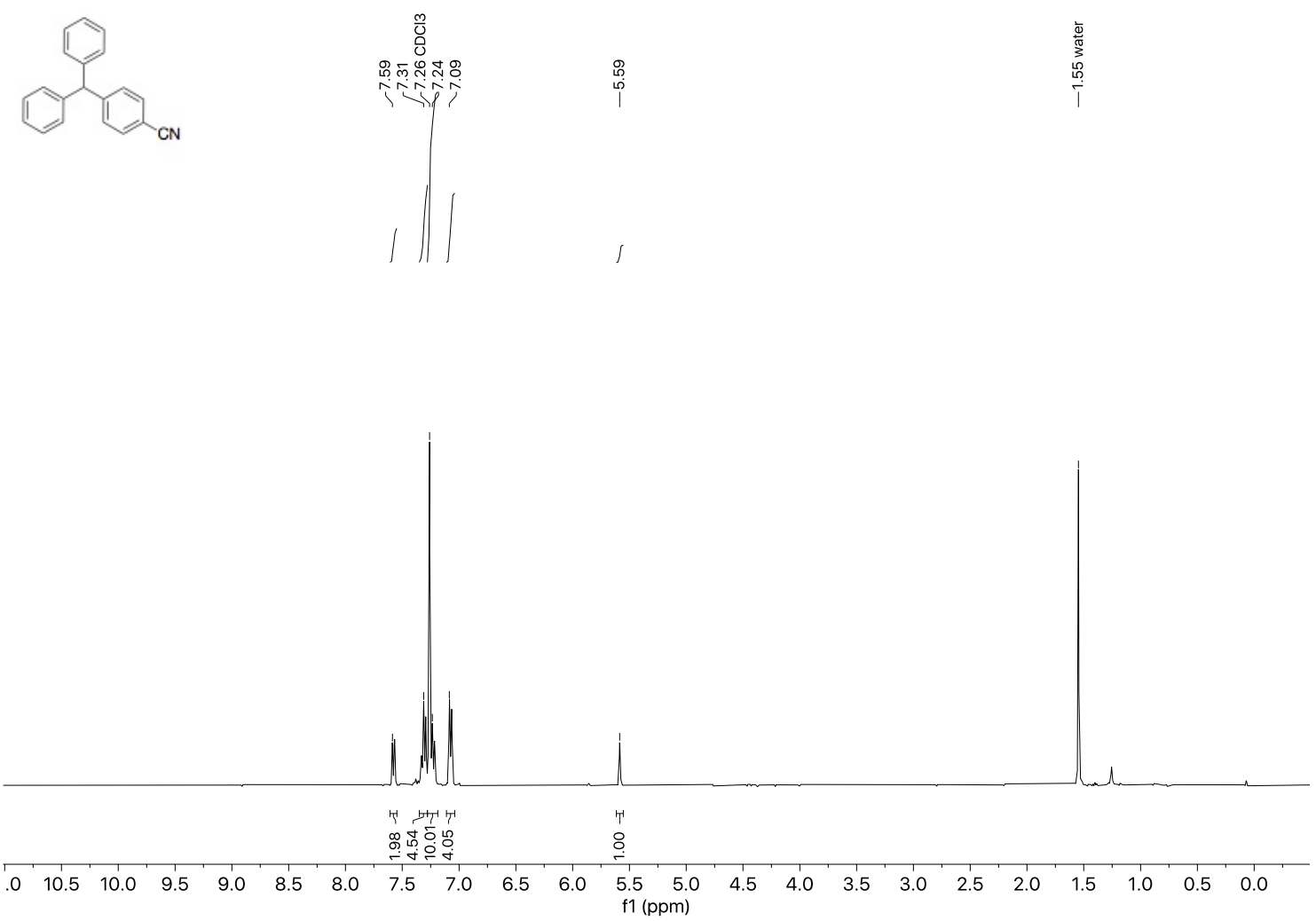

Figure S96: ${ }^{1} \mathrm{H} \mathrm{NMR}\left(\mathrm{CDCl}_{3}, 600 \mathrm{MHz}\right)$ of (4-cyanophenyl)(diphenyl) methane $(\mathbf{8 h})$

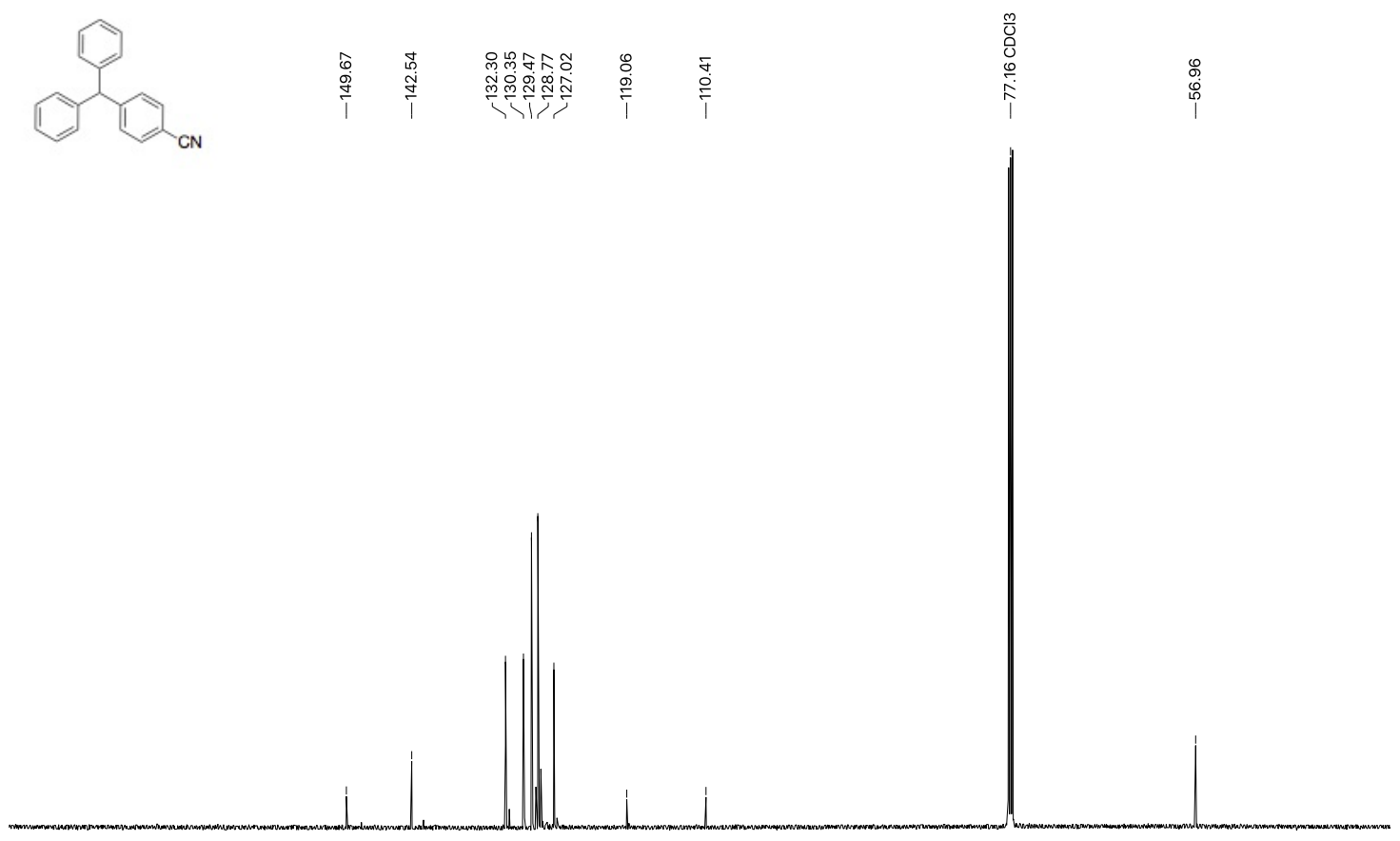

$\begin{array}{lllllllllllllllllllllllllllllllllllllll}185 & 180 & 175 & 170 & 165 & 160 & 155 & 150 & 145 & 140 & 135 & 130 & 125 & 120 & 115 & 110 & 105 & 100 & 95 & 90 & 85 & 80 & 75 & 70 & 65 & 60 & 55 & 50 & 45 & 40\end{array}$

Figure S97: ${ }^{13} \mathrm{C}\left\{{ }^{1} \mathrm{H}\right\} \mathrm{NMR}\left(\mathrm{CDCl}_{3}, 151 \mathrm{MHz}\right)$ of (4-cyanophenyl)(diphenyl) methane (8h) 

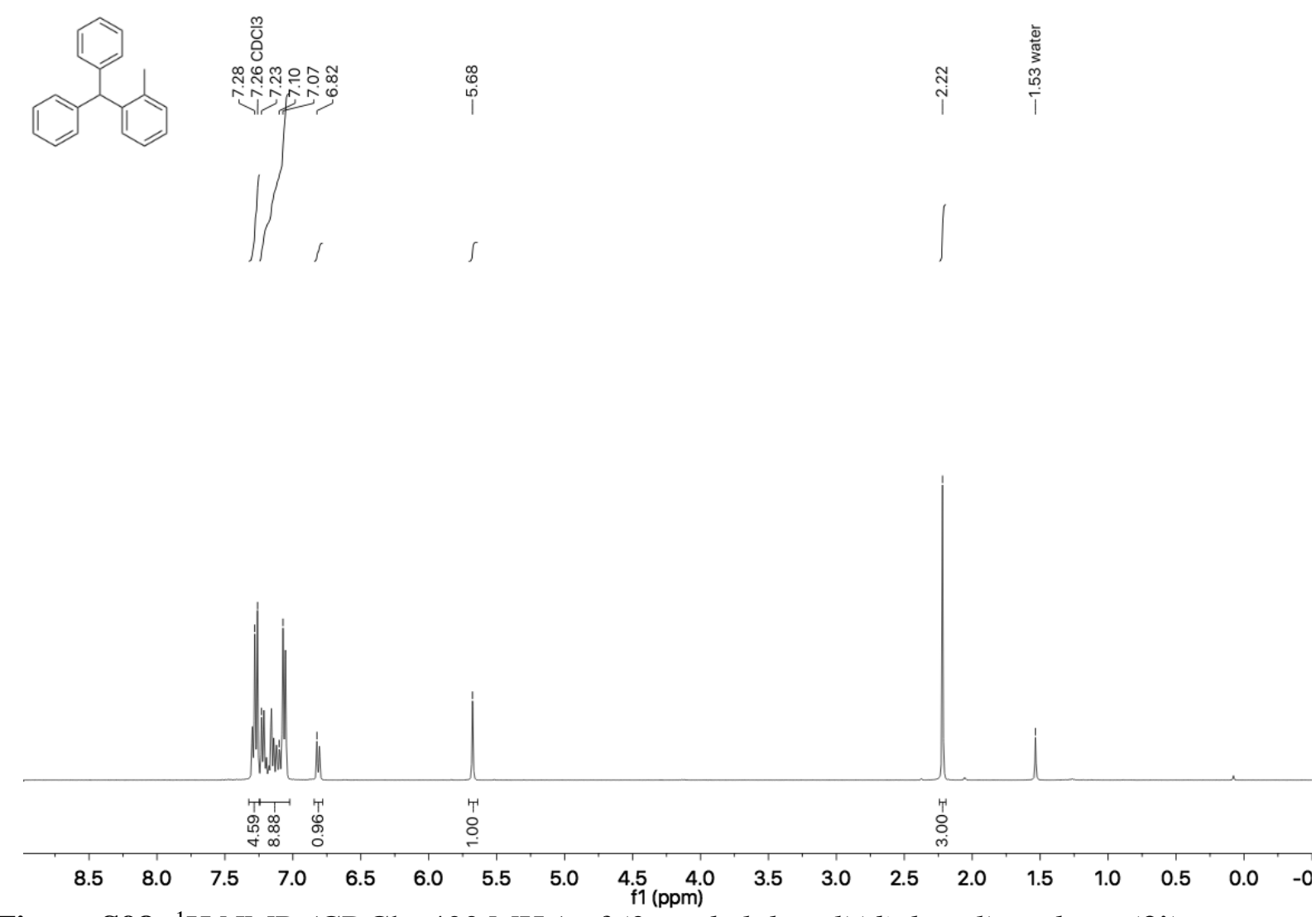

Figure S98: ${ }^{1} \mathrm{H} \mathrm{NMR}\left(\mathrm{CDCl}_{3}, 400 \mathrm{MHz}\right)$ of (2-methylphenyl)(diphenyl) methane (8i)

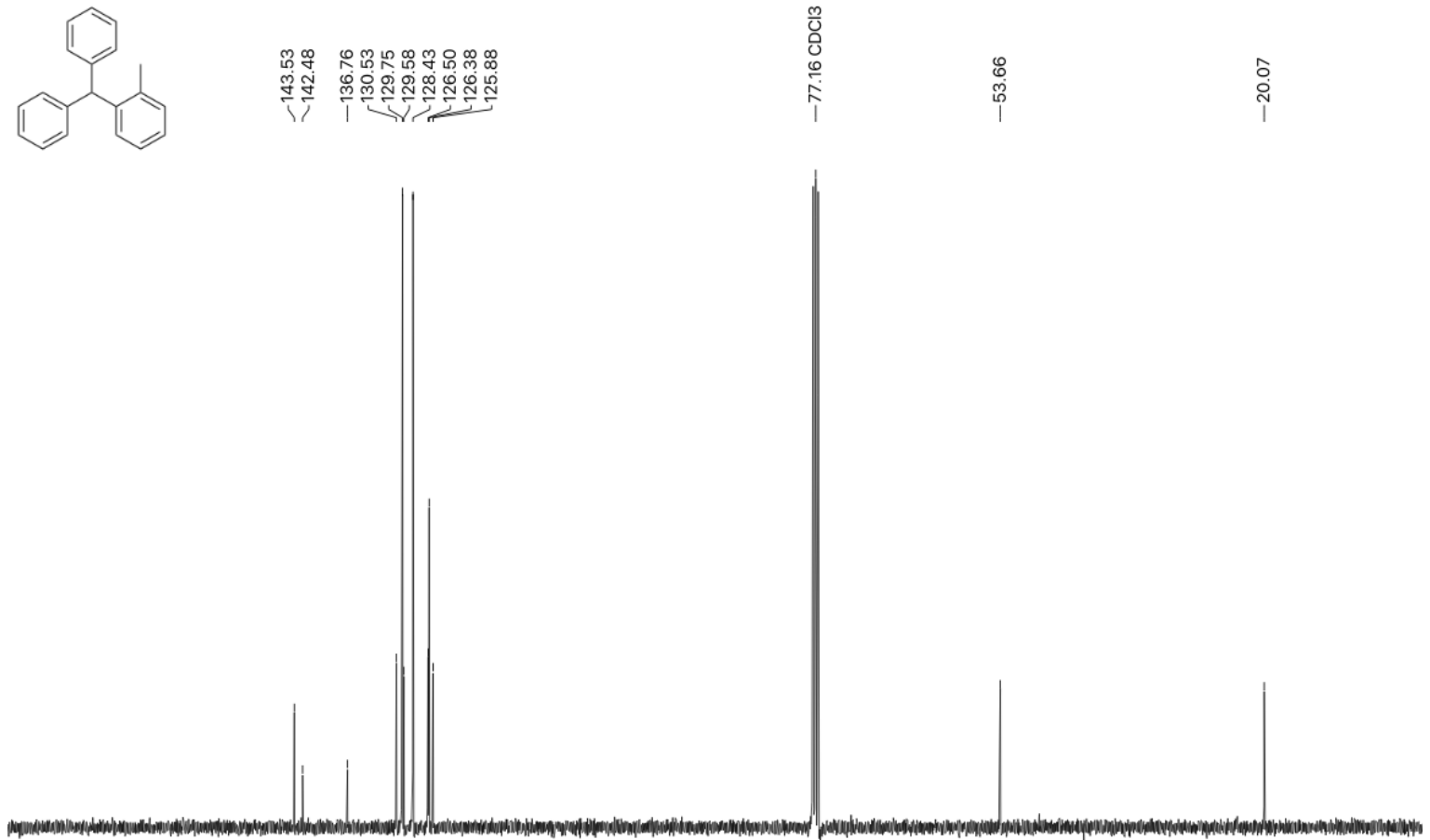

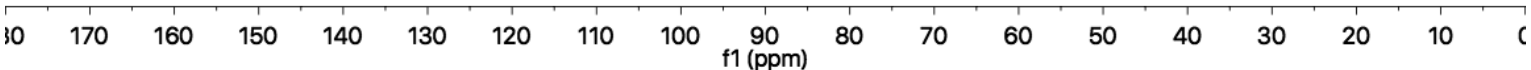

Figure S99: ${ }^{13} \mathrm{C}\left\{{ }^{1} \mathrm{H}\right\} \mathrm{NMR}\left(\mathrm{CDCl}_{3}, 101 \mathrm{MHz}\right)$ of (2-methylphenyl)(diphenyl) methane (8i) 


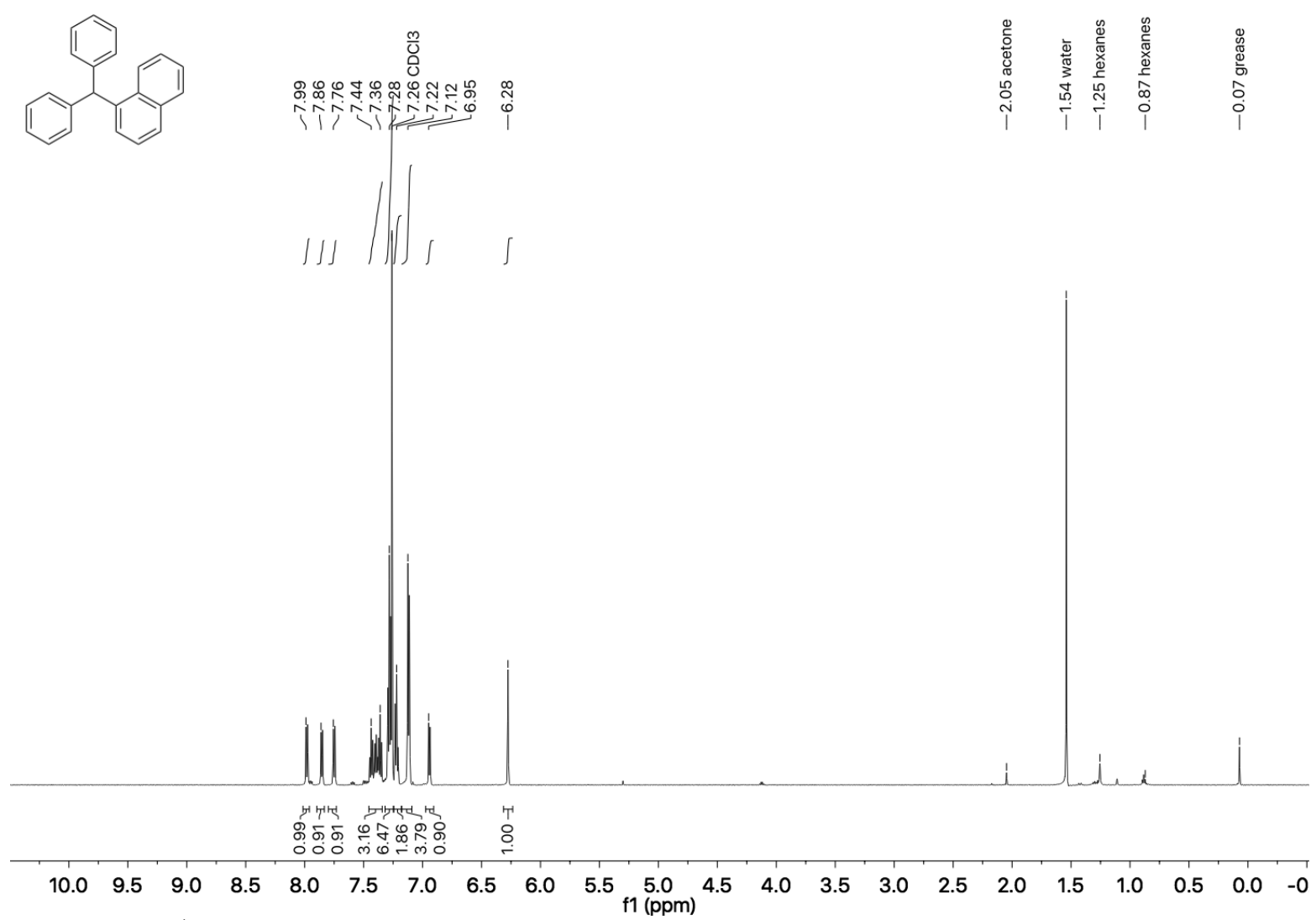

Figure S100: ${ }^{1} \mathrm{H}$ NMR $\left(\mathrm{CDCl}_{3}, 600 \mathrm{MHz}\right)$ of (1-naphthyl)(diphenyl) methane (8j)
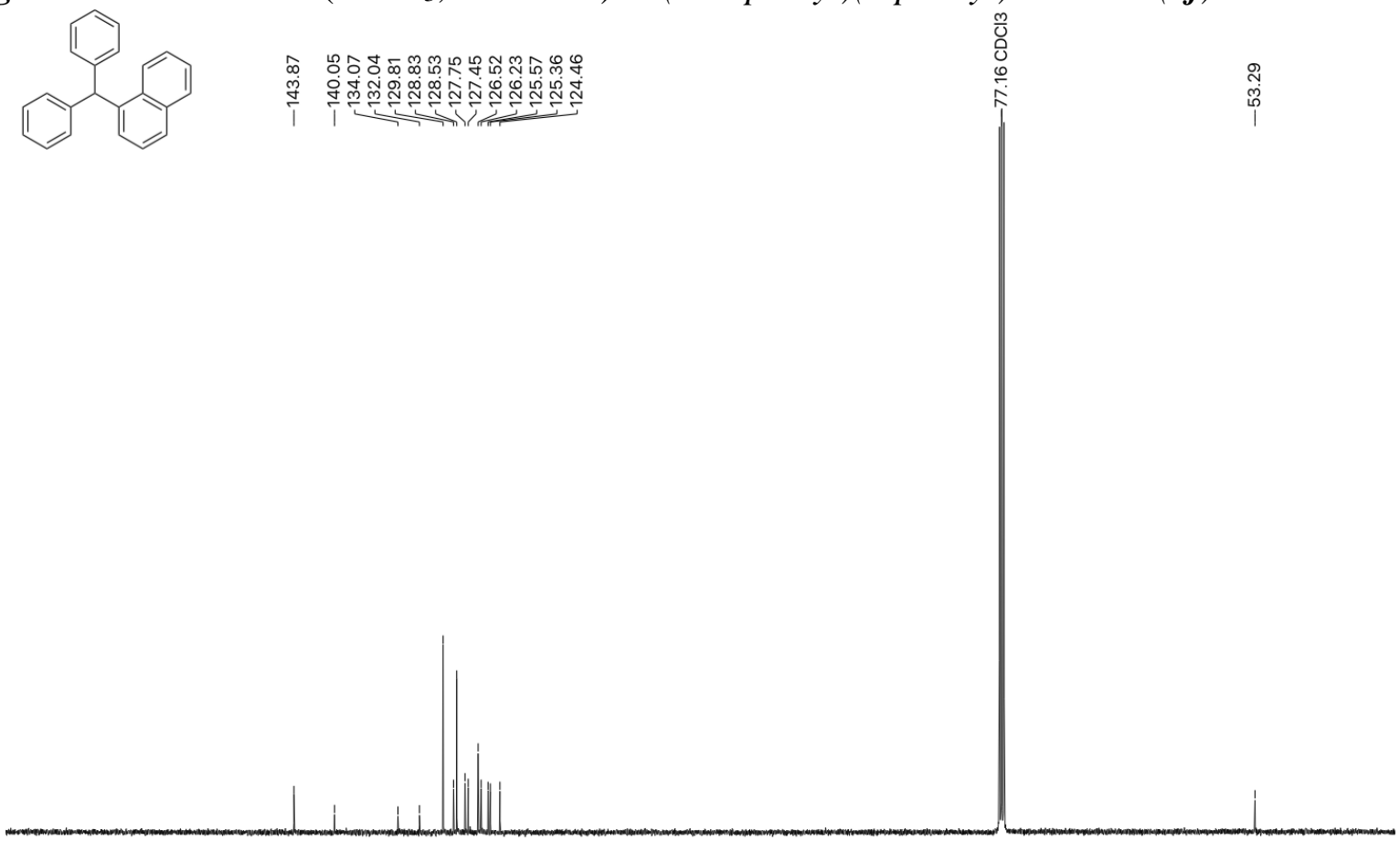

$\begin{array}{lllllllllllllllllllllllllll}70 & 165 & 160 & 155 & 150 & 145 & 140 & 135 & 130 & 125 & 120 & 115 & 110 & 105 & 100 & 95 & 90 & 85 & 80 & 75 & 70 & 65 & 60 & 55 & 50 & 45 & 4\end{array}$ Figure S101: ${ }^{13} \mathrm{C}\left\{{ }^{1} \mathrm{H}\right\} \mathrm{NMR}\left(\mathrm{CDCl}_{3}, 151 \mathrm{MHz}\right)$ of (1-naphthyl)(diphenyl) methane (8j) 


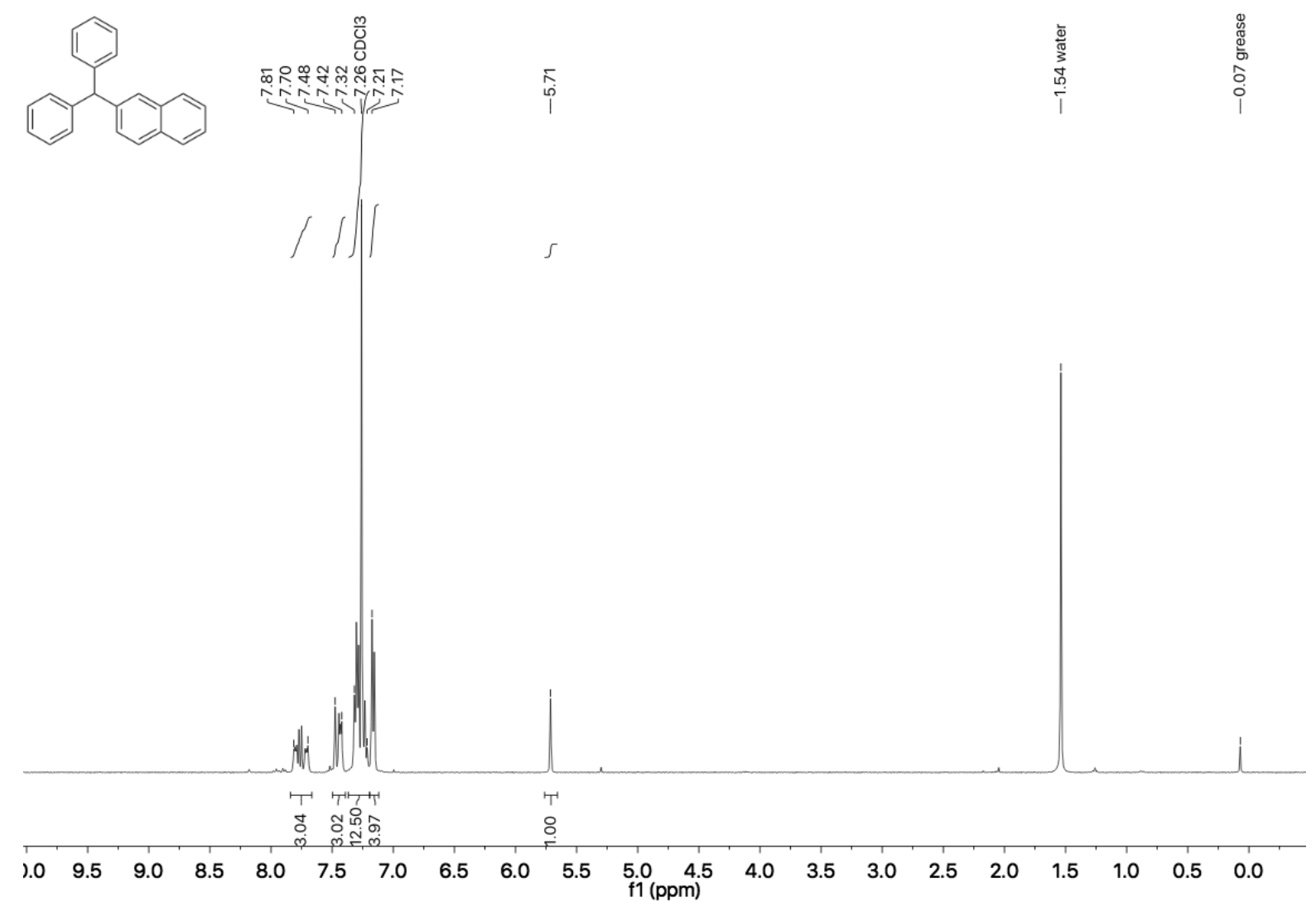

Figure S102: ${ }^{1} \mathrm{H} \mathrm{NMR}\left(\mathrm{CDCl}_{3}, 400 \mathrm{MHz}\right)$ of (2-naphthyl)(diphenyl) methane (8k)

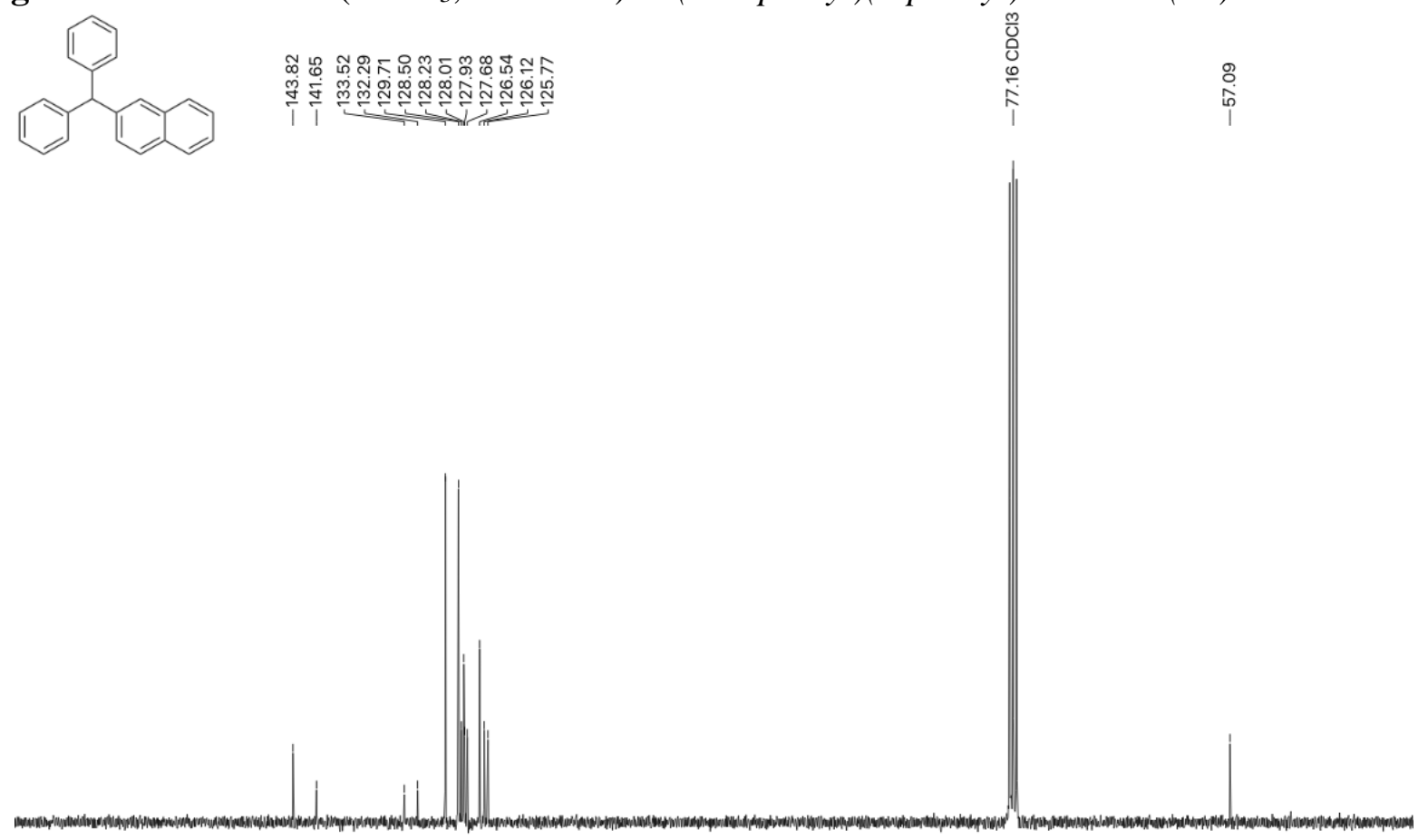

$\begin{array}{lllllllllllllllllllllllll}165 & 160 & 155 & 150 & 145 & 140 & 135 & 130 & 125 & 120 & 115 & 110 \begin{array}{c}105 \\ \mathrm{f} 1(\mathrm{ppm})\end{array} & 100 & 95 & 90 & 85 & 80 & 75 & 70 & 65 & 60 & 55 & 50 & 45 & 4\end{array}$

Figure S103: ${ }^{13} \mathrm{C}\left\{{ }^{1} \mathrm{H}\right\} \mathrm{NMR}\left(\mathrm{CDCl}_{3}, 101 \mathrm{MHz}\right)$ of (2-naphthyl)(diphenyl) methane (8k) 


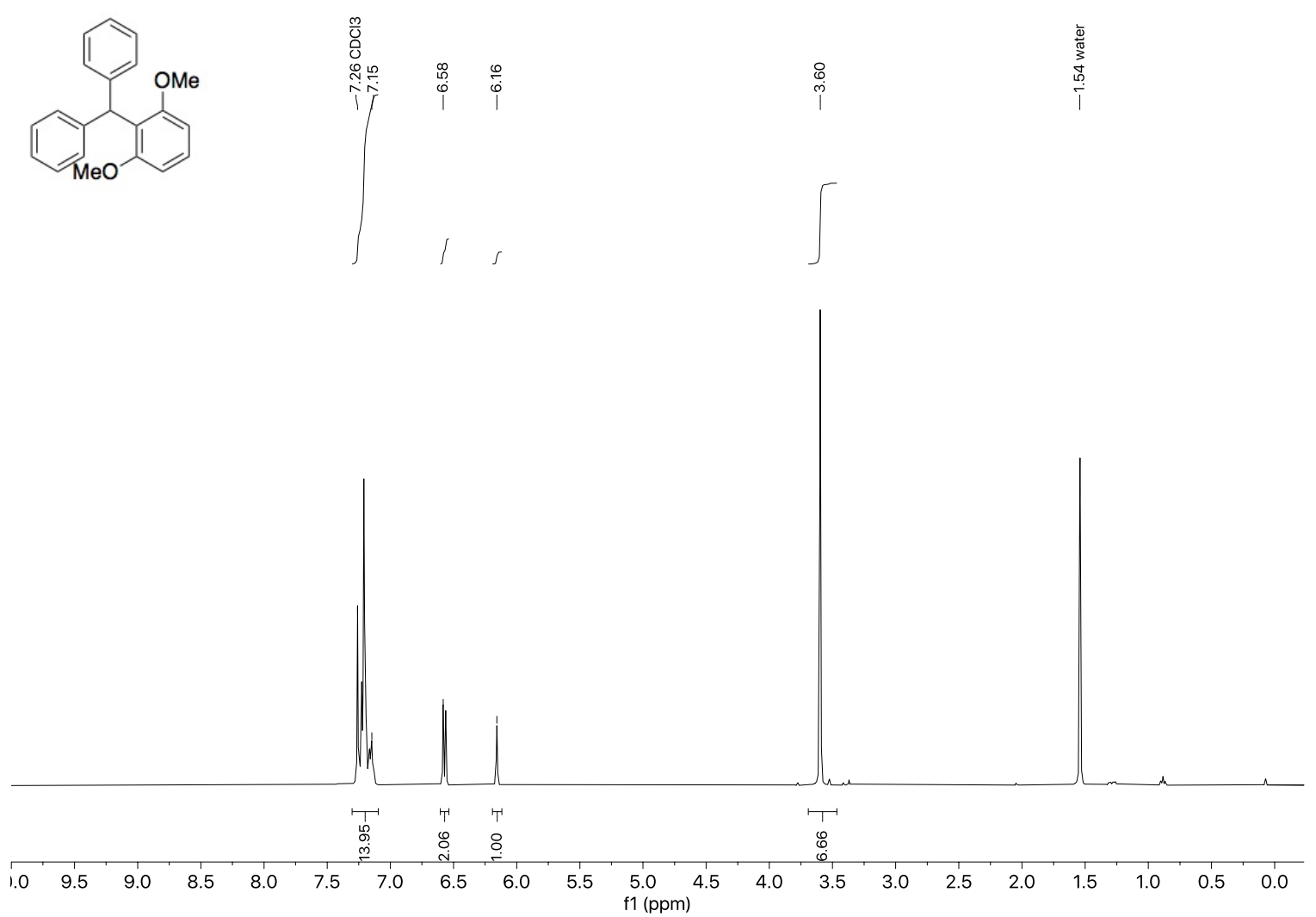

Figure S104: ${ }^{1} \mathrm{H} \mathrm{NMR}\left(\mathrm{CDCl}_{3}, 400 \mathrm{MHz}\right)$ of (2,6-dimethoxyphenyl)(diphenyl) methane (8l) 


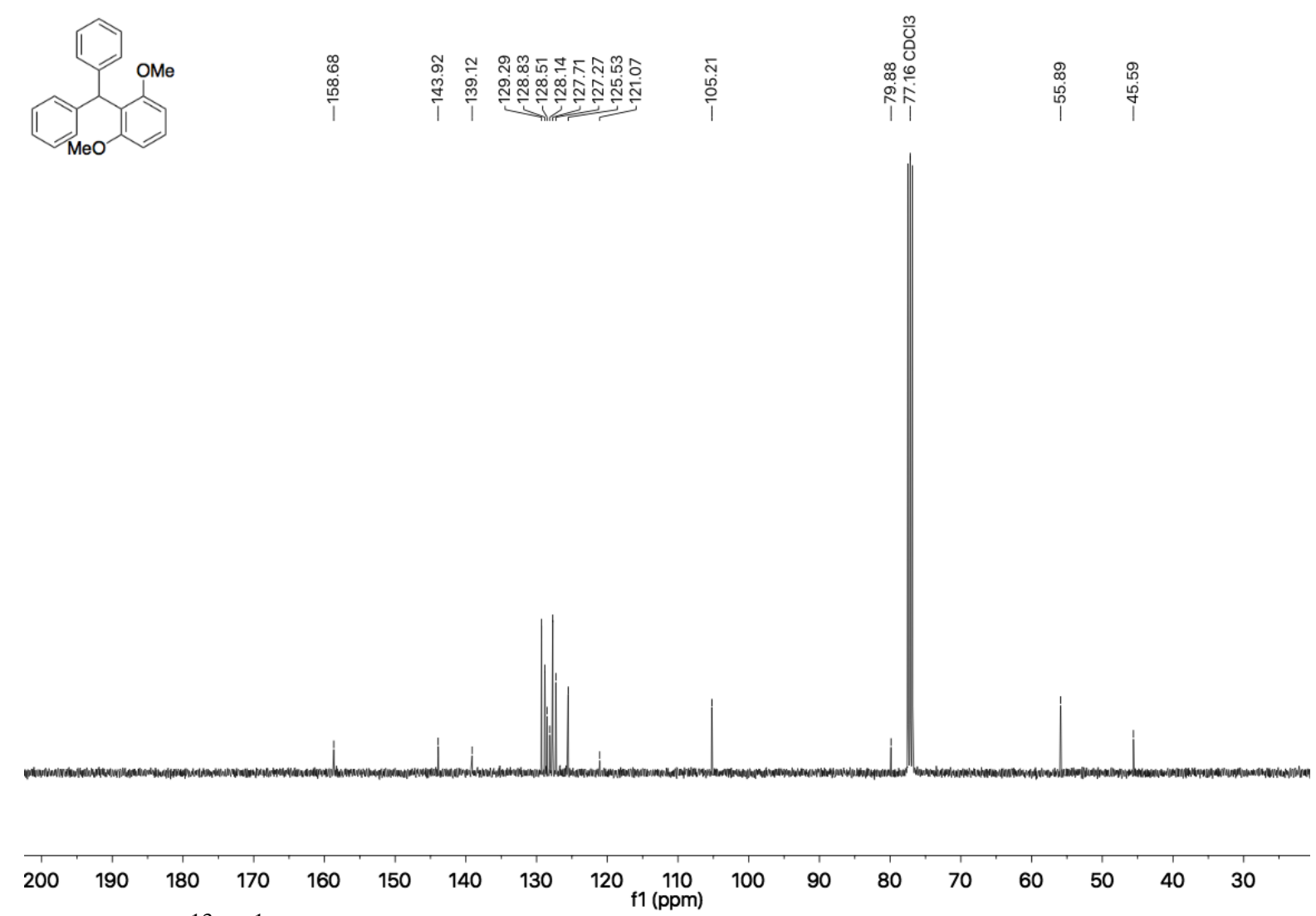

Figure S105: ${ }^{13} \mathrm{C}\left\{{ }^{1} \mathrm{H}\right\} \mathrm{NMR}\left(\mathrm{CDCl}_{3}, 101 \mathrm{MHz}\right)$ of (2,6-dimethoxyphenyl)(diphenyl) methane (8l) 


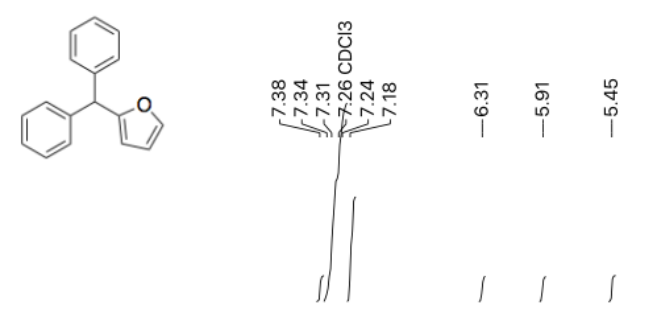

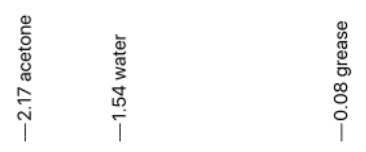

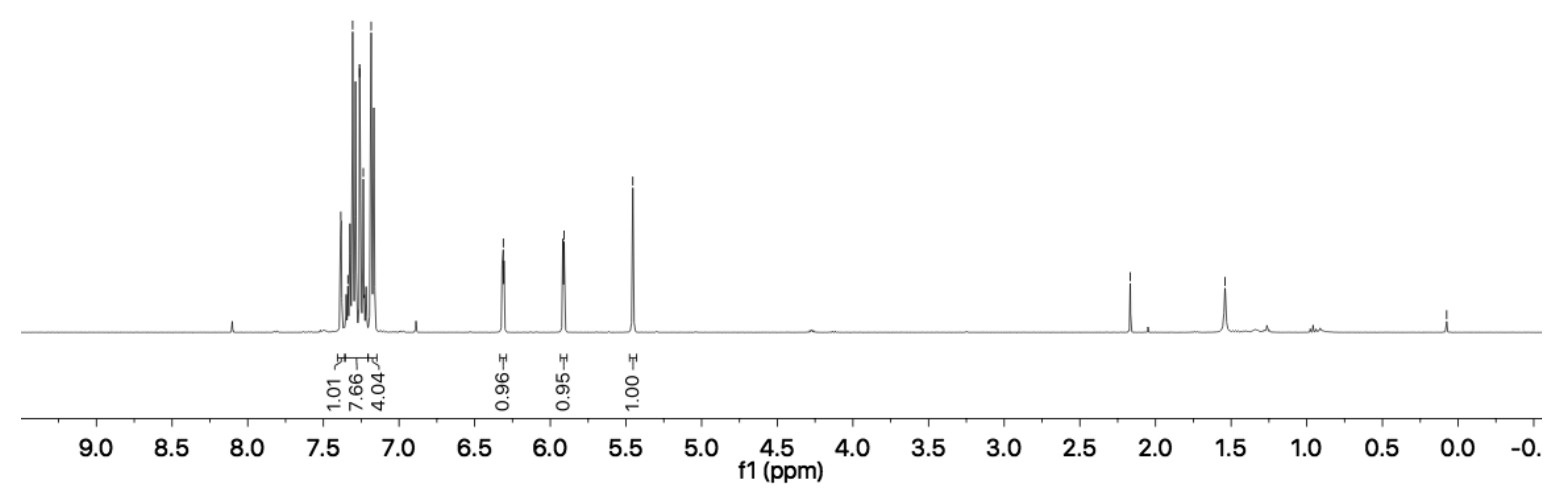

Figure S106: ${ }^{1} \mathrm{H} \mathrm{NMR}\left(\mathrm{CDCl}_{3}, 400 \mathrm{MHz}\right)$ of (2-furyl)(diphenyl) methane $(\mathbf{8 n})$
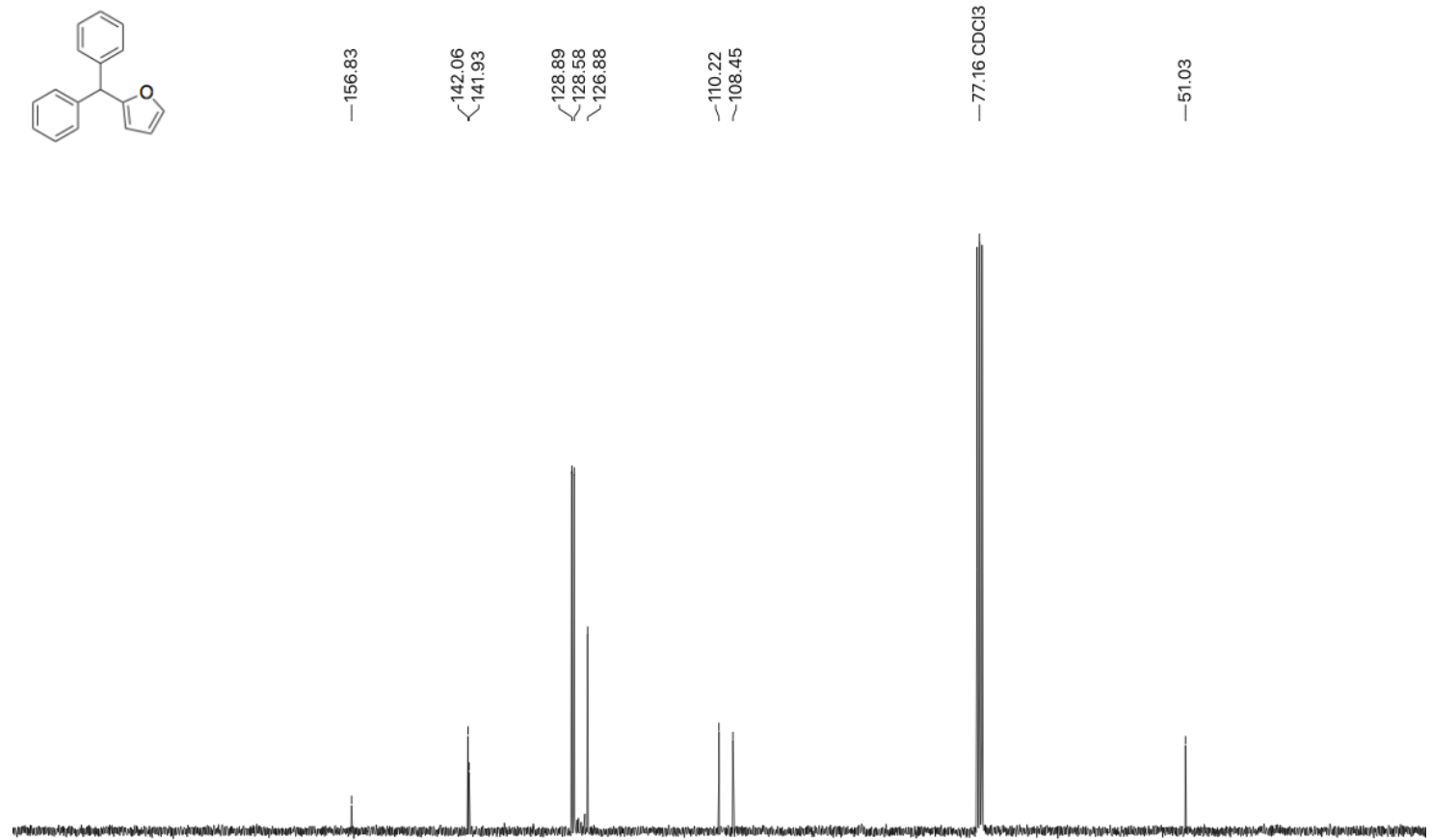

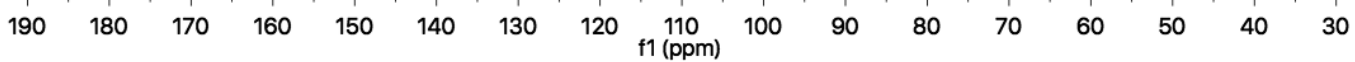

Figure S107: ${ }^{13} \mathrm{C}\left\{{ }^{1} \mathrm{H}\right\} \mathrm{NMR}\left(\mathrm{CDCl}_{3}, 101 \mathrm{MHz}\right)$ of (2-furyl)(diphenyl) methane (8n) 


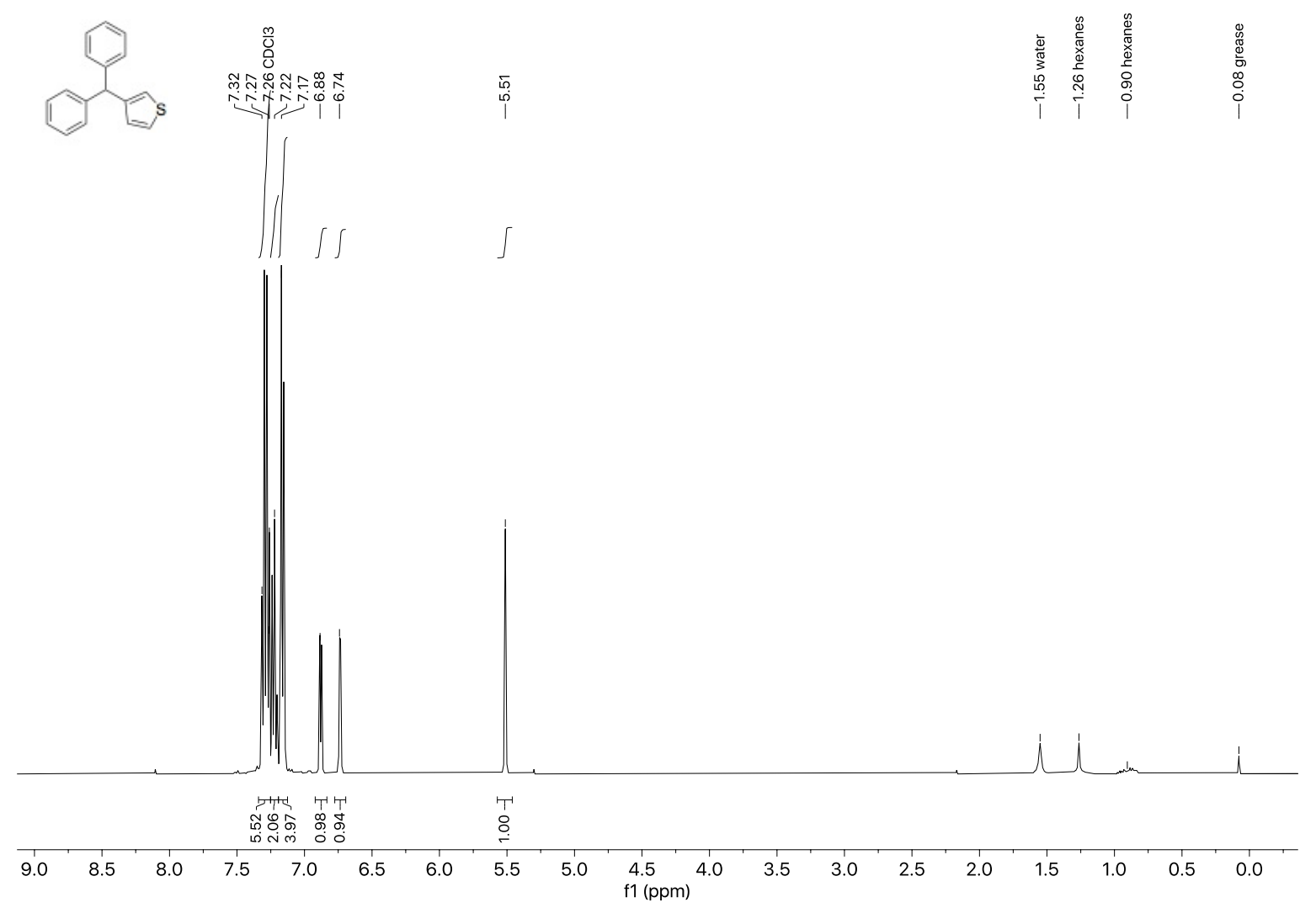

Figure S108: ${ }^{1} \mathrm{H} \mathrm{NMR}\left(\mathrm{CDCl}_{3}, 400 \mathrm{MHz}\right)$ of (3-thienyl)(diphenyl) methane (8o)

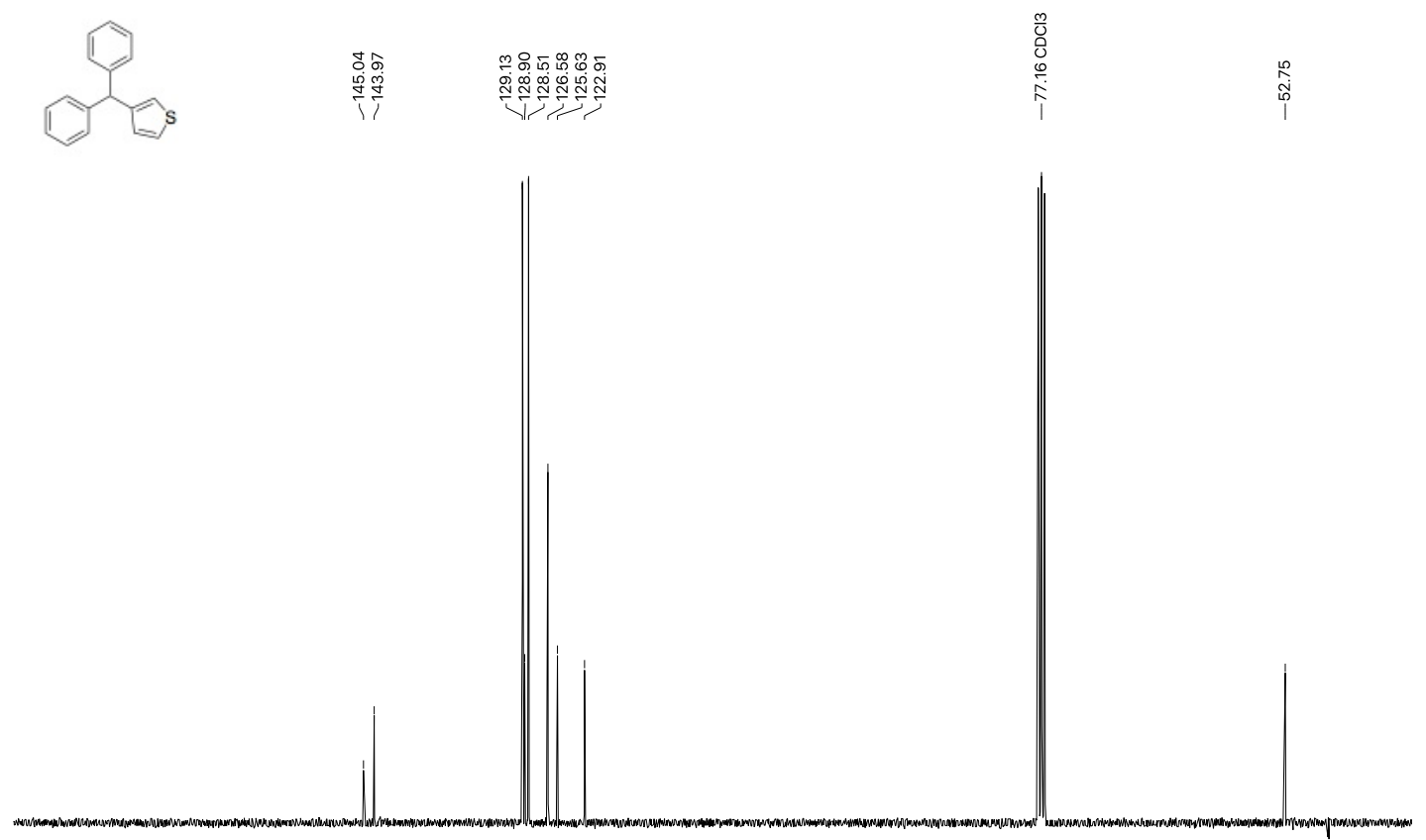

\begin{tabular}{lllllllllllllllllllllllllllllllllllllllll}
\hline 30 & 175 & 170 & 165 & 160 & 155 & 150 & 145 & 140 & 135 & 130 & 125 & 120 & 115 & 110 & 105 & 100 & 95 & 90 & 85 & 80 & 75 & 70 & 65 & 60 & 55 & 50 & 45
\end{tabular}

Figure S109: ${ }^{13} \mathrm{C}\left\{{ }^{1} \mathrm{H}\right\}$ NMR $\left(\mathrm{CDCl}_{3}, 101 \mathrm{MHz}\right)$ of (3-thienyl)(diphenyl) methane $(80)$ 


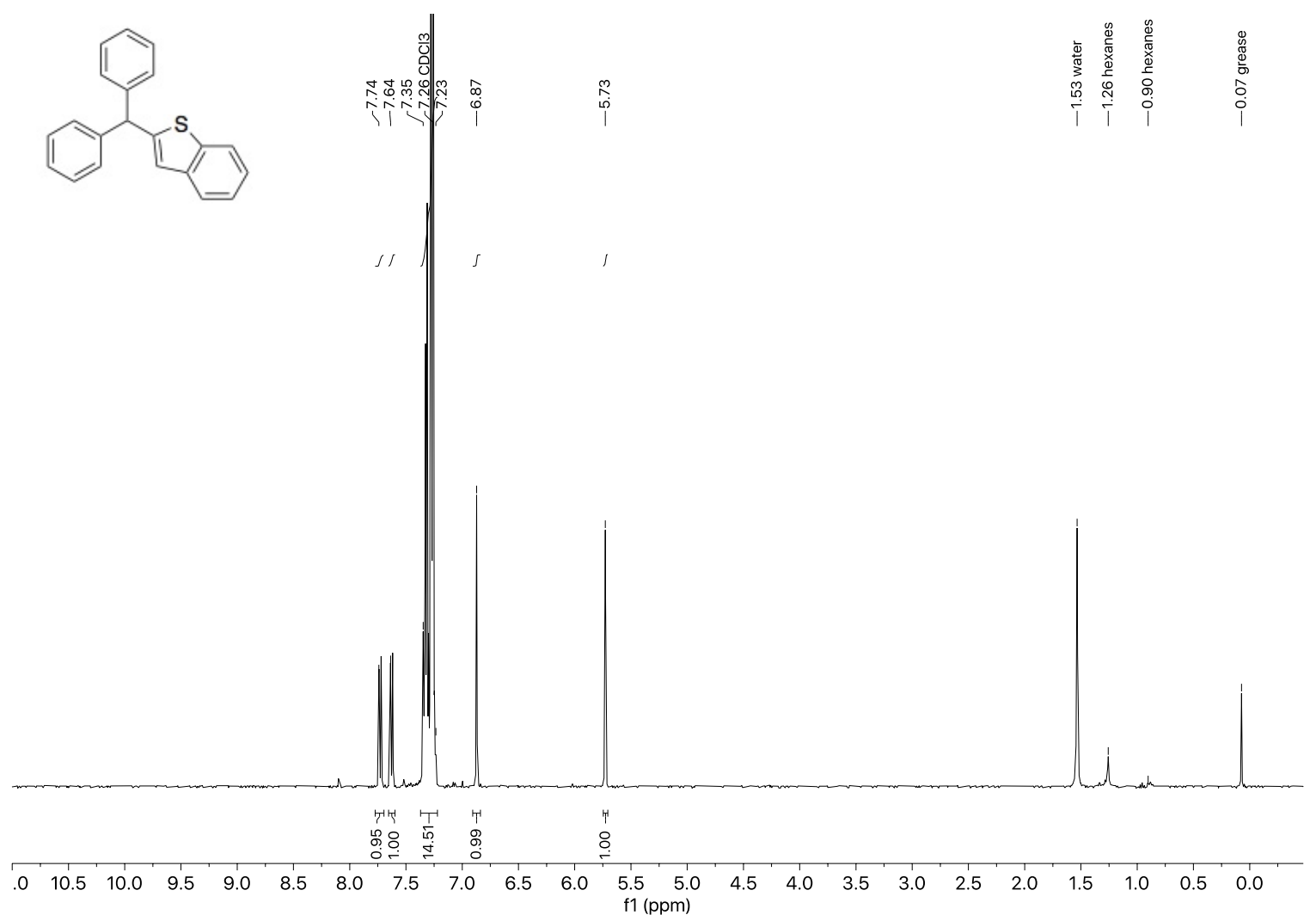

Figure S110: ${ }^{1} \mathrm{H} \mathrm{NMR}\left(\mathrm{CDCl}_{3}, 400 \mathrm{MHz}\right)$ of (2-benzothiophene)(diphenyl) methane (8p)

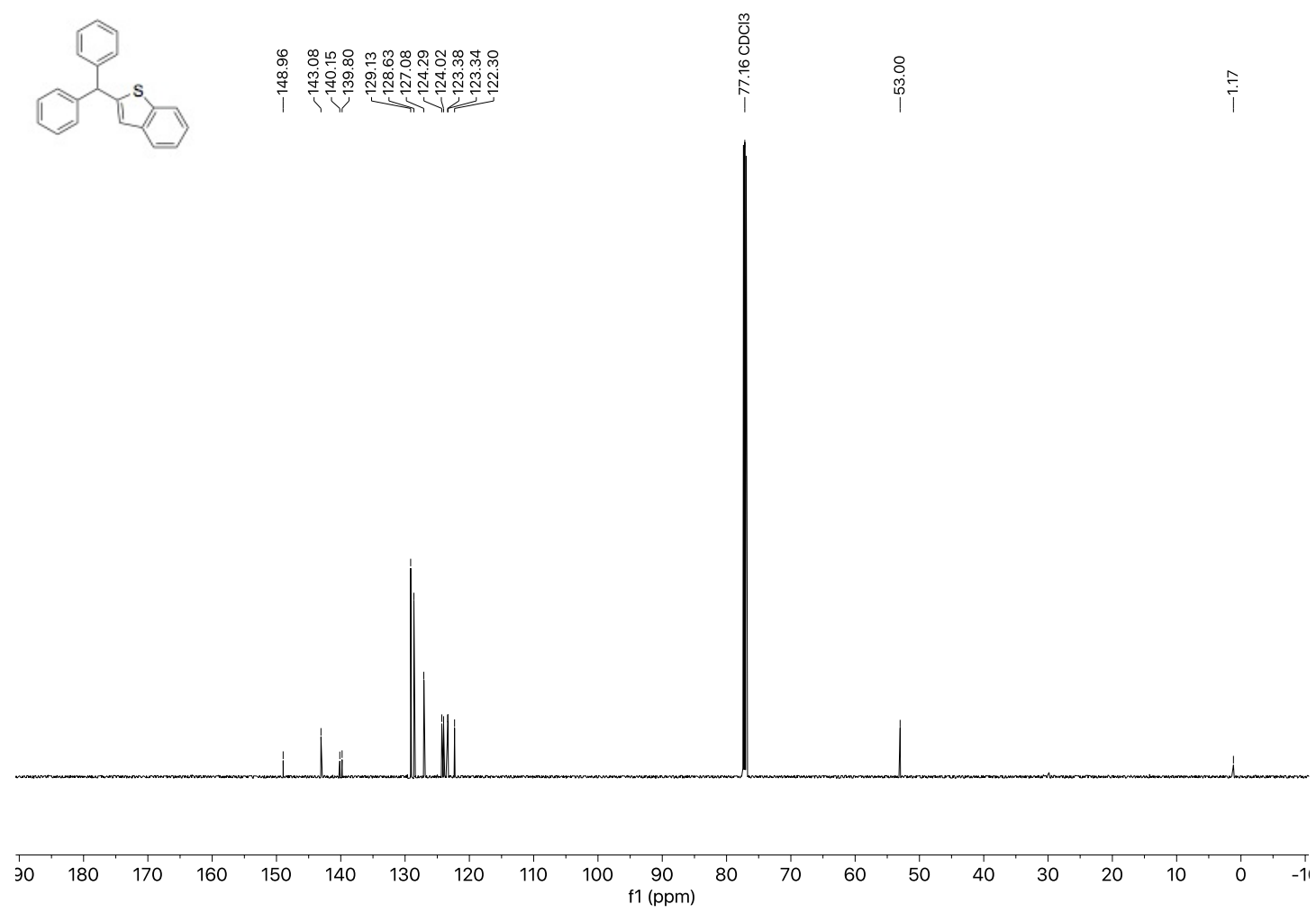

Figure S111: ${ }^{13} \mathrm{C}\left\{{ }^{1} \mathrm{H}\right\} \mathrm{NMR}\left(\mathrm{CDCl}_{3}, 101 \mathrm{MHz}\right)$ of (2-benzothiophene)(diphenyl) methane $(\mathbf{8 p})$ 


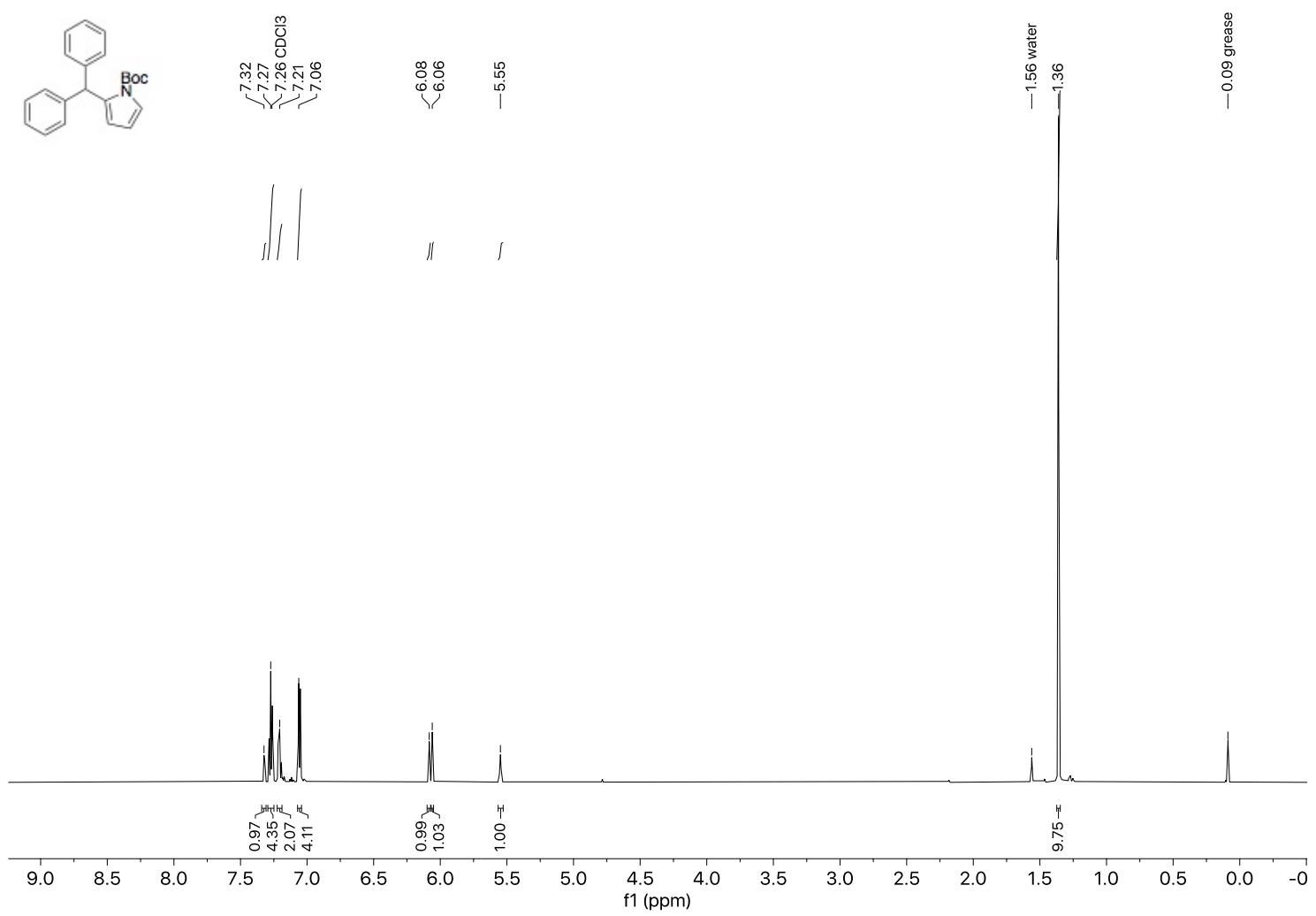

Figure S112: ${ }^{1} \mathrm{H} \mathrm{NMR}\left(\mathrm{CDCl}_{3}, 600 \mathrm{MHz}\right)$ of (2-N-Boc-pyrrole)(diphenyl) methane $(8 q)$
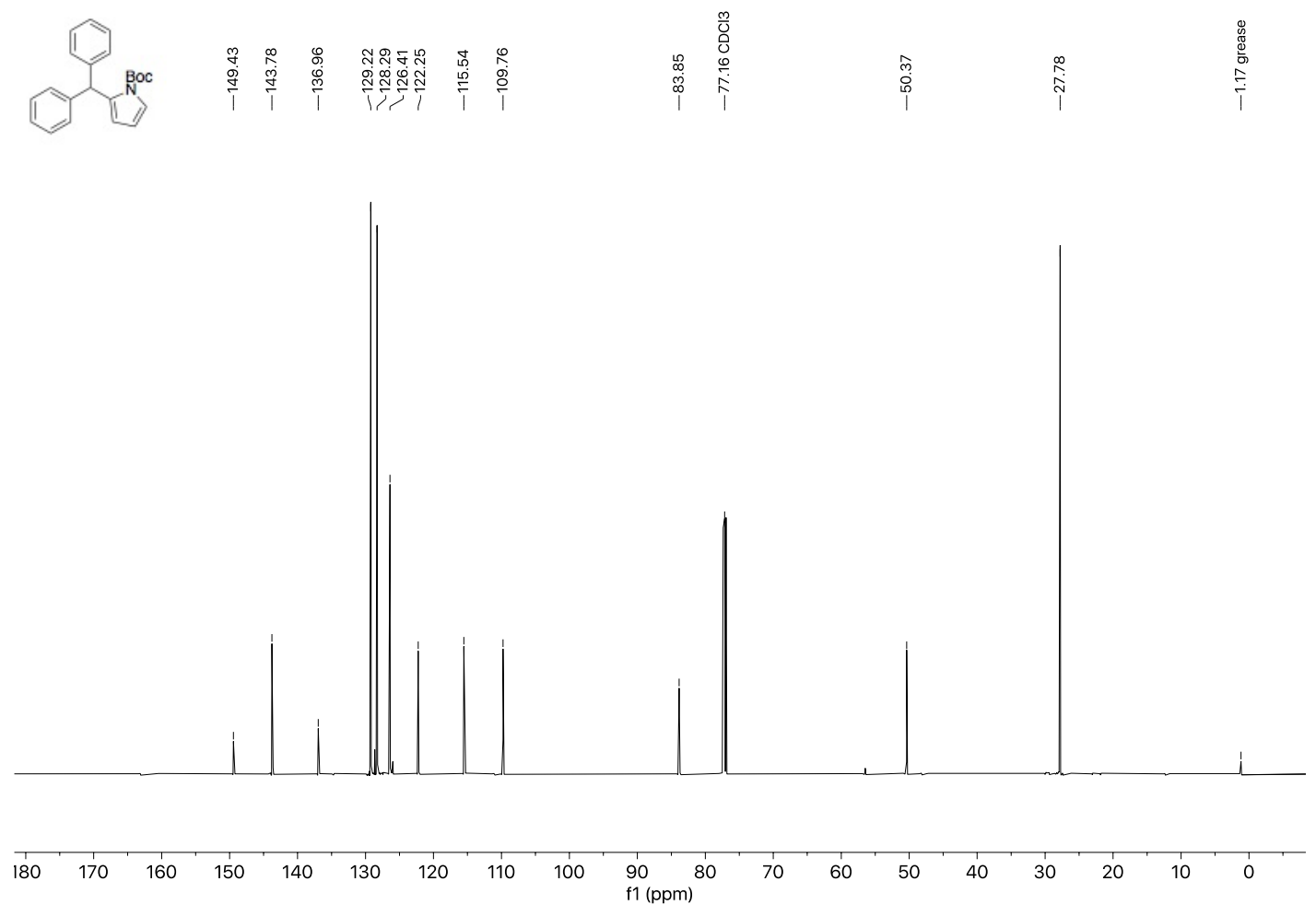

Figure S113: ${ }^{13} \mathrm{C}\left\{{ }^{1} \mathrm{H}\right\}$ NMR $\left(\mathrm{CDCl}_{3}, 151 \mathrm{MHz}\right)$ of (2-N-Boc-pyrrole)(diphenyl) methane (8q) 


\section{XI(C). NMR spectra of palladium complexes}

(IPr)Pd(styrene $)_{2}$
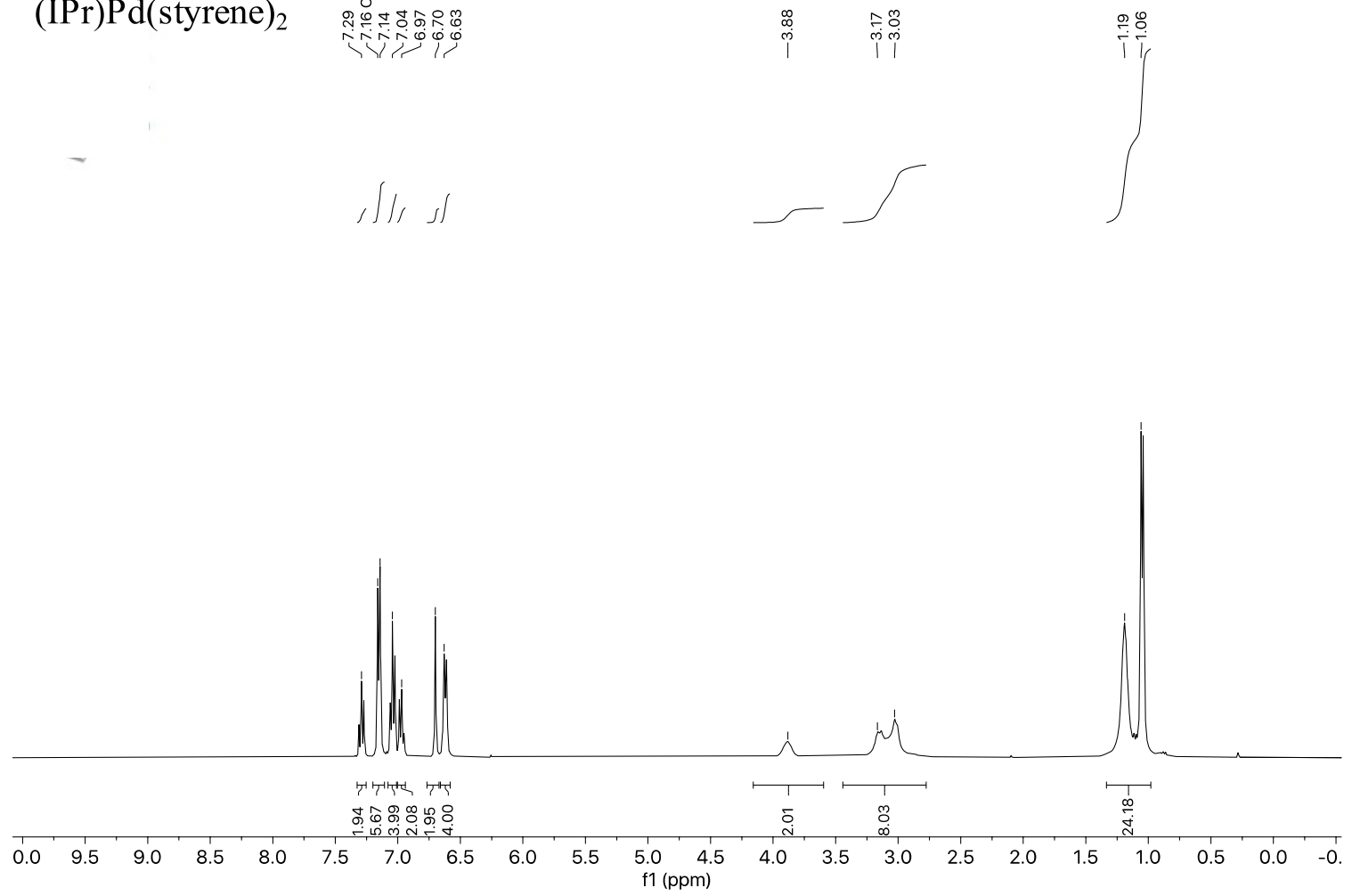

Figure S114: ${ }^{1} \mathrm{H} \mathrm{NMR}\left(\mathrm{CDCl}_{3}, 400 \mathrm{MHz}\right)$ of $(\operatorname{IPr}) \operatorname{Pd}(\text { styrene })_{2}$

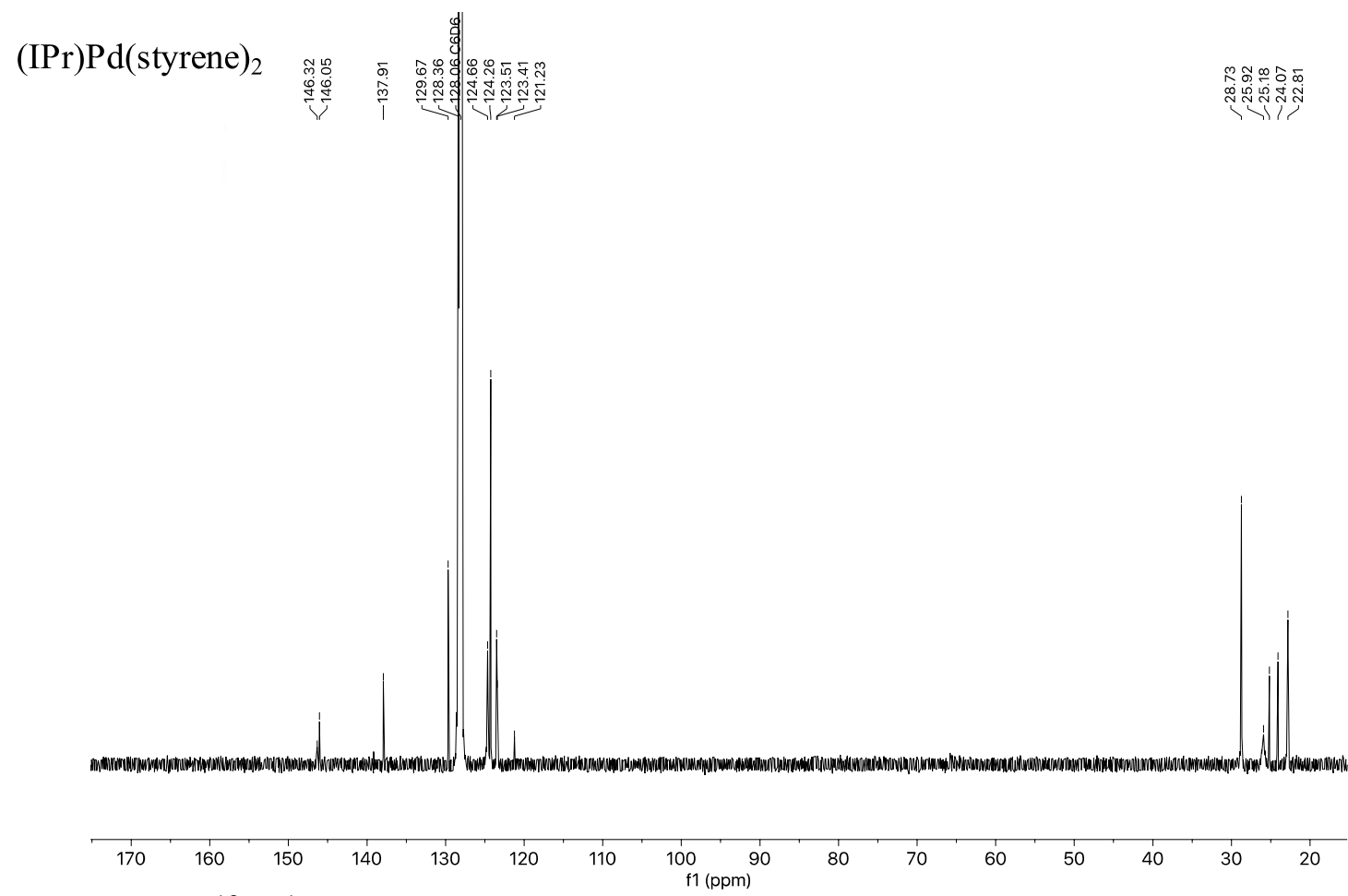

Figure S115: ${ }^{13} \mathrm{C}\left\{{ }^{1} \mathrm{H}\right\}$ NMR $\left(\mathrm{CDCl}_{3}, 101 \mathrm{MHz}\right)$ of $(I P r) P d(\text { styrene })_{2}$ 


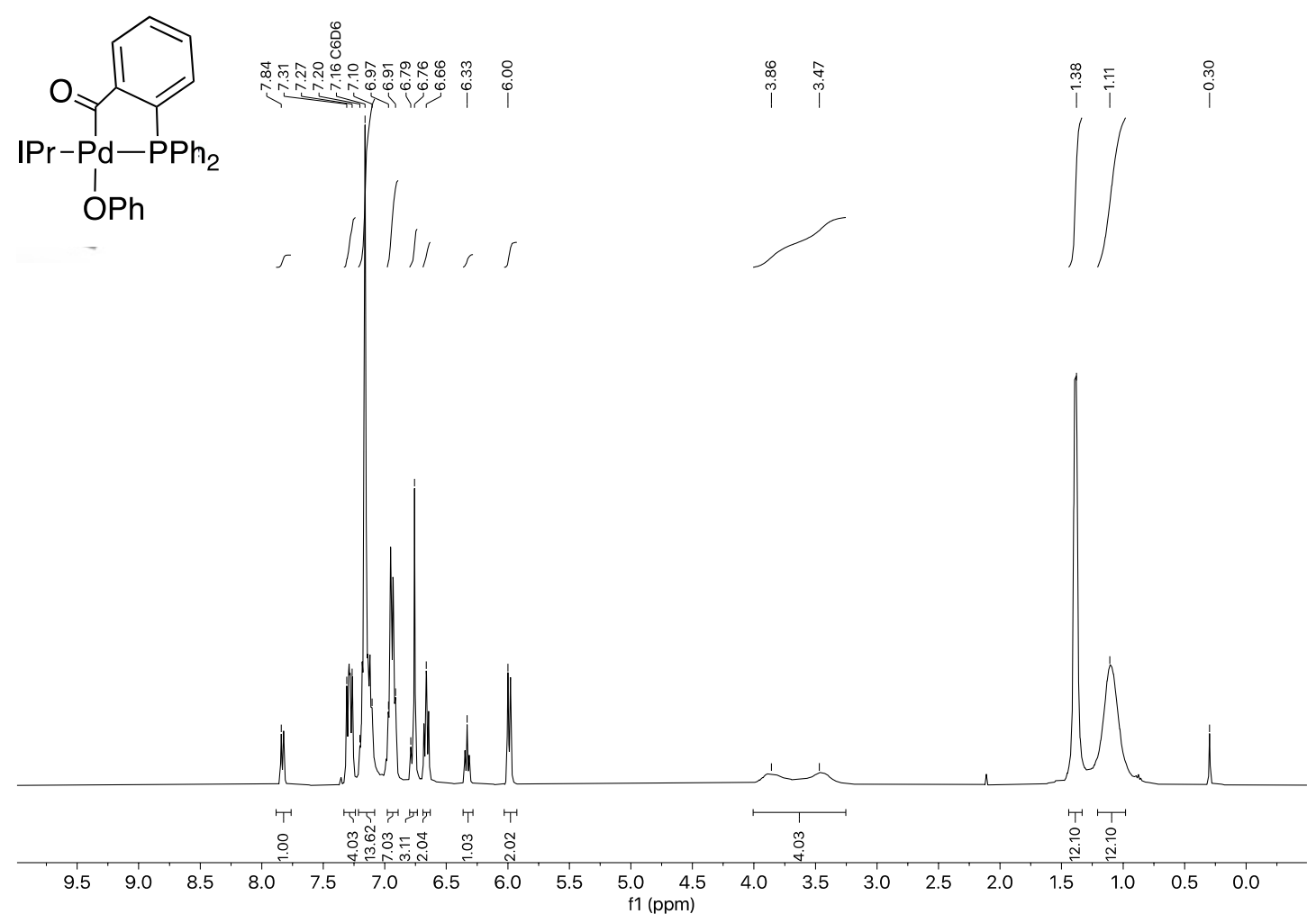

Figure S116: ${ }^{1} \mathrm{H} \mathrm{NMR}\left(\mathrm{CDCl}_{3}, 400 \mathrm{MHz}\right)$ of $(\mathrm{IPr}) \mathrm{Pd}\left(\mathrm{OCC}_{6} \mathrm{H}_{4}\left(2-\mathrm{PPh}_{2}\right)\right)(\mathrm{OPh})($ compound 1) 


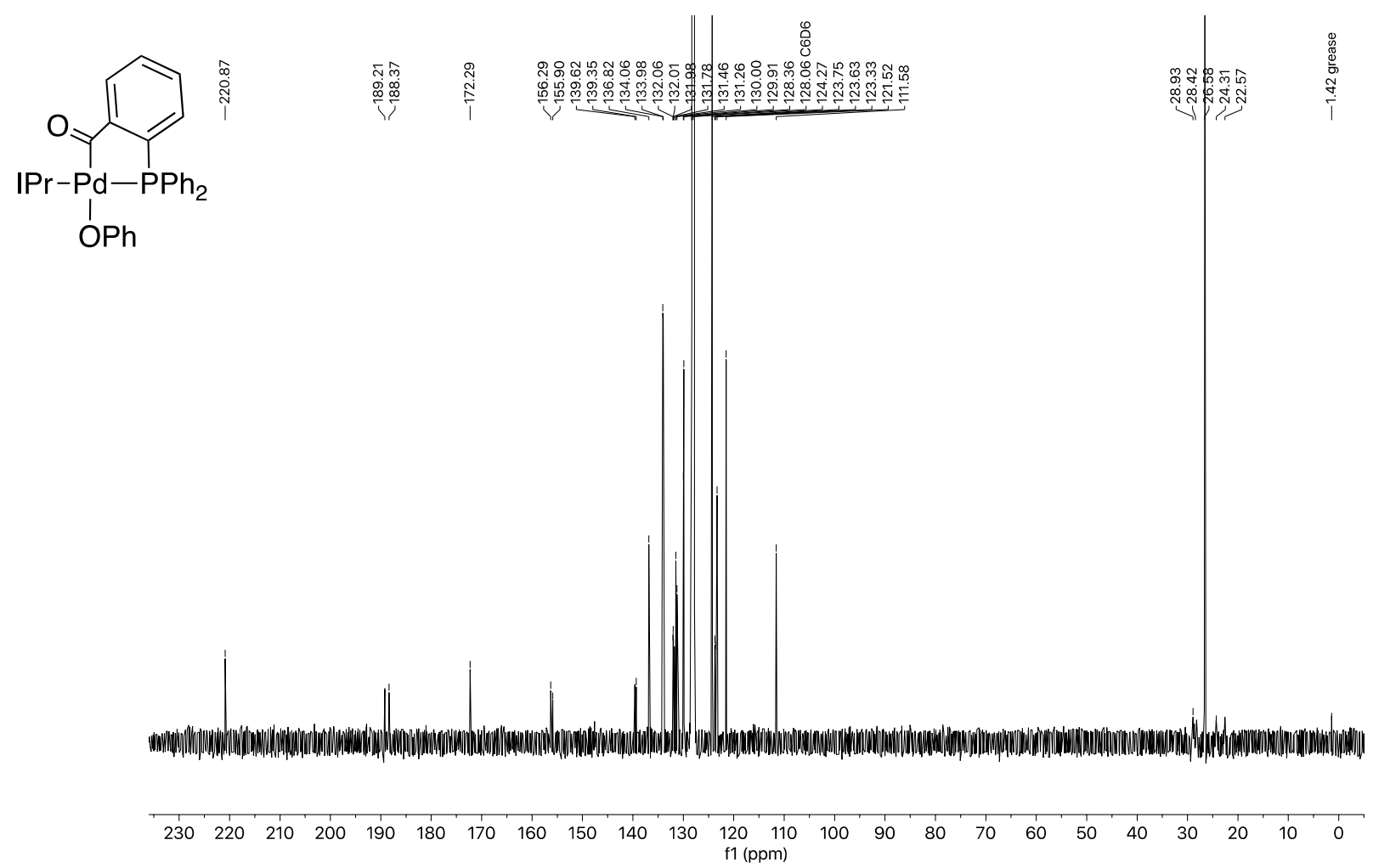

Figure S117: ${ }^{13} \mathrm{C}\left\{{ }^{1} \mathrm{H}\right\} \mathrm{NMR}\left(\mathrm{CDCl}_{3}, 101 \mathrm{MHz}\right)$ of $(\mathrm{IPr}) \mathrm{Pd}\left(\mathrm{OCC}_{6} \mathrm{H}_{4}\left(2-\mathrm{PPh}_{2}\right)\right)(\mathrm{OPh})($ compound 1) 


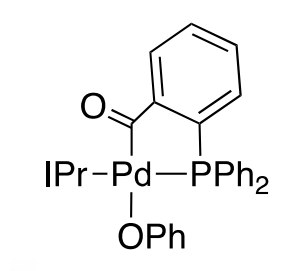

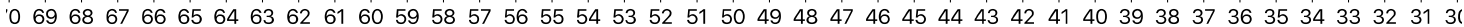
f1 (ppm)

Figure S118: ${ }^{31} \mathrm{P}\left\{{ }^{1} \mathrm{H}\right\} \mathrm{NMR}\left(\mathrm{CDCl}_{3}, 121, \mathrm{MHz}\right)$ of $(\operatorname{IPr}) \operatorname{Pd}\left(O C C_{6} H_{4}\left(2-P P h_{2}\right)\right)(O P h)($ compound 1) 


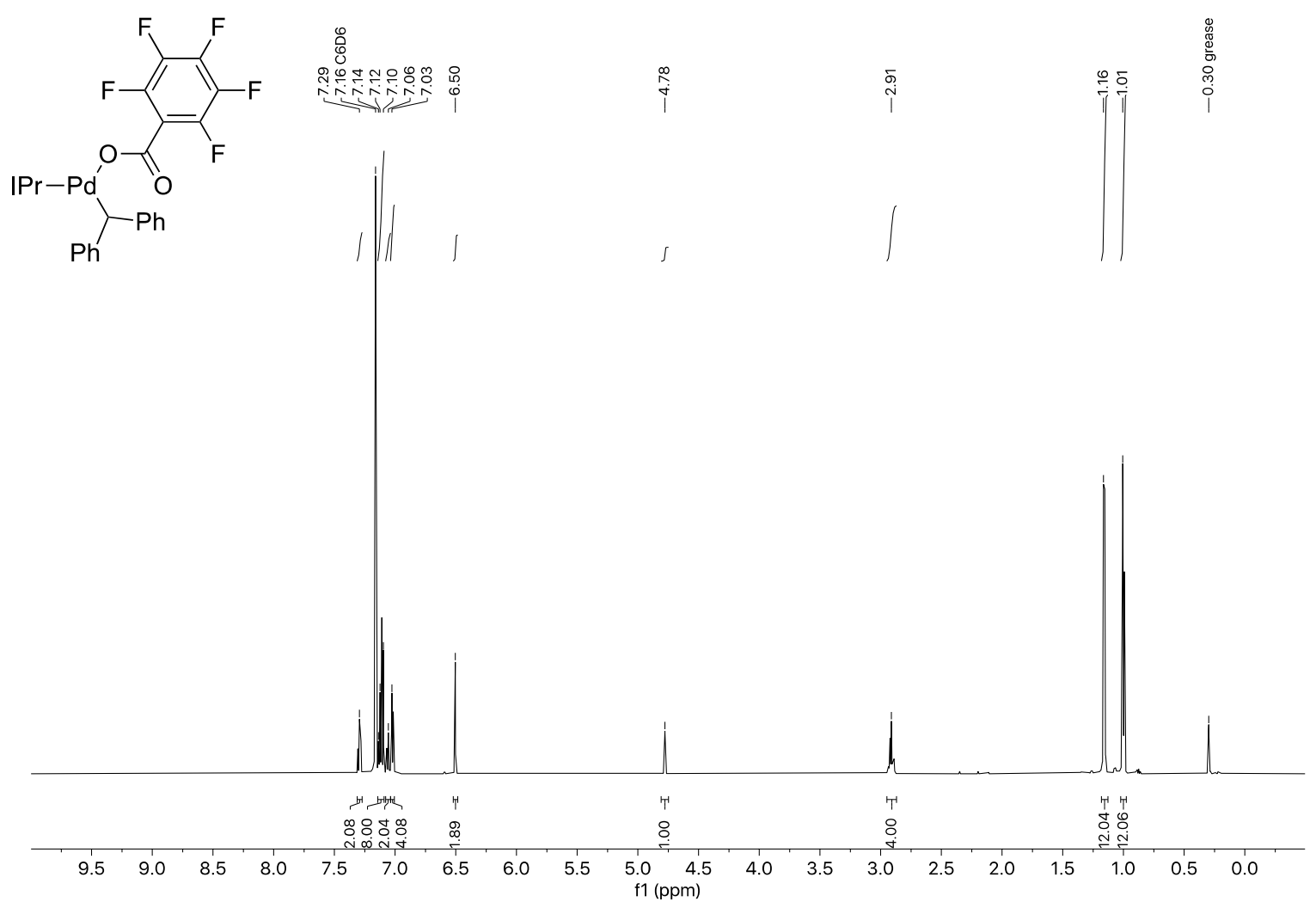

Figure S119: ${ }^{1} \mathrm{H} \mathrm{NMR}\left(\mathrm{CDCl}_{3}, 600 \mathrm{MHz}\right)$ of $(\mathrm{IPr}) \mathrm{Pd}\left(\mathrm{OOCC}_{6} \mathrm{~F}_{5}\right)\left(\mathrm{CHPh}_{2}\right)($ compound 2)
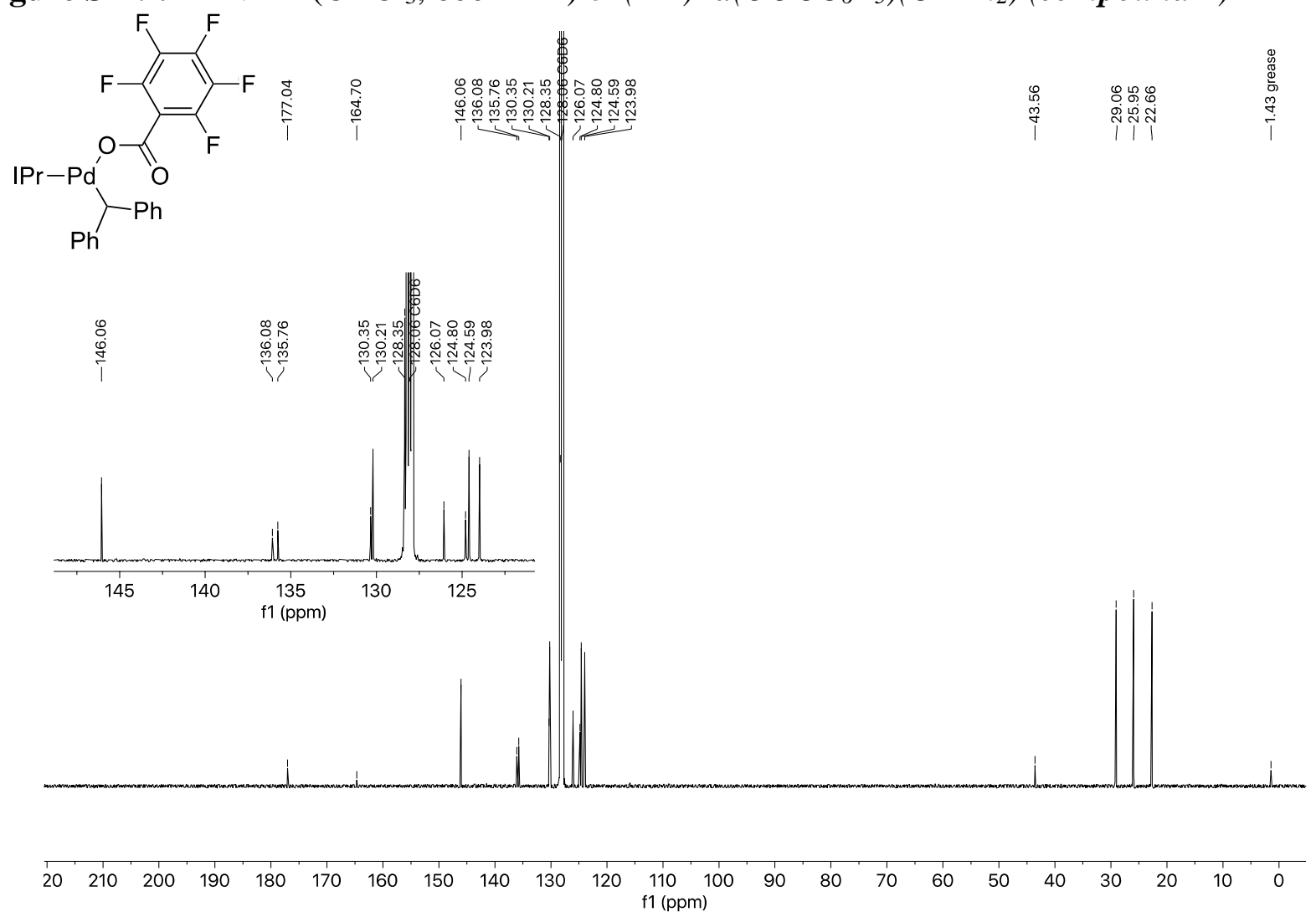

Figure S120: ${ }^{13} \mathrm{C}\left\{{ }^{1} \mathrm{H}\right\} \mathrm{NMR}\left(\mathrm{CDCl}_{3}, 151 \mathrm{MHz}\right)$ of $(\mathrm{IPr}) \mathrm{Pd}\left(\mathrm{OOCC}_{6} \mathrm{~F}_{5}\right)\left(\mathrm{CHPh}_{2}\right)$ (compound 2) 


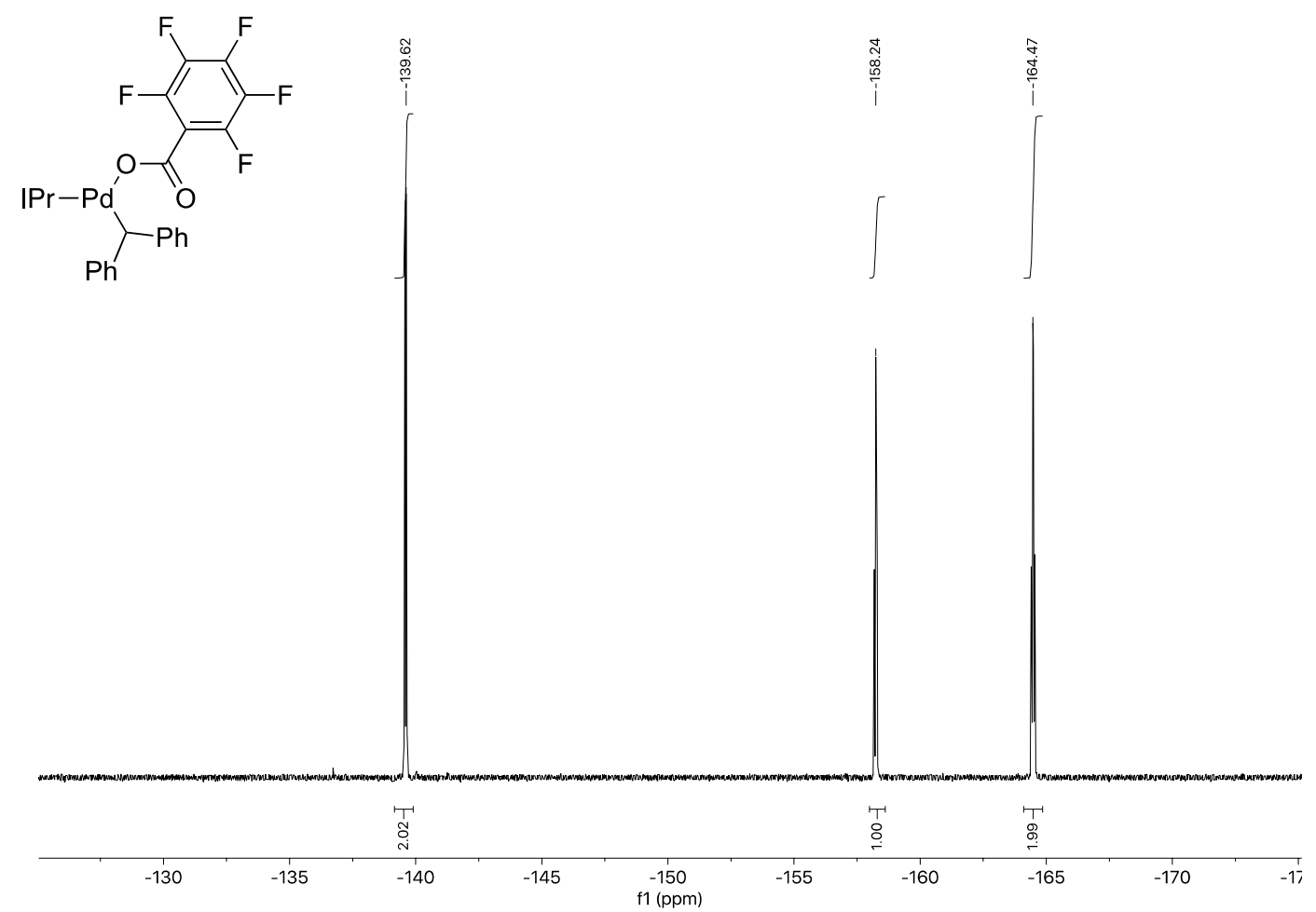

Figure S121: ${ }^{19} \mathrm{~F} \mathrm{NMR}\left(\mathrm{CDCl}_{3}, 376 \mathrm{MHz}\right)$ of $(\mathrm{IPr}) \mathrm{Pd}\left(\mathrm{OOCC}_{6} \mathrm{~F}_{5}\right)\left(\mathrm{CHPh}_{2}\right)($ compound 2) 


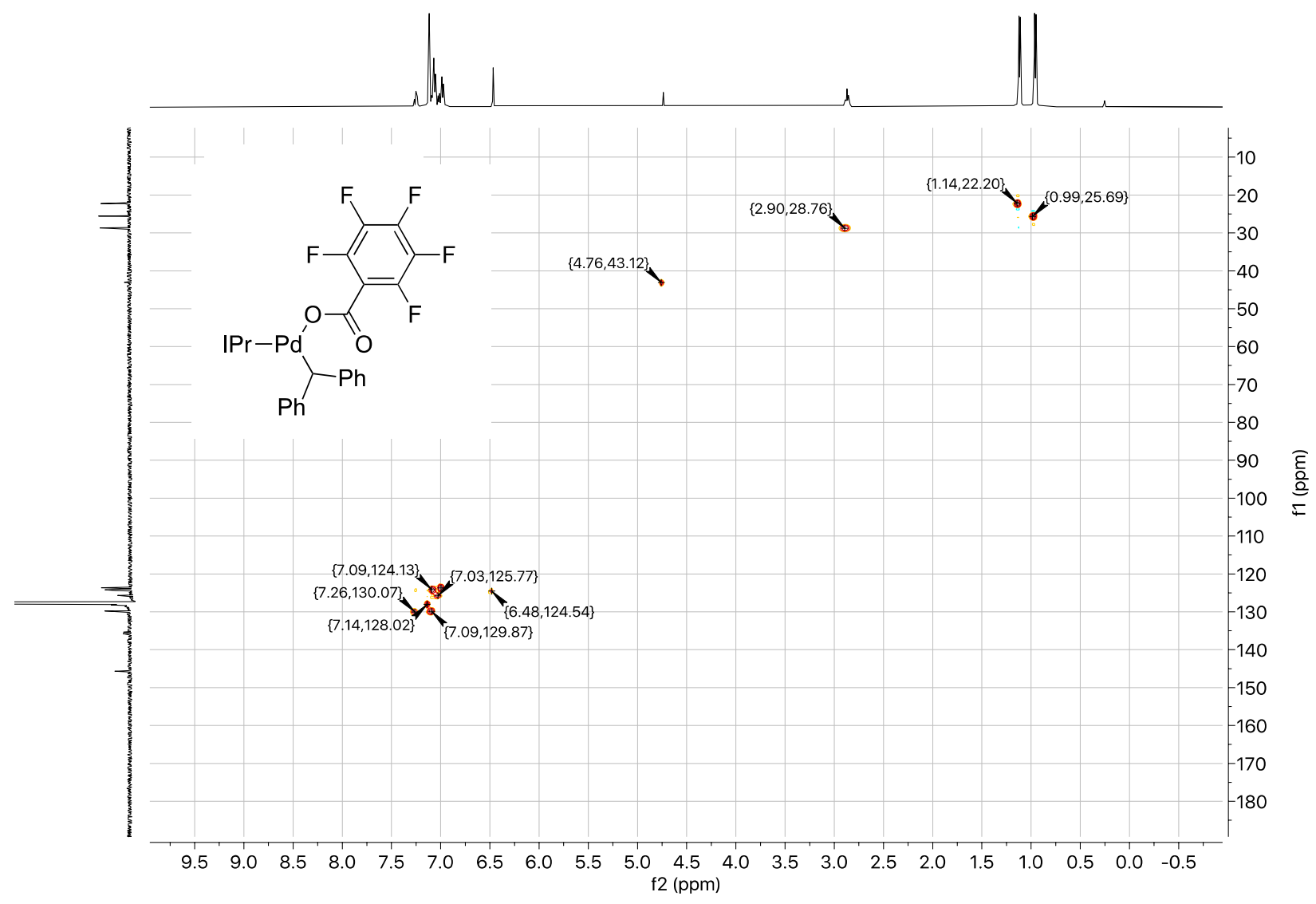

Figure S122: ${ }^{1} \mathrm{H} \quad \mathrm{NMR} \quad\left(\mathrm{CDCl}_{3}, 400 \mathrm{MHz}\right),{ }^{13} \mathrm{C}\left\{{ }^{1} \mathrm{H}\right\} \quad \mathrm{NMR} \quad\left(\mathrm{CDCl}_{3}, \quad 101 \mathrm{MHz}\right)$ of $(\mathrm{IPr}) \mathrm{Pd}\left(\mathrm{OOCC}_{6} \mathrm{~F}_{5}\right)\left(\mathrm{CHPh}_{2}\right)$ (compound 2) 

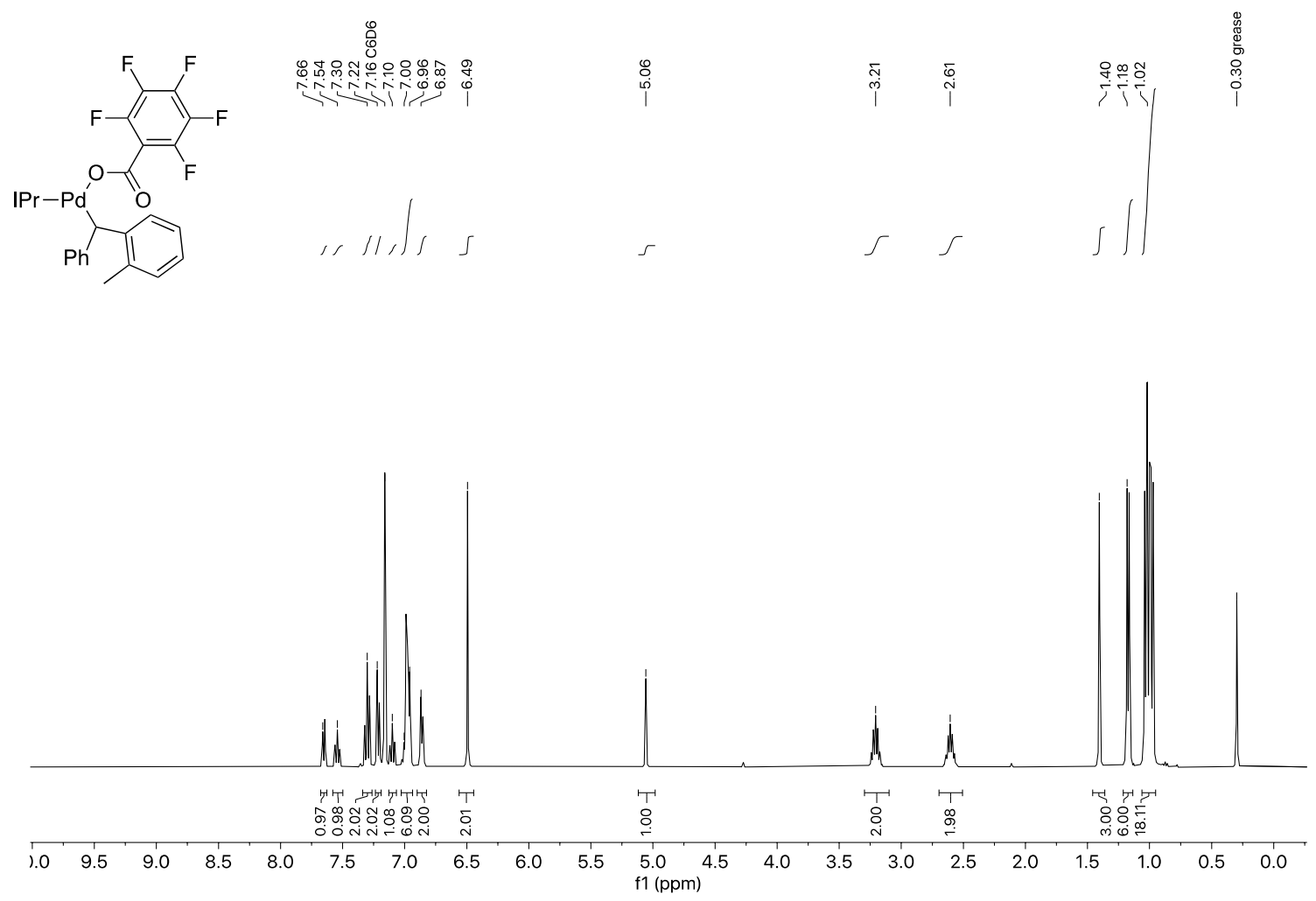

Figure S123: ${ }^{1} \mathrm{H} \mathrm{NMR}\left(\mathrm{CDCl}_{3}, 400 \mathrm{MHz}\right)$ of $(\mathrm{IPr}) \mathrm{Pd}\left(\mathrm{OOCC}_{6} \mathrm{~F}_{5}\right)(\mathrm{CH}(2-\mathrm{MePh}) \mathrm{Ph})$

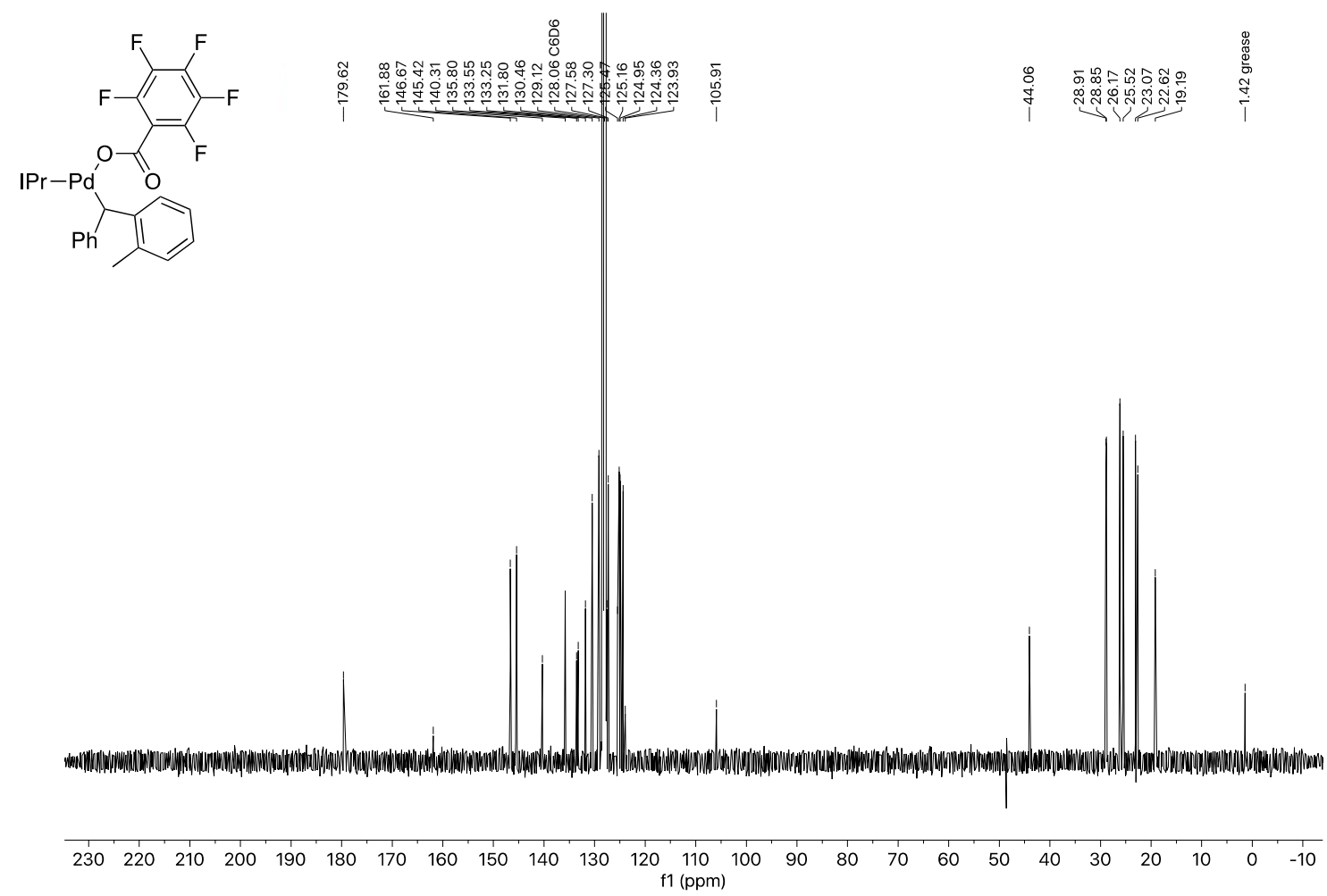

Figure S124: ${ }^{13} \mathrm{C}\left\{{ }^{1} \mathrm{H}\right\} \mathrm{NMR}\left(\mathrm{CDCl}_{3}, 101 \mathrm{MHz}\right)$ of $(\mathrm{IPr}) \mathrm{Pd}\left(\mathrm{OOCC}_{6} \mathrm{~F}_{5}\right)(\mathrm{CH}(2-\mathrm{MePh}) \mathrm{Ph})$ 

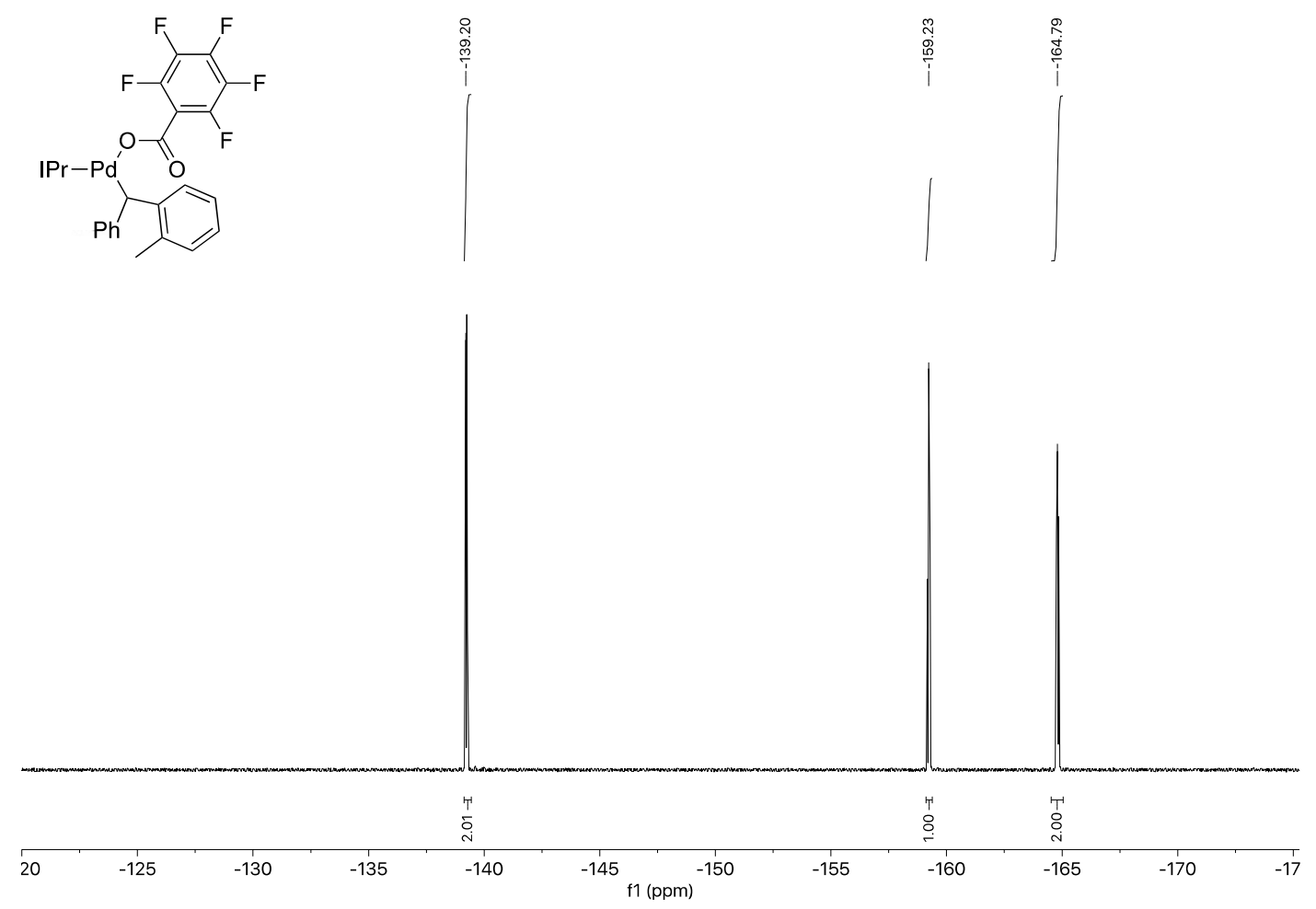

Figure S125: ${ }^{19} \mathrm{~F}$ NMR $\left(\mathrm{CDCl}_{3}, 376 \mathrm{MHz}\right)$ of $(\mathrm{IPr}) \mathrm{Pd}\left(\mathrm{OOCC}_{6} \mathrm{~F}_{5}\right)(\mathrm{CH}(2-\mathrm{MePh}) \mathrm{Ph})$ 


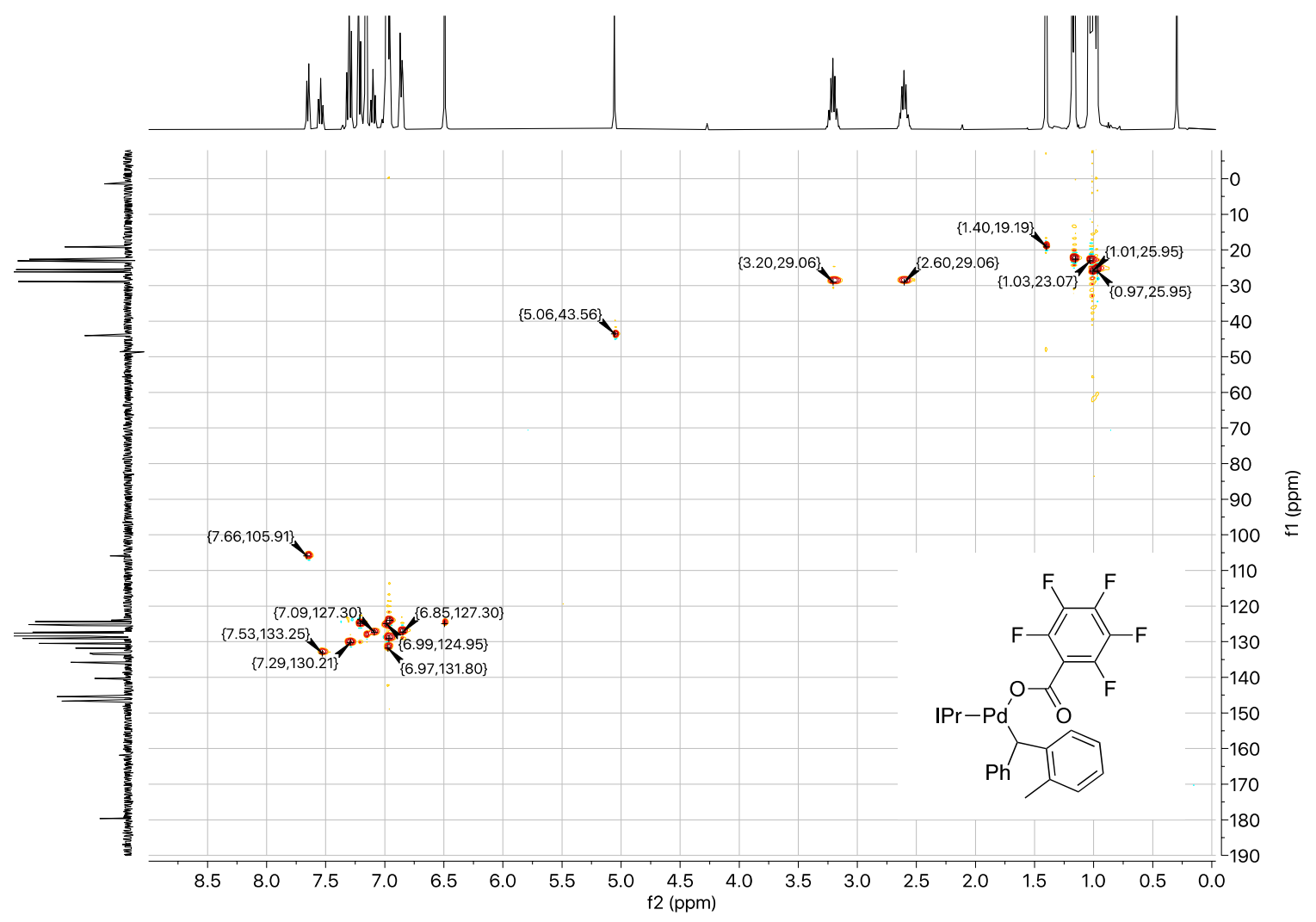

Figure S126: ${ }^{1} \mathrm{H} \quad \mathrm{NMR}\left(\mathrm{CDCl}_{3}, 400 \mathrm{MHz}\right),{ }^{13} \mathrm{C}\left\{{ }^{1} \mathrm{H}\right\} \quad \mathrm{NMR} \quad\left(\mathrm{CDCl}_{3}, 101 \mathrm{MHz}\right)$ of $(\mathrm{IPr}) \mathrm{Pd}\left(\mathrm{OOCC}_{6} \mathrm{~F}_{5}\right)(\mathrm{CH}(2-\mathrm{MePh}) \mathrm{Ph})$ 


\section{HPLC Data}

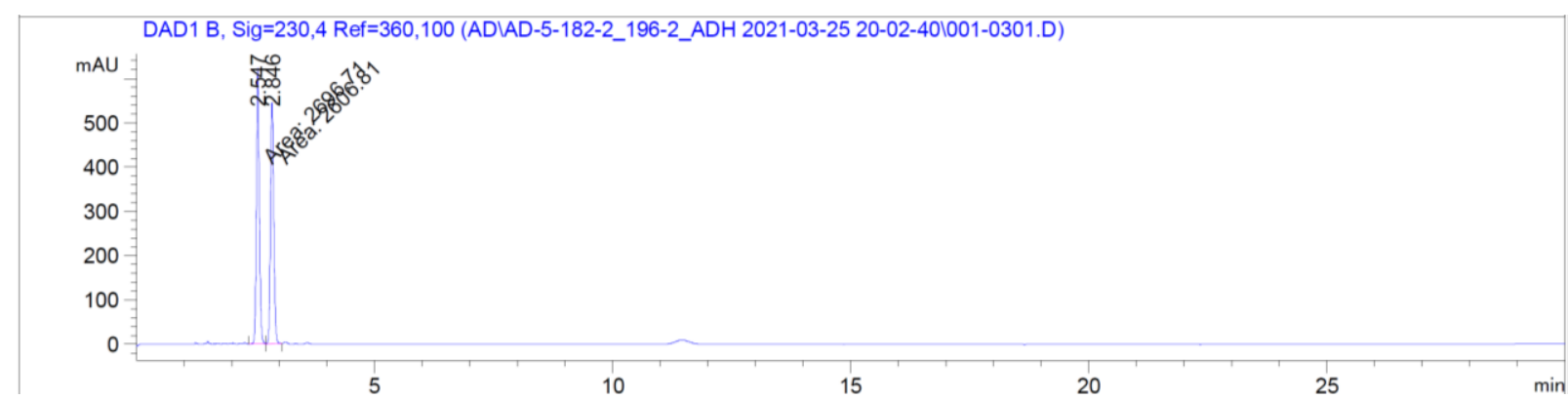

Figure S127: HPLC of racemic (2-naphthyl)(phenyl)methyl pentafluorobenzoate. Peaks appear at $2.547 \mathrm{~min}$ and $2.846 \mathrm{~min}$ with a relative area of $50.85 \%$ and $49.15 \%$ respectively.

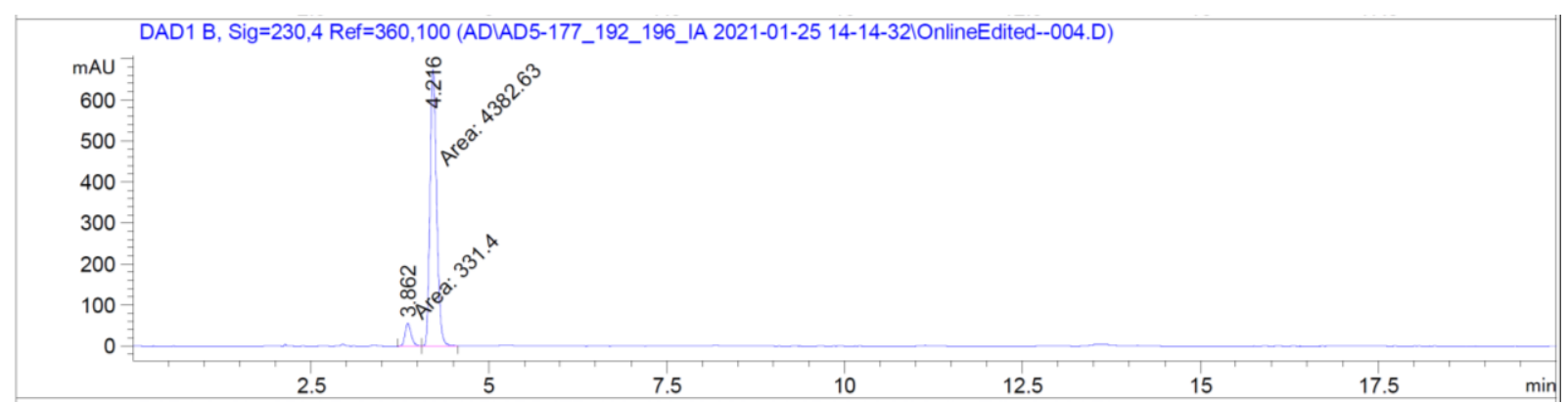

Figure S128: HPLC of (S)-(2-naphthyl)(phenyl)methyl pentafluorobenzoate. Peaks appear at $3.862 \mathrm{~min}$ and $4.216 \mathrm{~min}$ with a relative area of $7.03 \%$ and $92.97 \%$ respectively.

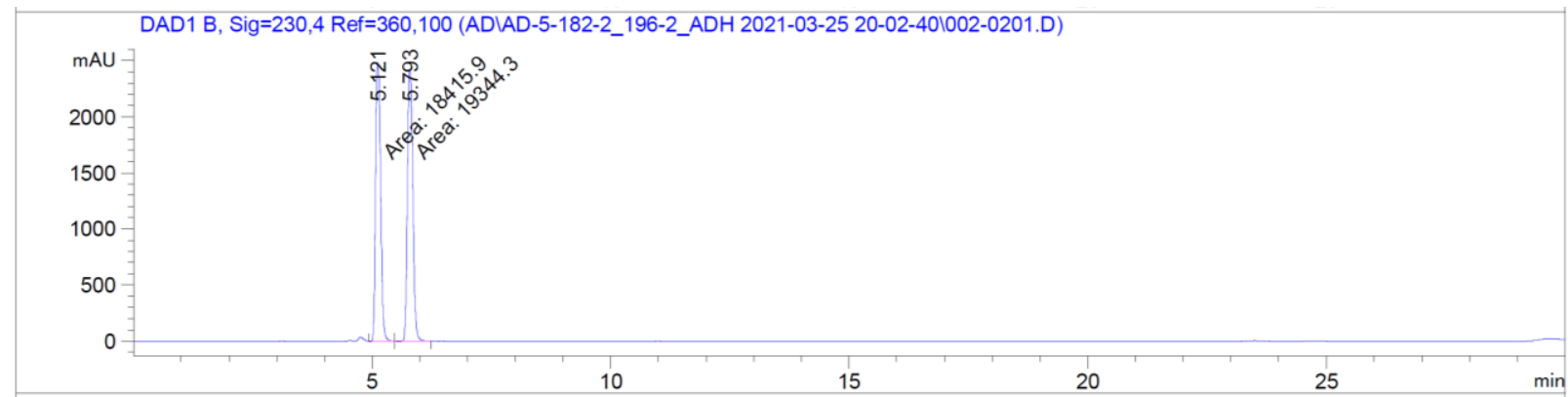

Figure S129: HPLC of racemic (3-furyl)(2-naphthyl)(phenyl) methane. Peaks appear at 5.121 min and 5.792 min with a relative area of $50.31 \%$ and $49.69 \%$ respectively.

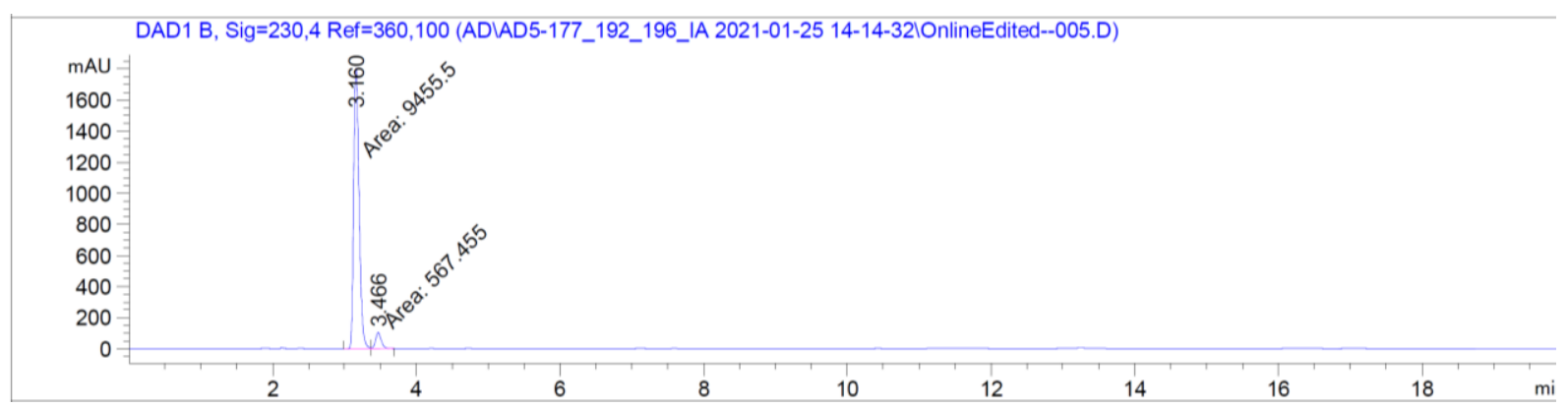

Figure S130: HPLC of (R)-(3-furyl)(2-naphthyl)(phenyl) methane (7a). Peaks appear at 3.160 min and 3.466 min with a relative area of $94.33 \%$ and $5.66 \%$ respectively. 


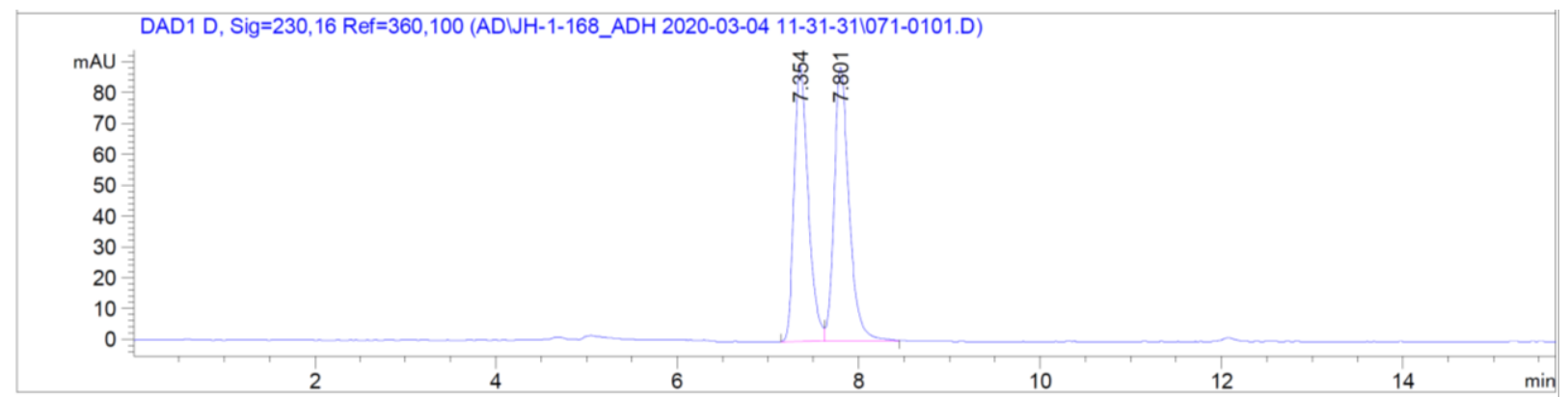

Figure S131: HPLC of racemic (4-methylphenyl)(phenyl)methyl pentafluorobenzoate. Peaks appear at $7.354 \mathrm{~min}$ and $7.801 \mathrm{~min}$ with a relative area of $48.68 \%$ and $51.32 \%$ respectively.

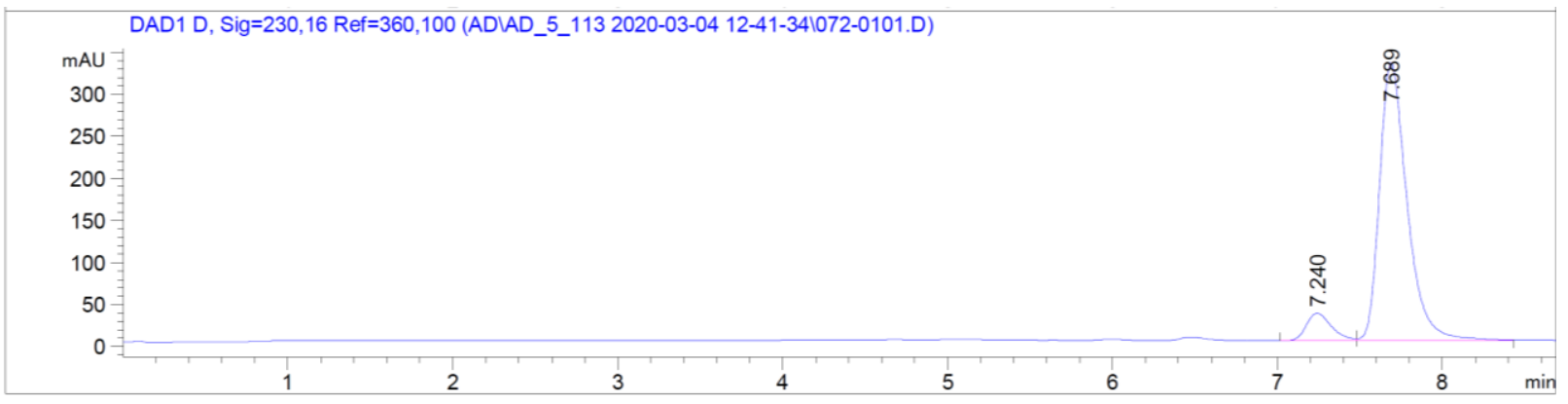

Figure S132: HPLC of (S)-(4-methylphenyl)(phenyl)methyl pentafluorobenzoate. Peaks appear at $7.240 \mathrm{~min}$ and $7.689 \mathrm{~min}$ with a relative area of $8.26 \%$ and $91.75 \%$ respectively.

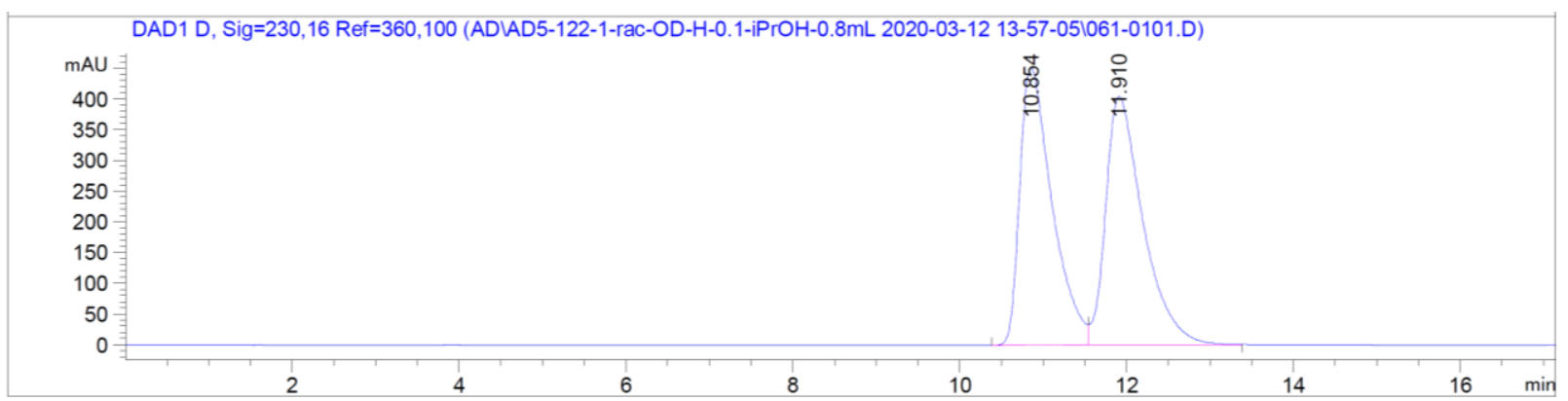

Figure S133: HPLC of racemic (4-methylphenyl)(4-methoxyphenyl)(phenyl) methane. Peaks appear at $10.854 \mathrm{~min}$ and $11.910 \mathrm{~min}$ with a relative area of $49.13 \%$ and $50.87 \%$ respectively.

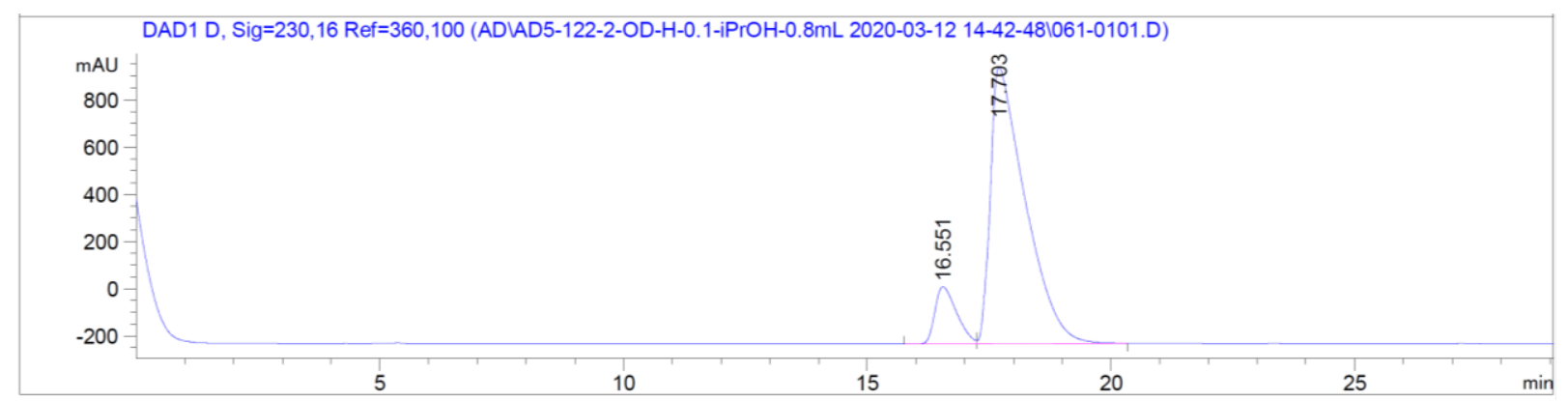

Figure S134: HPLC of $(R)$-(4-methylphenyl)(4-methoxyphenyl)(phenyl) methane (7b). Peaks appear at $16.551 \mathrm{~min}$ and $17.703 \mathrm{~min}$ with a relative area of $11.45 \%$ and $88.55 \%$ respectively. 


\section{References}

1. Tang, P.; Wang, W.; Ritter, T. Deoxyfluorination of Phenols. J. Am. Chem. Soc. 2011 133, $11482-11484$.

2. (a) Marion, N.; Navarro, O.; Mei, J.; Stevens, E. D.; Scott, N. M.; Nolan, S. P. Modified $(\mathrm{NHC}) \mathrm{Pd}($ allyl)Cl $(\mathrm{NHC}=\mathrm{N}-$ Heterocyclic Carbene) Complexes for Room-Temperature SuzukiMiyaura and Buchwald-Hartwig Reactions. J. Am. Chem. Soc. 2006, 128, 4101-4111; (b) Melvin, P. R.; Nova, A.; Balcells, D.; Dai, W.; Hazari, N.; Hruszkewycz, D. P.; Shah, H. P.; Tudge, M. T. Design of a Versatile and Improved Precatalyst Scaffold for Palladium-Catalyzed Cross-Coupling: $\left(\eta^{3}-1 \text { - }{ }^{\mathrm{B} u} \text {-indenyl }\right)_{2}(\mu-\mathrm{Cl})_{2} \mathrm{Pd}_{2}$. ACS Catal. 2015, 5, 3680-3688; (c) Adams, C. J.; Lusi, M.; Mutambi, E. M.; Orpen, A. G. Two-Step Solid-State Synthesis of PEPPSI-Type Compounds. Chem. Commun. 2015, 52, 9632-9635.

3. Harris, M. R.; Hanna, L. E.; Greene, M. A.; Moore, C. E.; Jarvo, E. R. Retention or Inversion in Stereospecific Nickel-Catalyzed Cross- Coupling of Benzylic Carbamates with Arylboronic Esters: Control of Absolute Stereochemistry with an Achiral Catalyst. J. Am. Chem. Soc. 2013, 135, 3303-3306.

4. Braga, A. L.; Paixão, M. W.; Westermann, B.; Schneider, P. H.; Wessjohann, L. A. Acceleration of Arylzinc Formation and Its Enantioselective Addition to Aldehydes by Microwave Irradiation and Aziridine-2-methanol Catalysts. J. Org. Chem. 2008, 73, 2879-2882.

5. Ben-Halima, T.; Zhang, W.; Yalaoui, I.; Hong, X.; Yang, Y.-F.; Houk, K. N.; Newman, S. G. Palladium-Catalyzed Suzuki-Miyaura Coupling of Aryl Esters. J. Am. Chem. Soc. 2017, 139, 1311-1318.

6. Harris, R. K.; Becker, E. D.; Menezes, S. M. C. D.; Granger, P.; Hoffman, R. E.; Zilm, K. W. Further Conventions for NMR Shielding and Chemical Shifts. Pure Appl. Chem. 2008, 80, 59-84. 7. Tsuji, H.; Hashimoto, K.; Kawatsura, M. Nickel-Catalyzed Benzylic Substitution of Benzyl Esters with Malonates as a Soft Carbon Nucleophile. Org. Lett. 2019, 21, 8837-8841.

8. Lai, M.; Wu, X.-F. Palladium-Catalyzed Carbonylative Synthesis of Benzyl Benzoates Employing Benzyl Formates as Both CO Surrogates and Benzyl Alcohol Sources. Eur. J. Org. Chem. 2019, 23, 3776-3778.

9. Xu, X.-L.; Li, Z. Catalytic Electrophilic Alkylation of $p$-Quinones through a Redox Chain Reaction. Angew. Chem. Int. Ed. 2017, 56, 8196-8200.

10. Matić, M.; Denegri, B.; Kronja, O. Method for Estimating $\mathrm{S}_{\mathrm{N}} 1$ Rate Constants: Solvolytic Reactivity of Benzoates. J. Org. Chem. 2012, 77, 8986-8998.

11. Lin, F. L.; Hoyt, H. M.; Halbeek, H. v.; Bergman, R. G.; Bertozzi, C. R. Mechanistic Investigation of the Staudinger Ligation. J. Am. Chem. Soc. 2005, 127, 2686-2695.

12. Nambo, M.; Crudden, C. M. Modular Synthesis of Triarylmethanes through PalladiumCatalyzed Sequential Arylation of Methyl Phenyl Sulfone. Angew. Chem. Int. Ed. 2014, 53, 742746.

13. Nambo, M.; Yim, J. C.-H.; Fowler, K. G.; Crudden, C. M. Synthesis of Tetraarylmethanes by the Triflic Acid-Promoted Formal Cross-Dehydrogenative Coupling of Triarylmethanes with Arenes. Synlett 2017, 28, 2936-2940.

14. Xia, Y.; Hu, F.; Liu, Z.; Qu, P.; Ge, R.; Ma, C.; Zhang, Y.; Wang, J. Palladium-Catalyzed Diarylmethyl C(sp3)-C(sp2) Bond Formation: A New Coupling Approach toward Triarylmethanes. Org. Lett. 2013, 15, 1784-1787.

15. Yu, J.-Y.; Kuwano, R. Suzuki-Miyaura Coupling of Diarylmethyl Carbonates with Arylboronic Acids: A New Access to Triarylmethanes. Org. Lett. 2008, 10, 973-976. 
16. Zhang, Z.; Wang, H.; Qiu, N.; Kong, Y.; Zeng, W.; Zhang, Y.; Zhao, J. Synthesis of Triarylmethanes via Palladium-Catalyzed Suzuki Coupling of Trimethylammonium Salts and Arylboronic Acids. J. Org. Chem. 2018, 83, 8710-8715.

17. Ji, X.; Huang, T.; Wu, W.; Liang, F.; Cao, S. LDA-Mediated Synthesis of Triarylmethanes by Arylation of Diarylmethanes with Fluoroarenes at Room Temperature. Org. Lett. 2015, 17, 50965099.

18. Masanori, W.; Hisashi, M.; Tetsuya, W.; Satoko, N.; Hideki, K.; Katsuhiko, K.; Shuichi, H.; Tatsuo, E. Triarylcarbenium Salts Highly Reducible by Primary Alcohols. Bull. Chem. Soc. Jpn. 1995, 68, 243-249.

19. Nambo, M.; Ariki, Z. T.; Canseco-Gonzalez, D.; Beattie, D. D.; Crudden, C. M. Arylative Desulfonation of Diarylmethyl Phenyl Sulfone with Arenes Catalyzed by Scandium Triflate. Org. Lett. 2016, 18, 2339-2342.

20. Martín, C.; Molina, F.; Alvarez, E.; Belderrain, T. R. Stable N-Heterocyclic Carbene (NHC)Palladium(0) Complexes as Active Catalysts for Olefin Cyclopropanation Reactions with Ethyl Diazoacetate. Chem. Eur. J. 2011, 17, 14885-14895.

21. Zhao, Y.; Truhlar, D. G. The M06 Suite of Density Functionals for Main Group Thermochemistry, Thermochemical Kinetics, Noncovalent Interactions, Excited States, and Transition Elements: Two New Functionals and Systematic Testing of Four M06-Class Functionals and 12 Other Functionals. Theor. Chem. Acc. 2008, 120, 215-241.

22. Grimme, S.; Antony, J.; Ehrlich, S.; Krieg, H. A Consistent and Accurate Ab Initio Parameterization of Density Functional Dispersion Correction (DFT-D) for the 94 Elements H-Pu. J. Chem. Phys. 2010, 132, 154104-154122.

23. (a) Weigend, F.; Ahlrichsb, R. Balanced Basis Sets of Split Valence, Triple Zeta Valence and Quadruple Zeta Valence Quality for H to Rn: Design and Assessment of Accuracy. Phys. Chem. Chem. Phys. 2005, 7, 3297-3305; (b) Weigend, F. Accurate Coulomb-fitting basis sets for $\mathrm{H}$ to Rn. Phys. Chem. Chem. Phys. 2006, 8, 1057-1065.

24. Marenich, A. V.; Cramer, C. J.; Truhlar, D. G. Universal Solvation Model Based on Solute Electron Density and a Continuum Model of the Solvent Defined by the Bulk Dielectric Constant and Atomic Surface Tensions. J. Phys. Chem. B. 2009, 113, 6378-6396.

25. Frisch, M. J.; Trucks, G. W.; Schlegel, H. B.; Scuseria, G. E.; Robb, M. A.; Cheeseman, J. R.; Scalmani, G.; Barone, V.; Petersson, G. A.; Nakatsuji, H.; X. Li, M. C.; Marenich, A.; Bloino, J.; Janesko, B. G.; Gomperts, R.; Mennucci, B.; Hratchian, H. P.; Ortiz, J. V.; Izmaylov, A. F.; Sonnenberg, J. L.; Williams-Young, D.; Ding, F.; Lipparini, F.; Egidi, F.; Goings, J.; Peng, B.; Petrone, A.; Henderson, T.; Ranasinghe, D.; Zakrzewski, V. G.; Gao, J.; Rega, N.; Zheng, G.; Liang, W.; Hada, M.; Ehara, M.; Toyota, K.; Fukuda, R.; Hasegawa, J.; Ishida, M.; Nakajima, T.; Honda, Y.; Kitao, O.; Nakai, H.; Vreven, T.; Throssell, K.; J. A. Montgomery, J.; Peralta, J. E.; Ogliaro, F.; Bearpark, M.; Heyd, J. J.; Brothers, E.; Kudin, K. N.; Staroverov, V. N.; Keith, T.; Kobayashi, R.; Normand, J.; Raghavachari, K.; A. Rendell; Burant, J. C.; Iyengar, S. S.; Tomasi, J.; Cossi, M.; Millam, J. M.; Klene, M.; Adamo, C.; Cammi, R.; Ochterski, J. W.; Martin, R. L.; Morokuma, K.; Farkas, O.; Foresman, J. B.; Fox, D. J. Gaussian, Inc., Wallingford CT, 2009. 